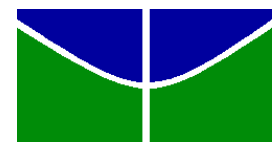

Universidade de Brasília - UnB

Centro de Excelência em Turismo - CET

Programa de Mestrado Profissional em Turismo - Cultura e Sustentabilidade

\title{
BRASÍLIA BUCÓLICA - A EXPERIÊNCIA DO CAMINHAR PELAS ENTREQUADRAS DE BRASÍLIA (CIDADE, ARTE E TURISMO)
}

DISSERTAÇÃO DE MESTRADO

Orientadora: Prof. ${ }^{a}$ Dr. ${ }^{a}$ Karina e Silva Dias

Mestranda: Tatiana Vieira Terra

Brasília, 2015 


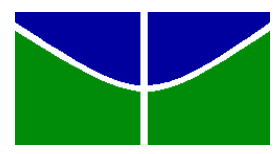

Universidade de Brasília - UnB

Centro de Excelência em Turismo - CET

Programa de Mestrado Profissional em Turismo - Cultura e Sustentabilidade

\section{BRASÍLIA BUCÓLICA - A EXPERIÊNCIA DO CAMINHAR PELAS ENTREQUADRAS DE BRASÍLIA (CIDADE, ARTE E TURISMO)}

TATIANA VIEIRA TERRA

Dissertação apresentada ao Programa de Pós-Graduação em Turismo da Universidade de Brasília como requisito para obtenção do título de Mestre.

Orientadora: Prof ${ }^{\mathrm{a}}$. Dr ${ }^{\mathrm{a}}$. Karina Silva e Dias

Brasília, 2015 
Ficha catalográfica elaborada pela Biblioteca Central da Universidade de Brasilia. Acervo 1020532.

Terra, Tatiana Vieira.

T323b Brasilia bucólica : a experiência do caminhar pelas entrequadras de Brasilia (cidade, arte e turismo) / Tatiana Vieira Terra. .. 2015. $134 \mathrm{f}$. : il. : $30 \mathrm{~cm}$.

Dissertaçăo (mestrado) - Universidade de Brasília, Centro de Excelência en Turismo. Programa de Mestrado Profissional em Turismo - Cultura e Sustentabilidade, 2015.

Orientação: Karina Si Iva e Dias.

Inclui bibliografia.

1. Tur ismo - Brasilia (DF). 2. Espaço (Arquitetura) - Brasilia (DF). 3. Desenho arquitetônico - Brasília (DF). 4. Paisagens - Brasilia (DF). 1. Dias, Karina e Silva. II. Título.

COU $338.482 .2(817.4)$ 


\section{Banca Examinadora}

Prof. ${ }^{a}$ Dr. ${ }^{a}$ Karina e Silva Dias

Orientadora

Universidade de Brasília - Unb

Prof. Dr. Luiz Carlos Spiller Pena

Membro Interno

Universidade de Brasília - UnB

Prof. ${ }^{\text {a }}$ Dr. ${ }^{\text {a Junia Marques Caldeira }}$

Membro externo

Centro Universitário de Brasília - UniCEUB

Prof. a Dr. ${ }^{a}$ Iara Lucia Gomes Brasileiro

Suplente

Universidade de Brasília - UnB 
Aos meus pais que me deram a vida 


\section{AGRADECIMENTOS}

Agradeço primeiramente aos meus pais e familiares, pela paciência, tolerância e apoio infinitos.

Aos irmãos de coração que comigo se envolveram no projeto, doando companhia, textos, livros, imagens, tempo, sorrisos e boas vibrações. São muito, mas não poderia de deixar de citar aqui Ana Beatriz Salles, Cinthia Carvalho, Marisa Tristan, Chun Kyong Kim, Ananda Tabosa de Córdova, Ramon Tabosa de Córdova, Alessandra Lalucce Adriana Veloso, Vanessa Pfeifer, Dulce Bergman, Juliana Bergman, Julio Pepe, Leo Sodré e Nicola Goretti.

Aos novos amigos que ganhei com esta experiência e aos amigos de sempre, entre

eles Ronaldo Neves Ferreira que me indicou a possibilidade desta experiência e Fernanda Martins pelo apoio em todos os sentidos e inabalável positividade

À Josy Almeida pelas parcerias, projetos e amizade e a Marcelo Moreno pelo auxílio na revisão dos textos, imagens fotográficas, disponibilidade e pela âncora nos momentos não devidos de sobrevôo. A Ulisses de Freitas Xavier pela sempre feliz presença e troca cultural.

À equipe do recreio, Fernando Sávio de Sousa, Antônio Joffily, Adriana Lima, Paula Hebling Dutra e Rodrigo Messias.

Ao SENAC, alunos e colegas professores pelos anos de aprendizagem.

Aos colegas do CET e de toda a UnB, Carolina Palhares, Thiago Gabriel Daher e Natália Heringer, Simone Spindola, Ana Paula Jacques, Lívia Barros Wiesinieski, Gabriel Marchioli e Paulo Honório Guimarães, Gabriel Galvão, Tamara Nicolau, Nádia Nunes, Alexander Malaver Copara, Erika Kilbert, Elias Mota, Maressa Rocha, Rogério Lacerda, Luís Eduardo Barros, Elvio e Maria Fernada Cavaton, Daniela Leite, Murilo Rocha, Alessandra Santos, Elissélia Ramos, Edemir Pulita, Rafael Oliveira, Luigi Polito e Marco Vermiglio, Samara Lima, Nayara Marques, Adriano Teles, Agatha Guerra, Bárbara Lins, Hugo Emanuel, Rogério Galeno e Fernanda, Magna Silva, Adriana Barroso Aguiar e todos os outros não citados, mas igualmente queridos, que fizeram desses últimos anos tempos mais divertidos.

À equipe do Brasília Bucólica por toda dedicação e criatividade.

Ao Vaga-Mundo, pelas inspirações de vida. 
À minha orientadora Karina Dias, que generosamente me propôs parceria na construção deste e demais projetos que surgiram no decorrer dos estudos, disponibilizou seu conhecimento, sua boa vontade, sua amizade, sempre com bom humor, delicadeza e carinho, em uma visível dedicação para esta conquista. À Karina Dias, toda a minha gratidão.

À Universidade de Brasília e ao Centro de Excelência em Turismo pela oportunidade de participar desta viagem deliciosa junto aos meus colegas e professores, todos especiais. À querida Marutschka Moesch pela dedicação sem igual, pelo conteúdo compartilhado, pelo carinho e presença em todos os momentos e pelos temperos dos risotos e do dia-a-dia. Ao professor Everaldo Costa pelos deleites intelectuais, pela dedicação, orientação e amizade. Ao diretor do CET, Neio Campos pela sua postura generosa e por toda simpatia. Aos professores Luiz Spiller, Iara Brasileiro e Junia Caldeira pelos sorrisos largos, contribuições acadêmicas e disponibilidade para composição da banca de defesa desta dissertação.

Aos que compreenderam minha ausência pela imersão na pesquisa e à minha sobrinha Beatriz Terra Resende que é flor de alegria. 


\section{RESUMO}

Bucólica Brasília - a experiência do caminhar pelas Entrequadras de Brasília é uma dissertação que investiga o caminhar na cidade de Brasília como possibilidade de transformar as relações habituais com os espaços da cidade que habitamos. Tem como ponto de partida as Escalas Bucólica e Residencial para análise das principais características do plano urbanístico de Lucio Costa, cuja vontade era criar o Plano Piloto de Brasília (Plano Piloto) como um espaço social destinado à população que nela habitaria, o conteúdo textual explora então a concepção da cidade de Brasília como forma de pensamento ético. Este pensamento inclui os habitantes e os convida a tomar posse da imensidão da cidade compartilhando seus espaços. Aqui tem-se Brasília para além do simples postal, porque é um espaço mutável, de descobertas contínuas e que pode ser percorrida por seus moradores ou aqueles que estão de passagem. A partir das bases teóricas sobre o Turismo e suas relações com a fenomenologia, a reflexão se desenvolve em diferentes noções sobre o espaço, a paisagem e a caminhada. A pesquisa considera o cidadão como turista em potencial, ou seja, um viajante em sua própria cidade. Bucólica Brasília - a experiência do caminhar pelas Entrequadras de Brasília se divide em quatro capítulos: Partida, Espaço Traçado, Espaço Percorrido e Em trânsito. Na partida são apresentadas a metodologia de pesquisa e as teorias sobre o Turismo; no segundo capítulo, Espaço Traçado, a pesquia analisa o desenho de Brasília e cidades de origem portuguesa no Brasil, a parir de suas escalas; o terceiro capítulo, Espaço Percorrido, explora as teorias da caminhada e desenvolve uma análise sobre o Projeto Brasília Bucólica, esta parte prática da teoria fenomenológica sobre o espaço aqui estudado. A última parte, Em trânsito, conclui a presente pesquisa.

Palavras-chave : Turismo, Brasília, Escala Bucólica e Residencial, Caminhar 


\section{RÉSUMÉ}

Brasília Bucólica - a experiência do caminhar pelas Entrequadras de Brasília (Brasília Bucolique - l'expérience de la promenade dans les Superquadras de Brasília) est une dissertation qui explore la marche (promenade) dans la ville de Brasilia comme une des possibilités de transformer nos relations habituelles avec les espaces de la ville où nous habitons. Ayant comme point de départ les Escales Bucólica et Residencial pour analyser les principaux caractéristiques du plan de l'urbaniste Lucio Costa, dont la volonté a été de créer le Plano Piloto de Brasília (Plan Pilote) comme un espace social destinée à la population qui y habiterait, ce texte explore, alors, la conception de la ville de Brasília comme une forme de pensée éthique. Cette pensée inclut les habitants, les invitent à prendre possession de l'immensité de la ville. Ceci passe par les liens que les habitants et les visiteurs tissent avec les espaces et de part leurs usages. Ici, Brasilia dépasse la simple carte postale parce qu'elle est un espace mutable, un espace de découvertes continu, prêtà être parcouru par ceux qu'y habitent ou par ceux quiy sont de passage. À partir des bases de théories du tourisme et leurs rapports avec la phénoménologie, une réflexion se développe sur les différentes notions d'espace, du paysage et de la marche comme promenade. Cette recherche comprend le touriste comme un citoyen/touristeen potentiel, c'est-à-dire, un voyageur dans sa propre ville. Brasília Bucólica - a experiência do caminhar pelas Entrequadras de Brasília (Brasília Bucolique - l'expérience de la marche (promenade) dans les Entrequadras de Brasília) se divise en quatre chapitres: Le départ, L'espace tracé, L'espace parcouru et En transite. Dans Le départ sont présentés la méthodologie de recherche ainsi que les théories sur le Tourisme; le second chapitre - L'espace tracé-, où l'on analyse le dessin de Brasília ainsi que d'autres villes d'origine portugaise au Brésil à partir de leurs Escalas; le troisième chapitre, L'espace parcouru, explore les théories de la marche (promenade) et dévéloppe une analyse sur le Projet Brasília Bucolique, ce dernier étant le versant pratique de la théorie phénoménologique de l'espace ici étudié. La dernière partie, En transite, conclu la présente recherche.

Mots-Clés: Tourisme, Brasilia, Escales Bucólica et Residencial, Marcher 
SUMÁRIO

INTRODUÇÃO

I - PARTIDA

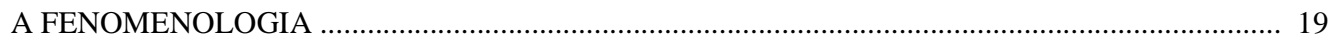

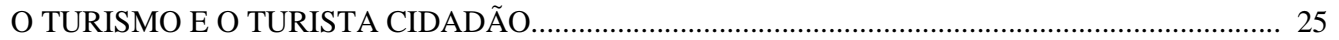

II - ESPAÇO TRAÇADO

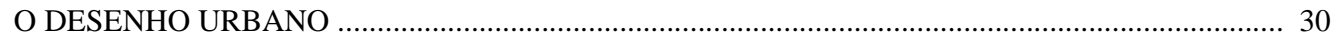

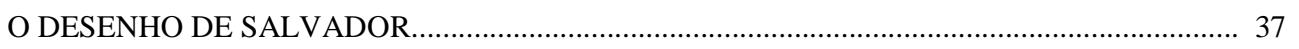

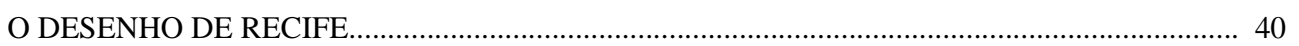

O DESENHO URBANO: BRASÍLIA ………................................................................................ 44

AS ESCALAS BUCÓLICA E RESIDENCIAL DE BRASÍLIA ........................................................... 54

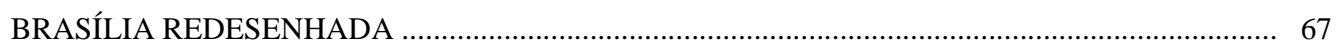

III- ESPAÇO PERCORRIDO

CAMINHAR, UMA OCUPAÇÃO EM MOVIMENTO …….......................................................... 87

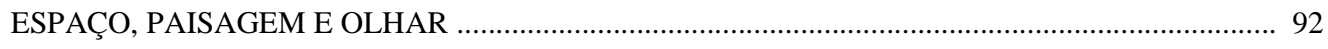

PROJETO BRASÍLIA BUCÓLICA - A EXPERIÊNCIA DO CAMINHAR .................................... 104

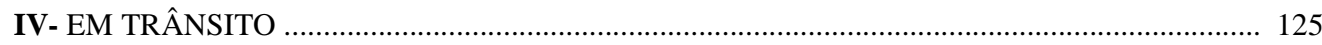

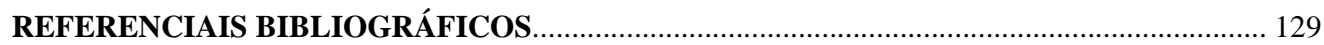

ANEXOS

ANEXO I - Lei 10.829, de 14 de outubro de 1987/ GDF

ANEXO II - Brasília Revisitada 


\section{I - INTRODUÇÃO}

O presente trabalho apresenta a investigação dos espaços da cidade sob a perspectiva de quem caminha e percebe o ambiente ao explorá-lo, como turista ou mesmo morador. O recorte da pesquisa se dá em duas Escalas da cidade de Brasília ${ }^{1}$. É uma proposta de conhecimento da cidade para além da visitação dos monumentos, pois ela é também significativa por seus espaços urbanos e por estes pode-se despertar o sensível no habitante e/ou visitante. Para o turista, uma alternativa de roteiro, e para o morador a possibilidade de se converter em turista na sua própria cidade.

Esta dissertação tem por base o conceito de Turismo como um fenômeno que transcende o determinismo econômico, como um processo que vai além das "relações de consumo/mercado e que abrange as necessidades, anseios e desejos humanos" (NETTO, 2011), uma investigação que contempla, portanto, o estudo das razões essenciais e do significado transcendente do turismo, tendo o foco nas pessoas e não apenas sob a perspectiva da sociedade de consumo. Visa a compreensão do espaço da cidade pela experiência ativa do turista, por sua vivência do espaço, proporcionada pela percepção ao caminhar. Considerando aquele que transita pela cidade enquanto visitante ou morador, trazemos a ideia do turista cidadão (GASTAL \& MOESCH, 2006), um conceito que será abordado para compor a teoria a ser desenvolvida.

Como metodologia de investigação, a fenomenologia é o instrumento escolhido, pois tem como qualidade primordial a percepção dos sentidos na articulação do sensível. A pesquisa é qualitativa, pois considera a qualidade e não a quantidade dos dados analisados. Foi formulada em um espaço de mobilidade das ideias, que organicamente foram se moldando no desenrolar dos estudos bem como alteradas quando necessário, aproximando a escrita ao traçar de um itinerário. É um estudo de

\footnotetext{
${ }^{1}$ Para esta dissertação compreendemos Brasília enquanto Plano Piloto que de acordo com o Capítulo I, Art. $1^{\circ}$ do Decreto $\mathrm{n}^{\circ}$ 10.829, de 14 de outubro de 1987/GDF regulamenta a Lei $\mathrm{n}^{\circ} 3.751$, de abril de 1960 e entende por Plano Piloto de Brasília a concepção urbana da cidade, conforme definida na planta em escala 1/20.000 e no Memorial Descritivo e respectivas ilustrações que constituem o projeto de autoria do Arquiteto Lucio Costa, escolhido como vencedor pelo júri internacional do concurso para a construção da nova Capital do Brasil. Fonte: Plano Piloto 50 anos: cartilha de preservação - Brasília. IPHAN, 2007.
} 
caso sobre a cidade de Brasília e se utiliza de teorias sobre a paisagem, a percepção da cidade e o caminhar, alinhadas às propostas do urbanista Lucio Costa para criação da cidade, focando o estudo em duas das quatro escalas que traduzem a concepção de Capital Federal, as Escalas Residencial e Bucólica, exemplificadas pela análise das superquadras residenciais. Apresenta uma breve introdução sobre o pensamento e o planejamento da criação das cidades sob a perspectiva do desenho para posterior entendimento do traço para o plano de Brasília.

Como objetivo geral, a pesquisa investigou de que forma a experiência do caminhar desvela a cidade de Brasília $^{2}$, com base teórica sobre o espaço, o corpo no espaço, a percepção da cidade e o próprio caminhar. Na prática, a pesquisa traz o Projeto Brasília Bucólica - a experiência do caminhar ${ }^{3}$ como resposta à teoria desenvolvida com alunos do curso de Turismo da Universidade de Brasília e comunidade, onde foram estabelecidas as relações entre a cidade e as formas de experimentar seus espaços, bem como a promoção das experiências possíveis não só para o turista convencional, mas também para o morador, no intuito de abordar o valor humanístico e cultural da cidade, previamente considerados no plano para sua construção e analisar a relevância do caminhar, particularmente nas superquadras. Uma abordagem de pesquisa que busca apresentar a cidade como possibilidade, aos seus visitantes e moradores, de descobertas e desdobramentos sensíveis. A questão de pesquisa que se apresenta é saber como a experiência do caminhar aproxima os habitantes/turistas da cidade, apurando o olhar e compreendendo a cidade para além do cartão postal, visto que iconograficamente a cidade é reconhecida por seus monumentos arquitetônicos, situados em sua maioria na Escala Monumental e, portanto sendo esta a escala da sua representatividade ${ }^{4}$, até então.

\footnotetext{
${ }^{2}$ Brasília é uma das trinta Regiões Administrativas do Distrito Federal. É enumerada como RA I dentre os núcleos urbanos do Distrito Federal: Região Administrativa de Brasília (RA I - Brasília).

${ }^{3}$ O Projeto Brasília Bucólica - a experiência do caminhar foi desenvolvido para estimular novas percepções da cidade e suas múltiplas abordagens com foco na experiência do caminhar pela escala residencial e bucólica de Brasília. Ver o capítulo III - Espaço Percorrido, desta dissertação.

${ }^{4}$ Imagens retiradas do Google na pesquisa por "Brasília" de 12/01/2015. Das trinta primeiras imagens, que aparecem vinte e seis são da Escala Monumental, onde a imagem do Congresso Nacional figura como principal imagem representativa da cidade de Brasília.
} 
Figura 01: Iconografias de Brasília
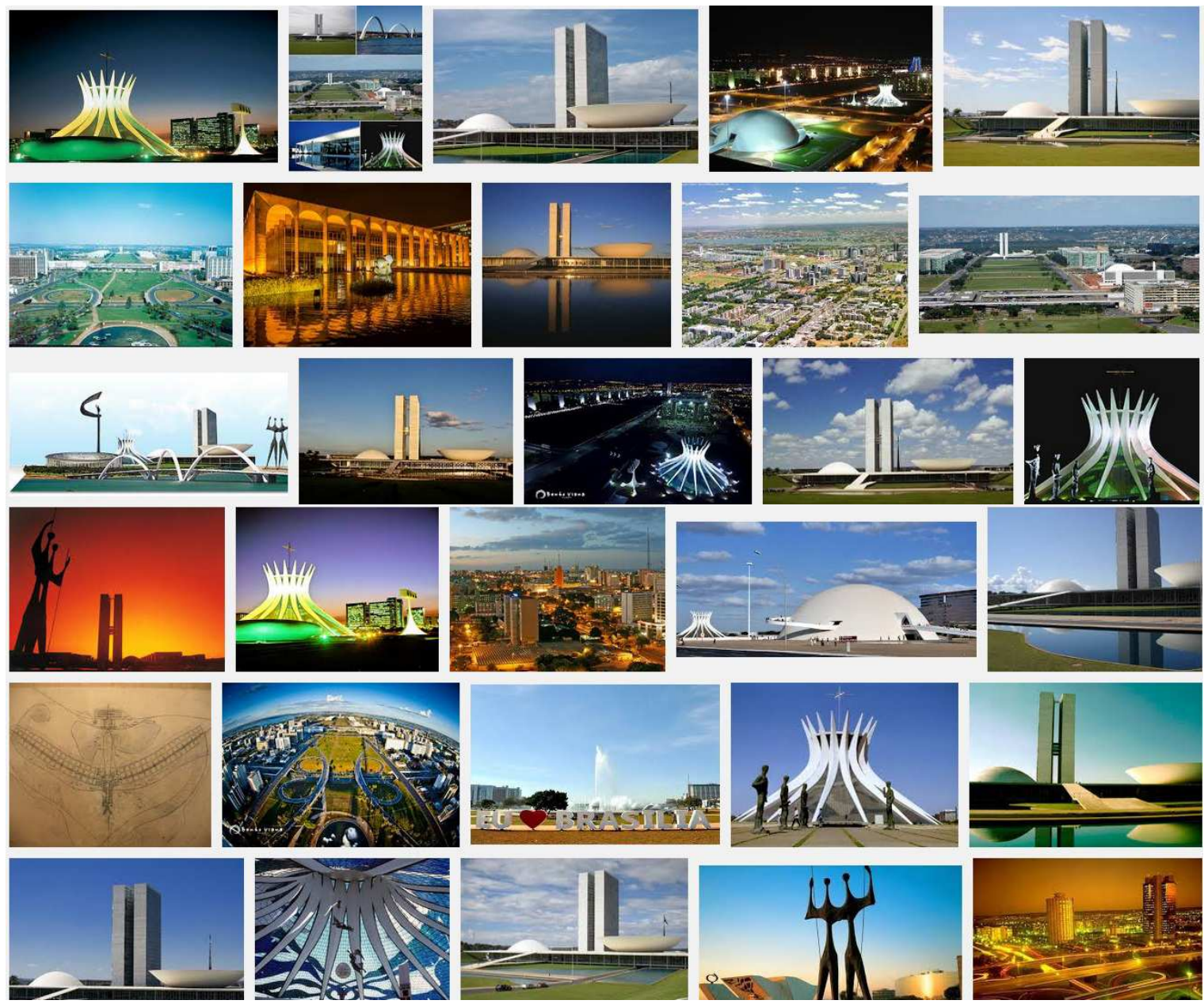

Fonte: Google (2014)

Esta pesquisa propõe o deslocamento desta representação, que consequentemente figura em catálogos, folders, congressos, painéis, etc. quando informação associada à cidade e que ilustram também Brasília na área turística ${ }^{5}$, conforme imagens abaixo:

\footnotetext{
${ }^{5}$ Imagens disponíveis na internet (01/2015), onde aparecem as imagens dos monumentos arquitetônicos como referência à cidade de Brasília in

https://www.google.com.br/search?q=bras\%C3\%ADlia\&es_sm=93\&source=lnms\&tbm=isch\&sa=X\&ei= -_roVPSEBsW1ggTO14TgDw\&ved=0CAgQ_AUoAg\&biw=1360\&bih=643
} 
Figuras 02: Imagens que fazem referência à Brasília
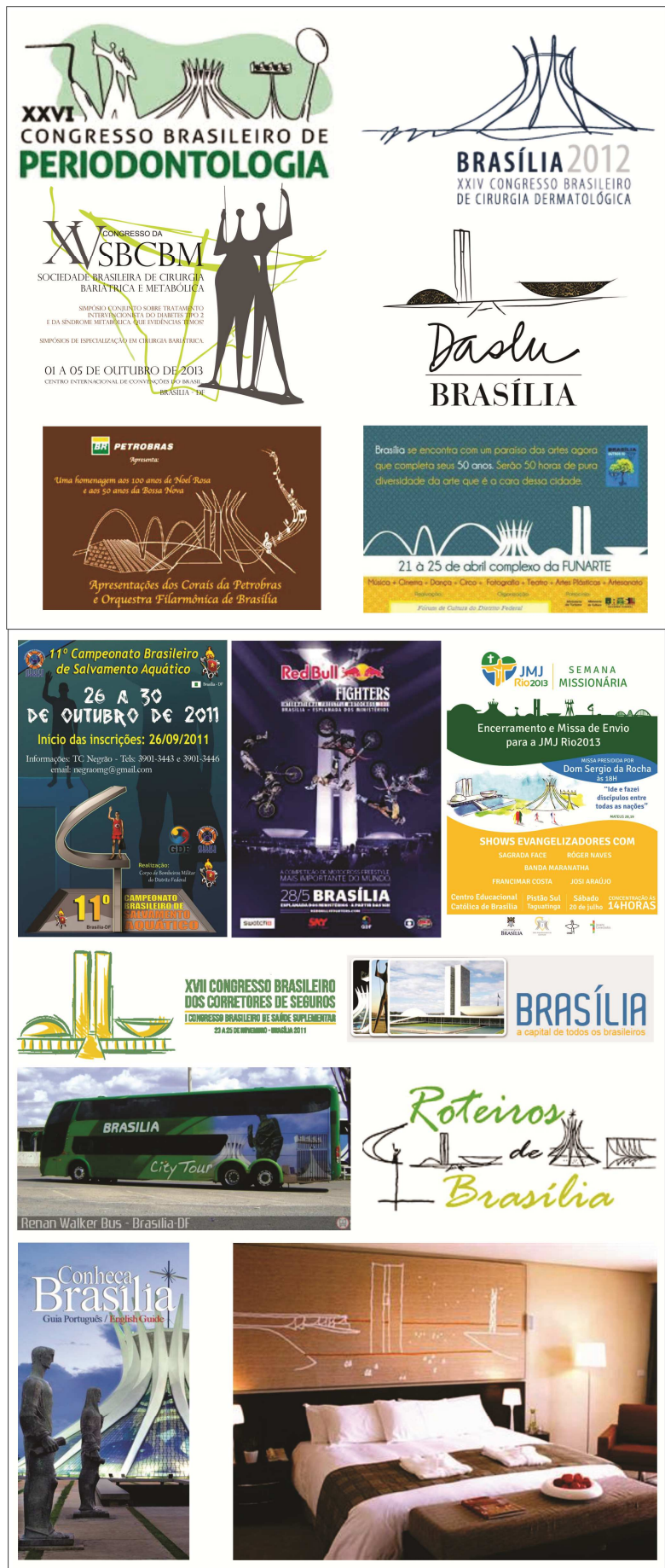

Fonte: Google (2014)

A escolha do tema para esta investigação se deve ao fato da minha proximidade com o trabalho de formação de guias de turismo ${ }^{6}$. Percebe-se que,

\footnotetext{
${ }^{6}$ Trabalho que começa no ano 2000 no Serviço Nacional de Aprendizagem Comercial - SENAC/ DF na área de Turismo e Hospitalidade e se estende até hoje (janeiro/2015). No curso os alunos, apresentam, em
} 
direcionada ao mercado de trabalho, a formação de futuros profissionais de guia de turismo tem como base os preceitos do Turismo que o determinam como um negócio econômico, onde as técnicas são acima de tudo racionalizadas e sistematizadas para cumprimento de uma tarefa. Nesse sentido há uma programação onde os organizadores de um passeio, uma viagem ou uma jornada, seja no campo, na cidade, ou numa praia, esboçam um tempo fragmentado de visitação para o "conhecimento" de uma rota estabelecida, que impede maior proximidade e condições sensíveis de experimentação, ações próprias das agências de viagem, passeios e city tours. Tendo como formação o campo artístico e compreendendo que os espaços podem ser vivenciados e os lugares percebidos e assim compreendidos de forma única e diferenciada, o intuito da pesquisa foi buscar ultrapassar as noções restritas sobre o que se "vê", e se "conhece", no campo do Turismo, onde ainda predominam os roteiros tradicionais, quando não repetitivos, das imagens formadas e reproduzidas do senso comum. São movimentos que aos moldes de Tamara ${ }^{7}$, visitada por Marco Polo, predispõe um

olhar (que) percorre as ruas como se fossem páginas escritas: a cidade diz tudo o que você deve pensar, faz você repetir o discurso, e, enquanto você acredita estar visitando Tamara, não faz nada além de registrar nomes com os quais ela define a si própria e todas as suas partes (CALVINO, 1990).

Afirma Calvino (1990) que "a memória é redundante: repete os símbolos para que a cidade comece a existir", o que reforça o uso de imagens padronizadas para o seu (re)conhecimento e uso nos mais diversos campos sociais onde ela pode ser matéria, inclusive negociada.

No entanto, trazer a cidade de Brasília explorada fora do convencional é investigar outras e novas relações entre o homem e os espaços vivenciados, associada pela experiência do caminhar. Julgando hoje ser a caminhada um método de desaceleração, em face da enorme urgência de tudo em um mundo vertiginoso, ela vem, então, como instrumento de uma possível compreensão sensível para percepções diferenciadas do espaço percorrido, para melhor leitura das páginas da cidade. A caminhada tornou-se o meio escolhido para a experimentação do espaço nesta pesquisa.

sua maioria, ideais de roteiros e itinerários para as saídas técnicas em função da demanda do mercado, muitas vezes sem imaginar que podem existir outras possibilidades de visitação e apresentação de uma localidade que não seja aquela determinada pelo Trade turístico.

${ }^{7}$ Tamara é uma das cidades apresentadas por Ítalo Calvino in Cidades Invisíveis, 1990. 
E o espaço escolhido, a cidade de Brasília em duas das suas quatro escalas, a Escala Residencial e a Escala Bucólica, que permeia a Residencial.

As Escalas Monumental e Gregária não são contempladas no estudo visto que, é na Escala Monumental que se encontram as principais edificações arquitetônicas que formam as iconografias popularmente conhecidas da cidade, ou seja, as imagens que a fazem conhecer e permeiam os cartões postais e recortes difundidos pelos meios de comunicação e por grande parte das empresas de turismo. A pesquisa buscou justamente distanciar-se da ideia da cidade exposta pelos cartões postais no intuito de apresentá-la por outros locais e por outro viés: pela contemplação da Escala Bucólica, caminhando pela Escala Residencial. A Escala Gregária também não foi apreciada para esta pesquisa por constituir uma área destinada às atividades de trabalho, ainda que apresente interessantes pontos de cultura e diversão, teatros, museus, galerias e casas de shows que flexibilizam a dinâmica laboral ali concentrada. Sendo assim, foi feita a escolha da Escala Bucólica (que permeia praticamente toda a cidade) com recorte concentrado na Escala Residencial.

Esta não é uma investigação que deseja questionar se a cidade é ou não uma cidade para pedestres e sim propor um novo olhar sobre a cidade e sua condição de acolhida ao pedestre em sua Escala Residencial/Bucólica, pois são estas as extensões cujo plano urbanístico contempla calçadas e áreas verdes, áreas abertas, jardins e pilotis em uma grande área determinada para as residências da cidade, ponto de partida do morador para o trabalho, para o comércio e para o lazer.

As quadras residenciais de Brasília são modelos de habitação únicos que devem ser conhecidos e experimentados, não só por sua proposta inovadora, mas também pela possibilidade de vivência e percepção. Experiência que pode ser ampliada aos visitantes da cidade pela experiência do caminhar. Desta forma consideramos os objetivos da pesquisa como o de se estabelecer relações entre a cidade de Brasília e as maneiras de experimentar seus espaços assim como a promoção destas experiências não só para o turista convencional, mas também para o morador da cidade; abordar o valor humanístico e cultural da cidade de Brasília, previamente considerados no Plano aprovado para sua construção e investigar a relevância do caminhar pela cidade como experiência exploratória, especialmente em suas Superquadras, para apresentá-la como 
possibilidade de descobertas e desdobramentos sensíveis aos seus visitantes e moradores.

Por que a cidade de Brasília? Brasília surge de um planejamento ímpar, ainda que proveniente de muitas inspirações e se estabelece como contraponto ao caos urbano das grandes cidades. Nascida no país cuja a tradição das construções das cidades não cedeu às imposições de um plano racionalista criado além-mar em suas primeiras investidas e que adaptou suas formas urbanas à topografia, bem como usou da influencia das organizações sociais indígenas e inspirações trazidas nas formas medievais de cidades portuguesas nos seus primórdios, situa-se hoje como um contraste diante as atuais cidades globalizadas, que tendem a ser iguais, crescem desordenadamente e convertem-se em espaços caóticos e incivilizados. Brasília foi pensada por seu criador Lucio Costa como um "organismo capaz de preencher satisfatoriamente as funções vitais próprias de uma cidade moderna qualquer, não apenas como urbs, mas como civitas" $^{\prime 8}$ (COSTA, 1957), ou seja, além de desenhada para ser a capital administrativa do Brasil foi pensada para ser local cômodo e acolhedor. Seu plano urbanístico original valoriza o ser humano, privilegia a conexão do espaço com o corpo e proporciona a vivência de práticas mais humanas por visitantes e moradores, onde "o homem é respeitado em seu 'habitar', sem se perder num labirinto administrativo ou se perder numa rede de comunicações"9. Segundo Sennett (1994), cidades que desconsideram a liberdade de movimento e não permitem ao ser humano obter percepções e sensações corporais saudáveis em relação a elas, são cidades "fragmentadas e excludentes". Podemos especular em Brasília condições contrárias em relação ao seu habitante. Brasília responde ao ideal do seu idealizador humanista, mas ainda é uma cidade incompreendida por muitos, principalmente por aqueles que estão à parte, distantes, seja pela imagem que é difundida pelos meios de comunicação, seja pela forma automatizada que algumas empresas de turismo apresentam a cidade hoje. Uma cidade para ser conhecida, precisa ser vivenciada, ainda mais quando ela se apresenta como novidade, tão particular e única. Uma cidade para entendê-la, precisa-se de um "tempo de digestão".

\footnotetext{
${ }^{8}$ Projeto de Lucio Costa disponível no site do IPHAN http://portal.iphan.gov.br/portal/baixaFcdAnexo.do?id=280

${ }^{9}$ Declaração de Stamo Papadaki, membro da comissão julgadora para escolha do Plano Piloto de Brasília, disponível no livro O Concurso de Brasília, de Milton Braga, 2010.Pg185
} 
Observa-se que muitos daqueles que vivem em Brasília percebem o processo desumano a que tendem as grandes cidades, e criam nela movimentos de resistência e fortalecimento de sua essência. Hoje, filhos dessa cidade, ainda muito nova (55 anos), respondem ao projeto do seu idealizador, organizando movimentos de ocupação de seus espaços para o lazer, abertos a turistas e moradores. São casos de reconhecimento de sua natureza e que a cada ano crescem em número e diversidade temática. Como exemplo, o "Picnik no Calçadão", um misto de mercadinho descolado e sunset party ${ }^{10}$, que mistura arte, moda, música, o dia, festa, bazar, sorrisos: de graça! ${ }^{11}$ Com mais de 18000 curtidas em sua página no Facebook ${ }^{12}$, conseguiu, em suas últimas versões, reunir um público de mais de dez mil pessoas para um encontro de desfrute dos espaços bucólicos que a cidade oferece (ver capítulo Brasília Redesenhada). Um exemplo que fortalece o conceito do uso do espaço público, proporcionado pela Escala Bucólica, uma das mais sensíveis dentre as quatro escalas idealizadas na concepção urbanística e, portanto, contemplada nesta pesquisa. É esta a escala que contempla um lago que abraça a cidade, frondosas árvores que protegem as edificações do som e do sol e um céu que nos traz uma visão de $180^{\circ}$ de horizonte, um céu que como as frondosas árvores criam uma atmosfera de conforto, silêncio e acolhimento. Acima o céu, "mar de Brasília" (COSTA, 1987), espaço contemplado pelo traço da cidade, um teto possível de uma casa sem paredes, portas ou janelas, livre, aberta, espaçosa, que a princípio estaria disponível a todos. Abaixo, o espaço traçado, onde possibilitar a caminhada e construções de percursos livres é uma representação viva do direito de ir e vir (e de sentir-se) de todo cidadão. Esta investigação é uma proposta de encontro do caminhante com o espaço, para melhor compreensão do mesmo em busca de um novo retrato da cidade que não pode ser vista e reconhecida unicamente por seus monumentos. A cidade possui arquitetura admirável e emergiu sobre um plano generoso. Por sua arquitetura, é conhecida mundialmente, no entanto, sua magnitude é viabilizada pelo projeto urbanístico de Lucio Costa que generosamente evidencia e engrandece o que nele se apoia. É assim com a arquitetura, é assim com o ser humano habitante e visitante da cidade.

\footnotetext{
${ }^{10}$ Evento que se utiliza dos espaços livres e abertos para contemplação do pôr-do-sol.

${ }^{11}$ Informação disponível em: https://www.facebook.com/home.php\#!/PicnikNoCalcadao/info. Acesso em: 01/07/2014. Miguel Galvão. Brasília, 21 de abril de 2012.

${ }^{12}$ São 18.062 curtidas registradas até a data de 12/01/2015
} 


\section{I - PARTIDA}

\section{A FENOMENOLOGIA}

A percepção é a qualidade essencial considerada pelo método fenomenológico de pesquisa. Para Merleau-Ponty, a percepção e o mundo das operações lingüísticas encontram-se em uma trama, uma configuração, uma ordem, que se prolonga na dimensão dos atos expressivos, esta trama é a trama e articulação do sensível, onde o que é percebido não se dá nunca em si mesmo, mas em um contexto relacional, dotado de um horizonte interno e externo, como uma figura sobre fundo (MERLEAU-PONTY apud BONOMI, 1974). Assim, no mundo perceptivo, observar um objeto fechado em si mesmo é assumir uma posição preconceituosa e objetivista, ou seja, a própria posição dos modelos deterministas. Para Didi-Huberman (1998) essa é uma postura tautológica: observar o objeto em si, sem a presença latente, sem a análise do que está além da lógica da visão. É permanecer no campo das objetividades sem perceber os reflexos, as sombras, os níveis e os horizontes entre as coisas.

Segundo Bonomi (1974), em uma reflexão fenomenológica, o sentido das coisas está entre os signos, e não neles, não é aderente ou uma propriedade permanente, está na multiplicidade de significantes que, por sua vez, não é o suporte do significado. Se assim fosse, as relações conceituais estariam no campo das exterioridades e do empirismo. Desta forma, o sentido das coisas deve ser buscado ao "lado do sujeito agente e concreto - no tecido das relações inter-humanas (onde) a intersubjetividade torna-se ponto de referência".

A intersubjetividade é a proposta apresentada por Merleau-Ponty para o campo das inter-relações que considera o subjetivo e o transcendental, e posiciona o sujeito em uma experiência do sensível, que traz à luz o estrato originário em que a corporeidade, como práxis intencional, serve de vínculo entre as coisas. Merleau-Ponty chama a atenção à universalidade, à não cristalização. Afirma que existe um emaranhado possível das relações, que surge de uma multiplicidade de confrontos, intercâmbios e transformações: 
Nenhuma relação pode ser arbitrariamente isolada de todas as outras nem é possível permanecer aquém ou além do nosso mundo das relações: o ambiente social não deve ser concebido como uma moldura vazia no interior da qual os seres e as coisas podem ser ligados, ou simplesmente justapostos. O ambiente é inseparável das coisas que o povoam, o conjunto destas constitui um campo de gravitação no qual as cargas e as distâncias formam um conjunto coordenado em que cada elemento, modificando-se, provoca uma mudança no equilibro do sistema (BONOMI, 1974)

Estão nessas relações que consideram o subjetivo e o objetivo, o visível e o invisível, sem limites indissociáveis, a buscar da transcendência, que Merleau-Ponty chamou de "redução fenomenológica", que para Husserl não é "nem construção nem anulação, (mas) uma modificação do olhar, dirigida para a investigação da própria experiência natural" (HUSSERL apud BONOMI, 1974). A redução para MerleauPonty traz à luz uma zona do ser onde "subjetividade e objetividade se envolvem uma na outra, e onde, no limite são indissociáveis" (MERLEAU-PONTY apud BONOMI, 1974) o que levaria à transcendência. Considera-se aqui que a transcendência se encontra no espaço entre o visível e o invisível, sendo que "o invisível não é o contrário do visível, não se pode vê-lo e todo esforço para vê-lo, o faria desaparecer. O invisível está em volta do visível, na linha do visível e ele reside aí sem ser objeto, (como) pura transcendência” (MERLEAU-PONTY apud DIAS, 2010). Relações perceptivas predispõem posicionamento. Dias (2010) comenta que "estamos em meio às coisas do mundo e segundo a nossa disposição sensível e mental a experimentamos ou não". Segundo a autora, não vemos o mundo "segundo o seu envoltório exterior" vivemo-lo por dentro, "pensando bem, o mundo está ao redor de mim, não diante de mim" (DIAS, 2010). Para Martins (1992), com a redução fenomenológica deseja-se encontrar exatamente, que partes da experiência são verdadeiramente partes da nossa consciência, diferenciando-se daquelas que (são) simplesmente supostas (MARTINS, 1992 apud OLIVEIRA, 2008).

O que se propõe com a escolha da fenomenologia para uma investigação é "não desagregar a evidência do mundo, nem construir uma nova como se ela nunca tivesse existido (...), é modificar a direção do olhar, que não será mais dirigido (como na atitude natural) para o mundo e as coisas da experiência, mas para aquela dimensão em que se constituem essas coisas e esse mundo (BONOMI, 1974). Para Husserl (Husserl apud BONOMI, 1974), na experiência cotidiana, o sujeito está "naturalmente" voltado 
para os objetos, à medida que os percebe, manipula-os e deseja-os e é levado a dissimular os atos intencionais que os constituíram e em uma atitude natural: o sujeito é sujeito do seu mundo circundante, em uma relação intersubjetiva, não é como objeto entre objetos que apreende o outro, mas como pessoa como centro de um comportamento ativo. Sendo assim uma atitude subjetiva transcendental implica uma reviravolta total do olhar natural, reduz todo ente a mero fenômeno para uma consciência transcendental. Não mais os objetos dados, mas como eles vêm a ser constituídos. A aplicação da redução fenomenológica adentra o campo de experiências perceptivas, práticas e se oferece em sua originalidade onde o eu vive "espontaneamente como sujeito que desde sempre tem esse mundo que não põe em duvida seu ser aqui e agora" (BONOMI, 1974). Pede um olhar reflexivo, que na fala do autor se dá na inversão do olhar:

\footnotetext{
Pela inversão do olhar, operada na reflexão, não estou mais interessado no ser das representações e sim, nas formações originárias de sentido, onde se constitui o objeto-mundo (...) Do ponto de vista epistemológico, o método fenomenológico é contrário às idéias que isolam o sujeito ou o objeto para o desenvolvimento de estudos, concebendo-os como correlacionados. Há, portanto, o entendimento que numa relação entre sujeito e objeto, um não pode existir sem o outro. (BONOMI, 1974)
}

Para Masini (1989), o método fenomenológico é centrado no ser humano, especificamente na análise do significado e relevância da experiência humana. $\mathrm{O}$ ponto de partida da investigação fenomenológica é a compreensão do viver do próprio homem. O homem imprime sentidos ao mundo, ao ser capaz de intuir, tendo intencionalidades, orientando significações sobre tudo aquilo que vai experenciando em sua existência. Ao estabelecer significações para os objetos que analisa e interpreta, o homem une-se a eles. A pesquisa fenomenológica, para Masini (1989), parte da compreensão de nosso viver - não de definições ou conceitos - da compreensão que orienta a atenção daquilo que se vai investigar. Ao percebermos novas características do fenômeno, ou ao encontrarmos no outro, interpretações, ou compreensões diferentes, surge para nós uma nova interpretação que levará a outra, assim o método fenomenológico apresenta consistência e legitimidade em estudos científicos que enfatizam a experiência vivida do homem e sua significação, principalmente, quando não é possível explicá-la por uma relação de causa e efeito, reduzindo-a, a normas, 
princípios, definições ou conceitos previamente estabelecidos (MASINI,1989 apud OLIVEIRA, 2008).

Nessa perspectiva, o pesquisador não parte de um referencial teórico previamente estabelecido. É por meio das experiências que é possível ao investigador interrogar o mundo que o circunda em busca do entendimento do fenômeno (OLIVEIRA, 2008). Para Martins (1992),

o que se objetiva na pesquisa fenomenológica são os significados que os sujeitos atribuem à sua experiência vivida, significados esses que se revelam a partir das descrições realizadas por esses mesmos sujeitos. A descrição da experiência por quem vivencia um fenômeno é o caminho para a compreensão dele, e a linguagem é uma das formas que se abre para essa compreensão (MARTINS,1992 apud OLIVEIRA,2008).

Segundo Triviños (2002)

essa forma de se pensar e conduzir a pesquisa apresenta em si à questão da subjetividade. Contudo, tanto o sujeito como o fenômeno estudado está no mundo-vida com outros sujeitos, que também percebem e vivenciam os fenômenos. Sujeitos que participam de experiências vividas em comum, compartilham entendimentos, interpretações, comunicações, estabelecendo-se assim, a esfera da intersubjetividade (TRIVIÑOS,2002 apud OLIVEIRA,2008).

Para Husserl existem duas ciências que avançam no conhecimento: a ciência natural e o conhecimento filosófico. A ciência natural não se preocupa com a crítica do conhecimento, mas como as coisas são dadas no intelecto. O que se capta: a coisa. No mundo natural, estão os juízos humanos, e por suas percepções é que se estabelecem as definições: "exprimimos o que a experiência direta nos oferece". E é nesse conhecimento natural que os problemas são resolvidos de maneira lógica. A ciência natural não questiona o conhecimento. E aí precisa-se do conhecimento filosófico (BONOMI, 1974).

Uma análise fenomenológica como método que articule as experiências e percepções dos sujeitos no Turismo foi desenvolvida por Alexandre Panosso Netto em seu livro Filosofia do Turismo: Teoria e Epistemologia, que propõe reflexões filosóficas que vai ao encontro de Hurssel quanto à necessidade de se reaprender a ver o mundo. Netto (2011) posiciona o homem como aquele que dá significado ao Turismo, 
faz uma análise do turismo que reconduz e enfoca o ser humano como sujeito do fenômeno turístico. Critica a visão positivista do Turismo e sua abordagem reducionista e o define como um fenômeno complexo e multidirecional, propondo uma leitura sem pré-conceitos na análise do Turismo, que dialoga com a posição de Merleau-Ponty quanto à observação objetivista do objeto fechado em si mesmo. Afirma o turismo como experiência e como fenômeno e considera sua essência e sua apreensão pela consciência: "Fenômeno é a percepção do objeto que se torna visível à nossa consciência" (MOREIRA apud NETTO, 2011), dialoga com a ideia de que um objeto no mundo ao nosso redor percebemos pelos sentidos, por um estímulo sensorial, que ao ser transformado em uma experiência organizada caracteriza a percepção e assim como, para Merlau-Ponty o conceito de percepção é um emaranhado de significações, o turismo é entendido por Netto como um emaranhado de relações, onde há de se considerar o sujeito, o tempo e o espaço, entendendo então o turismo como algo maior do que as relações de consumo e mercado, não apenas na perspectiva da sociedade de consumo, mas como um "estudo das razões essenciais e do significado transcendente do turismo para os seres humanos em função do seu próprio mundo interior" (BARRETO apud NETTO).

Netto (2011) qualifica o Turismo como um processo que abarca as "necessidades, anseios e desejos humanos" e considera a abordagem fenomenológica como aquela que possibilita "novas possibilidades para o estudo no campo do turismo, pois ela quer ser ciência e método, a fim de elucidar possibilidades do conhecimento e valoração a partir da essência.", não qualifica a fenomenologia como o melhor ou único método, mas como proposta, dentre outras, de análise aplicada ao turismo.

Sendo assim, o presente projeto se apresenta pela necessidade de uma renovação dos conceitos sobre o Turismo, considerando seus interespaços - que se localizam entre as causas e os efeitos -, não como espaços vazios, mas como algo que pulsa, que é orgânico, significante e que existe em um trânsito dialético latejante, metamorficamente configurado, remodelado e alimentado pelo exercício da percepção. E pela percepção predispõem-se as novas leituras para o Turismo, este fenômeno pertencente a uma realidade dinâmica, que reflete e trabalha com as essências da vida do ser humano. 
Nesse sentido, a fenomenologia é a metodologia que mais se aproxima desta investigação e foi, portanto, escolhida como caminho para a elaboração deste trabalho, na busca pelo Turismo como um espaço de multiplicidades, para que seu entendimento seja mais alma que matéria, sua prática mais voltada ao humano que ao mercadológico e que descobertas e desdobramentos do sensível promovam inter-relações mais focadas no capital social ${ }^{13}$, por novas interpretações possíveis em busca de um conceito vivo que dialogue com seu tempo e sociedade, repletos de existências significativas.

${ }^{13}$ Capital social na definição de Pierre Bourdieu é um "conjunto dos recursos reais ou potenciais que estão ligados à posse de uma rede durável de relações mais ou menos institucionalizadas de interconhecimento e de inter-reconhecimento mútuos, ou, em outros termos, à vinculação a um grupo, como o conjunto de agentes que não somente são dotados de propriedades comuns (passíveis de serem percebidas pelo observador, pelos outros e por eles mesmos), mas também que são unidos por ligações permanentes e úteis". BOURDIEU, P. O capital social - notas provisórias. In: CATANI, A. \& NOGUEIRA, M. A. (Orgs.) Escritos de Educação. Petrópolis: Vozes, 1998. 


\section{O TURISMO E O TURISTA CIDADÃO}

Figura 03: Pessoas caminhando e igreja ao fundo de Tarsila do Amaral (1924)

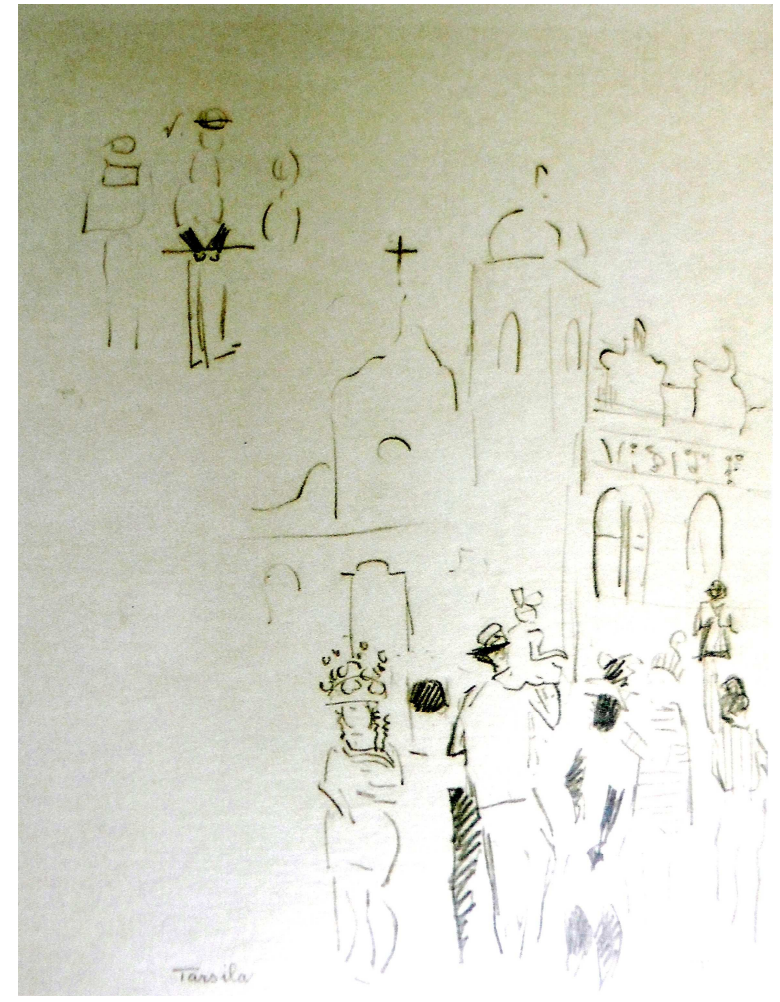

Fonte: Tarsila Viajante (2008)

O histórico conceitual do que vem a ser o Turismo remonta aos primórdios do século XIX e vai se transformando com o passar dos anos de acordo com as necessidades de definições que o identifiquem com suas características essenciais. Sendo assim, uma variedade de significações vai se formando a partir do séc. XIX momento em que o Turismo começa a se desenvolver como prática social demonstrando as inúmeras interpretações que, em sua maioria, abordam o Turismo como uma prática relativa datada e determinada, sendo causa e efeito de um processo.

Historicamente ele se desenvolve com o capitalismo e ainda hoje os conceitos sobre o Turismo permeiam o campo utilitarista capitalista. É comumente entendido como atividade fonte de lucro e investimentos, caracterizada pela economia produzida 
pelo tráfego de indivíduos, grupos ou massa que se deslocam exercendo atividade de lazer, saindo do seu local de residência para um lugar de não domicilio em uma permanência temporária com retorno intencional. São muitos os conceitos e teorias deterministas sobre o que possa vir a ser o Turismo e os signos utilizados: turista, férias, tempo livre, recreio, trabalho, residência, deslocamento, viagem, estrada, caminho, fronteiras, etc. Estes signos assumem ordens mecânicas e formas objetivas, desconsiderando contextos interpretativos diversos para abarcar diferentes visões. Fato que colabora para o reducionismo do entendimento sobre o Turismo.

Para superar a possibilidade de ver o Turismo de forma fechada, datada e determinada, propõe-se então uma abordagem que amplie as significações dos signos do Turismo e que contemple novos olhares sobre este fenômeno, a partir de uma visão sistêmica orgânica, complexa, crítica e dialética, para uma possível interpretação do homem, da sociedade, do mundo e seus acontecimentos pelas suas práticas (MOESCH, 2004), pois o Turismo por mais que envolva programas, poderes, financiamentos, só existe porque é feito por pessoas e por elas se consagra sua existência. Uma busca da construção do capital social para além do determinismo econômico, para se enxergar além da sua aparência, sua essência, em uma visão humanista. O presente projeto visa considerar os modos de ver, reagir, sentir de cada um, as percepções dos indivíduos em contraponto à tendência pela definição econômica. Às vezes, o turista é a própria definição de turismo e poucas são as aberturas para uma definição que envolva experiência, aprendizado, percepção e transformação de quem realiza sua prática.

Para tanto há que se considerar conceitos subjetivos como as percepções, as interpretações, as atitudes, as escolhas, as trocas culturais, em uma proposta de perceber as inúmeras facetas em que está inserido esse fenômeno, muito mais complexo e mais suscetível às mudanças e avanços da sociedade e, portanto muito difícil de ser fechado em uma determinada teoria. Há a necessidade de um olhar menos restrito para uma melhor compreensão do seu significado, pois se "são os homens que se deslocam e não as mercadorias" (MOESCH, 2004), precisa-se considerar então o ser humano nessa viagem exploratória e para tanto, vale considerar o turismo como um fenômeno de interrelações socioculturais, onde a vivência do turista e seus ganhos imateriais constituem dados de rentabilidade no campo da essência e do subjetivo. 
Sendo assim, investigar o Turismo é explorar os múltiplos aspectos que o envolvem e perceber o entrelace das adjacências conceituais que transitam entre as compreensões sobre tempo e espaço, bens e consumo, essência e matéria, bem como o próprio sujeito e os espaços visitados. É ver o Turismo além da aparência, é buscar superar as concepções deterministas que o tem como causa e efeito de um sistema econômico. É entendê-lo pelo aspecto transdisciplinar e analisá-lo fenomenologicamente como um processo e não como um fim, indo ao encontro de conceitos contemporâneos que foca nas relações humanas do sujeito e suas características, que o qualificam como um fenômeno, buscando a contribuição na evolução da sua episteme, evolução enquanto transposição, transformação, para a desconstrução da visão simplista, fechada e determinada dos modelos que o relacionam unicamente às produções, distribuições e consumo de bens e serviços.

Junto ao posicionamento humanista do Turismo, este projeto de dissertação traz o conceito do turista cidadão para melhor embasar o problema de pesquisa. $\mathrm{O}$ conceito de turista entendido como "todos aqueles que se deslocam fora do seu domicílio habitual” (FUSTER,2001 apud MOESCH, 2004), cai por terra quando se é apresentado o conceito de turista cidadão, desenvolvido por Gastal e Moesch (2006), como aquele usuário da cidade, que se apropria dela enquanto se desloca e que considera também a proposta de turismo sob o olhar do residente.

Turista cidadão é o habitante que desenvolve um relacionamento diferenciado com o local onde mora no seu tempo de lazer, quebrando o modelo existencial da sociedade industrial criticado por Jost Krippendorf (trabalho - moradia - lazer - viagem), de acordo com o qual o lazer, as práticas sociais capazes de restabelecer o equilíbrio físico e emocional do homem contemporâneo, só seria possível em lugares distantes da própria residência. (SALLES apud GASTAL, 2006) 
Figura 04: Turista cidadão em potencial em uma Superquadra de Brasília

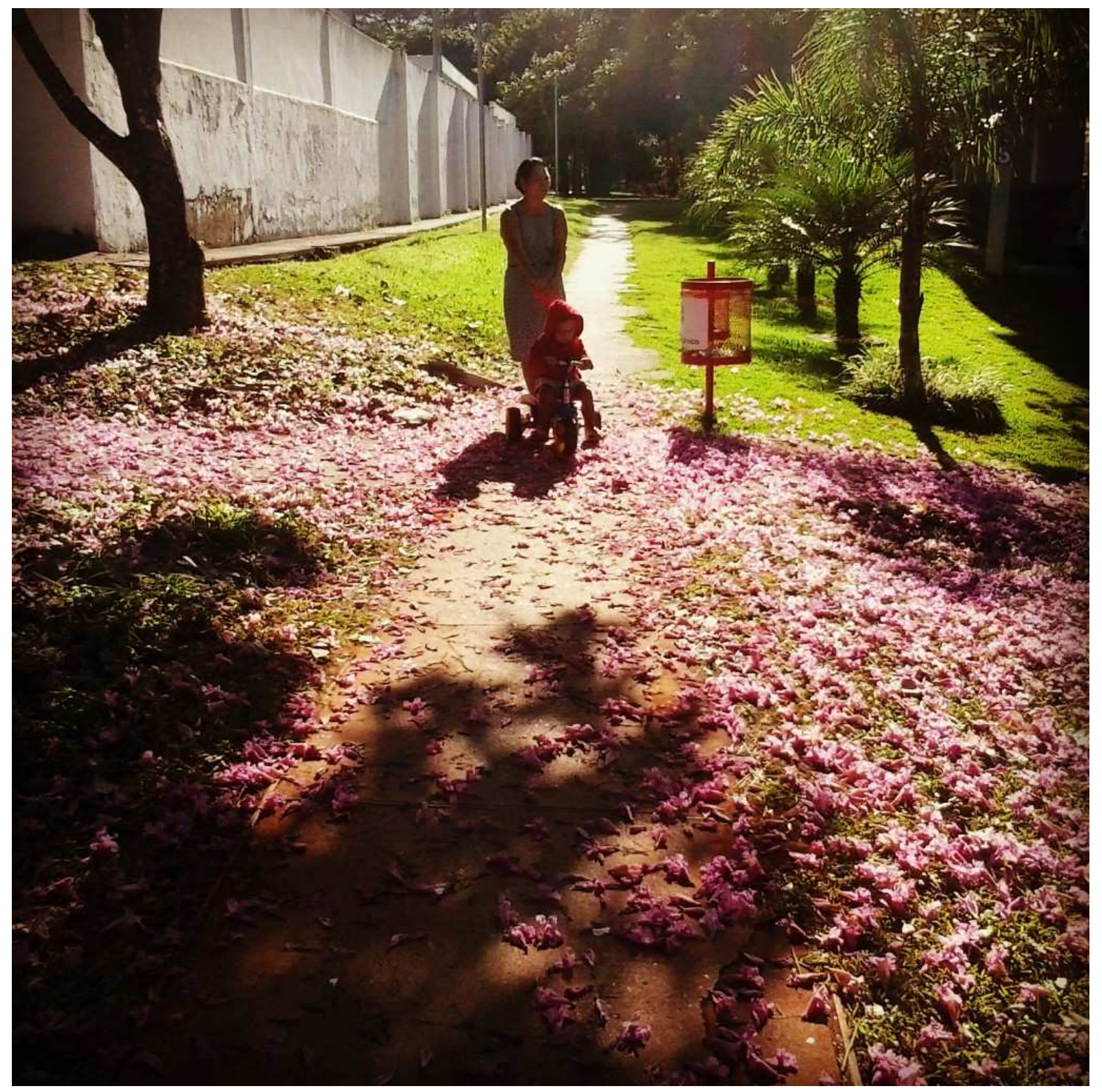

Fonte: Tatiana Terra (2013)

Segundo Gastal e Moesch (2006), o turista cidadão é o próprio morador da localidade que mesmo em seu tempo rotineiro, consegue sair da rotina fazendo o uso do estranhamento da cidade. Nesse momento, o indivíduo no espaço cotidiano, descobre novas oportunidades de lazer e entretenimento, outras culturas e outras formas "Quando se encontra na situação de turista cidadão este sujeito aprende a utilizar os espaços ambientais, culturais, históricos, comerciais e de entretenimento com uma percepção diferenciada do seu cotidiano" (MOESCH, 2005 apud GASTAL, 2006), avançando na "complexidade como ser humano, pertencente ao social e mais consciente do seu 
posicionamento no mundo (que) soma 'identidade e identificação' em um espaço qualificado para auto-expressão" (GASTAL, 2006).

Figuras 05 e 06: Apropriação dos espaços das Superquadras para uma festa popular (Festa Junina -2014)
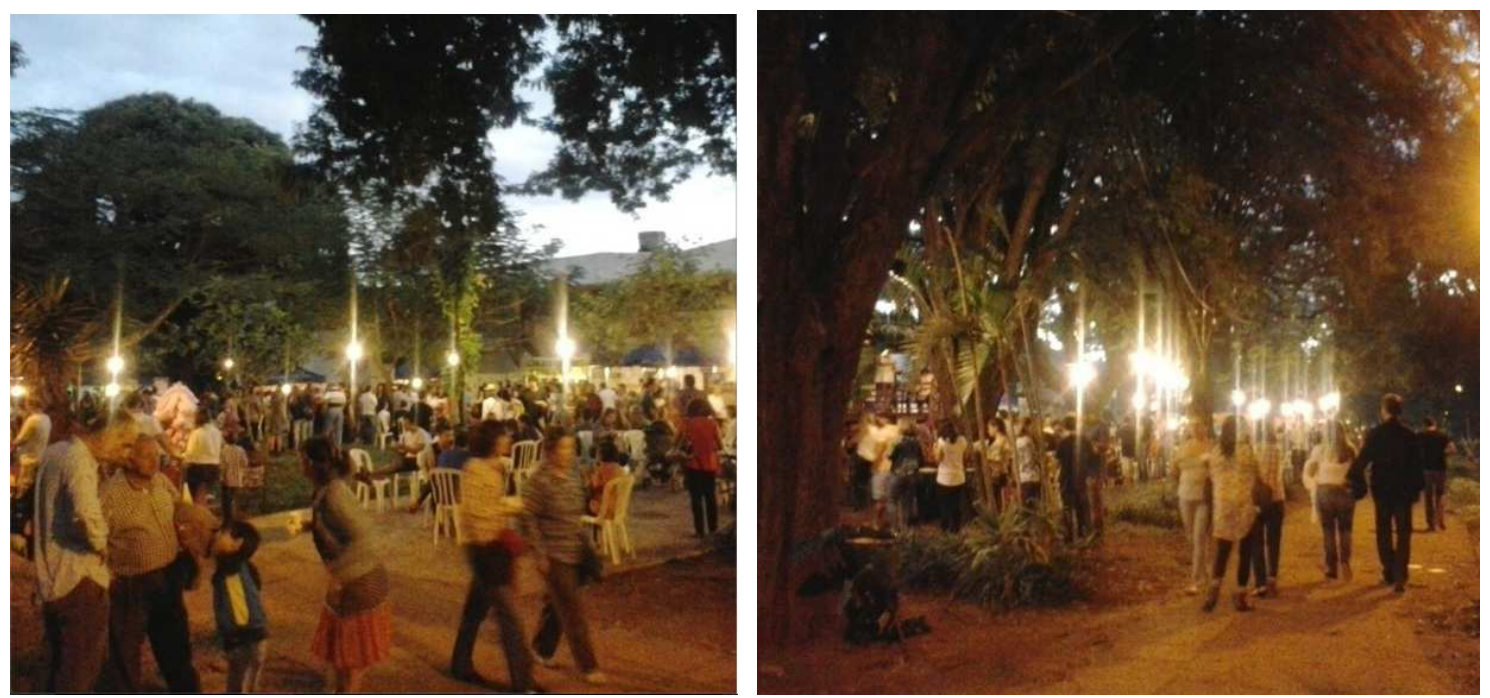

Fonte: Tatiana Terra (2012)

Esta definição é um avanço no conceito de se fazer turismo na contemporaneidade, pois "a apreensão de uma cidade é sempre incerta, incompleta e exploratória e nunca acabamos de explorar uma cidade, mesmo quando há muito a habitamos" (LADRIÈRE, 1979). E é a partir desse entendimento que essa pesquisa sugere a utilização do conceito de turista cidadão na cidade de Brasília, o que viabiliza a interpretação do espaço pelo sensível, considerando as percepções do próprio habitante da cidade enquanto este experimenta a paisagem ao caminhar. 


\section{II - ESPAÇO TRAÇADO}

\section{O DESENHO URBANO}

A cidade como campo de investigação atravessa as mais diversas leituras em diferentes campos do conhecimento. Conceitos são formados por linhas de pensamento que necessariamente não se opõe, mas que se completam devido à complexidade de se estabelecer um conceito único sobre um objeto de inúmeras particularidades. Estudar as cidades considera seu surgimento, sua criação e o seu desenvolvimento.

A cidade é percebida como um "local de estabelecimento aparelhado, diferenciado e ao mesmo tempo privilegiado, sede da autoridade" (BENEVOLO, 2012), como um objeto complexo que responde, entre outras, às funções, que vão do lugar de habitar, ao de trabalho, de encontro, de interação desses encontros, de tempo livre (LADRIÈRE, 1979).

Para o historiador americano Mumford (1945) a cidade é reconhecida como o lugar onde os benefícios da civilização são múltiplos e variados, onde a experiência humana se transforma em signos visíveis, símbolos, normas de conduta e sistemas de ordem; onde também se concentram os destinos da civilização e que em certas ocasiões, o ritual se transforma em drama ativo de uma sociedade totalmente diferenciada e consciente de si mesma. Para ele a cidade está suscetível a intervenções de elementos externos que ao se fundirem no espaço da cidade, se transformam não só no espaço como no pensamento humano:

\footnotetext{
Um navio mercante ou uma caravana que se detém na cidade podem trazer uma nova cor para a lã, um brilho novo para o torno do oleiro, um novo sistema de signos para as comunicações a longa distância ou um pensamento novo sobre o destino humano (MUMFORD, 1945). (tradução livre da autora)
}

Mumford (1945) entende que a cidade se configura em um "plexo geográfico, uma organização econômica, um processo institucional, um teatro de ação social e um símbolo estético de unidade coletiva", sendo para ele palco e ao mesmo tempo a própria 
manifestação da arte representada, onde há a confluência da vida humana por suas ações em busca de uma obra coletiva:

Cria o teatro e é o teatro (...) sem o drama social da existência que vem da concentração e intensificação da atividade social do grupo, não há um só feito que possa ser executado (...) é uma armação especial que favorece a criação de oportunidades diferenciadas para alcançar uma vida comum e um drama coletivo significativo (MUMFORD, 1945). (tradução livre da autora)

Para o geógrafo Milton Santos (2014), as cidades são como próteses, acréscimo à própria natureza. Um "prolongamento da terra" (SANTOS,2014), como são os instrumentos de trabalho compreendidos como prolongamentos do homem, para ele a cidade é um lugar de "ebulição permanente" (SANTOS,2014). Evidenciar a cidade como "acréscimo ao natural" (SANTOS,2014), aproxima-se do pensamento de Mumford, que considera cada uma das fases da vida do campo uma contribuição para a existência das cidades, estas um produto da terra quando refletem "a astúcia do paisano em dominá-la” (MUMFORD,1945) em uma complexa orquestração de tempo e espaço, onde o tempo se faz visível pelos edifícios, monumentos e avenidas públicas.

Uma vertente para o entendimento de uma cidade é ir à origem da sua criação. Em sua maioria, as cidades são formadas pelas necessidades sociais do homem, seja pelo desenvolvimento e crescimento de um comércio, pelas alternâncias das práticas econômicas na localidade, pela necessidade de proteção de um país. O histórico do surgimento das cidades nos mostra que já foram elas semente de liberdade da época feudal, nasceram do trabalho livre, geraram produções históricas e sociais, se formaram pelo avanço das técnicas de produção agrícola e pelo excedente de produtos alimentares, renasceram pelo movimento de trocas comerciais, promoveram intercâmbio de profissões, impulsionaram o desenvolvimento e aperfeiçoamento de técnicas, e ainda constituíram-se como local de criação e transmissão de conhecimento privilegiado (SANTOS, 2014). Aldeias que se desenvolviam se tornavam cidades quando as indústrias e os serviços deixaram de ser executados pela comunidade agrícola e passaram a ser mantidas pelos agricultores como excedente do produto local. O que era produzido no campo e distribuído na cidade influenciou na composição e atividades das classes dominantes repercutindo em toda sociedade. E em seu desenvolvimento as cidades, que um dia também passaram a ser locais de refúgio, em muitos casos, 
cresceram e crescem sobre o traçado da antiga, em outras as modificações das construções arquitetônicas de moradia sofreram as adaptações necessárias à população, deixando de lado - no geral - o estudo das estradas e edifícios e bairros por inteiro, focando o estudo em monumentos (BENEVOLO, 2012).

Segundo Bevenolo (2012) a origem das regras para planificação das cidades é atribuída aos etruscos - povos que dominavam a região da Etrúria antes da chegada do império romano, bem como a inauguração de uma cidade, regra posteriormente adotada pelos romanos e difundida mundialmente. A demarcação do perímetro urbano e limites (Limitatio) era regra de origem romana. Os romanos consultavam a vontade dos deuses antes de se inaugurar uma cidade (Inauguratio) e posteriormente realizavam um sacrifício na cidade recém fundada (Consacratio) (BENEVOLO, 2012).

Contudo aliadas às regras de planificação, toda necessidade humana catalisadora dos surgimentos das cidades esbarra na natureza dos lugares. Assim podemos considerar que junto às necessidades humanas, o espaço condiciona a formação de organizações sociais estruturadas e organizadas. As mais antigas regras de ordenação social comunitária aparecem já nas sociedades neolíticas bem como naquelas onde o desenvolvimento das comunidades se fixavam ao longo dos rios, em planícies cultiváveis onde passam ou se podiam conduzir água de um rio ou nascente, para favorecimento do comércio e das comunicações: "marés e terrenos abertos às comunicações favorecem as trocas de mercadorias e de notícia" sob o céu que permitia a visão dos movimentos dos astros e facilitam a medição do tempo (BENEVOLO, 2012). Mas a cidade, confluência da vida humana, conforme mencionado anteriormente, também é palco de trocas humanas, ela é, nas palavras de Lucio Costa, a "expressão palpável da humana necessidade de contato, comunicação, organização e troca - numa determinada circunstância físico-social e num contexto histórico" (COSTA, 2001). E em um entendimento comum - ao contrário de Zoé ${ }^{14}$ - nela tudo tem seu lugar, configura-se e é configurada dialeticamente entre sua forma natural e necessidades humanas, entre eventos e devaneios. É traço e traçado de um desenho nunca finalizado,

14 Zoé é uma das cidades invisíveis de Calvino. É o lugar onde a existência é indivisível, onde tudo pode ser feito em todos os pontos da cidade, onde as edificações não sinalizam sua função e, portanto dificulta a associação de referências do visitante, que confuso, questiona sua finalidade in Cidades Invisíveis, de Ítalo Calvino, 1990. 
forma mapas efêmeros, e ainda que apresente elementos aparentemente fixos em estruturas imóveis, se renova em aspectos funcionais. Numa cidade nada é perene e ainda assim, inquestionável é, o motivo de sua existência.

Figura 07: Estrada de Ferro Central do Brasil (1924) - Tarsila do Amaral

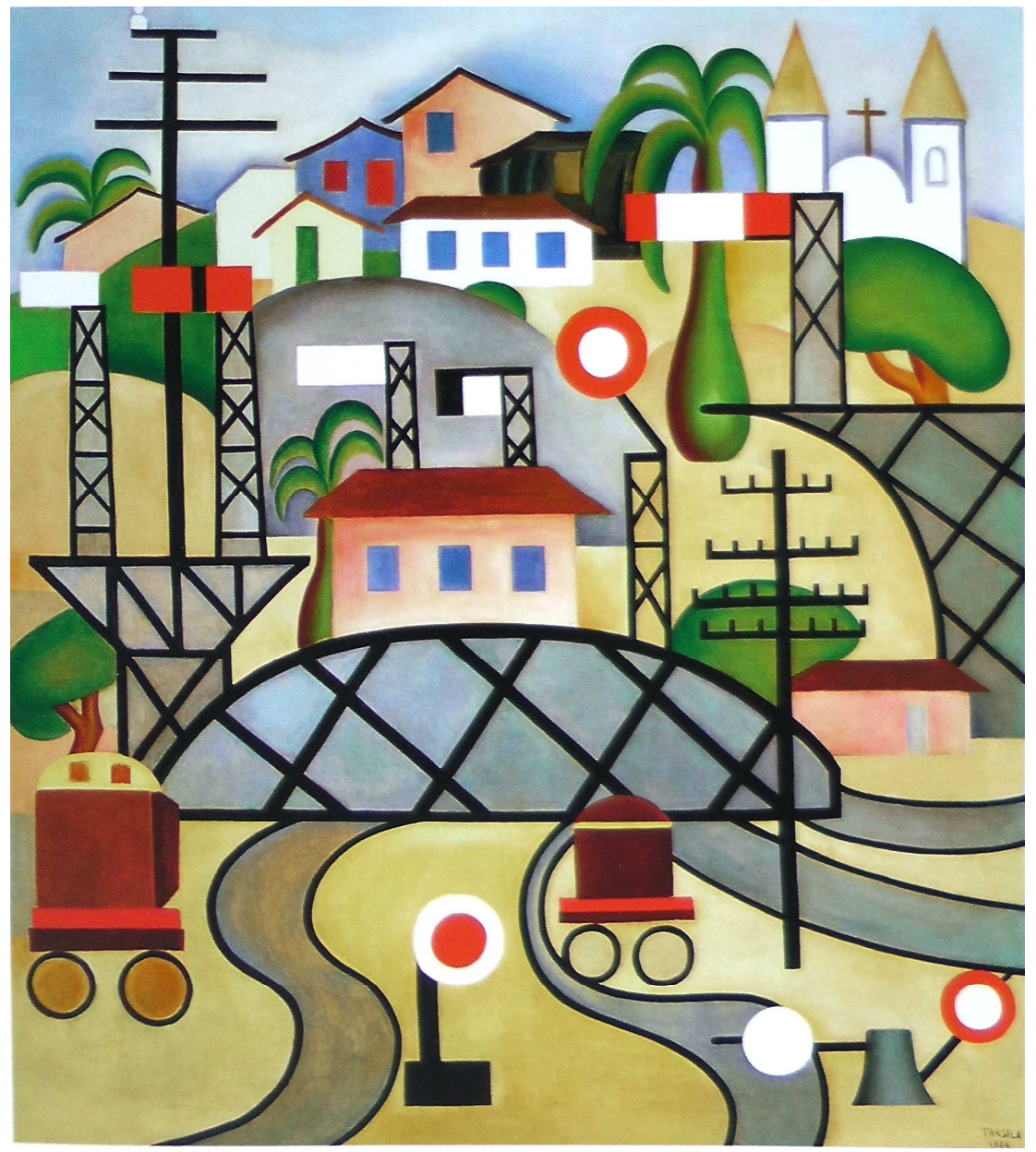

Fonte: Tarsila Viajante (2008)

Quando se investiga o desenho urbano das cidades brasileiras e se vai à criação das primeiras urbes, é muito comum a comparação estabelecida entre as cidades colonizadas pelos espanhóis nas Américas e o Brasil colonizado por Portugal. É quase que unânime as interpretações sobre a falta de planejamento urbano do lado português diante a organização espanhola para suas cidades da América Central e Meridional. Benevolo (2012) em seu livro "História da Cidade" (2012), sugere tal desinteresse pelo foco do uso das terras para o comércio em contrapartida à colonização, diz que "os portugueses, em seu hemisfério, encontraram territórios pobres e inóspitos (...) e assim 
construíram uma série de bases navais, para controlar o comércio oceânico”. O autor ratifica que os portugueses em terras brasileiras não tinham condições de realizar uma verdadeira colonização em grande escala, enquanto espanhóis encontraram territórios mais adequados à colonização: planaltos com impérios mais ricos, desenvolvidos e incapazes de resistir aos conquistadores europeus. No entanto o fato de que não houvera planejamento para as cidades do Brasil-Colônia, levou a pesquisadora americana Roberta Marx Delson investigar a fundo essa questão cujo resultado foi a publicação de um importante livro denominado "New Towns for Colonial Brazil" (1979), traduzido no mesmo ano no Brasil como "Novas Vilas para o Brasil Colonial". Ela questiona as afirmações dos historiadores e sociólogos de que "os portugueses, na era colonial, ao contrário dos seus contemporâneos espanhóis, não tinham nenhum desejo preconcebido de estabelecer um ordenamento urbano", questiona se foram os portugueses "relaxados e irresponsáveis com relação ao desenvolvimento municipal brasileiro" e se seria até a criação de Brasília, o Brasil um país desprovido de planificação urbana formal. Em sua pesquisa, Delson (1979) acaba por concluir que a falta de planejamento para as cidades do Brasil colonial, na realidade é um mito:

\footnotetext{
Desde os primeiros anos do povoamento português, quando o governador-geral Tomé de Souza chegou para construir a capital de Salvador da Bahia como uma planta já traçada no bolso, há indícios da preocupação da Coroa Portuguesa com o desenvolvimento de centros urbanos primários (...) que no século XVIII foi sistematizada numa filosofia completa de planejamento urbano (DELSON, 1979). (grifo da autora)
}

Isso porque as características do desenho urbano no Brasil se configuravam como a própria representação do poder português sobre o território:

\begin{abstract}
O Planejamento urbano no Brasil chegou à política de controle e absolutismo: a configuração urbana caprichosamente regulamentada que orientou a construção interiorana no século XVIII desenvolveu-se como uma representação simbólica de "bom governo", uma indicação de que a sociedade estava funcionando dentro de limites predeterminados e disciplinados (DELSON, 1979).
\end{abstract}

A autora estuda o desenvolvimento de várias vilas e assevera que, ao contrário do que afirmam historiadores sobre a formação das cidades na América Latina, as cidades no Brasil não foram surgindo por povoações espontâneas, sem planificação, sem normas de planejamento. Posiciona-se contrária aos especialistas que marcam o fim do crescimento aleatório das cidades do Brasil na década de 1950 com a construção de 
Brasília, que se tornaria então o retrato de uma nova era de consciência urbana brasileira.

O que ocorria na época da colonização das Américas era a implementação do planejamento xadrez nas terras conquistadas, um padrão de planificação em forma quadriculada que consistia em um modelo uniforme para cidades idealizado pelos espanhóis no século XVI. O desenho deste plano

remete a um tabuleiro de ruas retilíneas, que define uma série de quarteirões iguais, quase sempre quadrados, onde suprimindo ou reduzindo algum desses quarteirões, consegue-se uma praça, onde se posicionam os monumentos principais da cidade. A cidade também pode crescer estendendo o desenho do tabuleiro em todos os sentidos. (BENEVOLO,2012).

Este modelo, que a princípio, teria sido importado pelos portugueses para amoldamento em terras tropicais, não favorecia a "adaptação ao caráter dos lugares" (DELSON,1979) e a fama da desordem portuguesa começava a ser instaurada. Sérgio Buarque de Holanda, em Raízes do Brasil (1995), explica a renúncia às regras formais em nossas terras que, contrária a fama de desmazelo, comenta que seria senão um movimento cuidadoso dos portugueses diante das terras conquistadas, atenta que "a rotina e não a razão abstrata foi o princípio que norteou os portugueses (...) em suas atividades colonizadoras" (HOLANDA,1995). Considera ainda o acréscimo da personalidade portuguesa que imprime desde já, características ao espaço e quem sabe senão, na formação da sociedade que viria a surgir na cidade, pois como já dizia Mumford (1945) "a mente adquire forma na cidade assim como as formas urbanas condicionam a mente humana"15

Pontua Holanda (1995):

Pode-se acrescentar que tal convicção, longe de exprimir desapego ou desprezo por esta vida, se prende antes a um realismo fundamental, que renuncia a transfigurar a realidade por meio de imaginações delirantes ou códigos de postura e regras formais (salvo nos casos onde estas regras já tenham estereotipado em convenções e dispensem assim, qualquer esforço ou artifício). Que aceita a vida, em suma, como a vida é, sem cerimônias, sem ilusões, sem impaciências, sem malícia e, muitas vezes, sem alegria (....) a expansão dos portugueses

\footnotetext{
${ }^{15}$ tradução livre da autora
} 
no mundo representou sobretudo obra de prudência, de juízo discreto, de entendimento 'que experiências fazem repousado'.

Se não eram os planos "trazidos nos bolsos" executados pelos portugueses em terras brasileiras, muito se deve às características da topografia da região das terras brasileiras. "O esquema retangular (...) encontrava no Brasil empecilhos naturais, seria ilusório, contudo, supor que sua presença resultasse da atração das formas fixas e preestabelecidas" (HOLANDA,1995). Sendo assim, os portugueses, ao se depararem com as características da topografia das terras que aqui encontraram, entenderam que mais coerente que impor um desenho europeu em superfície brasileira, era respeitar o natural "enlace na linha da paisagem", uma forma de deixar a cidade se desenhar quando esta ao mesmo tempo imprime características da sociedade que nela se forma. Diz Holanda (1995)

Seja como for, o traçado geométrico jamais pode alcançar, entre nós, a importância que veio a ter em terras da Coroa de Castela: não raro desenvolvimento ulterior dos centros urbanos repeliu aqui esse esquema inicial para obedecer antes às sugestões topográficas.

Assim os portugueses optaram por observar as características não só naturais da região, bem como as organizações sociais aqui já estabelecidas para desenvolver as cidades que desejavam, e as cidades foram se formando e se desenvolvendo apresentando diferentes formas urbanas que estão relacionadas aos momentos históricos, sociais, econômicos e/ou políticos. Como a ocupação portuguesa no Brasil era basicamente litorânea, as poucas vezes que adentrava o território brasileiro era pela necessidade de expansão da produção da cana-de-açúcar. As cidades do Brasil colônia localizadas no litoral foram determinadas pela necessidade de defesa do território e pelo fluxo de comércio e, curiosamente, estas cidades como todas as outras cidades brasileiras, foram inventadas, sendo assim, inventar cidades passa a ser então uma tradição do país (BARBIERI, 2010). Inventar cidades como tradição é uma afirmação relatada por especialistas no documentário "Cidades Inventadas” de Renato Barbieri (2010) e chama a atenção para este fator histórico, o das construções das cidades no Brasil que começa com os portugueses, mas torna-se um fato que se manteve durante os séculos. O documentário apresenta o fato de que os portugueses diferentemente dos espanhóis quando chegaram ao México ou ao Peru, não encontraram nessas regiões, que hoje pertencem ao Brasil, nenhuma cidade construída, nem sociedades organizadas em 
estados centralizados com milhares de habitantes e ainda que eles tenham encontrado povos indígenas que falavam cerca de mil línguas diferentes, nenhuma estrutura urbana, enquanto estrutura de cidade definida havia no Brasil. No entanto, havia as aldeias indígenas e de acordo com Caldeira (2007) seus desenhos apresentavam edificações que variavam entre formas únicas como as casa-tribo ou casa-aldeia, de formato elíptico ou retangular e aldeias mais complexas que alternavam o número de edificações e formatos, configuradas de acordo com os costumes das tribos, funções ritualísticas e definições espaciais de hierarquia em uma ordenação espacial e social. Demonstravam uma organização desenvolvida e certos padrões espaciais. Assim, não só a forma de organização das aldeias brasileiras como também a maneira de se resolver a arquitetura pelas técnicas usadas de acordo com os recursos disponíveis na época, influenciaram os portugueses em suas primeiras experiências de ocupação territorial e esboçaram um posterior desenvolvimento das primeiras vilas no Brasil (CALDEIRA, 2007).

\section{O DESENHO URBANO: SALVADOR}

Faz parte da história brasileira a transformação de vilas em cidades com projetos de alto nível urbanístico, como é o caso de Salvador e Recife, assim como também pertence a nossa história, a criação de cidades inventadas, como é o caso de Brasília, construída em um território "anteriormente habitado, porém desprovida de qualquer concepção urbana" (OLIVEIRA in BARBIEIRI, 2010). Salvador e Recife são cidades brasileiras que apresentam diferentes planificações urbanas. Reconhecemos o desenho da cidade de Salvador pelo seu histórico e configuração espacial relacionada à sua topografia e defesa do território e, a cidade de Recife pela influência artística de Maurício de Nassau. Dois vértices distintos, de construção de cidades brasileiras.

A criação da cidade de Salvador teve como objetivos econômicos, geopolíticos e estratégicos de ocupação do novo continente e também a necessidade de Portugal em administrar sua colônia e ter controle do território. Salvador torna-se então a primeira capital do Brasil. A cidade estaria localizada em um ponto estratégico, situada em equilíbrio em relação à costa do Brasil, onde a navegação poderia ser feita facilmente pelo norte e pelo sul, com uma localização que facilitava a defesa de outros pontos de ataque no território. Foi situada no alto de uma escarpa, onde até hoje estão os primeiros 
edifícios administrativos em torno de uma praça, a praça do poder político (OLIVEIRA in BARBIEIRI, 2010).

Sérgio Buarque de Holanda, em Raízes do Brasil, traz a observação lamentosa de Vilhena ${ }^{16}$ quanto a escolha dos portugueses para edificação da cidade de Salvador, que situada no alto de uma colina escarpada "cheia de tantas quebras e ladeiras" poderiam ter escolhido um sítio que a pouca distância poderia ser talvez um dos "melhores que haja no mundo para fundar uma cidade, a mais forte, a mais deliciosa e livre de mil incômodos" (Vilhena,1921 apud Holanda 1995) comparada a esta que esta localizada. A observação de Vilhena (1921) desconsidera a questão do ponto estratégico para uso da navegação e defesa do território, avaliado pelos portugueses, confirmando o pensamento de Holanda (1995) sobre as atividades colonizadoras portuguesas que observam a rotina e sugestões da topografia.

Salvador apresenta um aspecto em seu desenho urbano que pode ser comparado às antigas cidades-estados gregas, as polis. Estas se originavam em altas colinas, eram refúgios dos homens do campo e local de defesa dos inimigos e favoráveis ao tráfico marítimo e apresentavam, devido a sua topografia singular, o que conhecemos por cidade-alta e cidade-baixa, a primeira relacionada à acrópole- onde ficavam os templos dos deuses e segunda à astu - onde se desenvolviam o comércio e as relações civis, e que funcionavam como um todo único.

Planejada em Portugal, desenhada e readequada de acordo com a realidade do terreno, Salvador é uma cidade criada com critérios urbanísticos (REIS in BARBIEIRI, 2010), sua arquitetura é o reflexo do poder e dominação, do comércio da cana-de-açúcar e da mão escrava explorada dos milhares de africanos vindos de diversas regiões da África. Em suas manifestações culturais temos a síntese das culturas africanas e europeias.

\footnotetext{
${ }^{16}$ Luís dos Santos Vilhena, Recopilação das notícias soteropolitanas brasílicas, I (Bahia, 1921), p. 109
} 
Figura 08: Ilustração antiga da cidade de Salvador

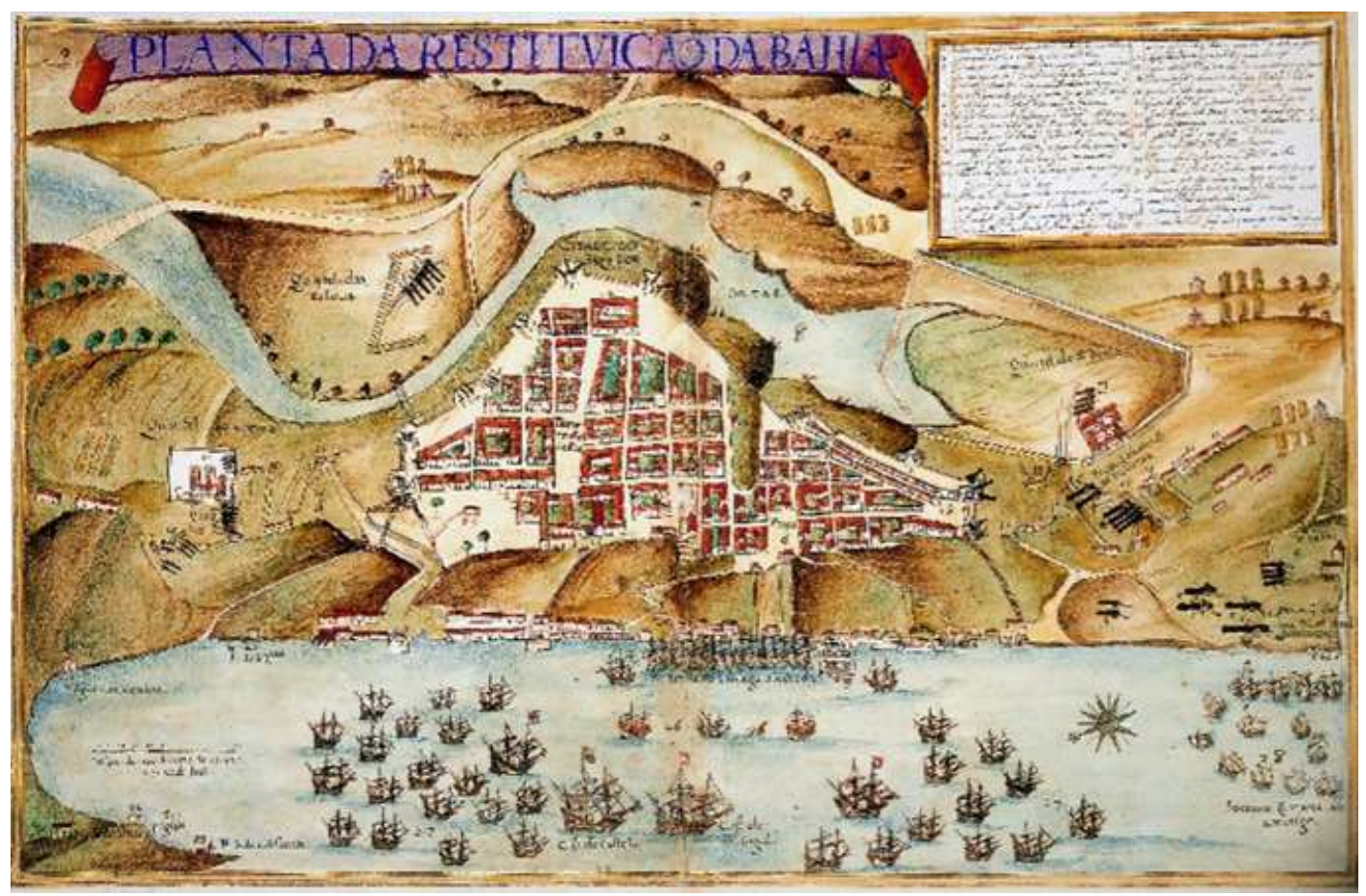

Fonte: http://www.sudoestesp.com.br/file/colecao-imagens-periodo-colonial-bahia/671(2014)

Figura 09: Ilustração antiga da cidade de Salvador

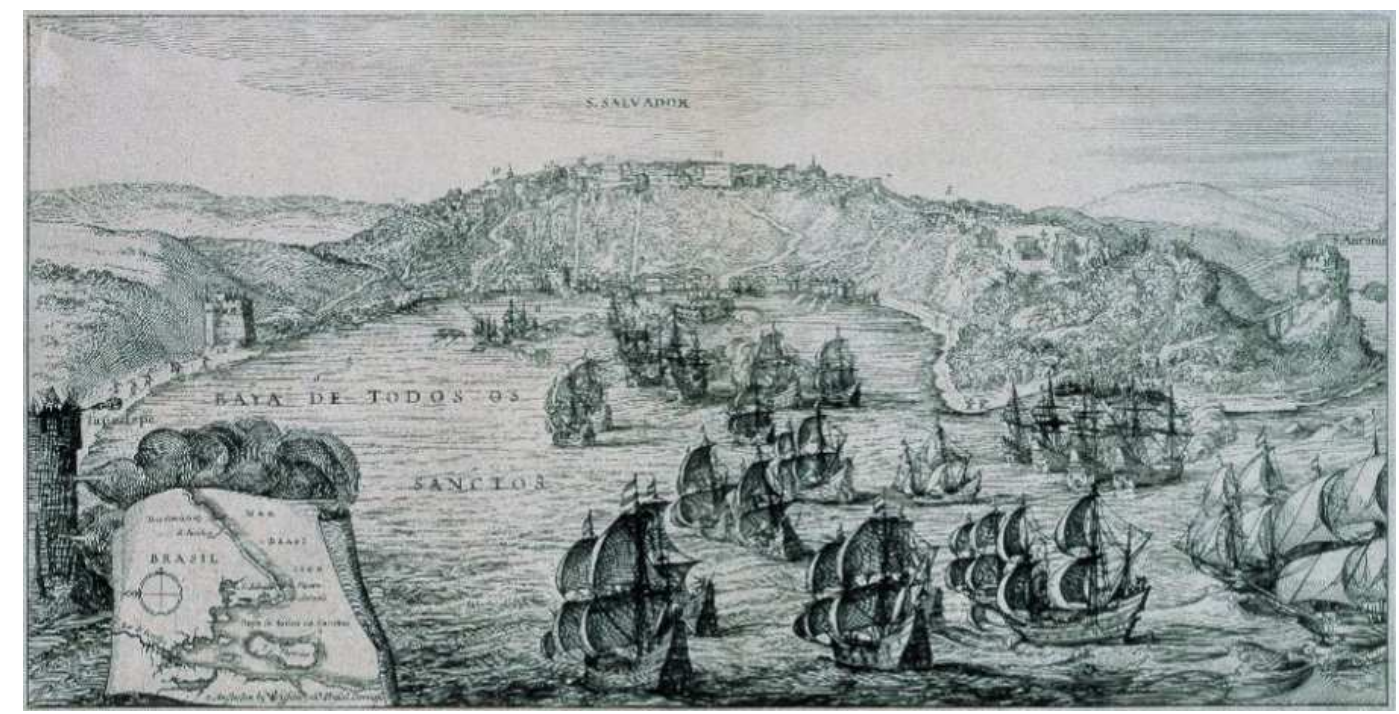

Fonte: http://www.sudoestesp.com.br/file/colecao-imagens-periodo-colonial-bahia/671/ (2014) 
Figura 10: Cidade baixa de Salvador

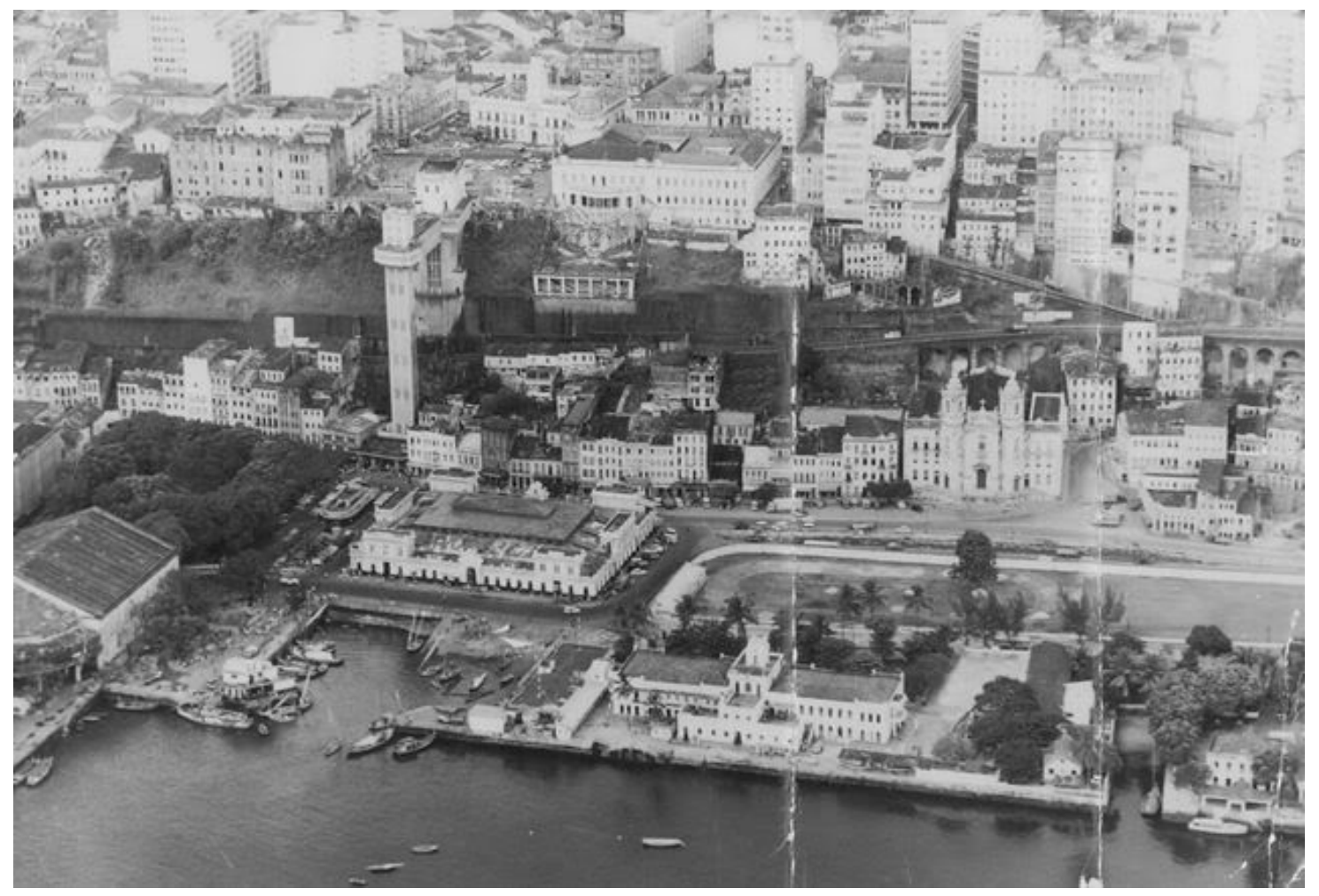

Fonte: http://www.skyscrapercity.com/showthread.php?t=787574 (2014)

\section{O DESENHO URBANO: RECIFE}

O desenho da cidade de Recife está relacionado à presença de Maurício de Nassau, príncipe alemão, patrono das artes e das ciências, enviado pela Companhia das Índias ao Nordeste Brasileiro para governar durante a curta ocupação holandesa no Brasil, no séc. XVII, a região que hoje vai de Alagoas ao Maranhão, e que apresentavam terras ricas na produção de cana-de-açúcar.

Assim como na época renascentista onde artistas eram convocados a pensar a cidade, Maurício de Nassau convida artistas, cientistas, poetas ao nordeste brasileiro. Manda construir pontes e palácios, assim como um jardim botânico e um observatório astronômico. Com ele vêm os pintores holandeses, autores dos primeiros registros visuais das terras brasileiras Albert Eckhout e Frans Post, que criam um novo imaginário sobre o Brasil. 
Figura 11: Recife no ano de $1644^{17}$

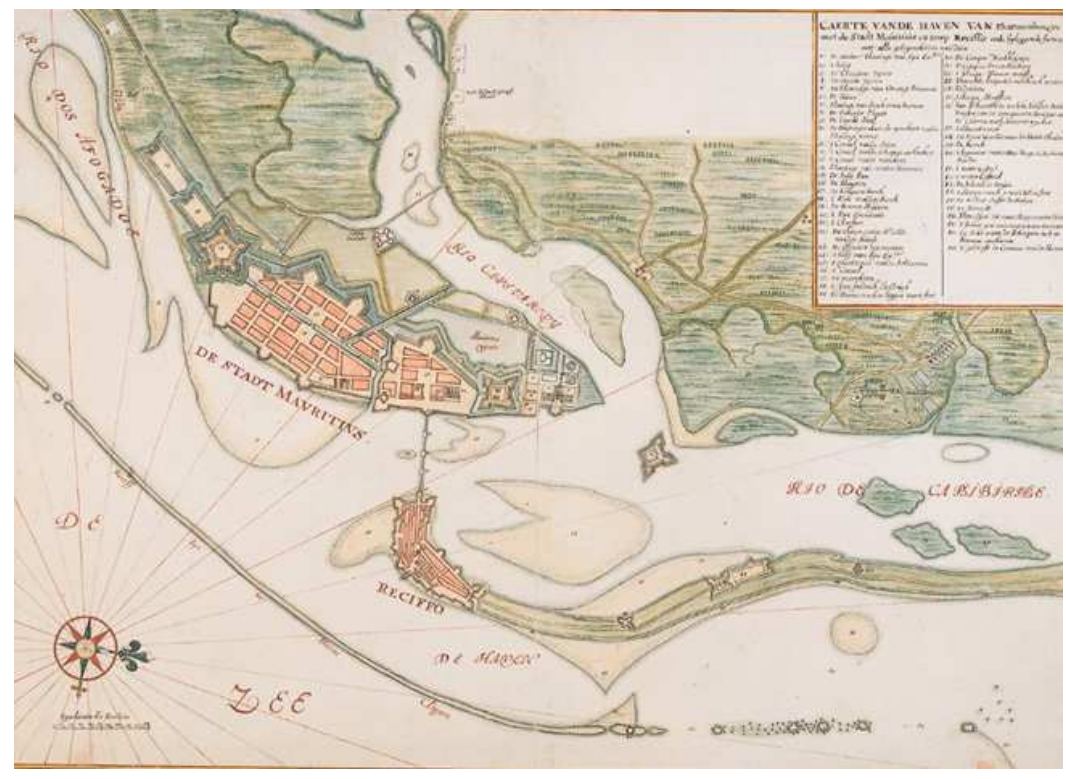

Fonte: http://www.sudoestesp.com.br (2014)

Figura 12: Paisagem com plantação (O Engenho), por Frans Post $(1668)^{18}$

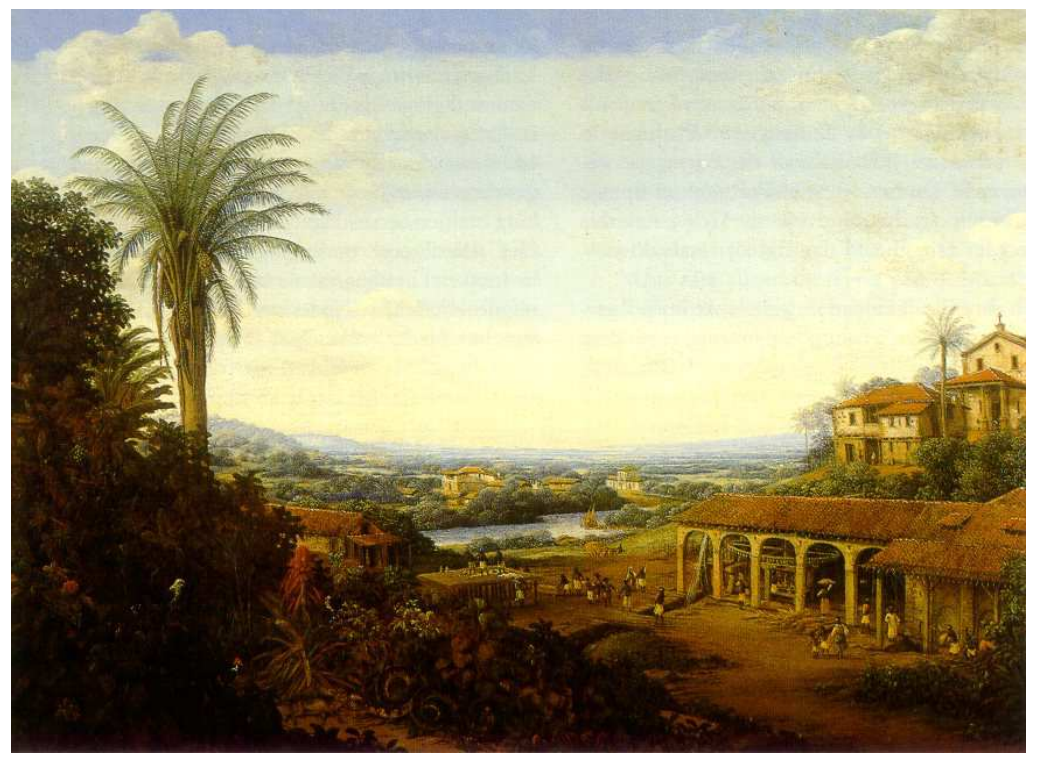

Fonte: http://people.ufpr.br/ lgeraldo/imagensengenhos.html (2014)

\footnotetext{
17 Trabalho de Cornelis Bastiaensz Golyath, cartógrafo holandês que trabalhou no Brasil, provavelmente entre 1635 e 1641. A imagem mostra os projetos para aperfeiçoamento do Recife, elaborados ao tempo de Nassau. Datado de 1644, vemos o palácio de Maurício de Nassau, com seus jardins na extremidade à direita, da Ilha de Antônio Vaz, e a parte ligando o bairro do Recife à ilha, concluída naquele ano. $\mathrm{O}$ plano para ampliação da Cidade Maurícia incluía um número maior de fileiras de quadras e uma praça central, dividida ao meio por um canal. http://www.sudoestesp.com.br

${ }^{18}$ Nesta imagem da segunda metade do século XVII observa-se o tripé constituído por engenho, casa grande e capela. Ao fundo, vêem-se casas dispersas na paisagem - moradias de escravos e de lavradores de cana radicados próximos aos engenhos. Nota-se também detalhes da vida de um engenho real, isto é, movido por roda d'água:casa de moenda, casa de purgar e batimento dos pães de açúcar ao ar livre. http://people.ufpr.br/ lgeraldo/imagensengenhos.html
} 
Nassau constrói pontes e edifica a capital Maurícia, planejada por Poust e destruída nas Batalhas de Tabocas e Guararapes (BARBIERI, 2010). O plano para a cidade Maurícia se assemelha a Amsterdã, onde o comércio passa por dentro dos canais e tem um traçado regular, como o primeiro traçado de Salvador. (BARBIERI, 2010).

Figura 13: Recife I, de Tarsila do Amaral (1925)

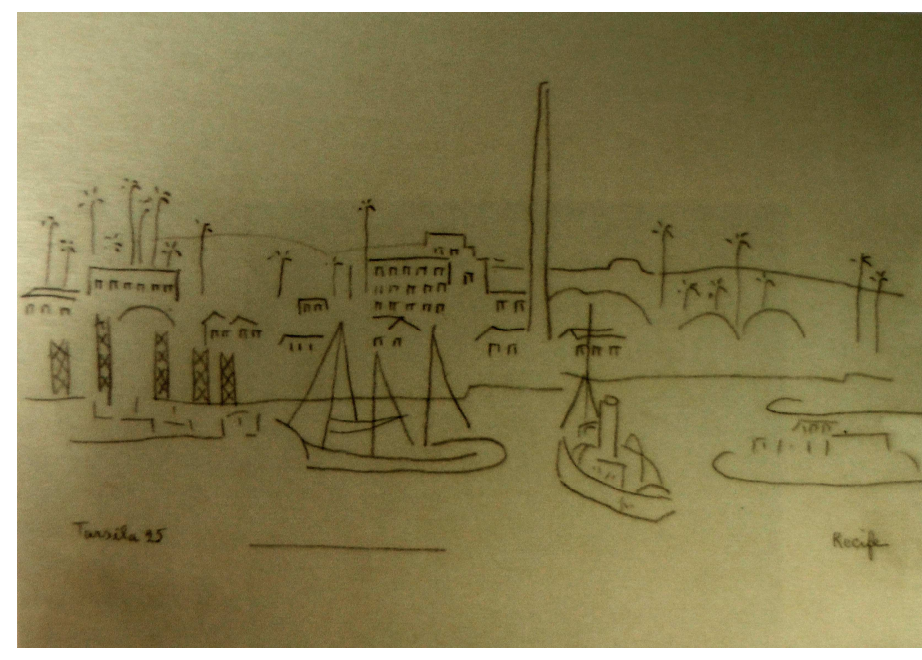

Fonte : Tarsila viajante (2008)

"Recife é uma cidade que nasce dentro d'água, é envolvida por uma belíssima paisagem que malgrado à má arquitetura, ainda os mangues, vez em quando cobrem, e esse sentido de liberdade, de céu aberto, de mar aberto, parece que está na anima" (MENEZES in BARBIEIRI, 2010).

Figura 14: Ponte Maurício de Nassau (fim do século XIX até meados do século XX)

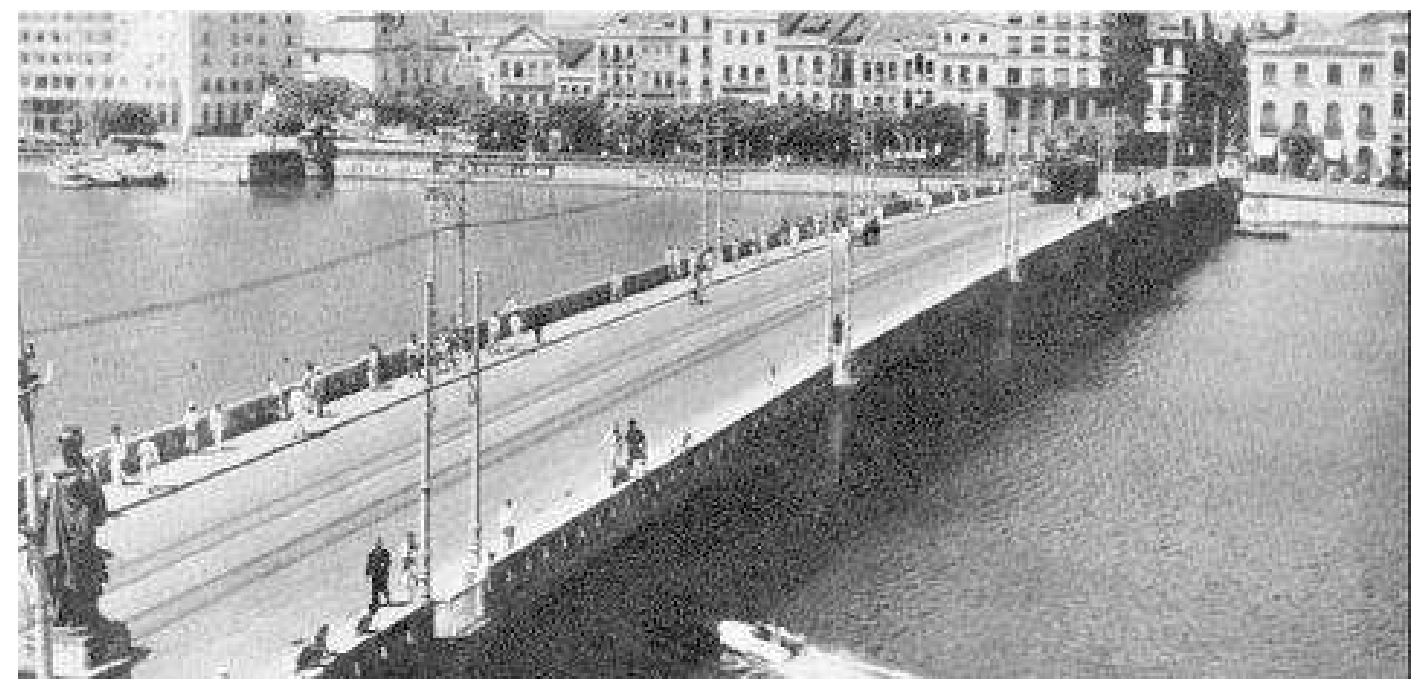

Fonte : http://www.skyscrapercity.com/showthread.php?t=479359 (2014) 
Assim, trazemos Salvador e Recife para exemplificar dois momentos na história do Brasil que por narrativas distintas, topografia particular e pensamento sobre a cidade, apresentam planificações diferenciadas, um tanto particulares, como é o caso também de Brasília, que veremos a seguir. Não é questão apresentar os desenhos das capitais do país, pois neste caso teríamos Recife substituída pelo Rio de Janeiro, mas sim apresentar as cidades por seus desenhos urbanos e pensamentos de concepção. Salvador aparece também como representação da impossibilidade de introdução do método cartesiano disponível na época para dar solução às cidades, ou seja, a incoerência do uso dos princípios de simetria e regularidade geométrica, importados da Europa. E Recife como criação quimérica de artistas e arquitetos, que como na Renascença eram convocados a pensar a cidade, mas que, infelizmente, não puderam ser construídas pelo falta de investimentos em programas urbanísticos. Os arquitetos trabalhavam em edifícios isolados enquanto as cidades passavam a "configurar as telas e as páginas dos artistas e escritores, permanecendo no âmbito da teoria, convertendo-se nas cidades ideais"

Figura 15 - Cidade Ideal - possivelmente de Fra Carnevale ${ }^{19}$

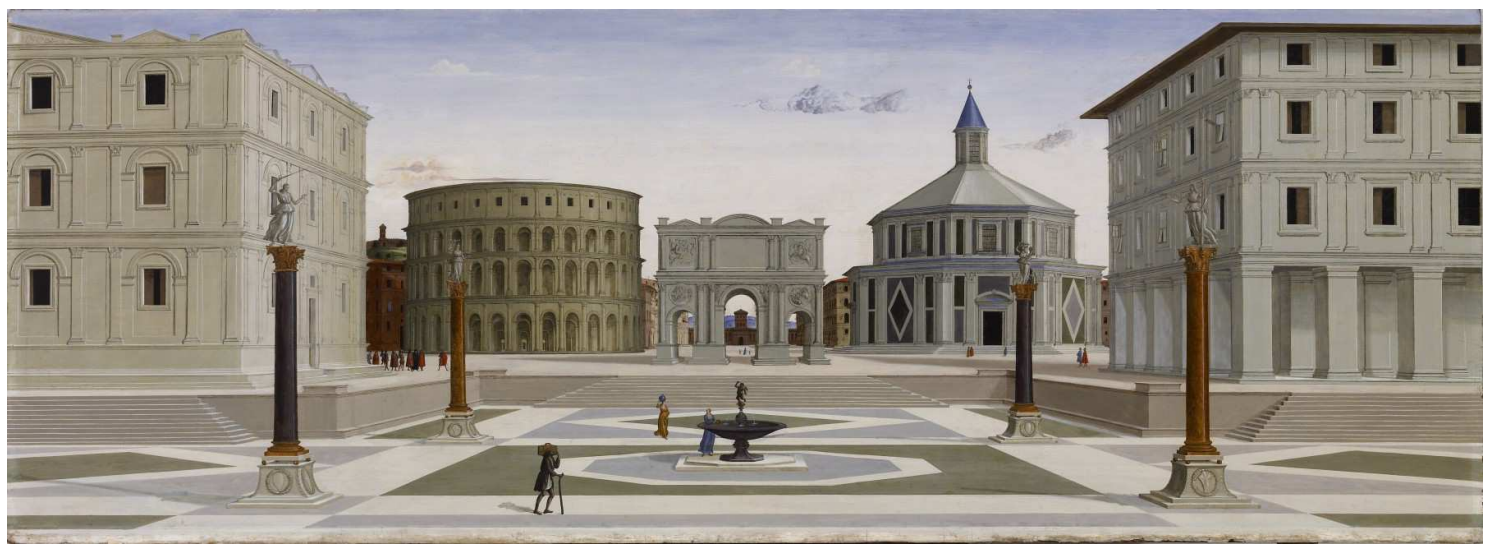

Fonte: HUMA3 Portal Internacional de Arte ${ }^{20}$

\footnotetext{
${ }^{19}$ Bartolomeo di Giovanni Corradini (1425 - 1485) conhecido como Fra Carnevale.

${ }^{20}$ Disponível no site http://www.huma3.com/huma3-eng-reviews-id-718.html, acessado em 21/01/2014
} 


\section{O DESENHO URBANO: BRASÍLIA}

Figura 16: Detalhe do Plano para a cidade de Brasília

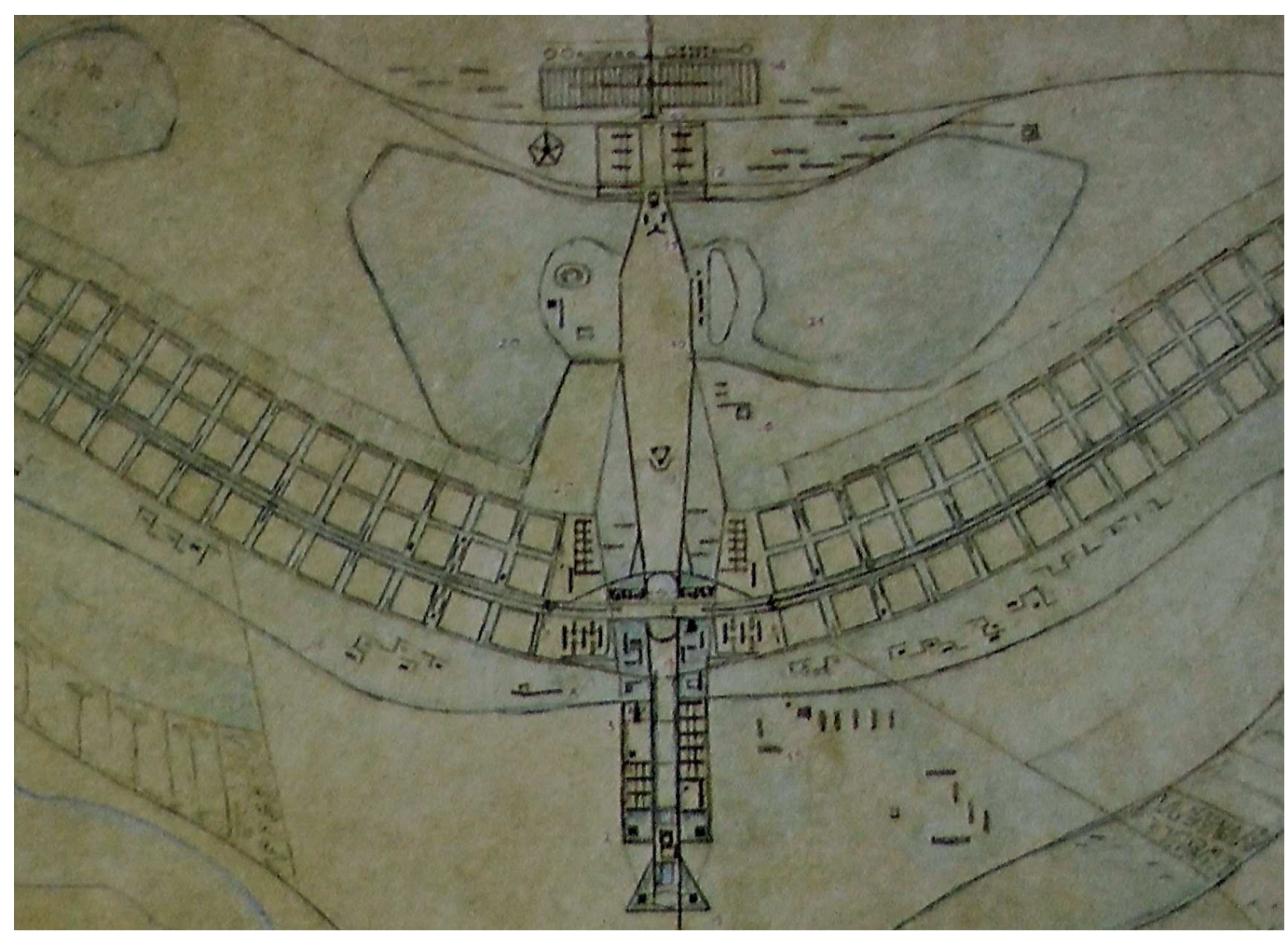

Fonte : Lucio Costa - Arquiteto (2010)

O histórico da construção da nova capital, Brasília, remonta a tempos longínquos. Desde o Brasil colônia "se falava em interiorização da capital, as condições de segurança sobrepunham-se a todas as demais". (TAMANINI, 2003). Cidades a beira mar não eram seguras, havia os ataques ocorridos em Salvador, e muitas vilas e cidades litorâneas eram constantemente atacadas e saqueadas. A própria perda de Pernambuco é um exemplo clássico da vulnerabilidade pela sua localização litorânea. Anseios de "progresso" e "civilização" e o desejo pelo aumento do comércio interno e desenvolvimento de riquezas já faziam parte do Brasil Império (TAMANINI, 2003) e mesmo depois da Independência do Brasil, no ano de 1822, a ideia da transferência da capital para o interior do país, seguia como obsessão pelos governos republicanos e por fim foi regulamentada no Artigo $3^{\circ}$ da Constituição da República Federativa dos Estados Unidos do Brasil de 1891 que dizia: 
Nós, os Representantes do Povo Brazileiro, reunidos em Congresso Constituinte, para organizar um regime livre e democrático e promulgamos a seguinte:

CONSTITUIÇÃO DA REPÚBLICA FEDERATIVA DOS ESTADOS UNIDOS DO BRASIL

TÍTULO PRIMEIRO

Da Organização federal

Disposições Preliminares

Arti $1^{\circ}$ - A Nação Brazileira adopta cômo forma de governo, sob regimento representativo, a República Federativa proclamada a 15 de novembro de 1889 , e constitue-se, por união perpétua e indissolúvel das antigas províncias, em Estados Unidos do Brazil.

Art. $2^{\circ}$ - Cada uma das antigas províncias formará um Estado, e o antigo município neutro constituirá o Distrito Federal, continuando a ser a capital da União, enquanto não se der execução do artigo seguinte.

Art $3^{\circ}$ - Fica pertencendo à União, no planalto cental da República, uma zona de 14.480 kilomentros quadrados, que será oportunamente demarcada, para nela estabelecer-se a Capital Federal.

Parágrafo Único. Effectuada a mudança da Capital, o actual Distrito federal passará a constituir um Estado

Entre os anos de 1892 e 1894, foram criadas duas missões exploratórias, as chamadas Missões Cruls, para definição, demarcação e indicação do local para estabelecimento da futura Capital Federal, de acordo com a Constituição acima citada, sob o comando do astrônomo belga Luis Cruls. A área indicada pelo paisagista e botânico Auguste Glaziou, integrante da Missão Cruls, se situava no Planalto Central, e foi descrita como "um platô formado por rochas cristalinas que se estende por todo o Centro-Oeste". A vegetação era de Cerrado, uma savana onde "predominam gramíneas, arbustos e, em menor proporção, pequenas árvores de caule retorcido, com folhas grandes e rígidas e raízes longas, que lhes permitem resistir ao rigoroso período de seca que se segue à estação de chuvas" (STENZEL e DORFMAN, 2010 apud WESELY, 2010). "Estudando tudo (...) impressionou-me profundamente a calma severa e majestosa desse vale" ${ }^{21}$, com abundância de recursos hídricos, minerais, vegetais e animais, onde culturas indígenas do grupo macro-jê habitavam há mais de 4 mil anos. No entanto a ideia da mudança foi esquecida na primeira metade do século $\mathrm{XX}$ e somente começou a tomar força novamente na chamada Marcha para o Oeste, do

\footnotetext{
${ }^{21}$ Auguste François Marie Glaziou em relatório sobre a segunda Missão Cruls, 1893, in Arquivo Brasília de Lina Kim e Michael Wesely, 2010.
} 
governo de Getúlio Vargas para ocupação do território brasileiro e fundações de novas cidades. (STENZEL e DORFMAN, 2010 apud WESELY, 2010).

Figura 17: Equipe da Missão Cruls (Final do Século XIX)

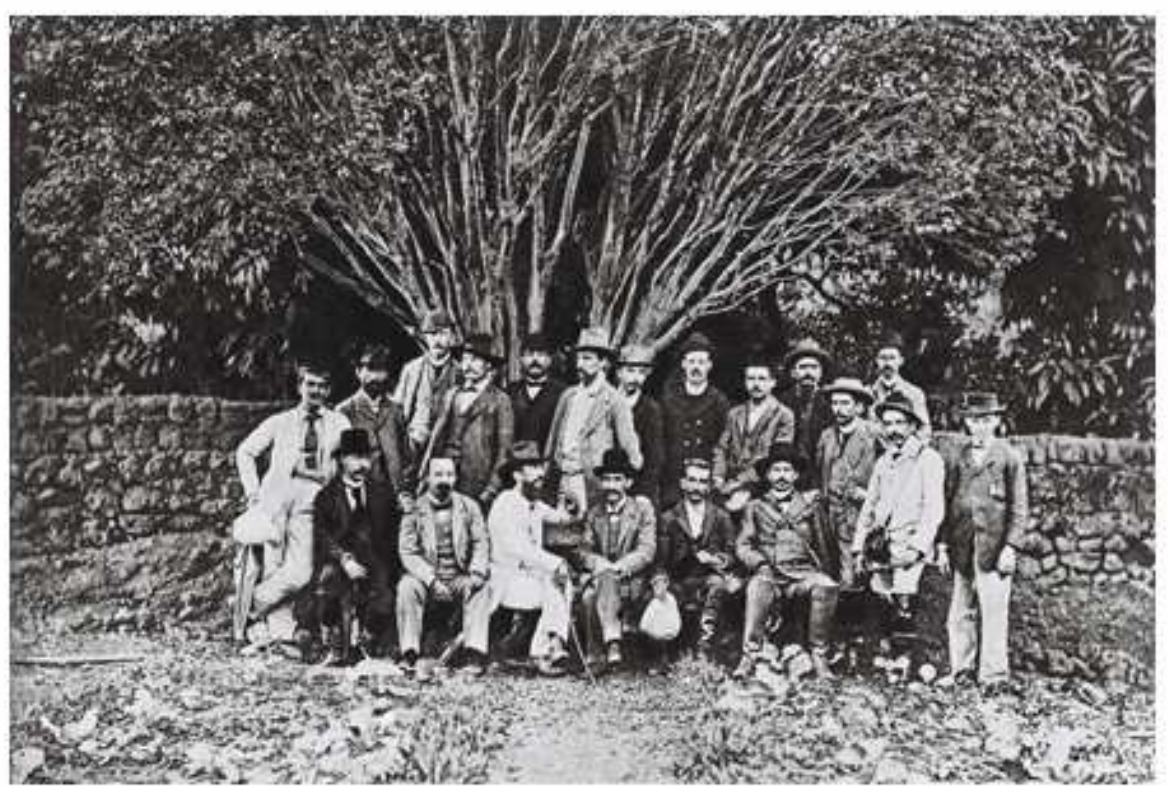

Fonte: http://www.senado.gov.br/noticias/especiais/brasilia50anos/not02.asp (2014)

Figura 18: Integrantes da Missão Cruls às Margens do Rio das Almas, em Goiás, 1892

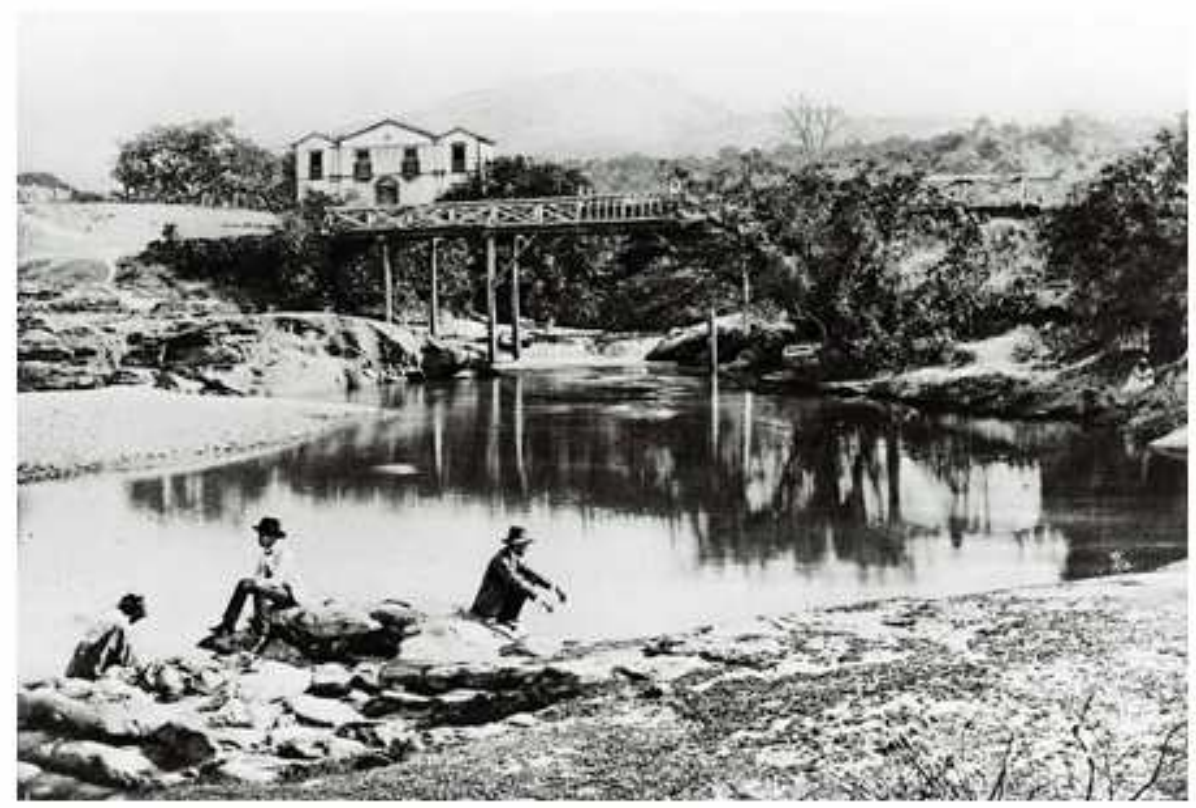

Fonte: http://www.senado.gov.br/noticias/especiais/brasilia50anos/not02.asp (2014) 
Finalmente, foi no governo de Juscelino Kubitschek (1956 - 1961) que a oportunidade da construção da nova capital foi exercida e a transferência da Capital do Brasil, na época o Rio de Janeiro, aconteceu. A realização de Brasília pertencia ao Plano de aceleração do desenvolvimento nacional, estabelecido em 1956 (50 anos em 5) e com ela, o Brasil moderno começava tomar forma concreta. O objetivo da sua criação seguia as indicações iniciais, com o foco na integração de diversas regiões e ocupações dos vazios no interior do Brasil. Essa transferência foi vista por uns com otimismo e por outros com desconfiança nos setores da política e da sociedade, havia a descrença de que uma ideia secular realizar-se-ia em 3 anos e 10 meses, conforme era a proposta, mas ao mesmo tempo existia a possibilidade de uma sonhada modernização e desenvolvimento do país. Brasília foi construída por trabalhadores vindos de vários Estados brasileiros que ali se estabeleceram, caracterizando a diversidade de culturas, tornando-se a representação da mistura de todo povo brasileiro.

Juscelino Kubitschek que desde a criação da Pampulha, mostrava preocupação com a estética das suas invenções urbanas, não sem razão foi considerado por Oscar Niemeyer "um príncipe da Renascença". Comenta Niemeyer, no documentário "A vida é um sopro" de Fabiano Maciel (2007) que se houvesse tempo, ainda viriam na época da construção artistas para pintar as edificações da cidade. Deste modo, similar a Maurício de Nassau, o presidente $\mathrm{JK}$ apreciara profissionais relacionados à arte para compor a estrutura estética da cidade, primando por uma construção que dialogasse com o momento artístico vivenciado na época, o modernismo.

\footnotetext{
Que cidade nasce em meio a tanta poesia e tanta arte? Oscar Niemeyer, poeta da curva; Burle Marx, poeta do paisagismo, Lucio Costa que faz o projeto, a certidão de nascimento de Brasília com poesia, revisado por Carlos Drummond de Andrade; as primeiras visitas: Tom Jobim e Vinícius de Moraes, para fazer a Sinfonia de Brasília, onde criam a primeira música que a cidade inspirou, sob uma nascente no Catetinho ${ }^{22}$
}

A construção de Brasília está associada ao modernismo brasileiro em duas vertentes, a de impulso desenvolvimentista de JK e pelo momento artístico que desde o

\footnotetext{
${ }^{22}$ José Benedito Fonteles é artista plástico, jornalista, editor, escritor, poeta e compositor. No trecho discorre sobre a música de Tom Jobim e Vinícius de Moraes, Água de Beber, que foi composta em visita ao Catetinho, para concepção de uma Sinfonia em homenagem à Brasília - A Sinfonia da Alvorada. Durante os dias da visita, os dois viram a fonte de água nascente que existe ainda hoje no local e questionando sobre ela receberam a seguinte resposta: "Essa é água de beber, camará", frase que inspirou a criação da composição in Sob o Signo da Poesia - documentário de Neto Borges.
} 
século XIX se expandia na Europa, onde no Brasil artistas e arquitetos refletiram sobre a realidade do país e renovação cultural no país.

As obras em Brasília começaram imediatamente, em 1956, mesmo antes de definido o plano urbanístico para a cidade. "A opção pelo concurso nacional de projetos para a Capital Federal resulta de uma soma de fatores. De um lado, é decorrência das pressões internas feitas pela categoria de arquitetos de todo país, em nome do seu órgão de representação legal - o Instituto de Arquitetos do Brasil (IAB) -, contra o possível convite de Le Corbusieur, que tinha inicialmente o apoio de personalidades importantes, tais como Affonso Eduardo Reidy e Roberto Burle Marx. De outro lado conta-se que Juscelino chegara a convidar Oscar Niemeyer para elaborar o projeto da cidade, e que este teria apontado Lucio Costa como figura mais indicada para o plano. Já Lucio teria sugerido a organização de um concurso nacional sob o patrocínio do IAB (BRAGA, 2010). O IAB envia ao governo o "Manifesto dos arquitetos ao presidente da República", em agosto de 1956, pedindo então um concurso de projetos para profissionais brasileiros, e em setembro é publicado o Edital do Concurso Nacional do Plano Piloto da Nova Capital do Brasil, ao mesmo tempo em que é criada a companhia encarregada da construção da cidade, a Companhia Urbanizadora da Nova Capital do Brasil (NOVACAP), presidida por Israel Pinheiro (BRAGA, 2010).

Dentre as 26 propostas apresentadas, sete foram premiadas e o prêmio de primeiro lugar foi dado ao projeto de Lucio Costa. "O júri era formado por seis membros, - renomados arquitetos, urbanistas e críticos de arte. O que viram foi, de início, constrangedor. Lucio Costa já era, à época, um dos grandes nomes da arquitetura brasileira. Mas os rabiscos toscos feitos a lápis de cor, pequenos desenhos a nanquim e um texto batido a máquina pareciam brincadeira de criança diante de maquetes, croquis, quadros de alumínio - recursos sofisticados que compunham os projetos já entregues. Uma semana depois, no dia 16 de março de 1957, o júri consagrou, dentre os vinte e cinco, o mais mal-apresentado dos projetos, um trabalho de feição amadora, sem um único cálculo. Sem equipe e com poucos desenhos, mas munido de um belíssimo memorial descritivo, o projeto de Lucio Costa foi considerado pelo júri o único adequado a uma capital. A proposta aliava monumentalidade e clareza. Na era do 
automóvel, suprimiu, com o uso de trevos, os cruzamentos nas vias. O poeta Carlos Drummond de Andrade ao ver os traços comentou "era um rabisco e pulsava" 23.

Para Lucio Costa o que de fato importava naquele momento era ter a configuração urbanística da cidade propriamente dita, pois esta não era decorrência de um planejamento regional, mas a sua causa. Sua construção seria, assim, "um ato deliberado de posse, um gesto ainda desbravador, nos moldes da tradição colonial". (BRAGA, 2010). No relatório do Júri, foram pontuadas algumas observações sobre a proposta apresentada por Lucio Costa, como, a idealização de uma cidade diferente de qualquer outra de quinhentos mil habitantes; sua funcionalidade e expressão arquitetural própria; sua principal característica sendo a função governamental onde em torno dela se agrupam todas as outras funções e para ela tudo converge. Considerou os dados topográficos, a extensão da cidade em relação com a densidade da população, a compreensão do plano que apresentava uma síntese arquitetônica geral e uma específica da sede do governo e estabeleceu a classificação segundo os aspectos funcional e plásticos, pois buscavam encontrar um projeto que apresentasse unidade e conferisse grandeza à cidade, pela clareza e hierarquia dos elementos (BRAGA, 2010)

A criação de Brasília foi uma decisão política a partir da qual uma cidade de importância relevante nasceria do zero no Planalto Central, uma invenção aonde antes não havia nenhuma construção urbana similar (REIS apud BARBIERE, 2010).

Figura 19: Desenho do primeiro traço para a cidade de Brasília, por Lucio Costa

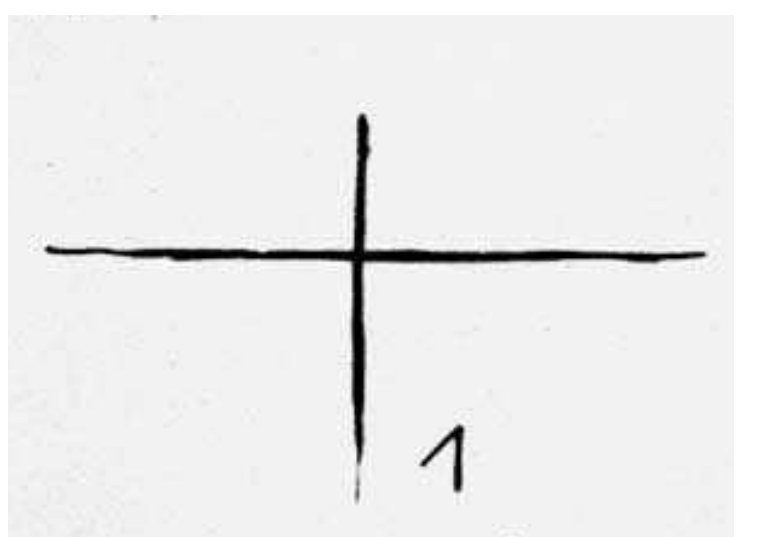

Fonte: O concurso de Brasília: sete projetos para uma capital (2010)

\footnotetext{
${ }^{23}$ Declaração disponível em http://veja.abril.com.br/especiais/brasilia/era-rabisco-pulsava-p-072.html. Acessado em maio de 2012.
} 
Figura 20: Fotografia do traço na paisagem.

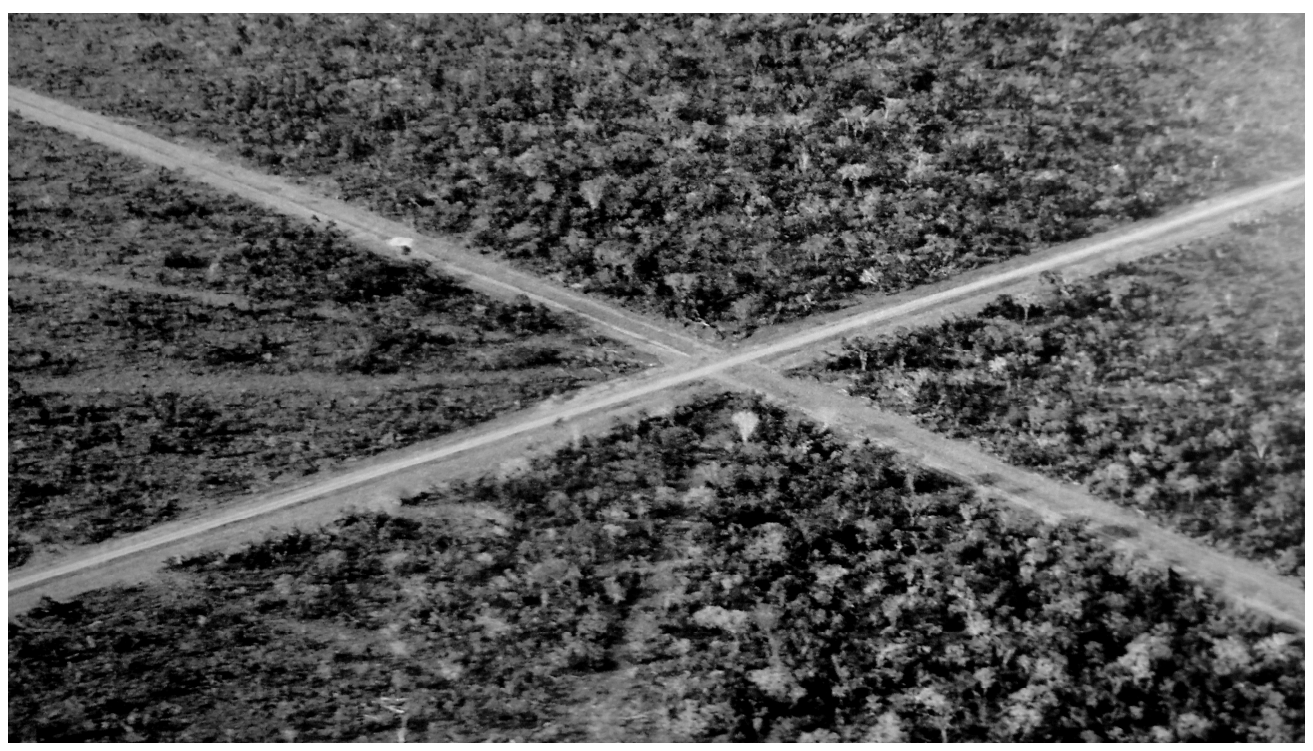

Fonte: O concurso de Brasília: sete projetos para uma capital (2010)

Figura 21: Onde se cruzam os eixos

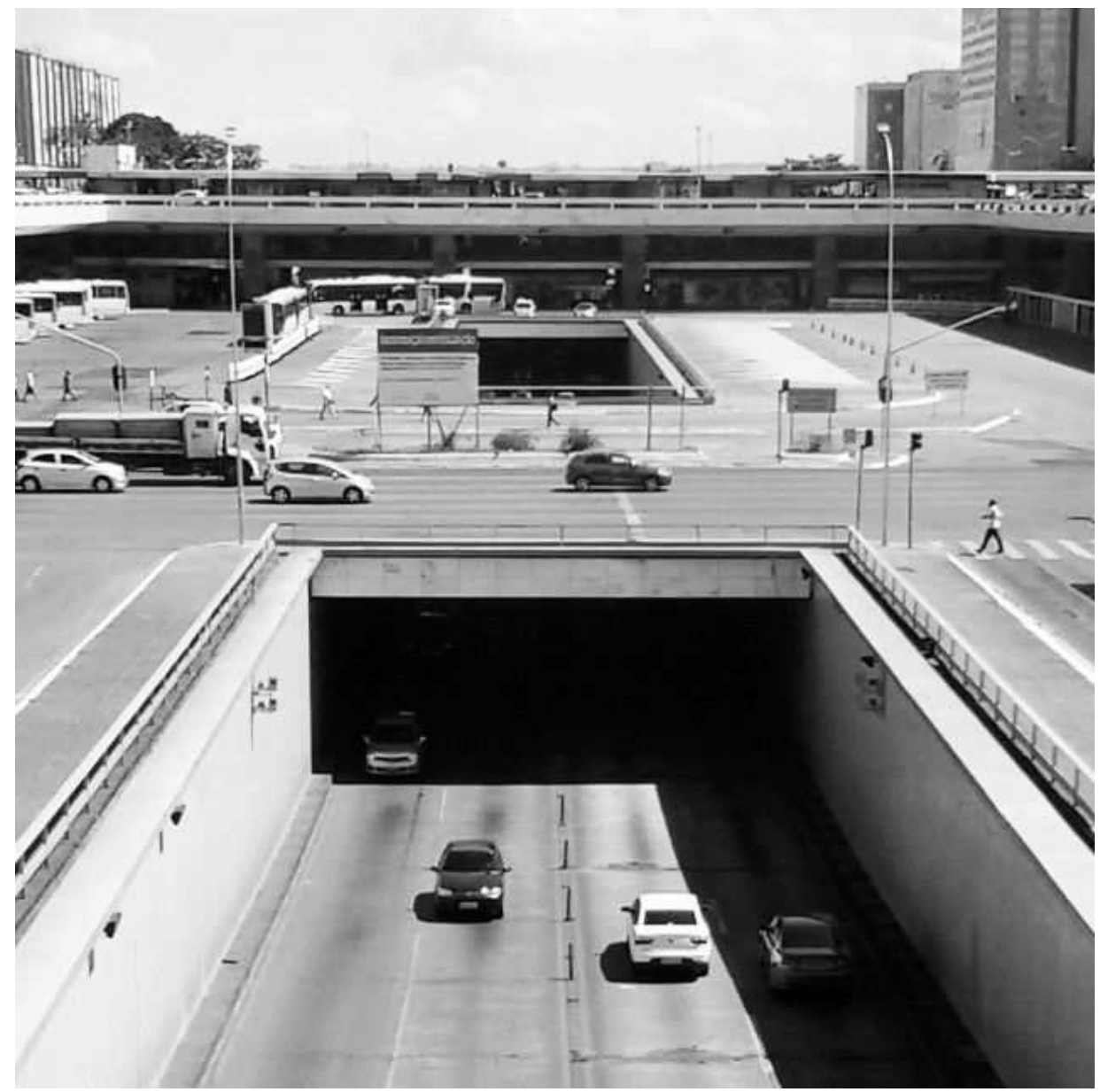

Fonte : Tatiana Terra (2015) 
Brasília é uma cidade que ainda hoje apresenta todo um diferencial pela concepção, proposta do urbanista Lucio Costa:

(...) a cidade tradicional é conhecida pelas suas ruas e pelas suas quadras, as ruas cercam as quadras e dentro das quadras, os lotes, então a relação entre o espaço público e o espaço privado, ela já vem pronta. Em Brasília isto desaparece completamente, os edifícios estão soltos no meio do gramado, no meio das árvores. Foi a maior cidade construída no mundo com modelo modernista, já com esses novos padrões, isso foi uma inovação total. (REIS apud BARBIERI, 2010)

O plano para a cidade de Brasília, desenhado por Lucio Costa começa com dois traços que como uma cruz, toma posse de um determinado lugar, são dois eixos que se cruzam, e logo um deles é arqueado para se adequar a topografia local.

No eixo que vai de Leste a Oeste, localiza-se o Eixo Monumental e nele estão dispostas as principais edificações públicas. O outro eixo, perpendicular, de Norte a Sul, localizam-se as residências e foi denominado Eixo Rodoviário-Residencial. Em torno desses dois eixos, se desenha todo funcionamento da cidade. Sua criação original "com seus eixos, suas perspectivas, sua ordance" (COSTA,2001) remete inconscientemente à cidade de Paris. Os terraplenos, os arrimos, os pavilhões com desenhos de implantação foram inspiradas em fotografias da China do começo do século XX, bem como inspiradoras também foram as auto-estradas de Nova York para o desenho de Brasília $^{24}$.n Na década de 80 , a cidade foi revista e reanalisada pelo seu idealizador e suas observações expressas em um documento histórico. É neste Documento de Lucio Costa escrito entre os anos de 1985 e 1987, denominado Brasília Revisitada para Complementação, Preservação, Adensamento e Expansão urbana da cidade de Brasília, que ele apresenta as quatro escalas que traduzem sua concepção urbana: as escalas Monumental, Gregária, Residencial e Bucólica.

Lucio Costa não tinha intenção de se restringir a apenas duas escalas: a Monumental para os centros do poder, e a Residencial para as habitações coletivas dos funcionários públicos, assim ele acrescenta duas novas escalas: a Gregária para o centro da cidade, e a Bucólica para criar espaços verdes livres e não ocupados (COSTA, 2011).

Para esta investigação que contempla o caminhar na Entrequadras de Brasília, abordaremos duas escalas, a Residencial e a Bucólica.

\footnotetext{
${ }^{24}$ Registro de uma vivência in Com a palavra, Lucio Costa.
} 
Figuras 22: Vista aérea do Plano Piloto

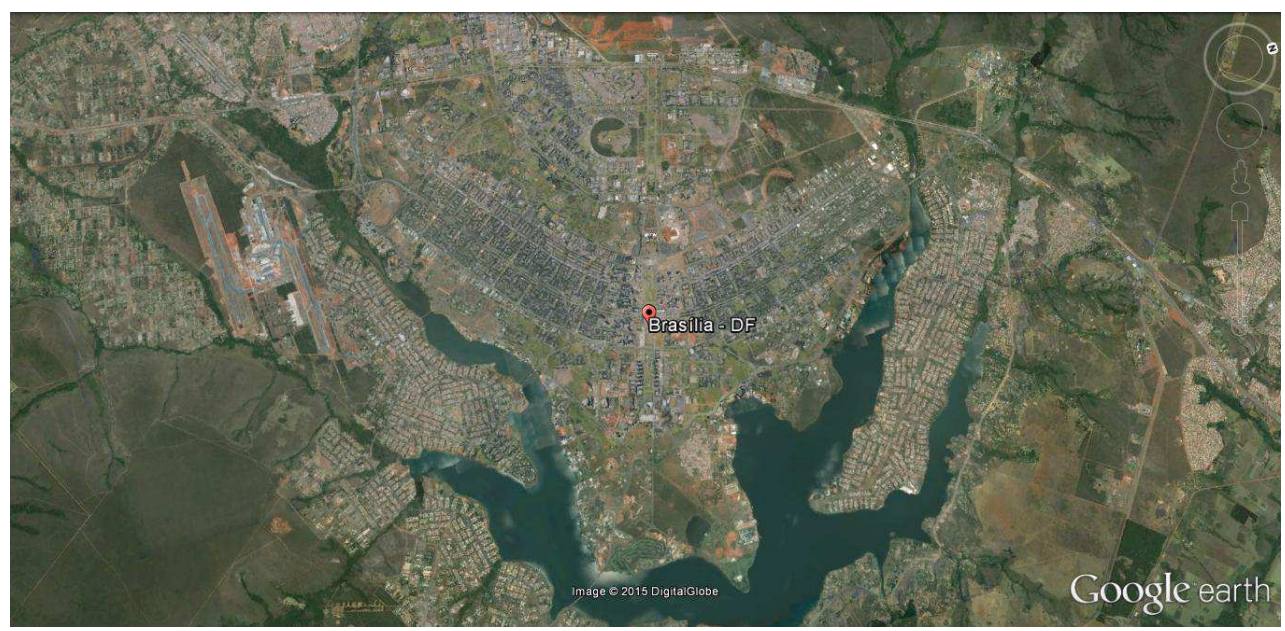

Fonte: Google Earth (2015)

Figuras 23: Vista aérea do Eixo Monumental

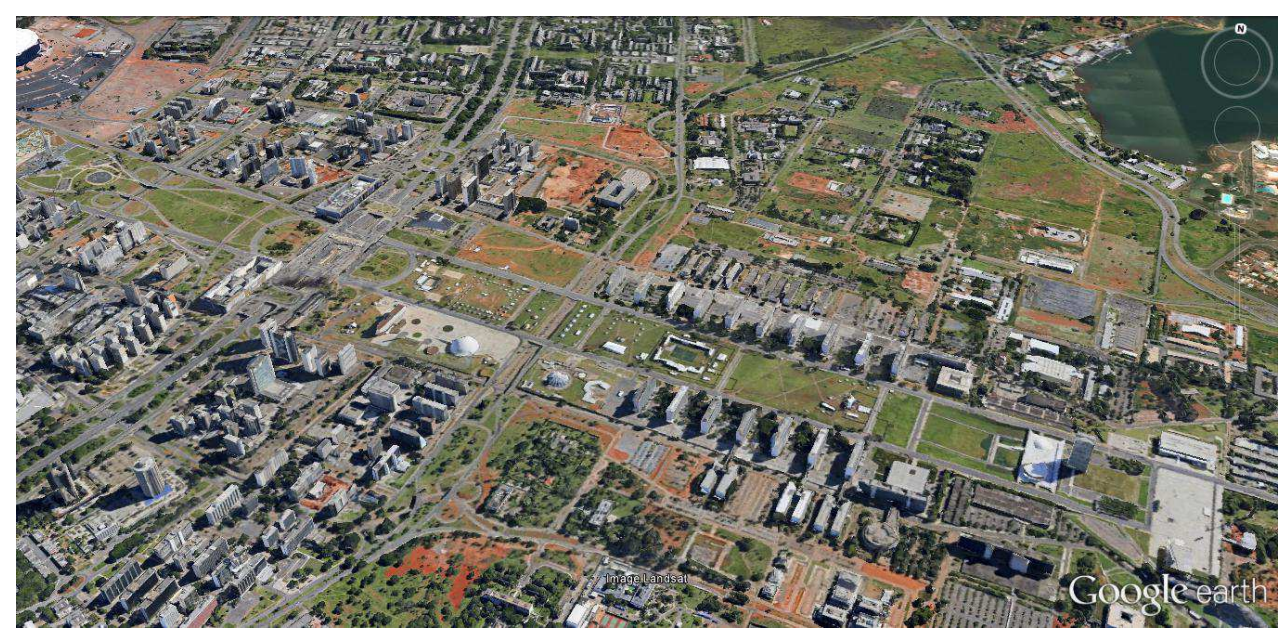

Fonte: Google Earth (2015)

Figuras 24: Vista aérea da Escala Gregária

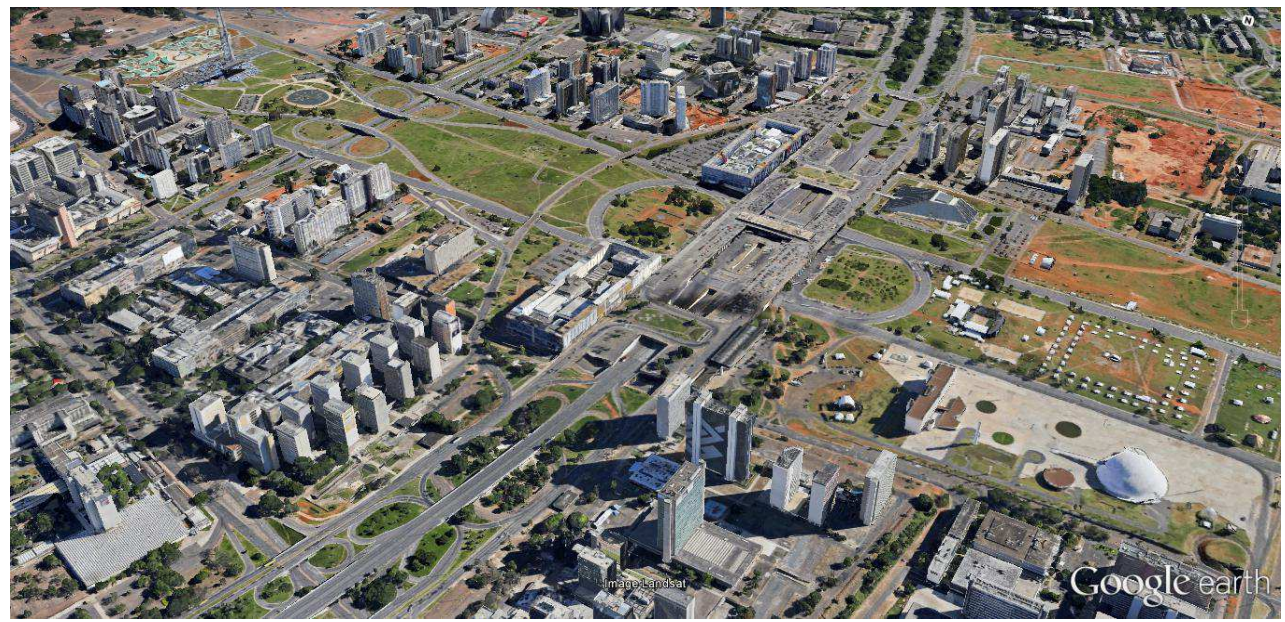

Fonte: Google Earth (2015) 
Figuras 25: Vista aérea das Quadras e Entrequadras cortadas pelo Eixo Rodoviário Residencial

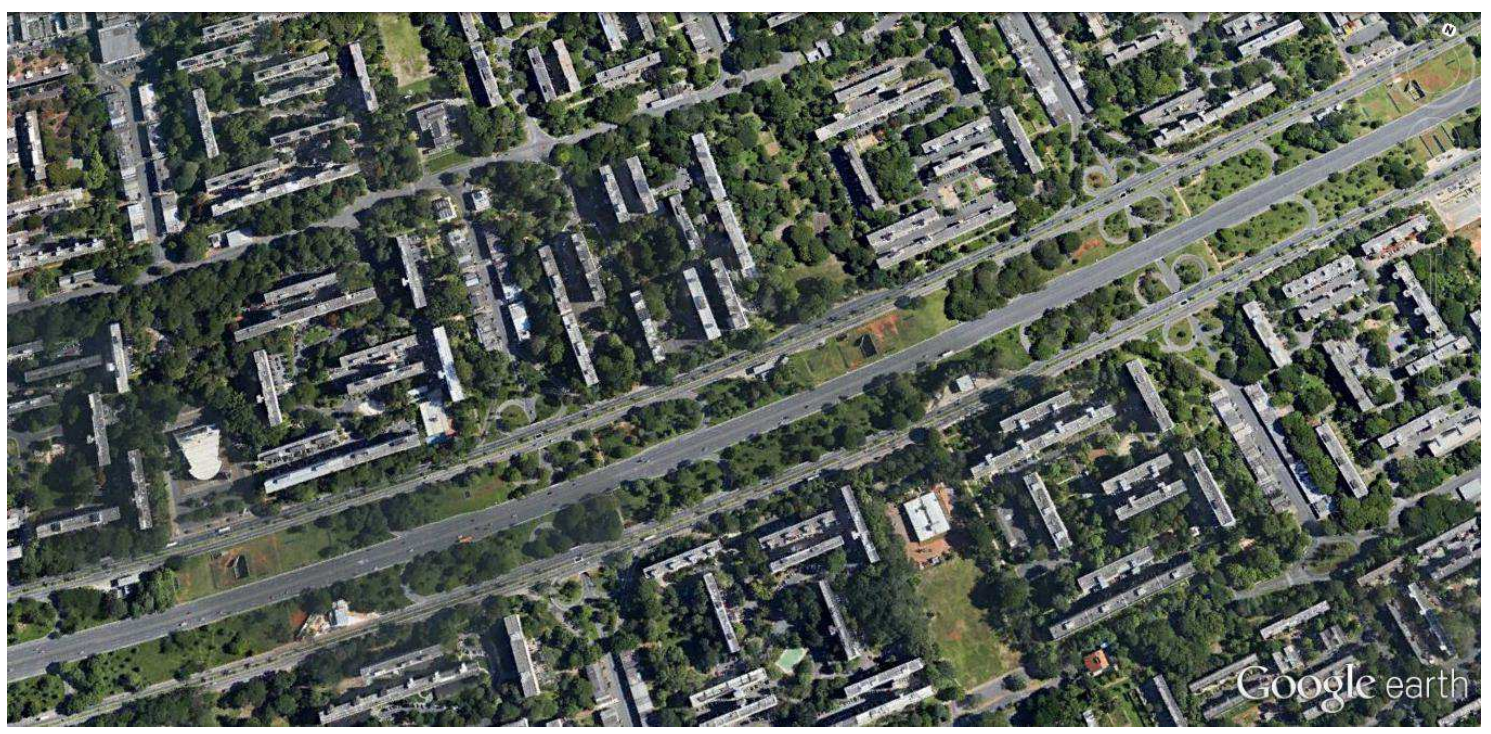

Fonte: Google Earth (2015)

Figuras 26: Vista aérea do Plano Piloto e Lago Paranoá

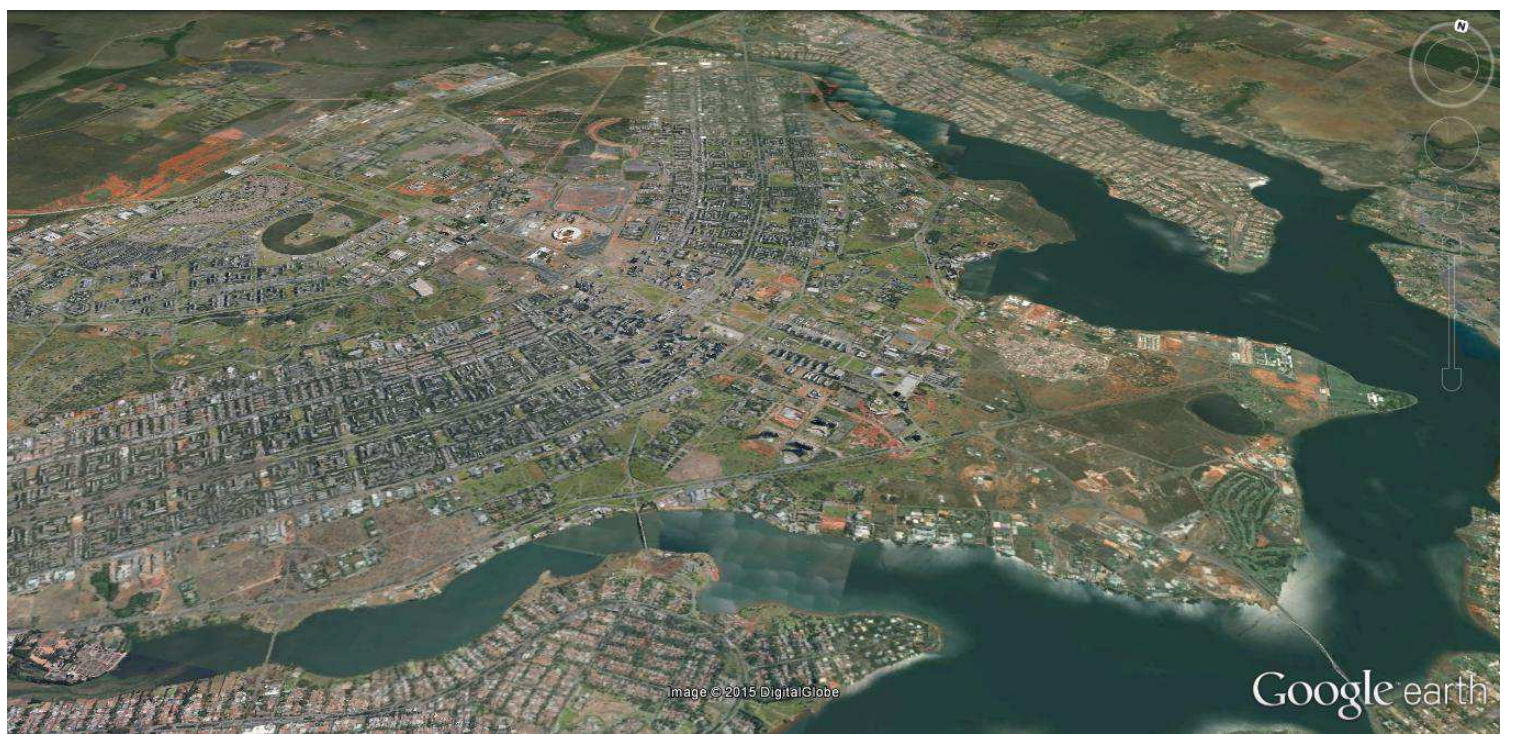

Fonte: Google Earth (2015) 


\section{AS ESCALAS BUCÓLICA E RESIDENCIAL DE BRASÍLIA}

Figura 27: Escalas Monumental, Gregária, Residencial e Bucólica

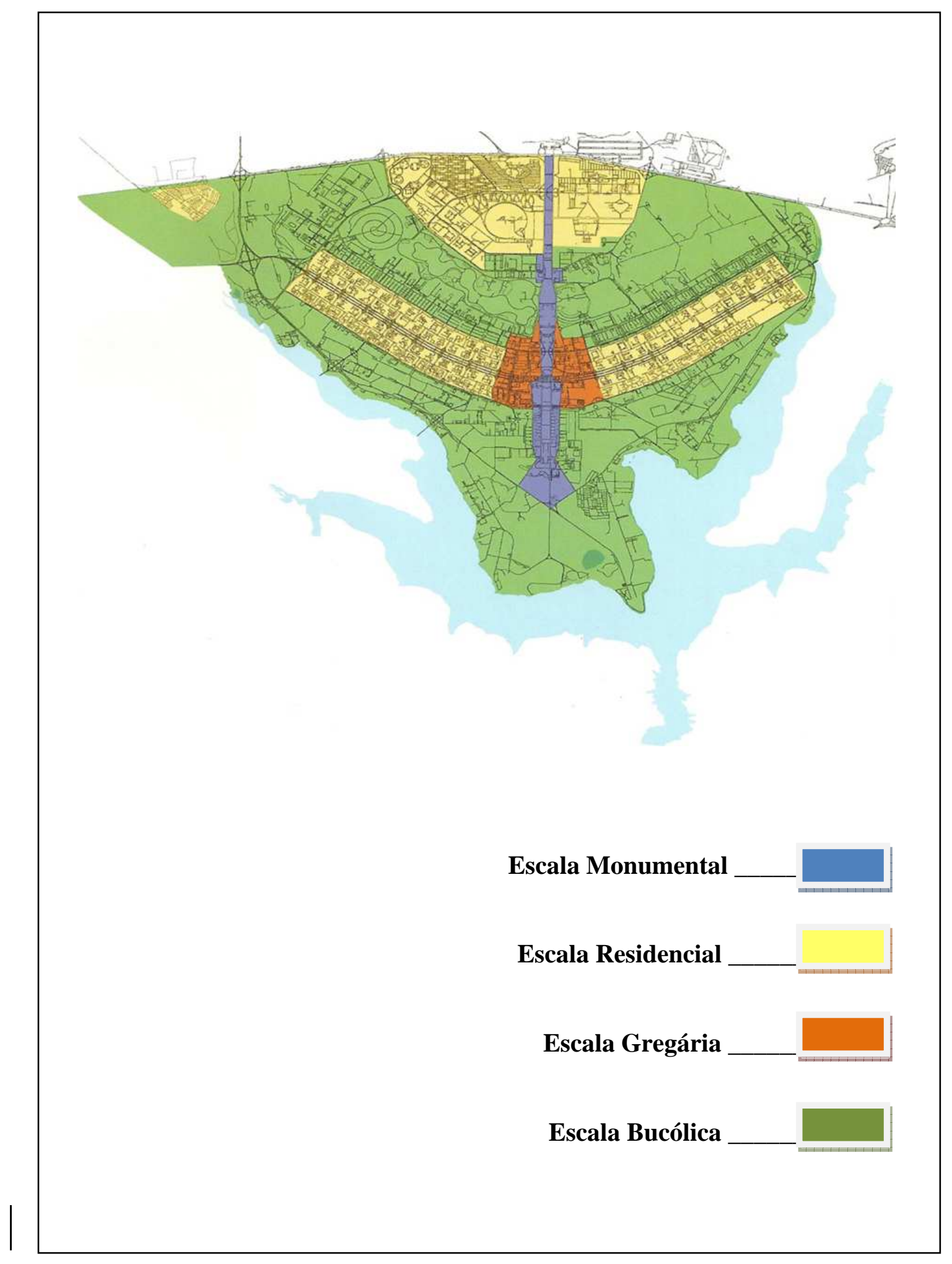

Fonte: Plano Piloto 50 anos: cartilha de preservação 
A partir da definição destes dois eixos estruturadores, "desarmado de preconceitos e tabus urbanísticos e imbuído da dignidade implícita de inventar a capital definitiva do país" (COSTA, 2001), Lucio Costa planejou uma paisagem urbana articulada por quatro escalas espaciais: a Escala Monumental, que configura a cidade em sua função de capital do país, onde se concentra a visitação turística da cidade, pois além de localizar as representações cívicas da Capital, estão ali os principais edifícios arquitetônicos construídos pelo arquiteto Oscar Niemeyer; a Escala Residencial, que orienta a constituição das Superquadras; a Escala Gregária, que orienta a disposição das áreas comerciais e de lazer do centro da cidade; e a Escala Bucólica, que orienta a definição do complexo de parques e de áreas verdes de baixa densidade às margens do lago Paranoá e nas franjas do plano piloto. Essas escalas definem certas ênfases na configuração espacial e na distribuição das atividades urbanas que extrapolam os limites do zoneamento estrito, característica do modelo funcionalista e também presente em Brasília. Definindo um novo paradigma de ambiente urbano, elas conferem à paisagem da cidade uma qualidade estética que não se vislumbra no horizonte de outras grandes cidades do país (STENZEL e DORFMAN,2010 apud WESELY,2010). Nesta investigação, traz-se a proposta de visitação turística na Escala Residencial, onde o turista convencional e o turista cidadão podem conhecer e usufruir do espaço elaborado para o morador, o espaço de valor humanístico na cidade de idealização governamental.

Figura 28: Escala Residencial (permeada pela Escala Bucólica)

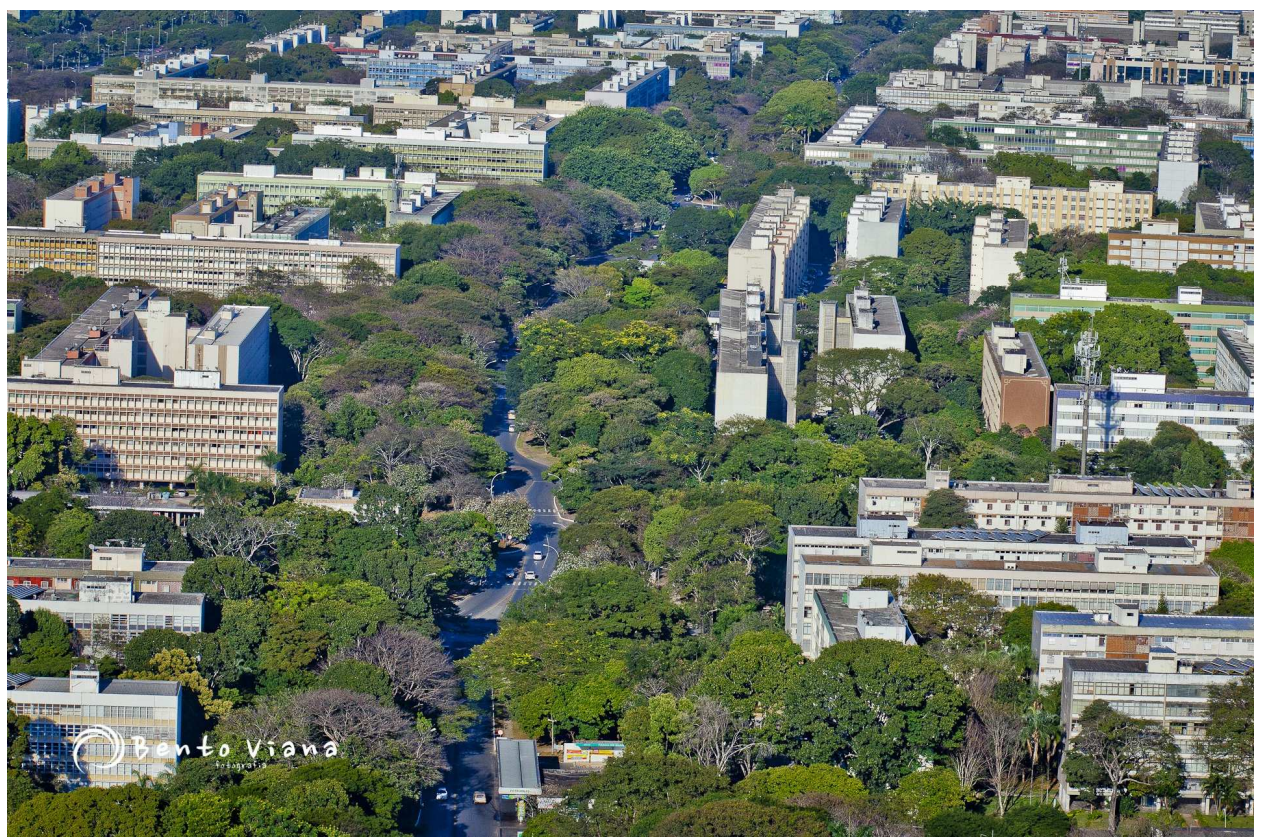

Fonte: Bento Vianna (2014) 
Ser uma cidade administrativa era requisito primordial do concurso para o Plano Piloto - mas Lucio Costa fez questão de considerar o ser humano que habitaria a cidade, conforme exposto nos registros apontados no memorial descritivo que acompanhava os desenhos para o projeto, entregue à comissão do júri como proposta urbanística para a cidade. Brasília, para seu criador foi pensada para ser cidade viva, do trabalhador e habitante, seu desenho era imbuído de pensamento humanista. As linhas que pulsavam pertenciam a um sistema orgânico em um planejamento lírico. Para ele, a cidade deveria ser "derramada e concisa, bucólica e urbana, lírica e funcional" ${ }^{25}$, poesia que se vê em seus traços, expressa no ato de desenhar. Enquanto se risca, traça-se a linha "que pode separar, no processo de nossas percepções, o domínio das coisas materiais, dos acontecimentos cotidianos, das tendências razoáveis, do domínio mais particularmente reservado às reações de ordem espiritual. Abaixo das linhas: aquilo que é. Acima da linha: aquilo que sentimos ${ }^{26}$ (LE CORBUSIER, 2004).

As duas linhas iniciais que se cruzam dão a forma básica da cidade, e popularmente relacionam-na à forma de um avião. Mas "não tem nada de avião! É como se fosse uma borboleta..."27. Associar seu desenho a uma máquina não agradava seu criador. O cruzamento dos eixos demarcavam um lugar como posse e o arqueamento de um deles adequava-se a topografia da região. Este eixo arqueado que recebeu o nome de Eixo Rodoviário-Residencial, e pela coordenada geográfica, dividese em duas partes: norte e sul, denominadas Asa Norte e Asa Sul. Pertence à Escala Residencial e Bucólica, recortes desta investigação.

O outro eixo que dá corpo à cidade administrativa é o Eixo Monumental, e pertence à Escala Monumental. É onde se concentra o fluxo de turistas e por onde a cidade é constantemente apresentada e explorada iconograficamente. A quarta escala, a Escala Gregária, concentra os edifícios altos e os setores de Diversões, Comerciais, Autarquias, Bancários, Hoteleiros, Rádio e Televisão Sul e Norte e se localiza no centro da cidade, ao redor da intersecção dos dois eixos, monumental e rodoviário.

\footnotetext{
${ }^{25}$ Projeto de Lucio Costa disponível no site do IPHAN http://portal.iphan.gov.br/portal/baixaFcdAnexo.do?id=280

${ }^{26}$ Le Corbusier. As técnicas são a própria base do lirismo, elas abrem um novo ciclo da arquitetura. Precisões. Sobre um estado presente da arquitetura e do urbanismo, 2004, pg.47 (Edição original, 1930)

${ }^{27} \mathrm{http}$ //www.almanaquebrasil.com.br/curiosidades-historia/9312-a-capital-do-sonho.html 19/07/2013
} 
As Escalas Gregárias e Monumental não serão contempladas nesta investigação. Todas as características das quatro escalas, por Lei, se encontram em anexo - Decreto n ${ }^{\circ} 10.820$ / 87.

Figura 29: Edifícios na Escala Gregária

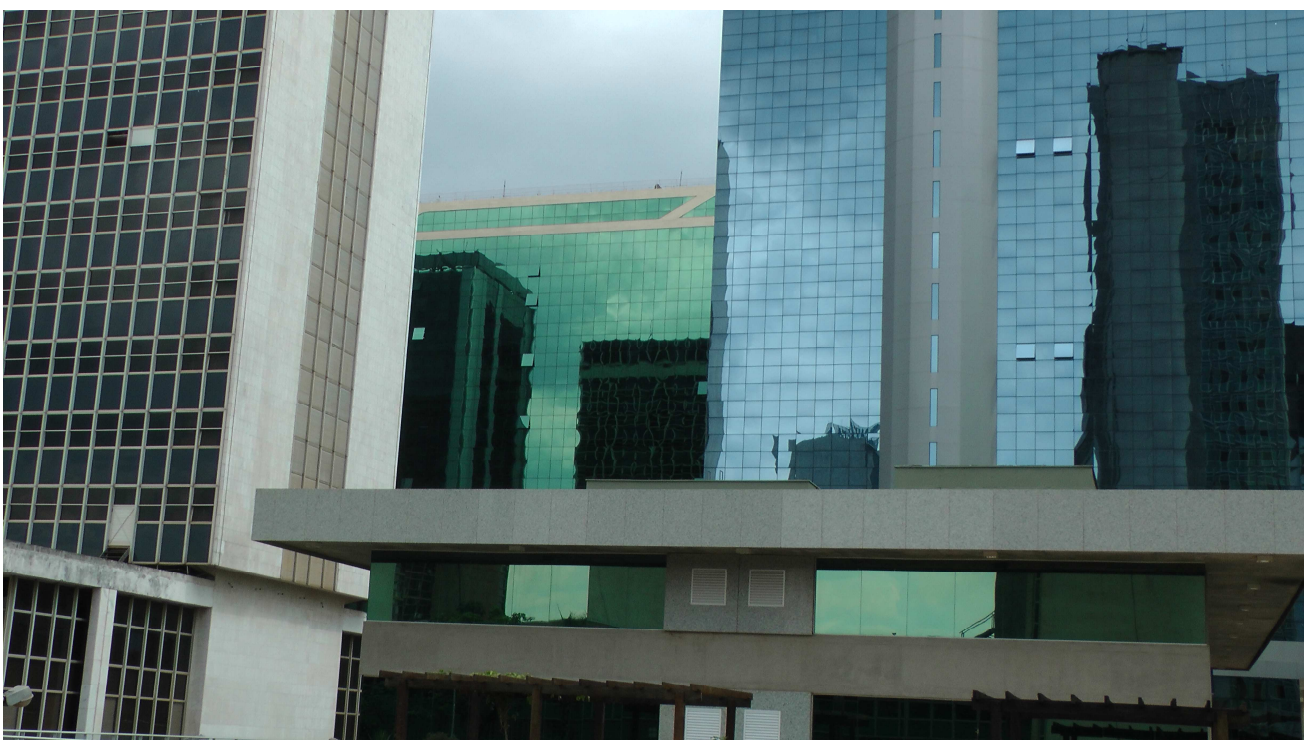

Fonte: Tatiana Terra (2013)

Figura 30: Turistas na cidade de Brasília - Escala Monumental

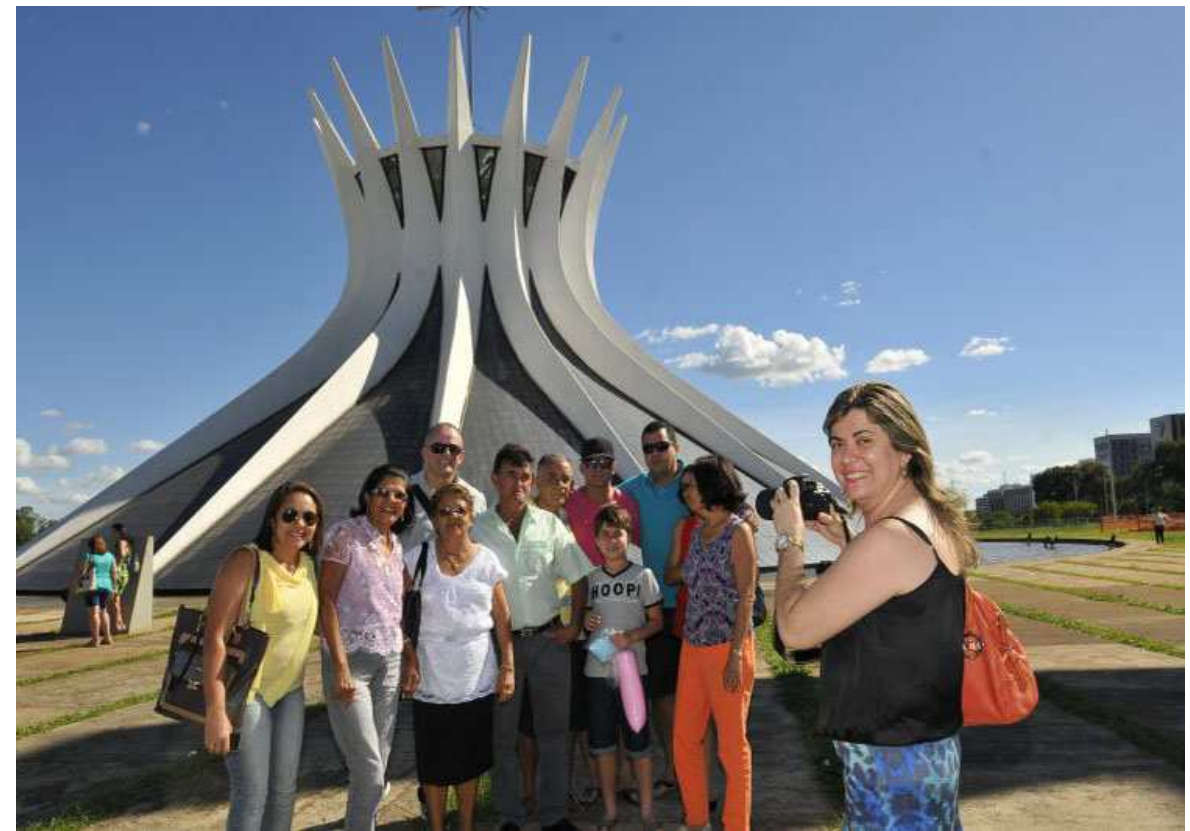

Fonte: Bento Vianna Turista na cidade de Brasília ${ }^{28}$ (2014)

28 http://www.correiobraziliense.com.br/app/noticia/cidades/2014/12/29/interna_cidadesdf,463797/festada-virada-na-esplanada-nao-empolga-turistas-que-visitam-o-df.shtml 


\section{A Escala Residencial}

Figura 31: Superquadra de Brasília (106 sul)

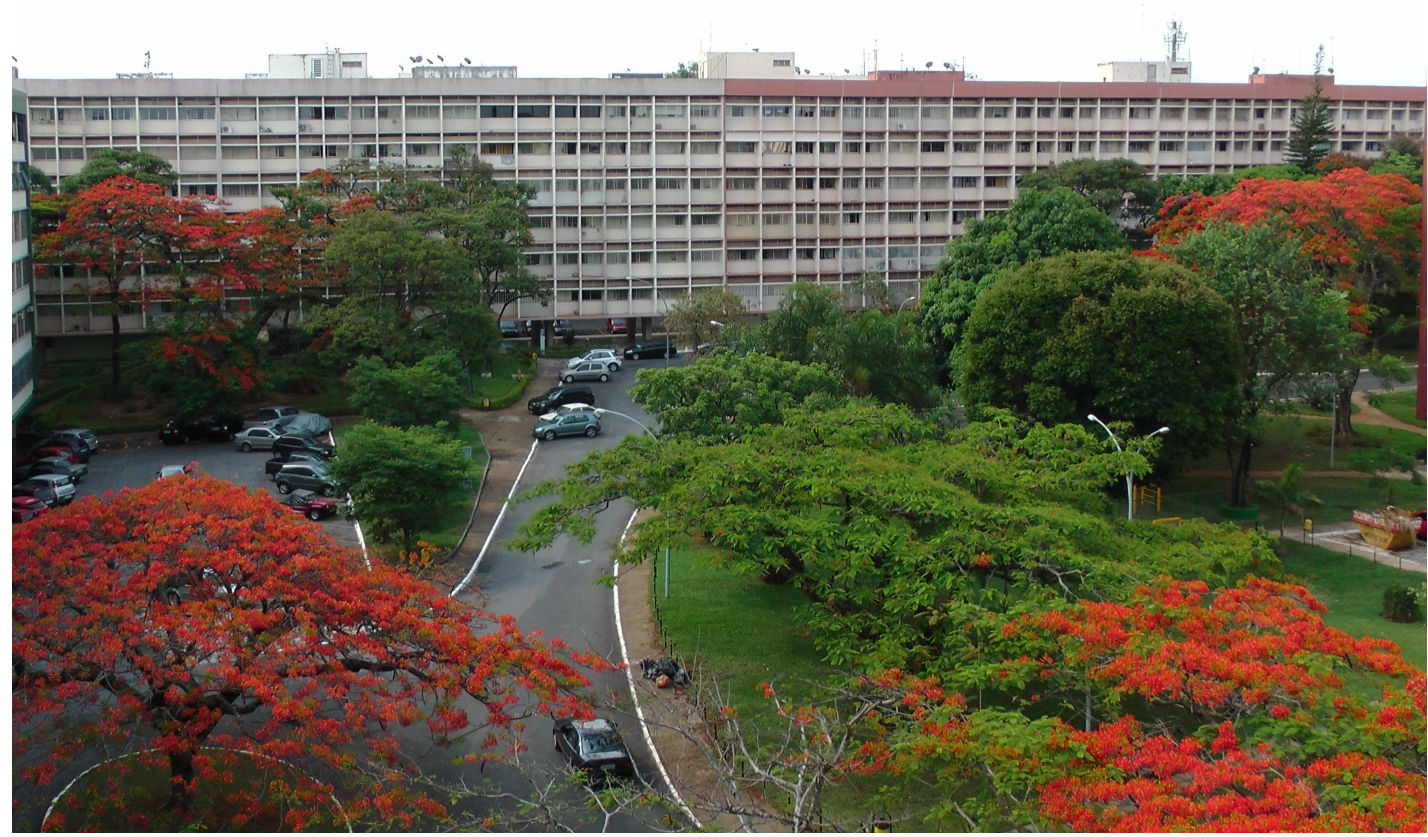

Fonte: Tatiana Terra (2012)

A escala residencial é apresentada na concepção da cidade pela proposta inovadora da Superquadra, cuja tranquilidade urbana é "assegurada pelo gabarito uniforme de seis pavimentos, o chão livre e accessível a todos através do uso generalizado dos pilotis e o franco predomínio do verde" (COSTA, 1987), incorpora a escala bucólica por suas "extensas áreas livres, a serem densamente arborizadas ou guardando a cobertura vegetal nativa, diretamente contígua a áreas edificadas" (COSTA, 1987).

Estruturalmente, uma superquadra é um conjunto de edifícios residenciais sobre pilotis (que têm em Brasília, pela primeira vez, presença urbana contínua) ligados entre si pelo fato de terem acesso comum e de ocuparem uma área delimitada - no caso, um quadrado de 280x280 metros, a ser cercado pelos quatro lados com renques de árvores de copa densa -, e com população de 2500 a 3000 pessoas. O chão é público - os moradores pertencem à quadra, mas a quadra não lhes pertence - e é esta a grande diferença entre superquadra e condomínio. Não há cercas, nem guardas, e no entanto a liberdade de ir e vir não constrange nem inibe o morador de usufruir de seu território, e a visibilidade contínua assegurada pelos pilotis contribui para a segurança. (...) $\mathrm{O}$ fato é que a população assimilou a superquadra com facilidade; os pilotis livres, a presença dos porteiros, o espaço para correr e brincar, os gramados generosos, permitem que as crianças se soltem desde muito pequenas. E as crianças convivem de igual a igual com outras crianças desconhecidas, vindas dos mais 
diversos recantos do país - não havia lugar para preconceitos que normalmente existem na classe média nas cidades de origem: as pessoas não tinham sobrenome. Na quadra, todos eram pessoas igualmente novas, num ambiente novo. E foi daí que surgiu uma geração nova, uma maneira de viver nova, que começa gerar uma nova cultura. A superquadra é a verdadeira raiz de Brasília, que fez a árvore crescer e dar frutos (COSTA apud TAMANINI, 2003).

É a Escala Residencial que apresenta áreas abertas e propícias para a caminhada, onde não há muros, nem restrições. Os prédios são em sua maioria dispostos acima do nível do chão, sobre pilotis - pilares de sustentação - que proporcionam o livre acesso a todos que queiram passar.

Historicamente os muros nas construções das cidades, separam o ambiente aberto natural do fechado da urbe. Em Brasília os "muros" da área residencial são árvores de grande porte que protegem as edificações dos ventos e sons dos carros, promovem as sombras e equilibram a temperatura. São muros que não restringem o acesso do cidadão e caracterizam a continuidade da área habitada.

Em 1960, mesmo ano de inauguração da cidade de Brasília, Mumford ${ }^{29}$ discorre em um artigo publicado na revista Landscape and Townscape sobre os espaços livre e verdes em uma cidade. Comenta que no séc. XIX, os espaços livres eram relacionados com a higiene e saúde pública, eram os "espaços verdes sanitários", citando Camillo Sitte. Eram espaços de contraponto ao caos no trânsito e a desordem da cidade, voltados ao lazer, necessários e entendidos como locais de refúgio, que funcionavam como papel social, próximos ao sonho das cidades-jardins ${ }^{30}$ de Ebenezer Howard, mas que não deveriam estar tão longe da urbe - "poucos são os projetos ou realizações do urbanismo da última geração que levaram em conta esta situação"- e a cada dia o campo estava se tornando mais distante da cidade, quando não se tornavam zonas de lazer que sofriam uma invasão turística que eliminava o valor recreativo, produzindo congestionamento e aniquilando os "recursos estéticos da paisagem". Propõe para a construção das novas cidades "uma mudança qualitativa" para permissão

\footnotetext{
${ }^{29}$ Landscape and Townscape, artigo publicado na revista Landscape em 1960 e reeditado no conjunto de trabalhos publicados sob o título The Highway and city, Londres, Secker \& Warburg, 1964. In O Urbanismo, de Françoise Choay, 2005.

${ }^{30}$ Modelo de cidades criado por Ebenezer Howard no final do século XIX que propunha a interação entre cidade-campo, maior liberdade aos moradores e atenção à vida comunitária.
} 
da verdadeira prática da função social dos espaços livres”. Foi o que considerou Lucio Costa ao elaborar as Superquadras, em total comunhão ao pensamento de Mumford.

Figura 32: Disposição das quadras residenciais e o cinturão verde que permeia toda a Escala Residencial.

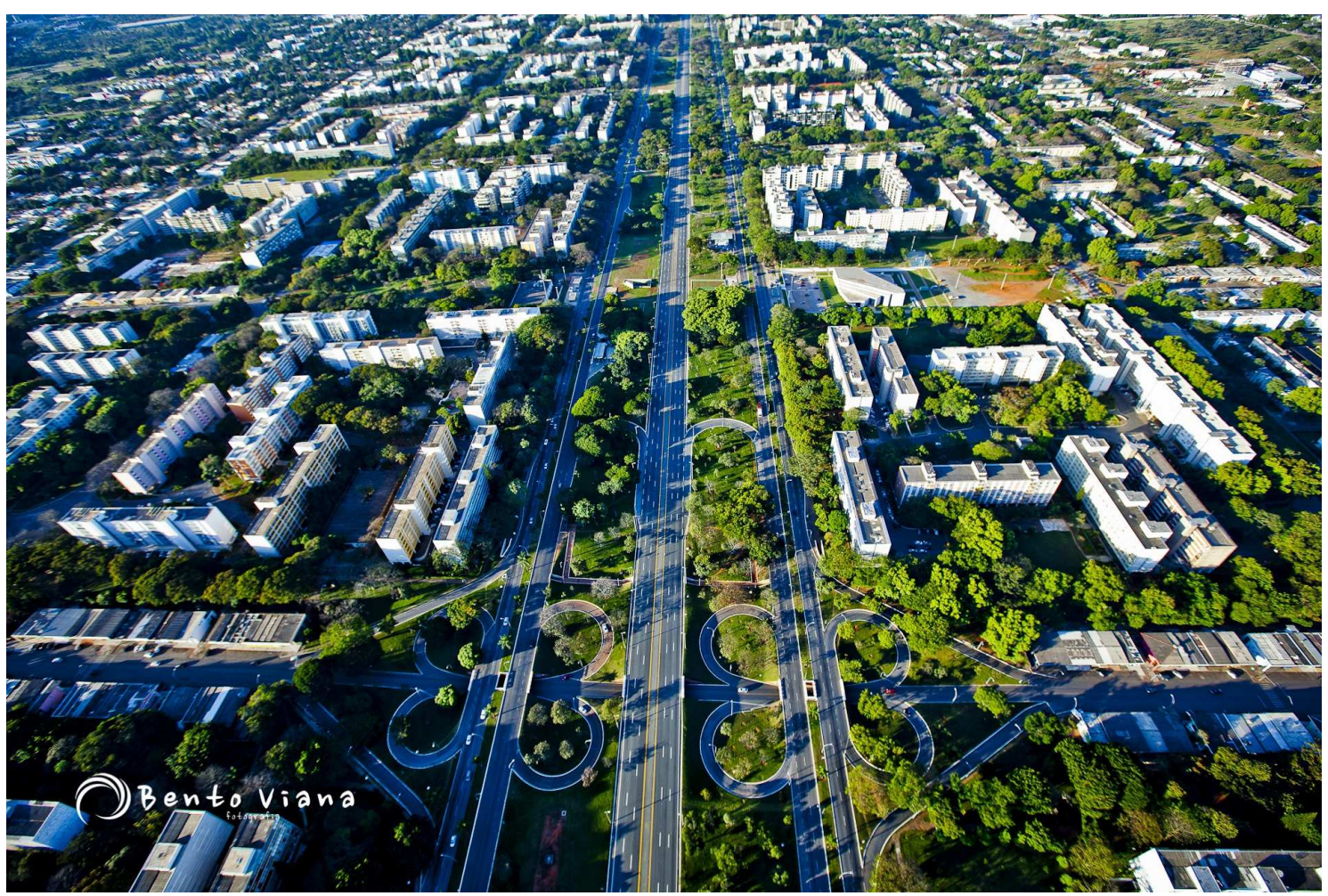

Fonte: Bento Vianna (2014)

As Superquadras residenciais, intercaladas pelas Entrequadras (comércio local, recreio, equipamentos de uso comum) se sucedem, regular e linearmente dispostas ao logo dos $6 \mathrm{~km}$ de cada ramo do eixo arqueado - Eixo Rodoviário-Residencial. A escala definida por esta sequencia entrosa-se com a escala monumental não apenas pelo gabarito das edificações como pela definição geométrica do território de cada quadra através da arborização densa da faixa verde que a delimita e lhe confere cunho de 'pátio interno' urbano (COSTA, 1987).

Numa Superquadra, os espaços livres se caracterizam pelo cinturão verde, passeios sombreados e o acesso irrestrito por pilotis. Em todas elas (Sul e Norte) "a taxa de ocupação para a totalidade das unidades de habitação conjunta é de $15 \%$ da área do terreno compreendido pelo perímetro externo da faixa verde" ${ }^{\natural 1}$. Compreendem as Unidades de Vizinhança que são os conjuntos de quatro quadras residenciais, que se repetem ao longo das Asas, sem acesso ao trânsito de automóveis, e se destinam à promoção social dos moradores, ao encontro comunitário, para a prática de esporte e

\footnotetext{
${ }^{31}$ Portaria n ${ }^{\text {o }}$ 314, de 08 de outubro de 1992.In http://portal.iphan.gov.br/portal/baixaFcdAnexo.do?id=414
} 
cultura, mas que, em oposição à ideia do espaço de lazer afastado da cidade, localizamse como um parque paisagístico em meio a urbe. Em diálogo ao pensamento de Mumford (1960), seria a área de - integração dos lazeres, pista para pedestres, áreas de piqueniques, acessível aos habitantes e turistas, com a matriz verde que integra campo e cidade.

Figura 33: Quadra residencial com Unidade de Vizinhança

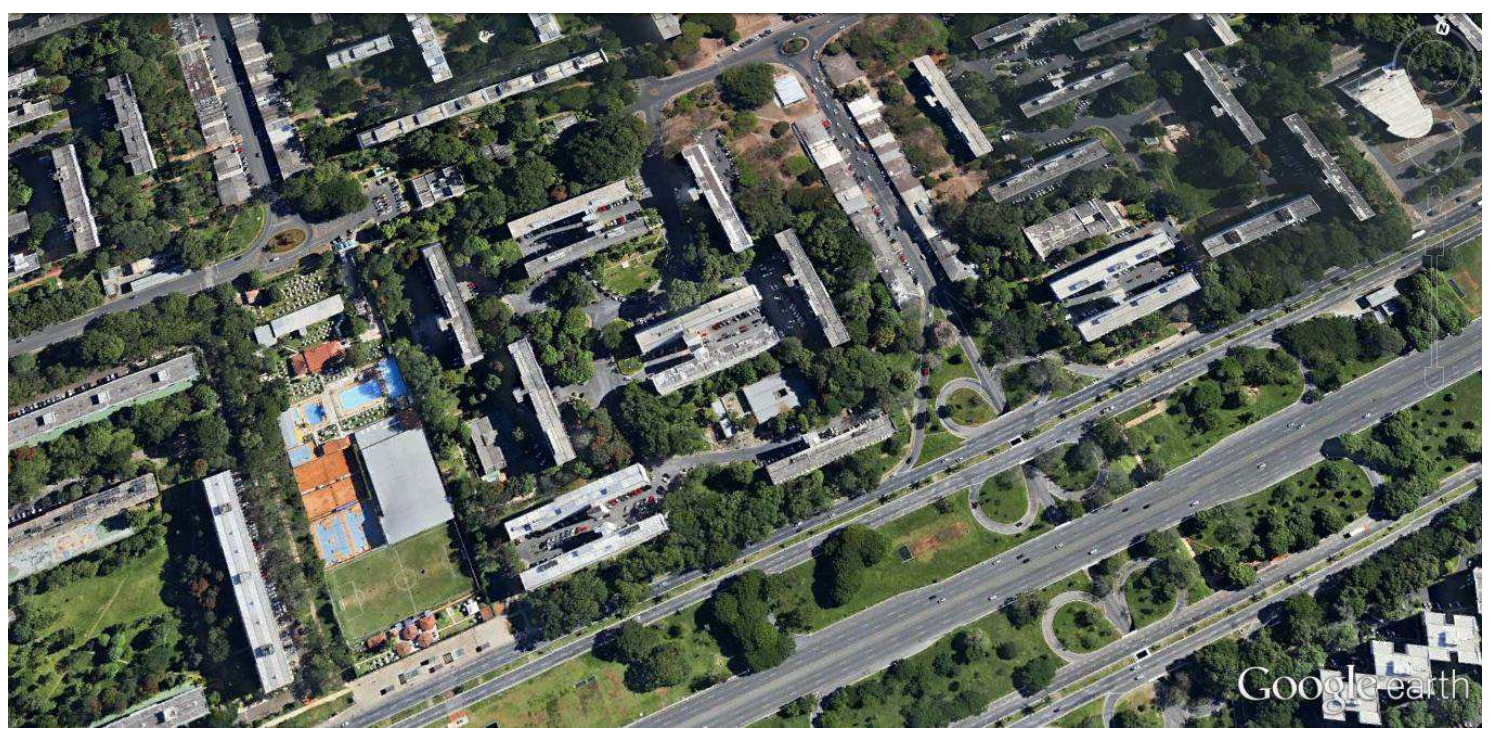

Figura 34: Apresentação de música na Banca de Revistas (SQS 208 sul)

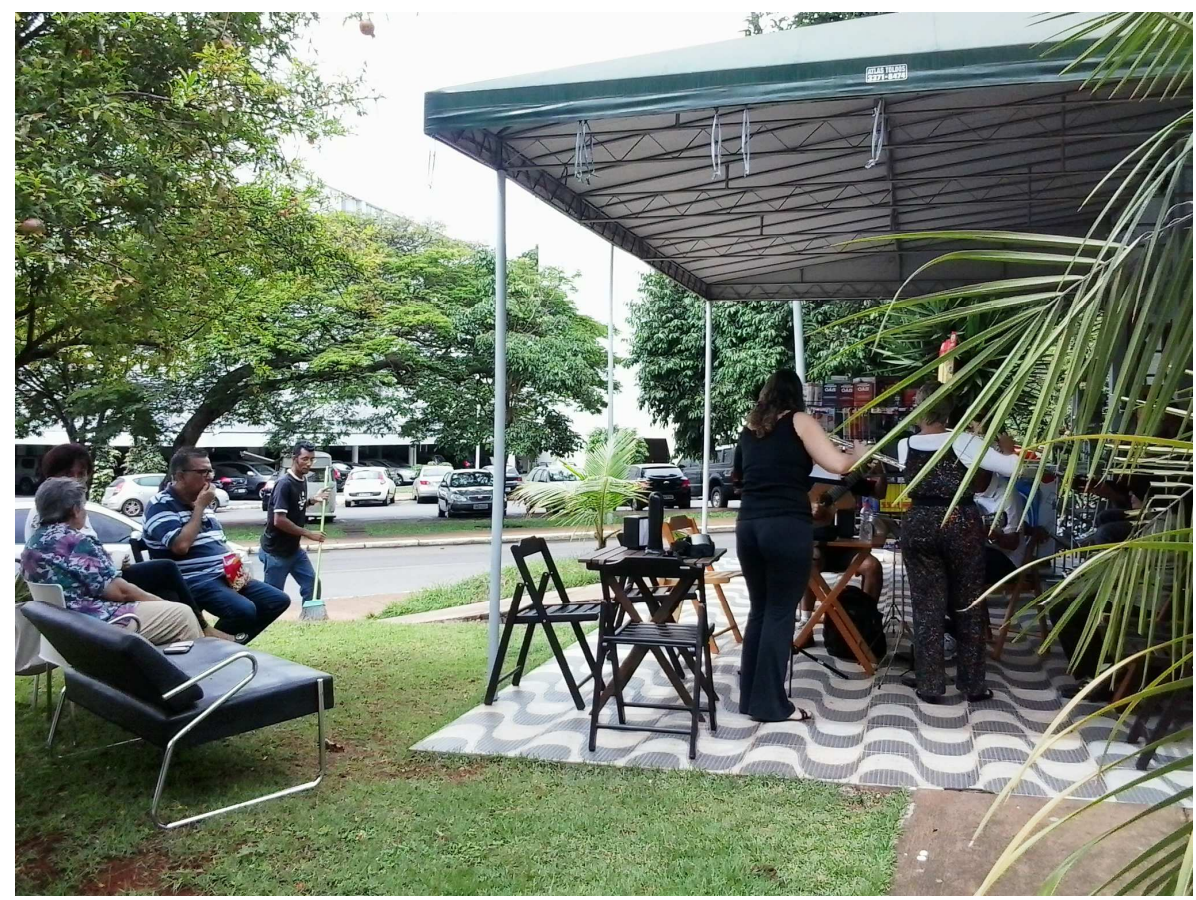

Fonte: Tatiana Terra (2013) 
"Os termos quadra e superquadra passaram a fazer parte do vocabulário da arquitetura mundial exatamente com essa grafia, sem tradução para nenhum outro idioma”. O que vale também para as quatro escalas do Plano Piloto ${ }^{32}$.

As quadras residenciais idealizadas para os habitantes e moradores da cidade de Brasília, por seu criador, são espaços abertos, onde a circulação é plena e os espaços, em sua maioria, são de livre acesso a todos, diferentemente da tendência mundial das cidades contemporâneas na construção de espaços residenciais cercados, que intensificam o paradigma das cidades fragmentadas e excludentes, como exemplo os condomínios, que

em nome da segurança, se fecham ao espaço público e resolvem suas necessidades de integração social intramuros. O ponto de contato entre o condomínio e a cidade é o portão, convenientemente vigiado, de entrada e saída de carros, muitos deles de vidros escuros que tornam invisíveis seus moradores aos cidadãos da rua (GHIONE, 2012).

Figura 35: Representação de Lucio Costa para as quadras residenciais de Brasília

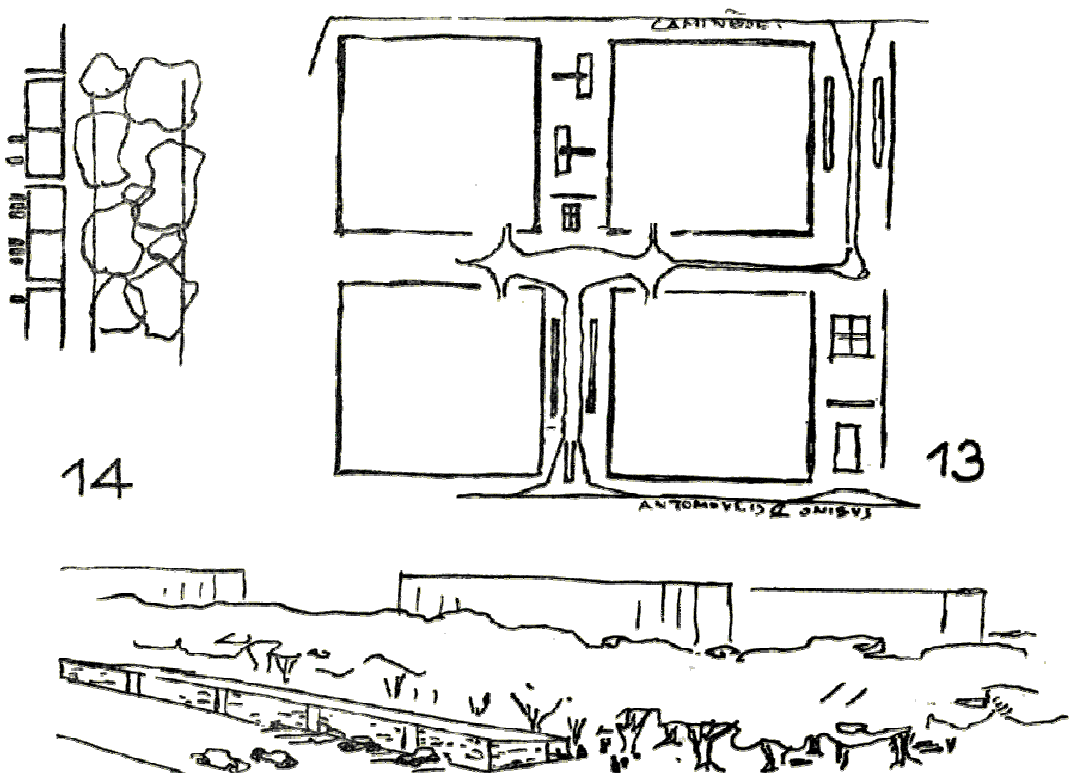

Fonte: Projeto para o Plano Piloto (Lucio Costa)

32 A designação e articulação das quatro escalas que determinam o plano de Brasília não têm nenhum equivalente. Aqui, os termos resistem à tradução: bucólica, residencial, e monumental têm conotação sui generis ( TAMANINI, 2003). De fato, encontramos artigos internacionais como exemplo: Introduction: The Superquadra and the importance of Leisure, em EL-DAHDAH, Farés (editor convidado). CASE: Lúcio Costa Brasilia's Superquadra. Munique, Berlim, Londres, Nova York: The Harvard. Design School- Prestel, 2005. 


\section{A Escala Bucólica}

Figura 36: Espaço comercial de uma Entrequadra (115 sul)

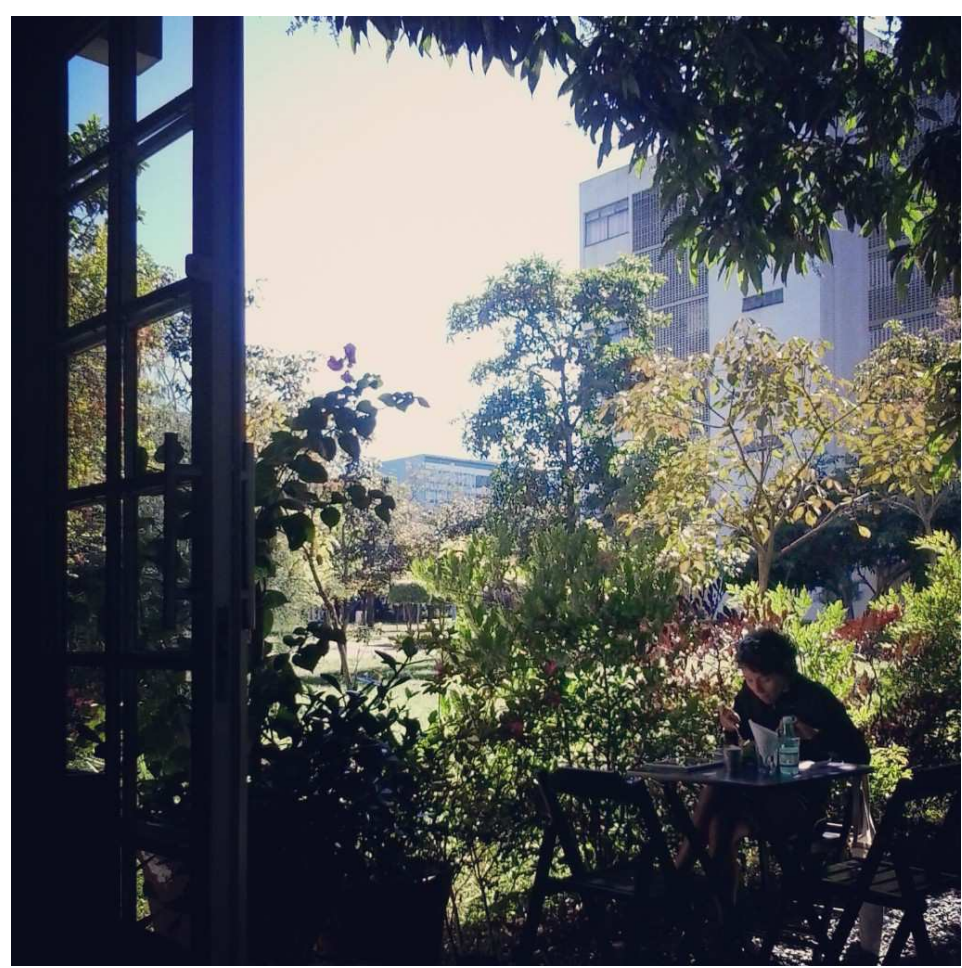

Fonte: Tatiana Terra (2014)

A Escala Bucólica permeia a Escala Residencial. É a escala de lazer, que compreende as extensas áreas livres, com gramados, passeios, bosques e jardins que envolvem toda cidade e muitas vezes são consideradas áreas sem destinação, mas vale reforçar que as áreas verdes livres são elementos do projeto urbanístico que trazem equilíbrio entre as áreas edificadas. E é justamente a presença da escala bucólica que dá o ritmo e a harmonia do espaço urbano ${ }^{33}$, pois unifica os espaços livres e ocupados. Afinal no pensamento de Lucio Costa "urbanizar consiste em levar um pouco da cidade para o campo e trazer um pouco do campo para dentro da cidade" (COSTA, 2001). Uma inovação que deveria trazer para as cidades o pensamento de Mumford (1960): a introdução em “bairros 'superconstruídos' da luz do sol, do ar puro, dos jardins, das praças públicas e do passeio para pedestres (...) sem deixar de cumprir funções estritamente urbanas", soluções que na concepção do arquiteto, "fariam da cidade um lugar tão agradável quanto os antigos subúrbios, onde se poderia viver e criar os filhos"(MUMFORD,1960 apud CHOAY,2005). Sendo assim, conceber para a cidade a

\footnotetext{
${ }^{33}$ Ibdem
} 
possibilidade de morar e se movimentar tendo em vista uma interação ao bucólico e a contemplação de $180^{\circ}$ de céu, é pensar naquele que em seu espaço habita.

Figura 37: Escala bucólica que permeia a Superquadra

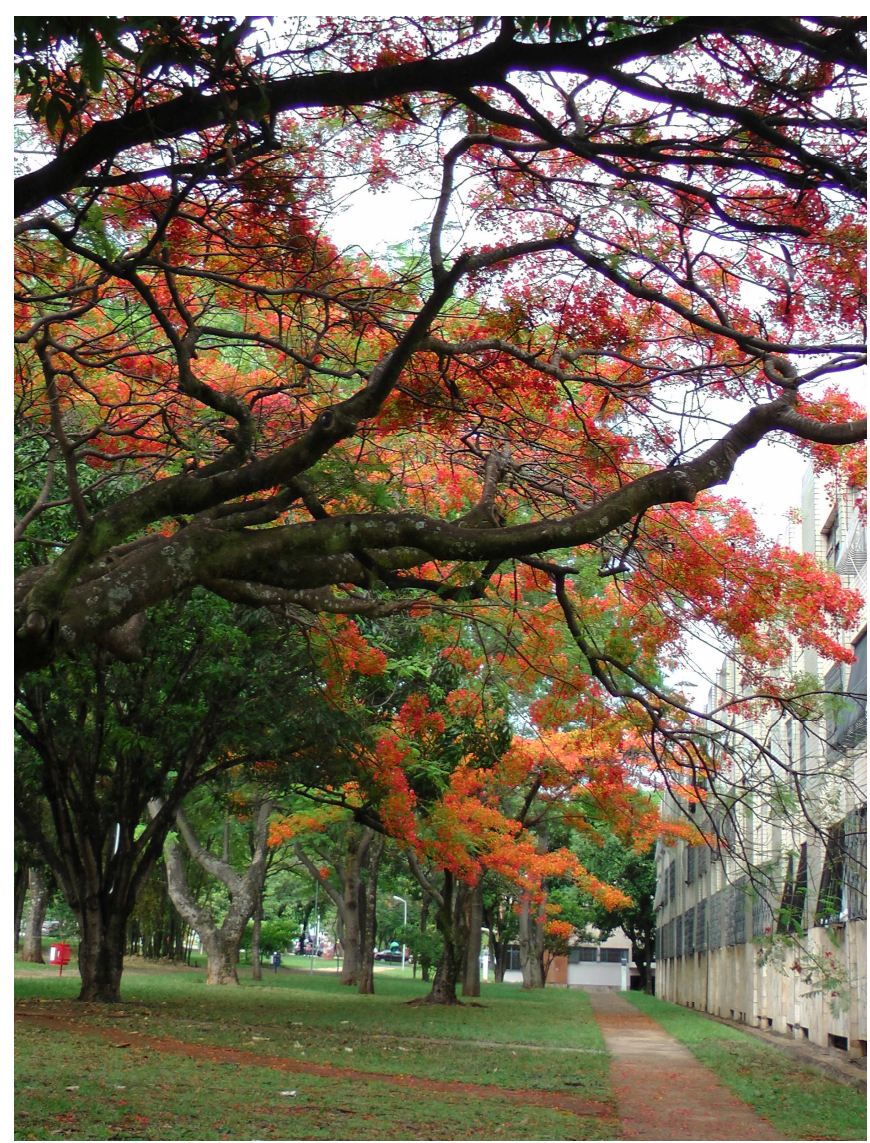

Fonte: Tatiana Terra (2012)

É propor um "organismo capaz de preencher satisfatoriamente as funções vitais próprias de uma cidade moderna qualquer, não apenas como urbs, mas como civitas" ${ }^{\text {34 }}$. Idealizada para além da capital administrativa do Brasil, como espaço cômodo e acolhedor, onde se valoriza o ser humano, privilegia a conexão do espaço com o corpo e proporciona a vivência de práticas mais humanas por visitantes e moradores, afinal “...nós não habitamos somente nosso apartamento, mas o pátio, a rua e a cidade até o horizonte" ${ }^{, 35}$, um entendimento intrínseco do traço de Lucio Costa.

\footnotetext{
${ }^{34}$ Projeto de Lucio Costa disponível no site do IPHAN http://portal.iphan.gov.br/portal/baixaFcdAnexo.do?id=280

${ }_{35}$ Mongin apud Henri Gaudin, in Chris Yonés (OrGg), Arte t philosophie, ville et architeture, Paris: La Découverte, 2003, p.276
} 
Figura 38: Escala bucólica- Presença do horizonte

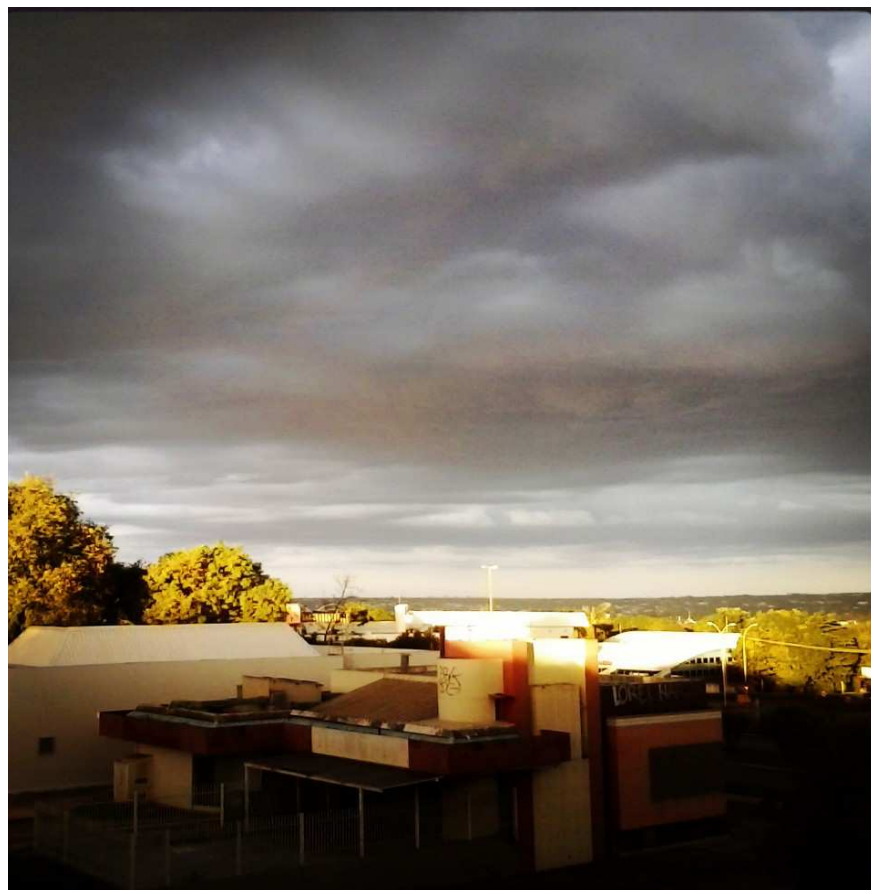

Fonte: Tatiana Terra (2012)

De acordo com a Portaria n 314 do IPHAN, de outubro de 1992, Artigos $4^{\circ}$ e $8^{\circ}$

A escala residencial, proporciona uma nova maneira de viver, própria de Brasília (...) Cada Superquadra (...) será cercada, em todo seu perímetro, por faixa verde de vinte metros de largura com densa arborização (...) Confere a Brasília o caráter de cidade parque, configurada em todas as áreas livres, contíguas a terrenos edificados (...) destinadas à preservação paisagísticas e ao lazer (...) Prevalece a cobertura vegetal do cerrado nativo, esta será preservada e as demais serão arborizadas na forma de bosque... (IPHAN,2007)

Figura 39: Entrequadra em dia de chuva

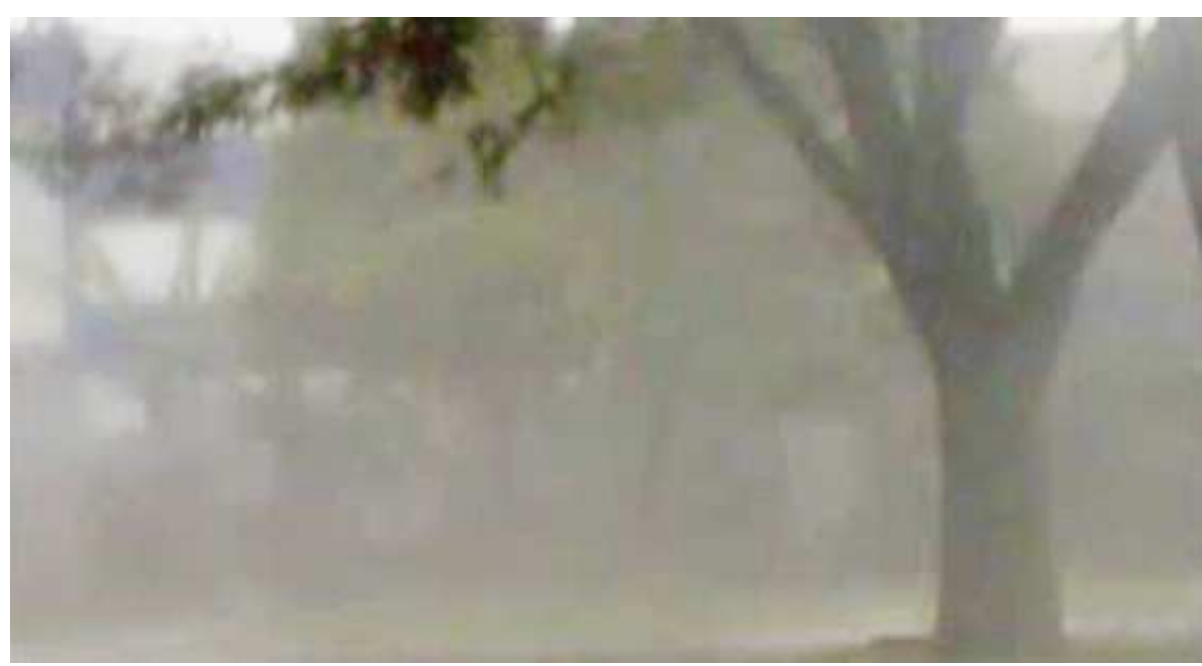

Fonte: Tatiana Terra (2009) 
No entanto, ainda que fortemente presente nas Entrequadras Residenciais, a Escala Bucólica está também na orla do lago, com pretensão de acesso livre a todos (excluído as áreas de clubes) e no "imenso céu do planalto, como parte integrante e omnipresente da própria concepção urbana - os 'vazios' são por ele preenchidos; a cidade é deliberadamente aberta aos 360 graus do horizonte que a circunda" (COSTA, 1987).

Figura 40: Céu de Brasília

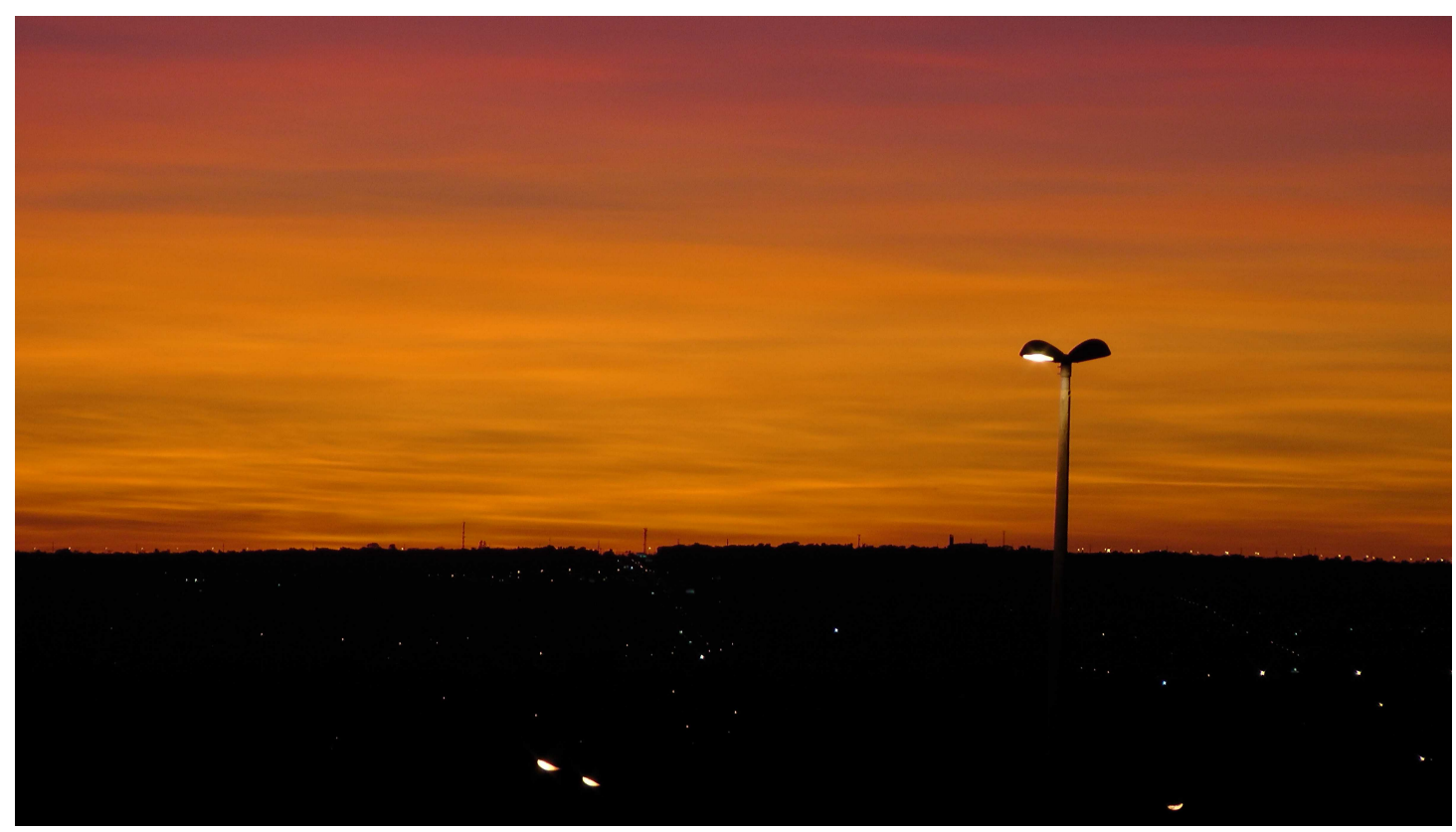

Fonte: Tatiana Terra (2014)

Os aspectos destas duas Escalas: Residencial e Bucólica fortalece o conceito do uso do espaço público, que em Brasília pode ser aproveitado por seus moradores e visitantes. Exemplos de como as pessoas utilizam o espaço da cidade conforme o desenho urbano, pelo mesmo aspecto que o espaço urbano movimenta pensamento e as ações é o que veremos a seguir. O próximo capítulo representa a apropriação do espaço cidade e o redesenhar do seu traçado urbano, como confirmação do conceito, já citado anteriormente, de que a cidade é lugar de múltiplos benefícios "onde a experiência humana se transforma em signos visíveis, símbolos, normas de conduta e sistemas de ordem (...) (em) uma sociedade totalmente diferenciada e consciente de si mesma" (MUMFORD,1945), um lugar de "ebulição permanente" (SANTOS,2014). 


\section{BRASÍLIA REDESENHADA}

Figura 41: Ocupações nos espaços residenciais e bucólicos de Brasília
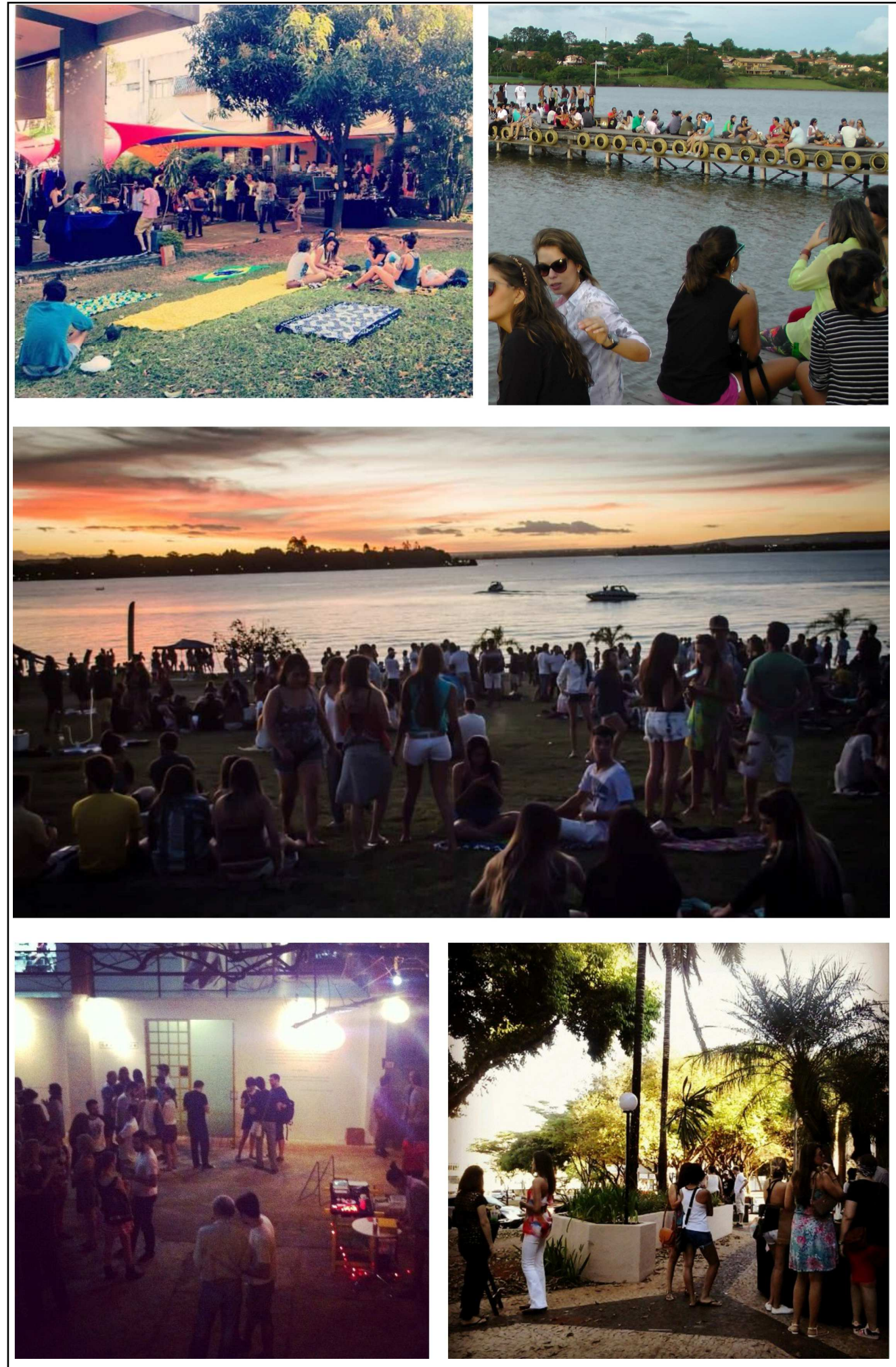

Fontes: Figura 01: Quadrado Brasília (2014); Figura 02: Tatiana Terra (2013); Figura 03:

Camila Sugai (2014); Figura 04: Íris Helena (2014); Figura 05: Tatiana Terra (2014) 
Dizia MUMFORD (1945) que "a cidade é um bem físico da vida coletiva e um símbolo dos movimentos coletivos que aparecem em circunstâncias favoráveis", junto com o idioma, considerava a cidade "a maior obra de arte do homem". Se Ovídio já expressava que "para os romanos o espaço da cidade coincide com o espaço do mundo" (OVÍDIO apud BENEVOLO, 2012), para os gregos a cidade tinha relação direta com a expressão do corpo de quem ela habitava. Os gregos ao exporem seus corpos saudáveis e nus reafirmavam os ideais cívicos, "na Grécia antiga a paixão erótica e o apego à cidade eram designados pelas mesmas palavras" (SENNET, 2008).

Em Brasília, moradores e frequentadores que se expressam e intervêm nos espaços da cidade, tornam-se atores no processo de seu desenvolvimento. Pelas possíveis interações do homem com espaço, exploram a cidade como situação, oportunizando sua recriação nas relações de apropriação, por movimentos coletivos e de solicitação da vivência do corpo no espaço. Movimentos coletivos são identificados desde sua primeira década. As formas de apropriação e movimentos simbólicos que demarcam existência no espaço vivido/vivenciado, como as intervenções urbanas culturais, estiveram presentes em Brasília desde início de sua existência, ainda nos anos 70/80, e alcança hoje uma extensão admirável pela gama de expressões variadas realizadas agora pelos "brasilienses nativos”, os nascidos e criados em seus espaços. Estas expressões merecem ser consideradas pois, estão diretamente associadas ao seu desenho urbano, à concepção do criador no que se refere aos espaços vazios, aos espaços destinados à socialização (como das Entrequadras) e aos espaços bucólicos. Elas estabelecem estreito diálogo à idealização do Plano como (con)vivência urbana.

Foi na década de 70, em plena ditadura militar que moradores e trabalhadores da cidade registraram as primeiras manifestações da "ocupação urbana da "maquete",36 Mesmo diante o processo de modernização interrompido pelo Golpe Militar de 64, em plena ditadura, os espaços vazios da cidade juntavam centenas de pessoas acumuladas na grama, que alimentadas por música e poesia não davam margem à repressão e reivindicavam o direito à cidade: "Estamos sentados na grama. É isso que a gente quer? Ponto", Foi esta "a primeira geração que desceu dos blocos e ocupou a cidade"38.

\footnotetext{
${ }^{36}$ Citação de Neio Lúcio no documentário Sob o "Signo da Poesia" de Neto Borges (2011)

${ }^{37}$ Ibidem

${ }^{38}$ Citação no documentário "Sob o Signo da Poesia" de Neto Borges (2011).
} 
Surge nessa época um grupo denominado Cabeças que movimentava a cidade para se expressar artisticamente, na música, na poesia, no teatro e nas artes visuais, nos espaços abertos da cidade, o mote era sempre o "movimento a céu aberto" Sentiam-se "senhores dos gramados, generais da paz em um tempo de ditadores, cabeças pensantes gerando cabeças pensantes que hoje atuam nos mais diversos campos, inclusive na arte. ${ }^{39}$

Figuras 42,43 e 44: Retratam as ocupações artísticas nos anos 70/80

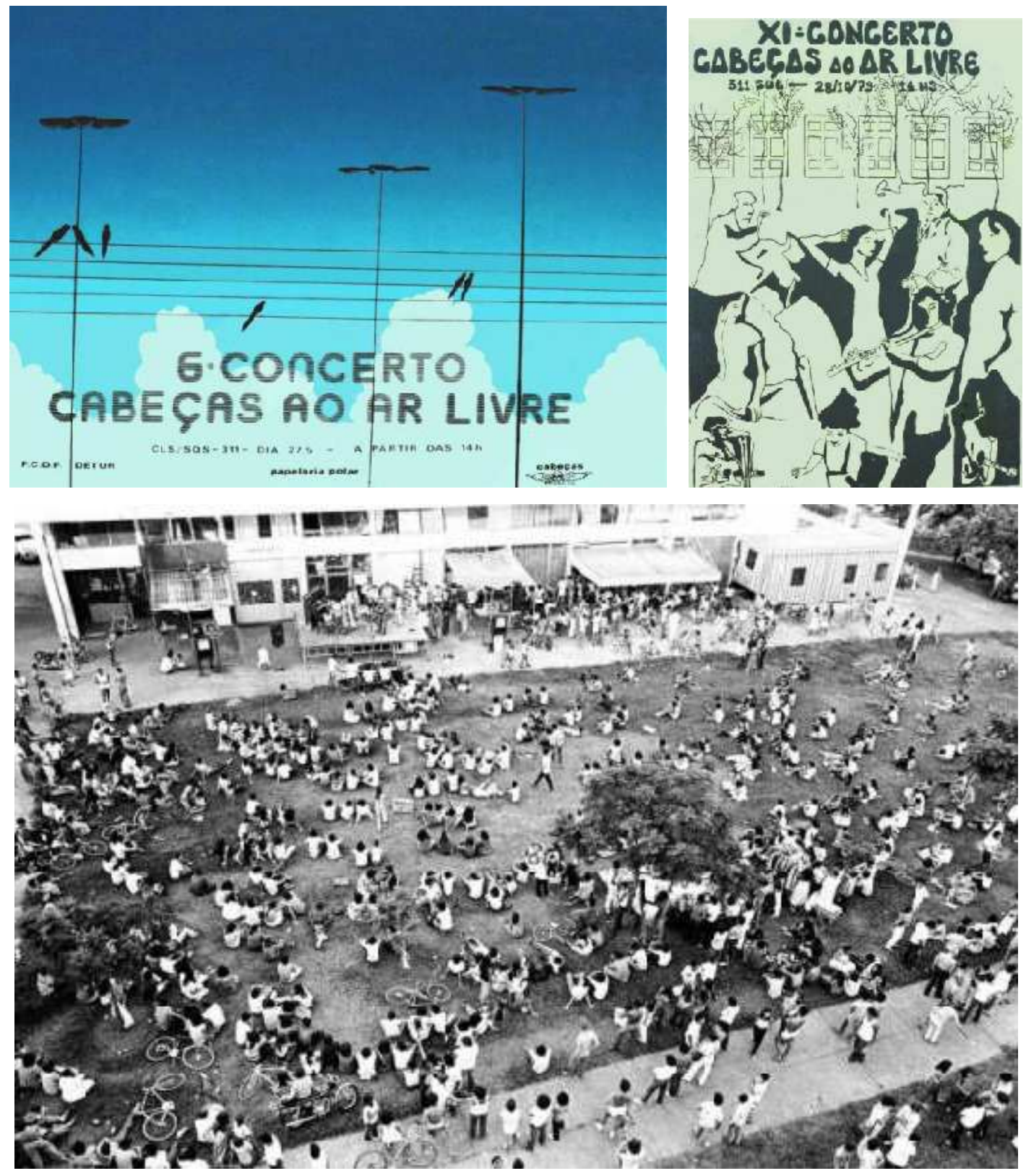

Fonte: cabeças.org (2014)

\footnotetext{
${ }^{39}$ Declaração de José Adalberto Meuren (17/08/2010 13:05), site cabecas.org
} 

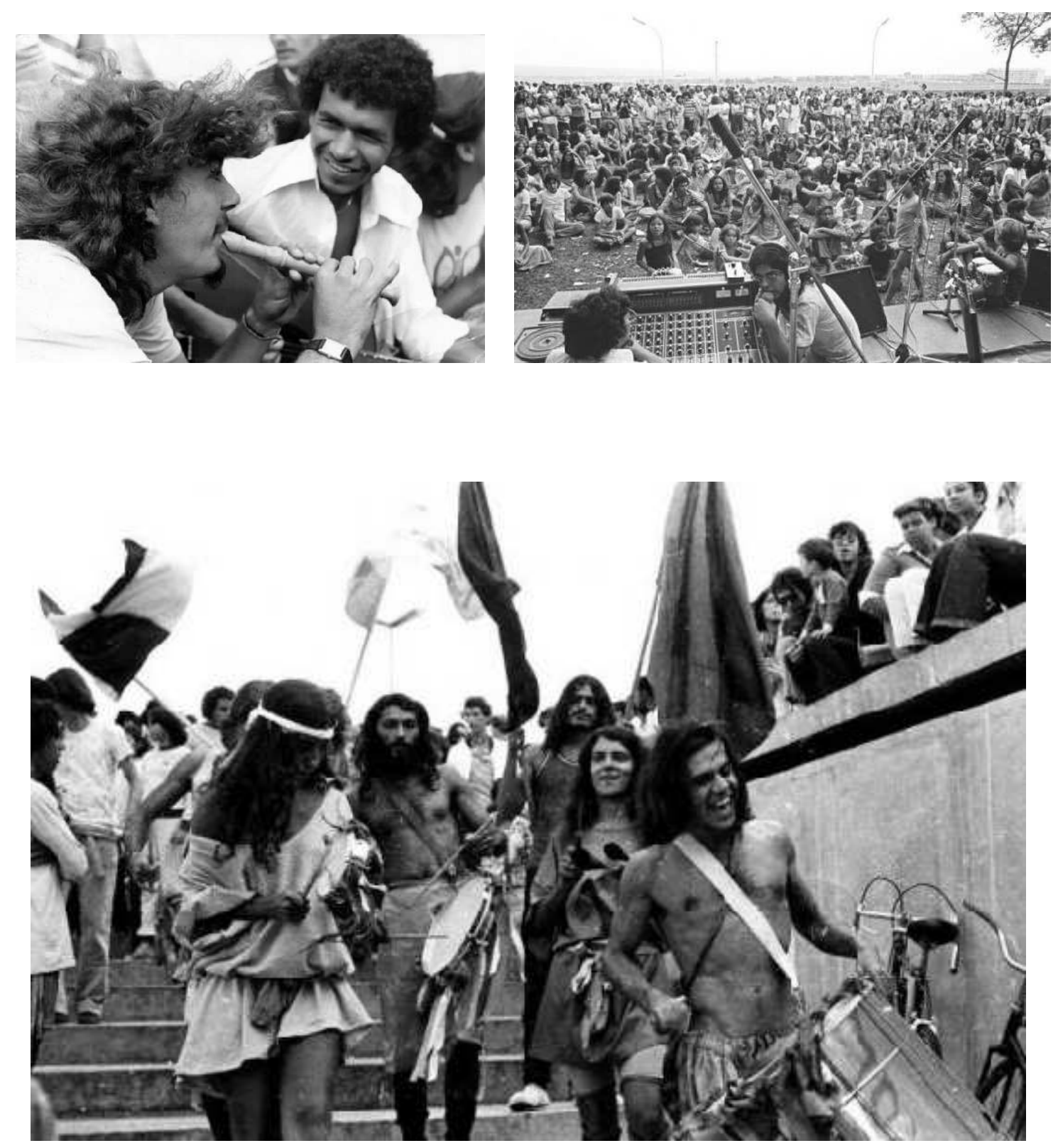

Fonte: cabeças.org (2014)

É fato que em diversas sociedades, movimentos políticos repressivos catalisam manifestações artísticas. E Brasília, no auge dos seus 20 e poucos anos de idade vivenciando plena Ditadura Militar, existia em suas criações poéticas por diversas linguagens artísticas, que incluíam como não poderia deixar de ser, as intervenções urbanas como o grafite, que tinham como suporte, por exemplo, as passagens subterrâneas $^{40}$.

40 Túneis localizados abaixo do trânsito de veículos do Eixo Rodoviário Residencial. Gabriela Bílá comenta que são elas os "becos que Brasília não teve, espaços reclusos em pleno centro urbano que se tornam muito convidativo à arte de rua e eventos alternativos" in O Novo Guia de Brasília. 
Figuras 48,49 e 50: Passagens subterrâneas e intervenções

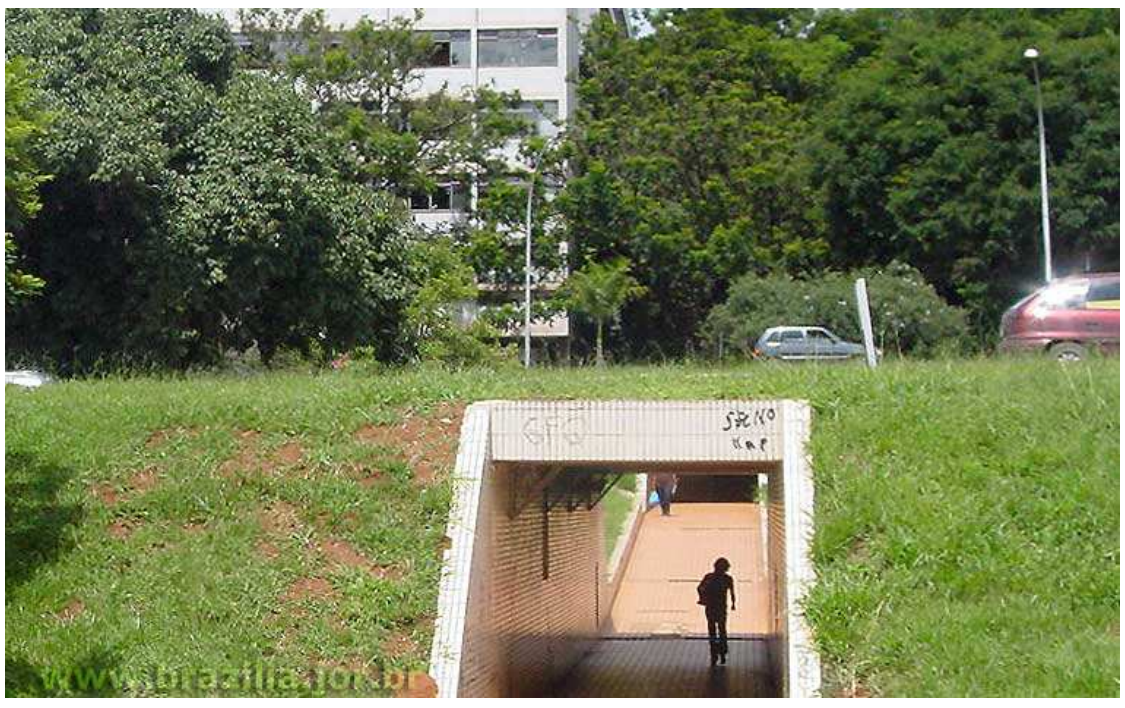

Fonte: Brazilia.jor.br

http://doc.brazilia.jor.br/Vias/Eixo-Rodoviario-Passarelas-inferiores.shtml (2014)

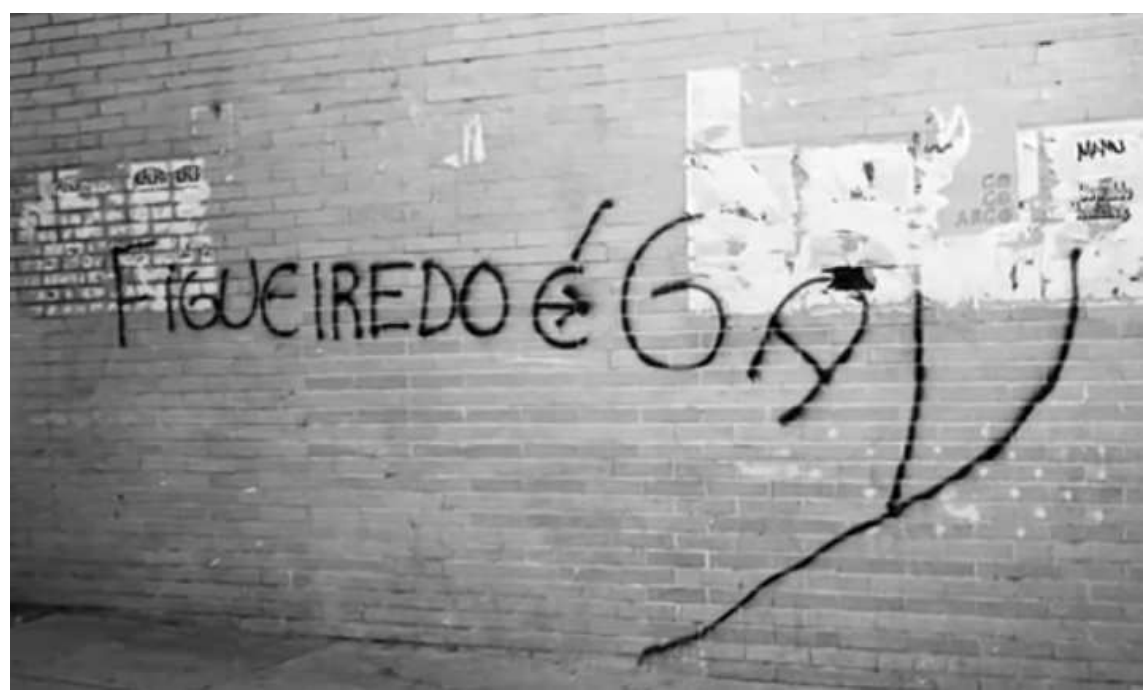

Fonte: cabeças.org (2014)

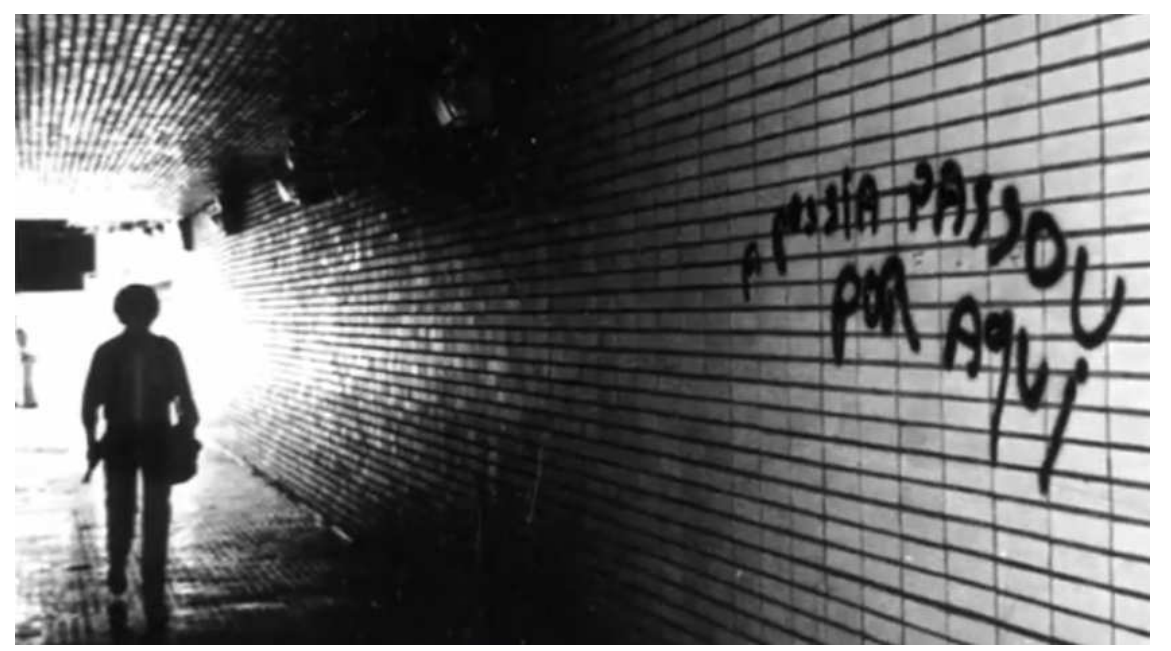

Fonte: cabeças.org (2014) 
O desejo de expressão libertária fomentou a produção de música e poesias que eram distribuídas em livretos nos bares e ruas da cidade, ao mesmo tempo que a cidade e sua paisagem eram cantadas por diferentes grupos que aqui se formavam. Este sentimento de apropriação é relatado no documentário "Sob o sigo da Poesia"(2011), como característica do que há de mais comum nas linguagens artísticas culturais da cidade. Sóter, poeta que na época intervinha com publicações e declamações em bares, teatros, e encontros ao ar livre, considera que vários artistas só aconteceram porque vieram para Brasília devido aos espaços passíveis de ocupação ${ }^{41}$, esta que pode ser entendida não só como física, mas reflexiva também. Nessa época em que Brasília foi considerada a capital brasileira da poesia (anos 70), Nicolas Berh ${ }^{42}$ comenta que "as publicações poéticas eram uma febre”. De fato,

artistas poetas, romancistas e filósofos (...) expressam sua preocupação com um futuro utópico baseado (...) no conhecimento técnico e seus efeitos em relação às diferentes formas de poder administrativo, legal e físico -, que se desdobram em imagens de governos repressivos, sociedades violentas, lugares desagradáveis, perda de referência para a identidade pessoal, indivíduos que cumprem rotinas, mas que se saciam nos prazeres materiais. (LIMEIRA,2006)

Figuras 51 e 52 - Intervenções poéticas em Brasília (anos 70 e 80)
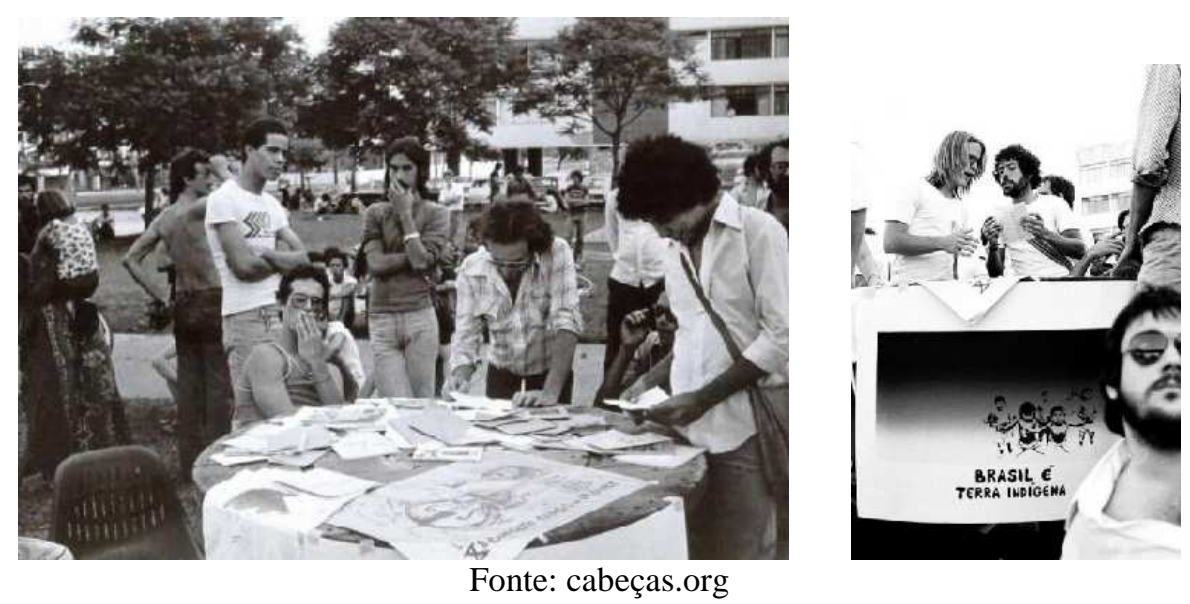

\footnotetext{
${ }^{41}$ Um exemplo desta afirmação é a própria declaração do cantor Ney Matogrosso que entre os anos de 61 e 67, viveu e trabalhou na cidade. Dizia ele que quando ele chegou à cidade de Brasília, ele tinha que se adaptar a tudo, pois os espaços eram inusitados, tinha que atravessar espaços vazios o que era muito estranho para quem era acostumado com uma cidade como o Rio de Janeiro, que Brasília proporcionava não uma solidão, mas uma espécie de enfrentamento de você com você mesmo, esse encontro. Antes de chegar à cidade, fazer arte era um desejo vago, cantar era algo que ele poderia fazer. Comenta que na cidade tudo foi detonado e ele começou a colocar tudo em prática e tendo certeza assim que seria um artista e não poderia fazer outra coisa. In Brasília 50 anos: Arte e Cultura.

${ }^{42}$ Nicolas Behr (Nikolaus von Behr) nasceu em Cuiabá e mora em Brasília desde 1974. Em 1977 lançou seu primeiro livrinho e best seller "Iogurte com Farinha", em mimeógrafo, tendo vendido 8.000 exemplares de mão em mão. Fonte:

http://tertuliaartesanato.com.br/loja/index.php?route=product/category\&path=35_109 (2014)
} 
Hoje, as intervenções artísticas na cidade ainda expressam repressões, de diferentes tipos, políticas ou sociais, mas também trazem o desejo de conscientização do sujeito no espaço da cidade, além do próprio significado dela. Interligam-se e ampliamse as questões de representatividade e existência: O que sou? O que é cidade? Quem sou eu na cidade? Em constante diálogo com demais questões contemporâneas. Quando a cidade para os artistas é suporte da poesia, ela é entendida como o "lugar do poema".

Figuras 53: $\mathrm{O}$ afeto te afeta

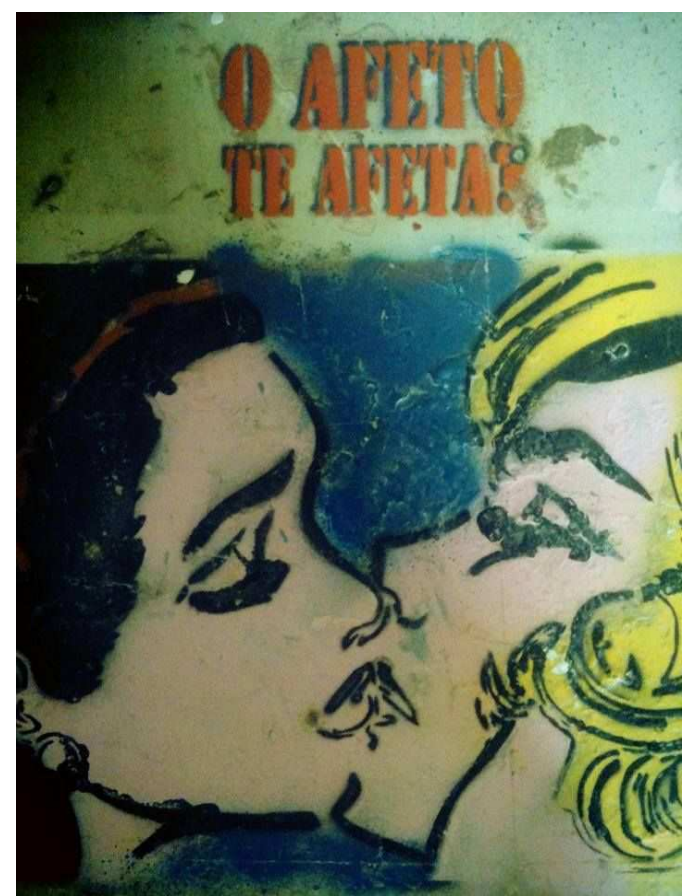

Fonte: Coletivo Transverso (2014)

Figura 54: Quantas cidades tenho em mim?

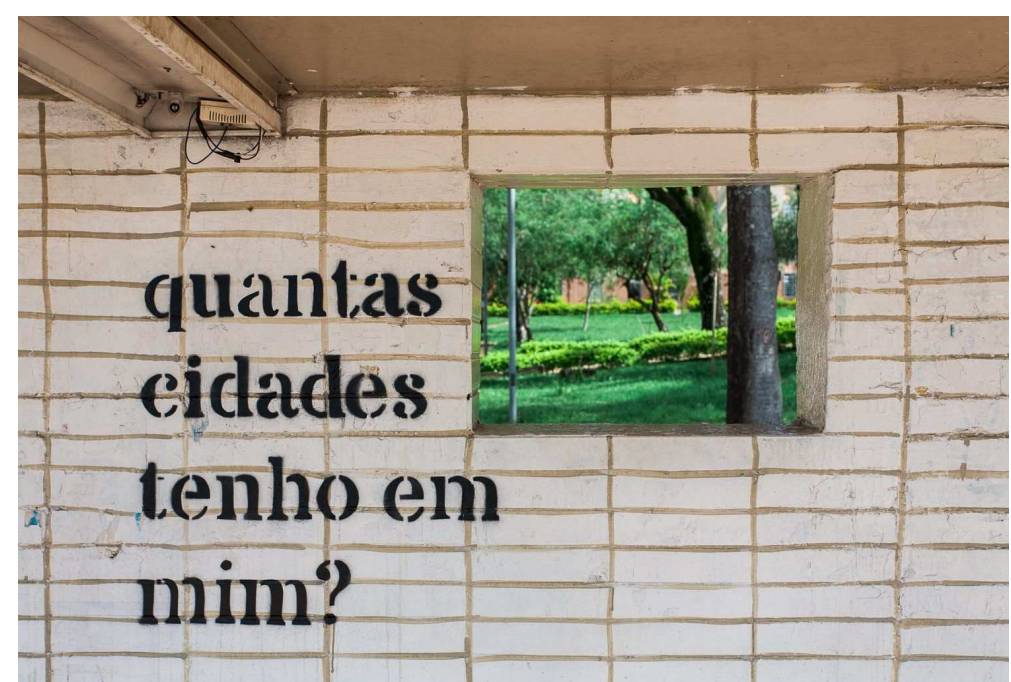

Fonte: Coletivo Transverso (2014) 
Em referência a esta interpretação tem-se o exemplo o grupo artístico "Coletivo Transverso"43, que aproveitam os lugares de passagem nas cidades para exprimirem suas questões. Inspirados pelos "espaços em branco" da cidade moderna, aquela "onde todos os espaços são determinados", determinam o espaço comum urbano como base de maior alcance da sua identidade expressiva.

Figura 55: O que cortam as tesourinhas cortam?

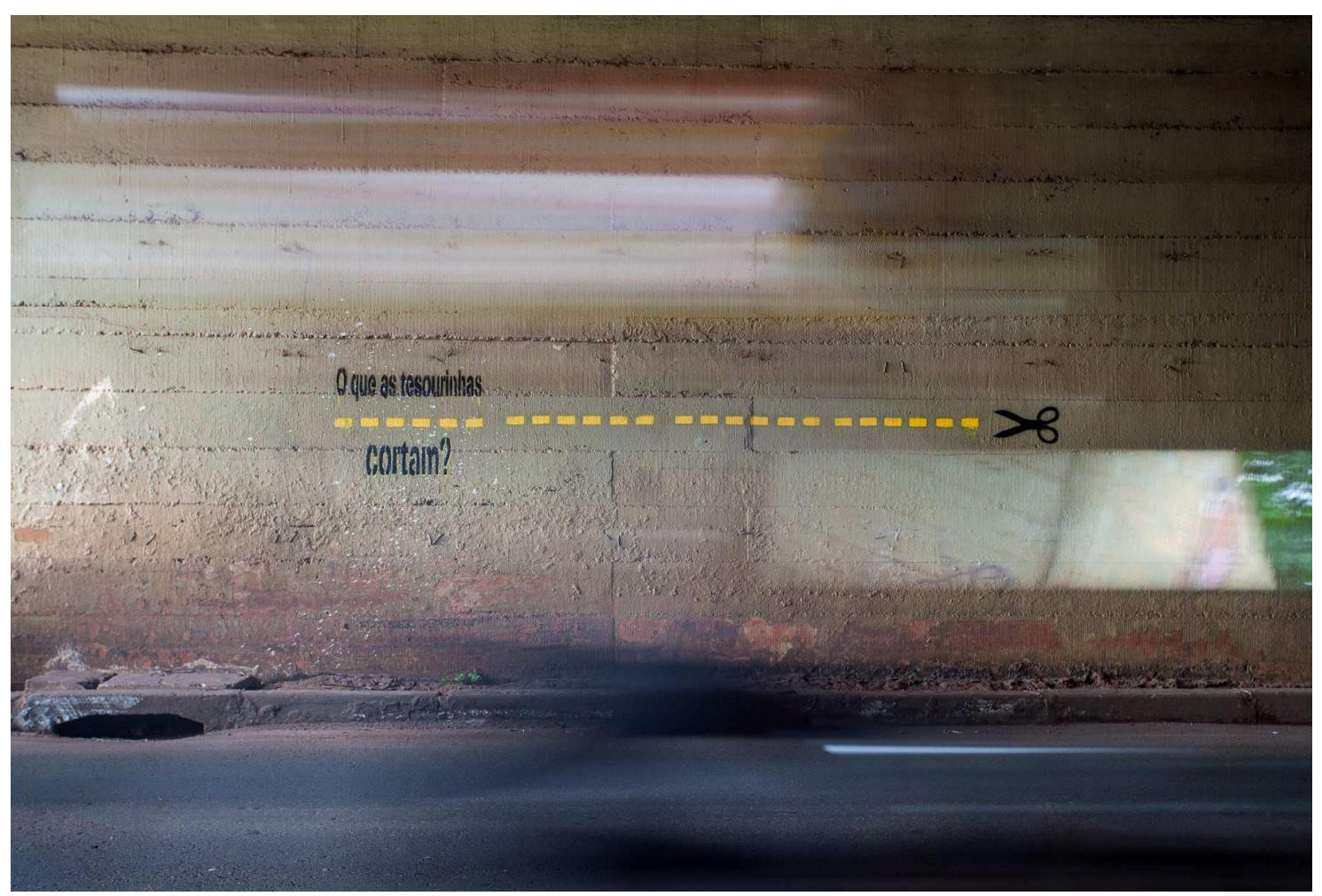

Fonte: Coletivo Transverso (2014)

"O olhar do artista, longe de traduzir apenas imagens fragmentárias, revela as 'qualificações' do espaço urbano. Contrapondo-se em alguns momentos, convergindo em outros com a interpretação de urbanistas e arquitetos" 44

\footnotetext{
${ }^{43}$ O que é o coletivo e declarações expressas em apresentação na universidade de Brasília, CET. $29 / 10 / 2014$

44 Tema de uma exposição intitulada Europa 1870-1993. Visiones Urbanas. La ciudad del artista. La ciudad del arquiteto. Em Barcelona, 1994. In Cidade complexas do Séc.XXI.
} 
Figura 56: Atenção isso pode ser um poema

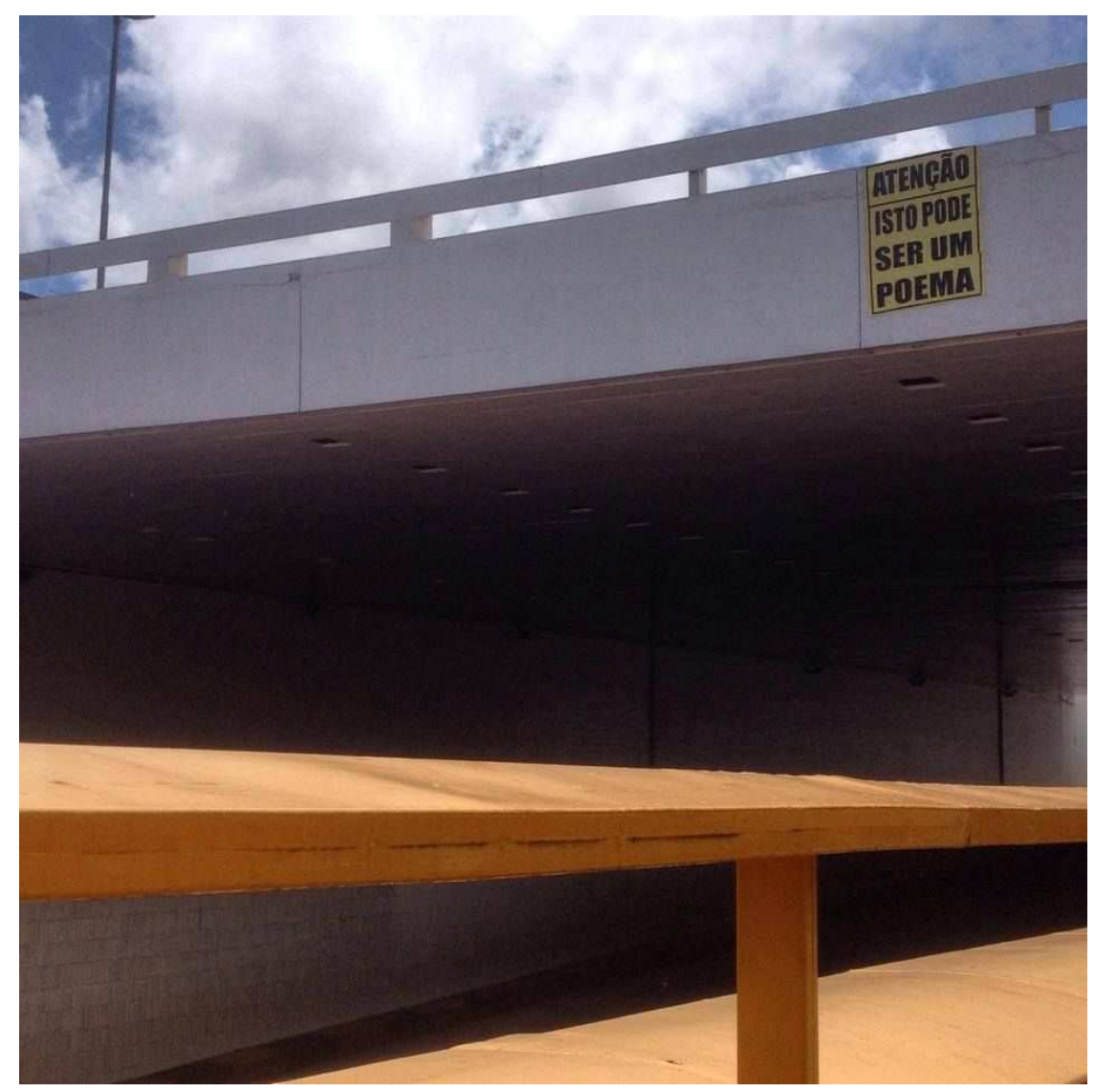

Fonte: Coletivo Transverso (2014)

Figura 57: Teu corpo é meu poema

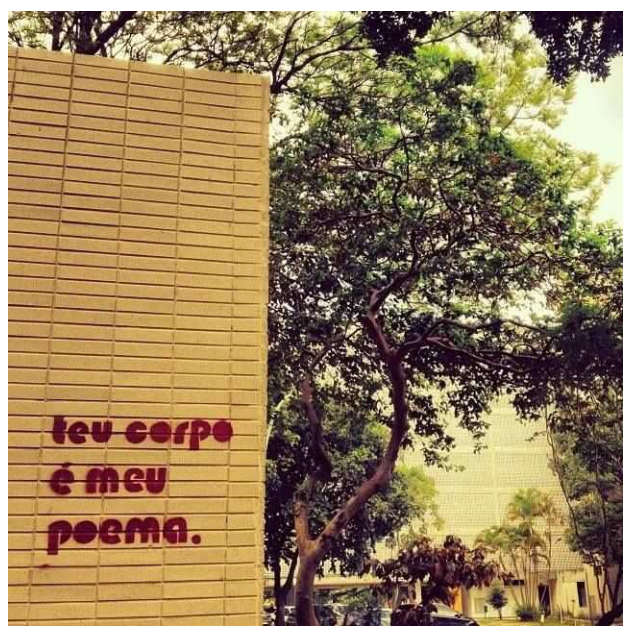

Figura 58: Alimente os pássaros imaginários

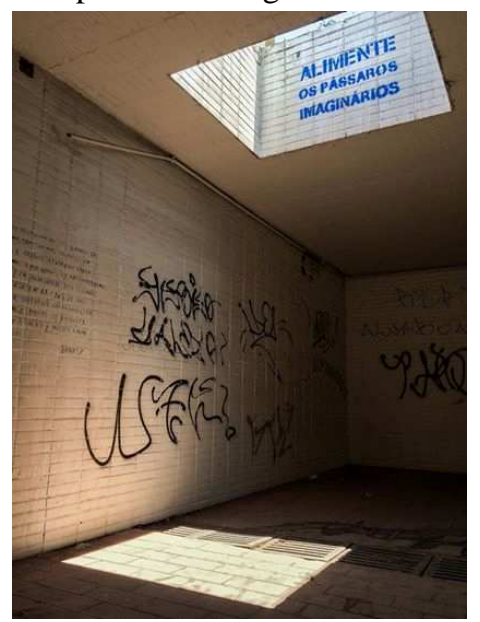

Fonte: Coletivo Transverso (2014)

Inacabadas, como uma própria cidade é, as expressões que habitam a cidade possibilitam recriações, caracterizando-a como palco de comunicação dialética. Fazem elas parte de um processo dinâmico, aberto e transitório. 
Figura 59: A vida é uma questão de .......

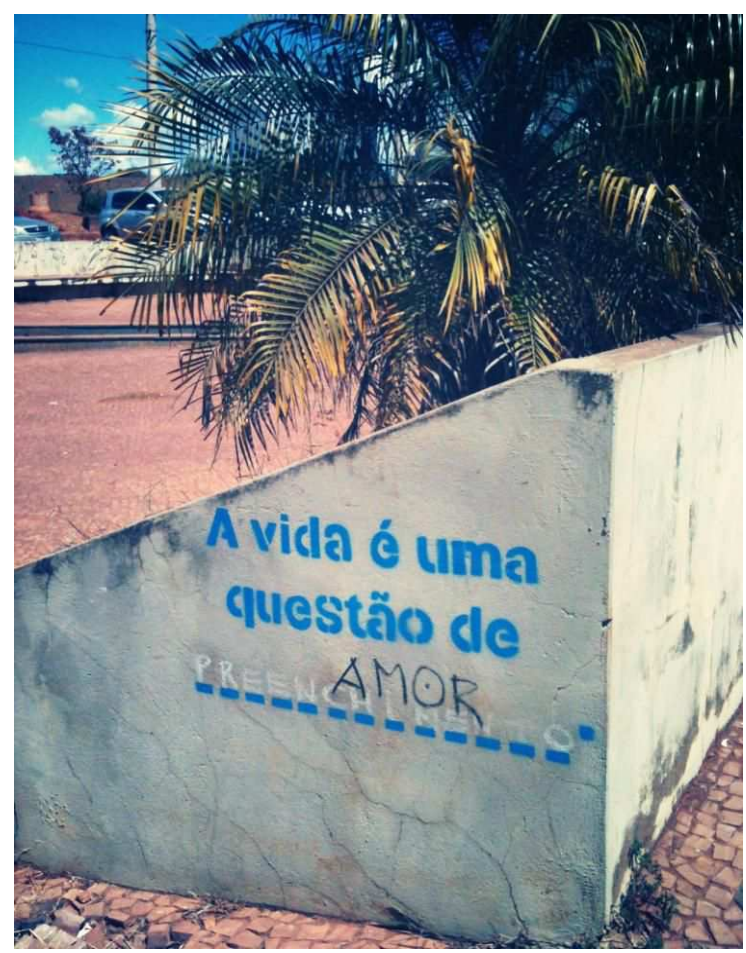

Fonte: Coletivo Transverso

E porque a

cidade não pode ser pensada apenas como projeto, espaço produzido, conjunto finito de bens e funções visíveis, mas como um sistema aberto (...) em seus processos de desenvolvimento, percebida em seus elementos intangíveis, em seus aspectos e nos lugares simbólicos da cultura, que permitem a construção de cidades imagináveis (LIMEIRA, 2006).

Uma cidade imaginada, experimentada e redesenhada, se afirma como fluxo, e que se reinventa constantemente. Algumas das mais recentes demonstrações desta afirmação, em Brasília, são exemplificadas por ações de intervenção e apropriação do espaço que simbolizam e reivindicam o direito à cidade. São propostas de ocupação urbana que promovem o encontro de pessoas em espaços livre, a céu aberto como o Picnik no Calçadão, um encontro em espaços bucólicos da cidade para piqueniques; o Céu com Cinema, um evento de projeção de filme inspirado no gramado desocupado da 207 norte e o 4zero5norte que converte os espaços entre os blocos das comerciais da 405 norte em verdadeiras praças que unem pessoas à música, gastronomia, mostra de artesanato e descanso em seus gramados, de acordo com um morador da cidade sobre os 
promotores deste último evento citado, são eles "os responsáveis por deixar a nossa cidade mais bonita e os nossos fins de semana mais felizes"

Figura 60: Picnik no Calçadão

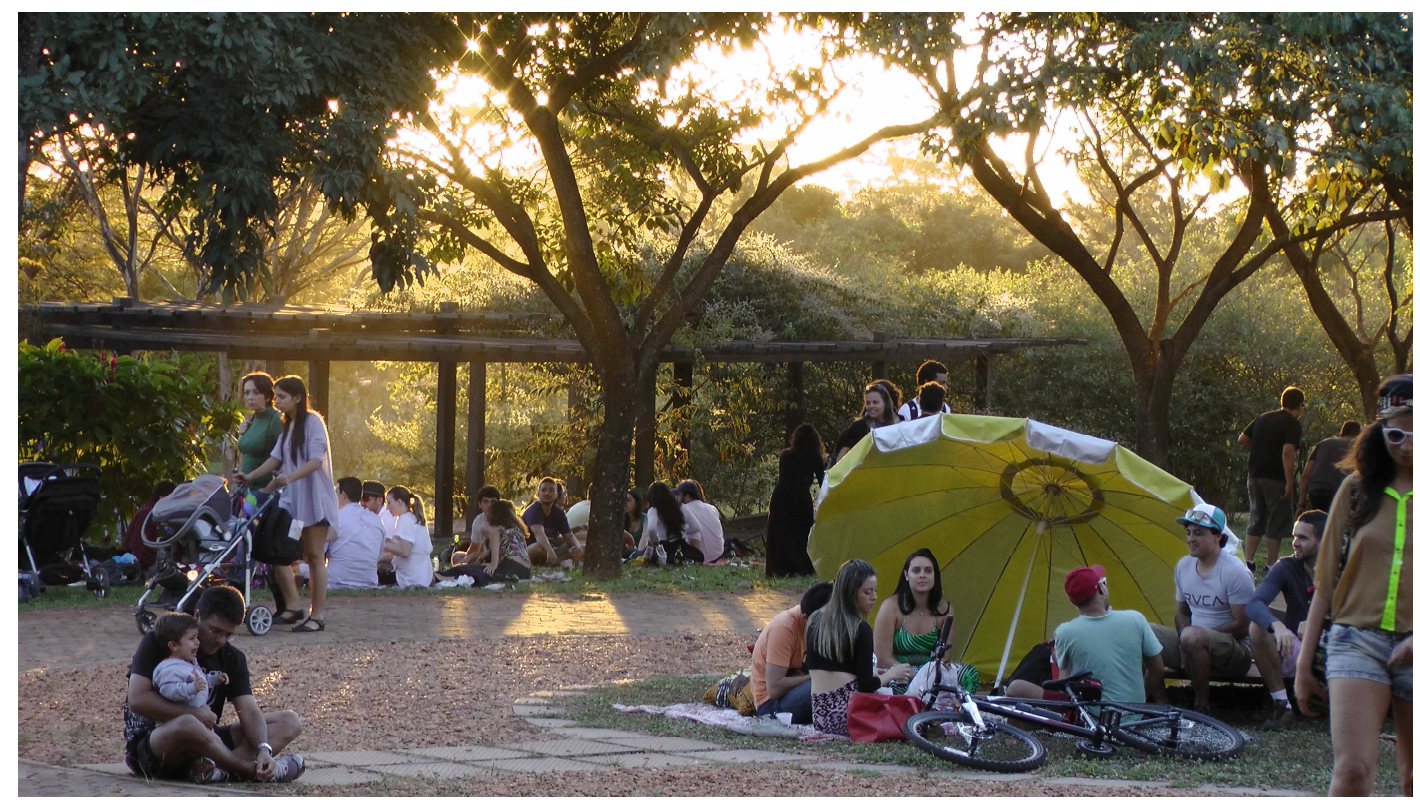

Fonte : Tatiana Terra (2013)

Figura 61: Céu com Cinema

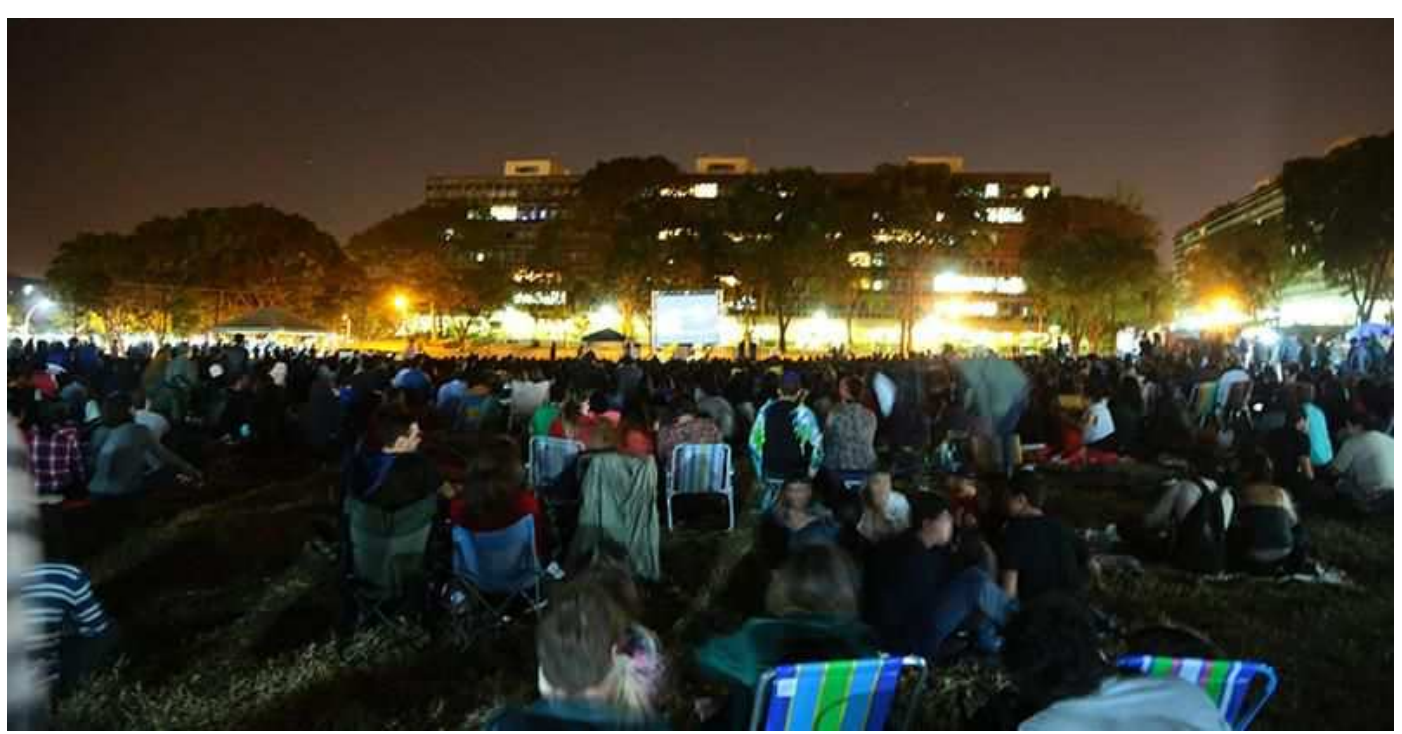

Fonte : Retrato Brasília (2014)

45 Comentário retirado do site Quadrado Brasília Publicado em 1 de outubro de 2014 por danicronemberger. Disponível em https:/quadradobrasilia.wordpress.com/category/la-se-vaimeu-salario/page/2/ 
Figura 62: 4zero5norte

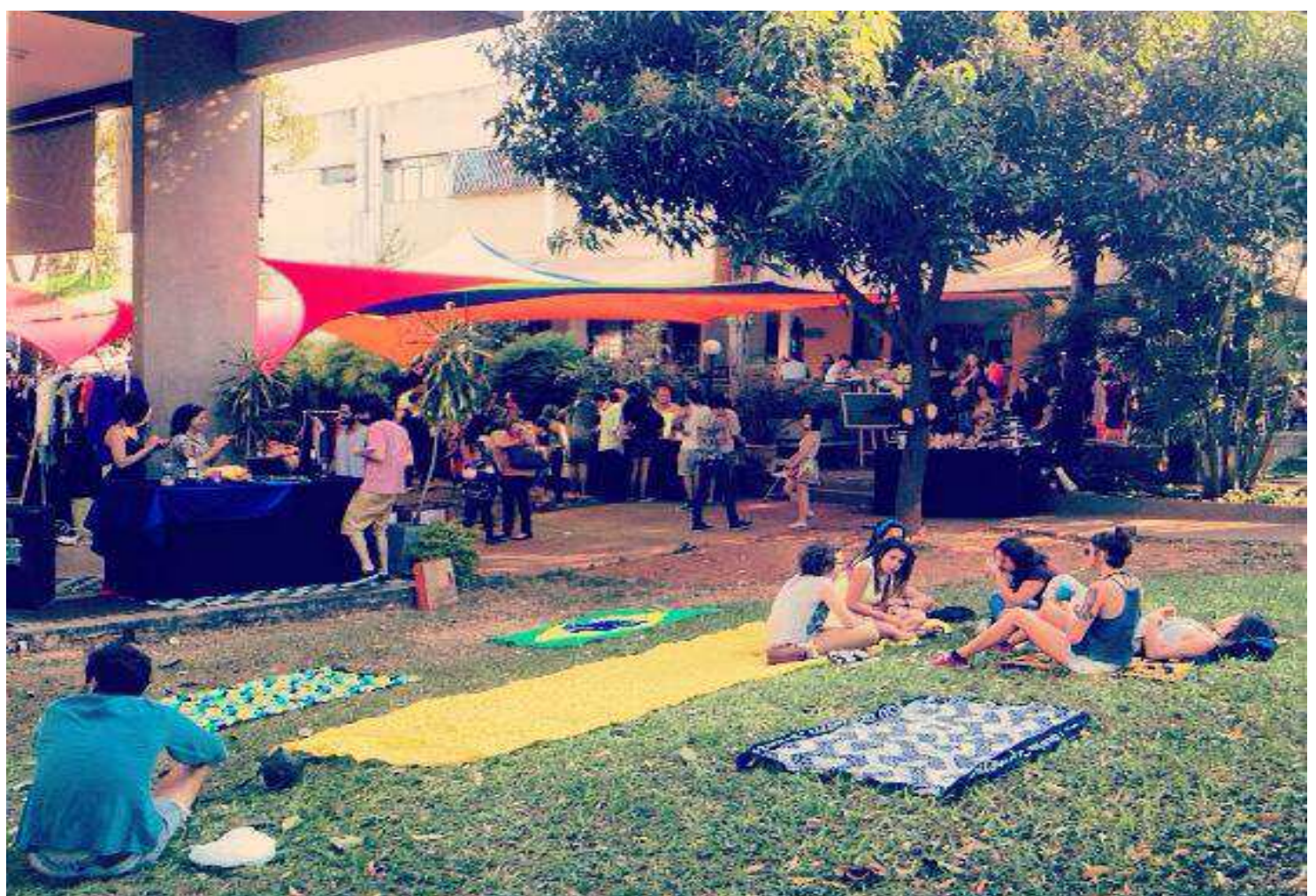

Fonte : Divulgação - Quadrado Brasília (2014)

Usufruindo da cidade, ela pode ser interpretada e compreendida, pois é experimentada. São os que se movimentam pela cidade que constroem nela inúmeras outras. As intervenções urbanas artísticas são exemplo disso, e além delas os eventos culturais, abertos a moradores e visitantes. Por eles, um terreno baldio se transforma em cinema a céu aberto, um comércio tradicional de repente abriga uma efêmera feira erótica, a galeria de arte se estabelece fora do setor cultural e redesenha uma superquadra, visitantes de uma feira voltam ao passado diante vitrolas e antigos vinis numa tarde de domingo no hall do primeiro cinema da cidade, passantes experimentam sua gastronomia na maior e principal avenida de carros e/ou mergulham em piscinas plásticas incorporadas nos gramados das autovias. 
Figura 63: Feira do Vinil

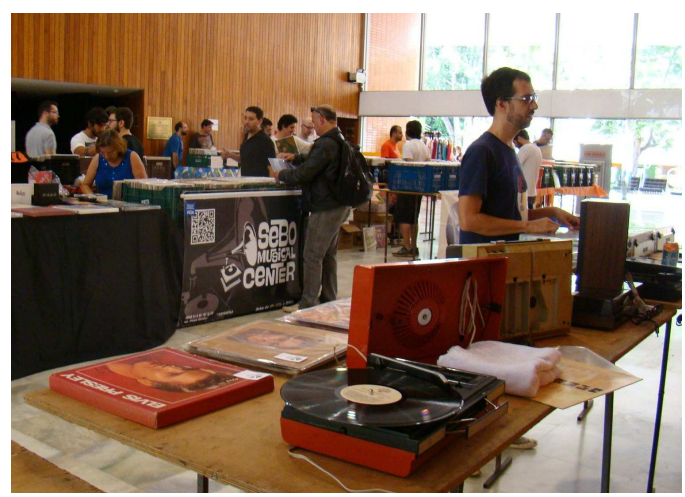

Fonte Simone Spíndola (2014)
Figura 64: Isoporzinho com piscina ${ }^{46}$

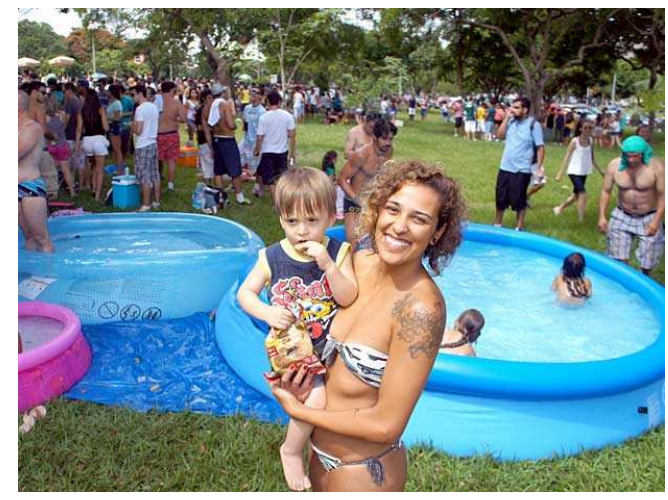

Fonte : Ricardo Moreira / G1 (2014)

$\mathrm{Na}$ cidade setorizada, dos espaços vazios, "sem gente" ${ }^{47}$, constantemente "acusada de fria, mortal, desesperante" (PENNA, 2002) pipocam manifestações de encontros sociais que, paradoxalmente, são possíveis pelo entendimento, mesmo que empírico, dos moradores em relação aos espaços livres, das escalas bucólica e residencial propostos no Plano, com isso, realiza-se "a função social dos espaços livres dentro da cidade (que) consiste em permitir que os indivíduos se reúnam" (MUMFORD,1960 apud CHOAY, 2005) $)^{48}$.

Ações desta qualidade caracterizam o "pensar na cidade como alargamento da imaginação" que deve "contribuir para a apropriação do tempo, do espaço, da vida, do desejo" quando inclusive pensamos sobre se ter esperança nas nossas cidades (LIMEIRA, 2006). Fazendo então, uma relação do urbanismo ao significado da arquitetura por Richard Neutra ${ }^{49}$, tem-se esta como "instrumento do destino humano não apenas porque provê as nossas necessidades, mas também porque condiciona e dá forma a nossas reações". Se jovens moradores da cidade a entendem como possibilidade de renovação diária dos seus espaços, seriam eles os próprios "arquitetos do seu

\footnotetext{
${ }^{46}$ Moradores usam piscinas para motivar uso de áreas públicas no DF Grupo ocupou área às margens do Eixo Sul, via interditada aos domingos. Uma das responsáveis pela iniciativa apoia mais 'contato' entre moradores. http://g1.globo.com/distrito-federal/noticia/2014/02/moradores-usam-piscinas-para-motivar-uso-de-areaspublicas-no-df.html / 09/02/2014 18h50 - Atualizado em 09/02/2014 18h52 .

${ }^{47}$ Uma das inúmeras máximas afirmadas em trabalhos acadêmicos, pela mídia e escritores em geral ou senso comum, catalogada por João Gabriel Lima Cruz Teixeira, no livro Brasília 50 Anos, Arte e Cultura. Como curiosidade outras máximas relacionadas à Brasília apresentada pelo autor: " não tem identidade", "brasiliense é um exilado", "paradigma da amplitude", "ilha da fantasia", "prisão ao ar livre", "assexuada", "paisagem d a insônia", "sempre domingo", "tem muito longe", "sem calçadas e bares", "sem esquinas".

${ }^{48}$ Esta citação aparece no artigo Landscape and Townscape, publicado na revista Landscape em 1960 e reeditado no conjunto de trabalhos publicados sob o título The Highway and city, Londres, Secker \&Warburg, 1964. In O Urbanismo, de Françoise, 2005.

${ }^{49}$ Reflexão de Richard Neutra in Quando mudam as capitais
} 
destino" que, na fala de David Harvey ${ }^{50}$ nada mais é que "adotar a imagem do arquiteto como metáfora de nossa condição de agentes no curso de nossas práticas cotidianas e, por meio delas, efetivamente preservar, construir e reconstruir nosso modo de vida" (HARVEY, 2004 apud LIMEIRA, 2006).

Figura 65: Moradores desfrutam dos espaços vazios em gramado beira lago (2014)

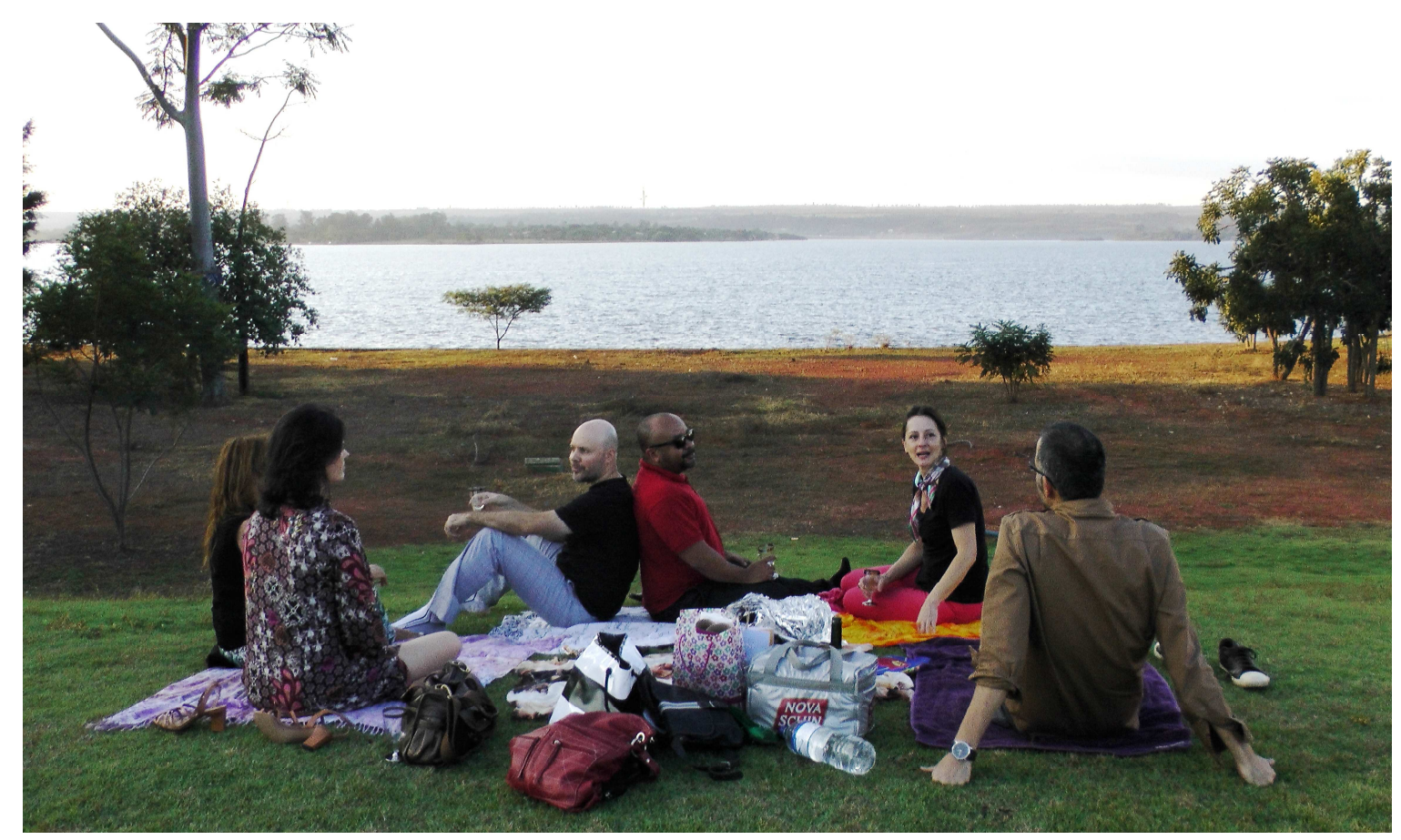

Fonte: Tatiana Terra (2014)

Em 1984, ao revisitar a cidade, Lucio Costa comenta que poderia ser ela "uma flor de estufa",51, mas não é, pois foi tomada, apropriada pelos moradores e trabalhadores, "o sonho foi menor que a realidade" ${ }^{\text {. }}$. Hoje, o arquiteto, poderia igualmente admirar-se ao se deparar com todas estas expressões que surgem senão pela singularidade do seu desenho urbano e sua arquitetura junto ao entendimento dele por seus habitantes, residentes, trabalhadores, turistas, moradores da cidade. Brasília, ainda aos cinqüenta e quatro anos de idade, fortalece seu desenho por suas características

50 David Harvey - Espaços da Esperança. São Paulo: Edições Loyola, 2004 in Metodologias multidimensionais em ciências humanas.

51 Isto tudo é muito diferente do que eu tinha imaginado para esse centro urbano (...) Quem tomou conta dele foram esses brasileiros verdadeiros que construíram a cidade e estão ali legitimamente. É o Brasil...eu fiquei orgulhoso disso, fiquei satisfeito (...) Eles tomaram conta daquilo que foi concebido para eles. Então eu vi que Brasília tem raízes brasileiras, reais, não é uma flor de estufa como poderia ser, Brasília está funcionando e funciona cada vez mais. Na verdade o sonho foi menor que a realidade. A realidade foi maior, mais bela. Eu fiquei satisfeito, me senti orgulhoso de ter contribuído. Declaração de Lucio Costa em entrevista para o Jornal do Brasil in Com a palavra Lucio Costa.

${ }^{52}$ Ibdem 
quando se redesenha pelas intervenções e apropriações - movimentos urbanos culturais - que abusam de seus espaços. Movimentos que não só fortalecem a idéia da criação da cidade, colocada como invenção, mas que sinaliza o pensamento de Mumford (1945), apresentado anteriormente de que "a mente adquire forma na cidade assim como as formas urbanas condicionam a mente humana". Assim, podemos entender com base nas expressões apresentadas que, cidades e moradores estabelecem mesmo esta relação dialética de forma, pensamento e ação. É o desenho da cidade como "circunstância favorável" à vida coletiva e aos movimentos coletivos de Mumford.

Os planos das cidades se convertem em símbolo de relação social (...) quando este drama está claramente delineado e conta com cenário apropriado, em todas as manifestações da vida se sente o ímpeto da energia social: o comer, o trabalho, o matrimônio e o sonho não têm menos importância que antes, senão muito mais; a vida, apesar dos seus momentos dolorosos, tem o porte e a unidade de uma obra de arte coletiva. A tarefa de criar esse cenário, de realizar essa visão e a de vivificar cada uma das capacidades individuais, mediante a articulação, um conjunto inteligente e esteticamente estimulador, é a essência da arte da construção das cidades. E menos que isso não é suficiente (MUMFORD, 1945).

Assim, considera-se que Lucio Costa fez com seu risco a expressão de um pensamento ético. Para melhor se entender esta afirmação, convém abordar a essência do desenho. Fernando Chuí, poeta, músico e desenhista em sua conversa com a artista e filósofa Márcia Tiburi ${ }^{53}$ comentou que

o desenho é o gene do pensamento; é o que vem antes; a vontade se antecipando ao desejo. O desenho é para o pensamento estético o que a voz é para a música. A redescoberta dessa voz deve vir pelo risco, ou seja, pelo traço. Um desenho só ocorre quando o olho o revela (...) o desenho (...) não é uma ação das mãos, é uma ação do olhar ${ }^{54}$ (CHUí apud TIBURI, 2010)

"O desenho é um ato político" 55 , replica Márcia a Fernando. Como um ato político, ou como modo de pensar o projeto e o mundo, que Cavalcanti (2010) discorre sobre o ato de desenhar do arquiteto. Ele afirma que seu risco está ligado ao mundo das ideias e une técnica a ética. Traz Lucio Costa como exemplo concreto dessa realidade, sobre ele afirma uma estética - elaborada pela "técnica dentro de uma aplicação ética".

\footnotetext{
${ }^{53}$ Conversa registradas em Diálogo/ Desenho / de Márcia Tiburi, Fernando Chuí. - São Paulo: editora Senac São Paulo, 2010.

${ }^{54}$ Ibdem

55 Ibdem
} 
Outro autor, Grinpum (2007), corrobora da mesma análise, pois vê no risco intencionalidade, diz que o ato de desenhar é mesmo "lançar a linha no espaço (...), estabelecer um continente, que aparentemente não contém nada, mas onde pode caber tudo (...)", nesse processo cria relações entre coisas e determina pesos e valores, "falar de objetos e fazê-los falar". A importância do desenho se vê na prática das escolas italianas, onde ele se imprime como matéria tradicional dos programas vigentes em suas escolas, ainda hoje. É entendido como educação de base no intuito de ensinar "o ambiente físico em que vivem: ler e escrever o mundo dos objetos materiais, além do mundo dos discursos, de modo a poder discuti-lo, modificá-lo, e não apenas suportá-lo passivamente" (BENEVOLO, 2012).

Imbuída de uma certa dignidade e nobreza de intenção (COSTA,1991), Brasília foi desenhada para valorizar o ser humano, e nela privilegiar a conexão do espaço com o corpo. A Escala Residencial como exemplo desta afirmação, proporciona a vivência de práticas mais humanas, onde "o homem é respeitado em seu 'habitar', sem se perder num labirinto administrativo ou se perder numa rede de comunicações ${ }^{56}$. Um desenho dedicado aos cidadãos que habitam a cidade, nas relações do corpo com o espaço e a paisagem.

Do risco para a proposta paisagística do plano-piloto incorpora-se o imenso céu do planalto, ele torna-se como parte integrante e onipresente da própria concepção urbana - os "vazios" são por ele preenchidos; a cidade é deliberadamente aberta aos 360 graus do horizonte que a circunda. ${ }^{57}$

\footnotetext{
${ }^{56}$ Declaração de Stamo Papadaki, membro da comissão julgadora para escolha do Plano Piloto de Brasília, disponível no livro O Concurso de Brasília, de Milton Braga, 2010.

${ }^{57}$ Projeto de Lucio Costa disponível no site do IPHAN -

http://portal.iphan.gov.br/portal/baixaFcdAnexo.do?id=280
} 
Figuras 66, 67, 68, 69, 70 e 71: representam céu, horizonte e os vazios da cidade
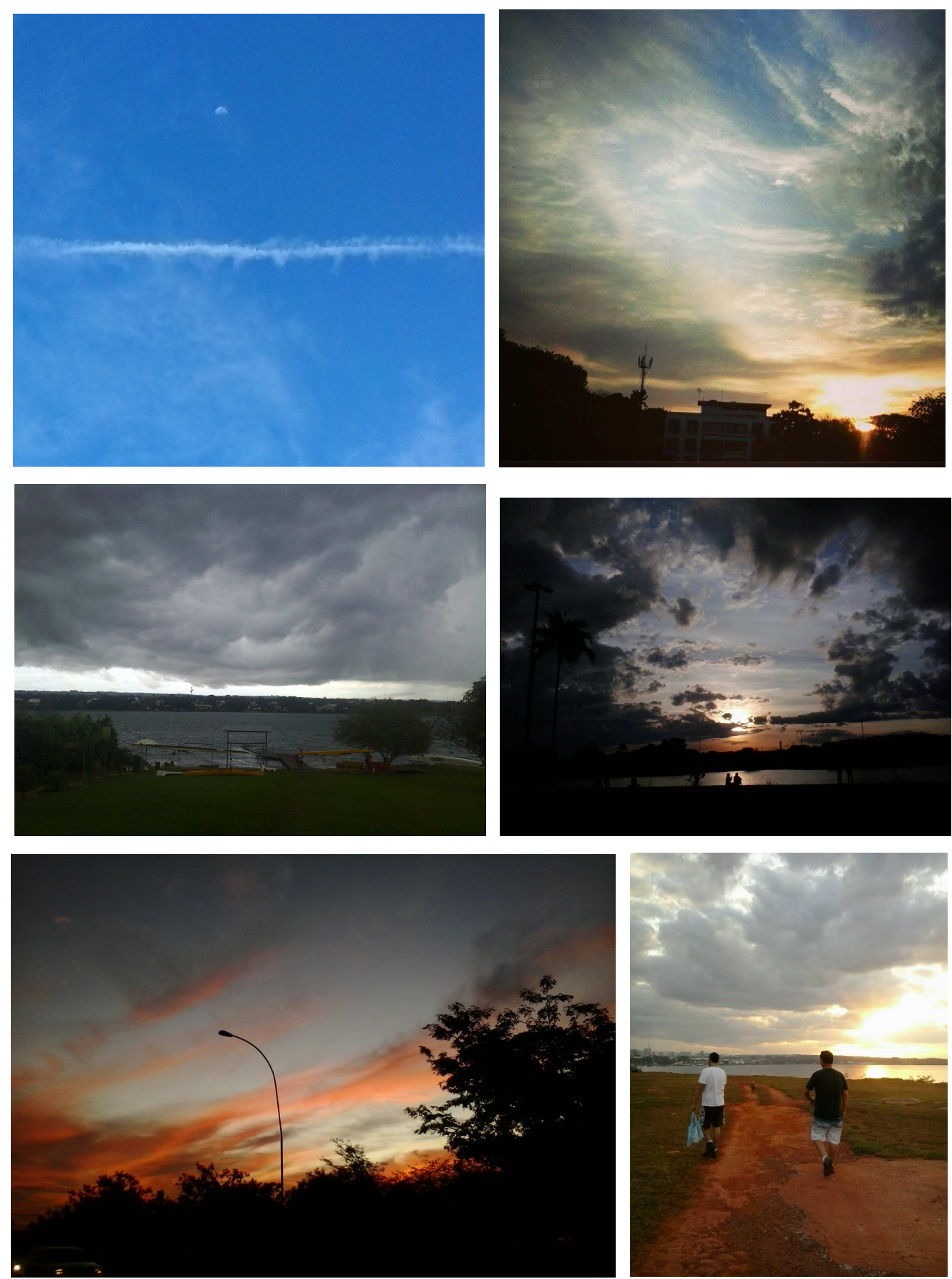

Fonte: Tatiana Terra (2014)

Incorporar o céu como parte integrante da paisagem, privilegia o horizonte e dialoga com seus espaços vazios. Se tomarmos como exemplo Nova York, que assim como Brasília, nasceu em uma vastidão de terras desocupadas, isto é, seu desenho antecedeu à povoação; observa-se a diferença do pensamento humanista. Na construção da cidade novaiorquina, diferentemente de Brasília, "em vez de olhar as estrelas, seus construtores consultaram os bancos" (SENNETT, 1994). 


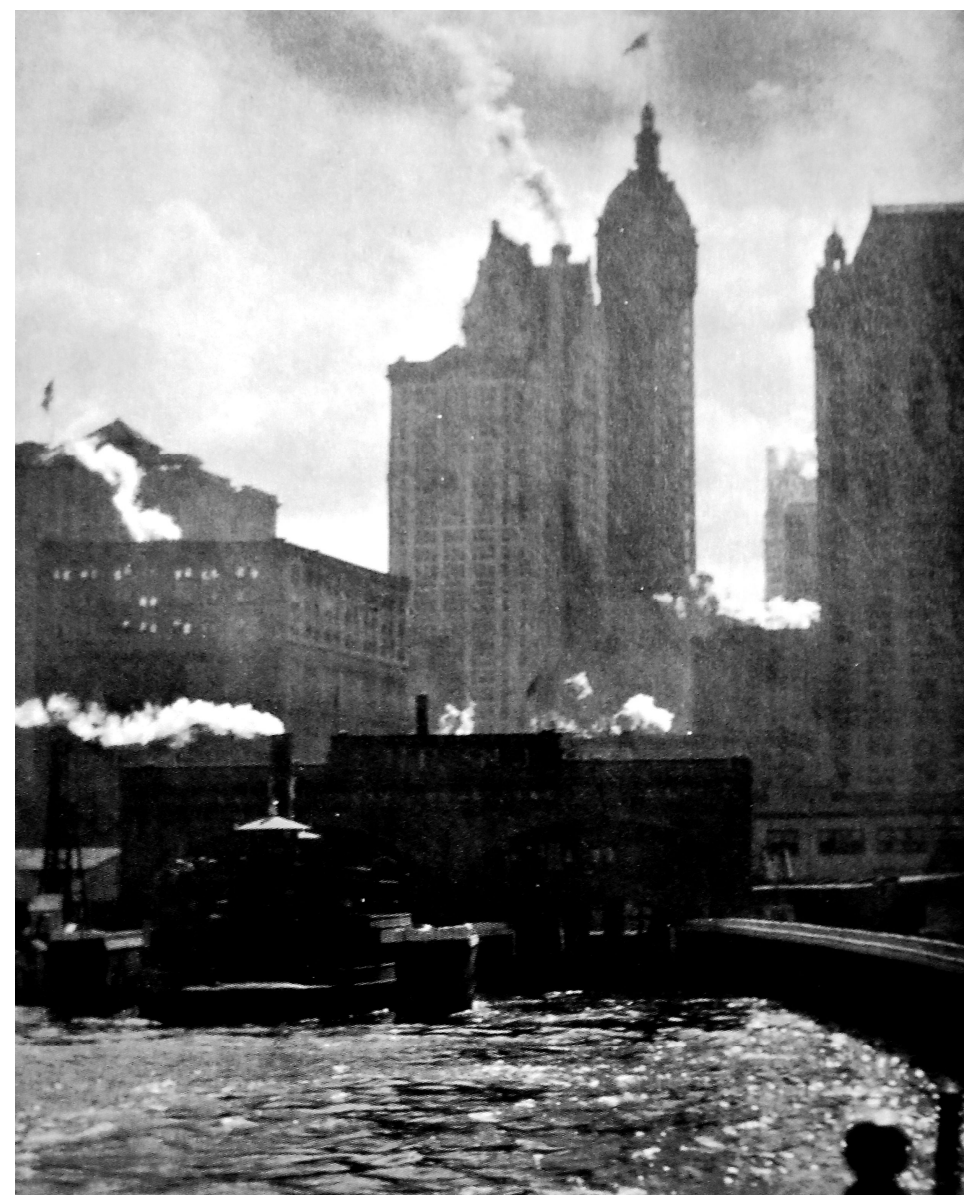

Fonte: Susan Wright - Georgia O’Keeffe - An Eternal Spirit (1996)

Segundo Sennett (1994), cidades que desconsideram a liberdade de movimento e privam o ser humano das saudáveis percepções e sensações corporais, são cidades "fragmentadas e excludentes" (SENNET,1994). Em seu livro Carne e Pedra, o autor comenta a necessidade do desenvolvimento das sensações físicas no espaço urbano, que só podem ser experimentadas por "um plano que respeita a dignidade dos corpos humanos" (SENNET,1994). Ele discorre sobre as cidades na contemporaneidade e considera que aparentemente estamos "condenados à passividade; à monotonia e ao cerceamento táctil do ambiente urbano" (SENNET,1994), um contraste aos tempos modernos que "privilegiam as sensações do corpo e a liberdade de movimento" (SENNET,1994). No entanto, ainda segundo Sennett (1994), as teorias modernistas não teriam sido aplicadas conforme seu ideal, pois "os arquitetos e urbanistas modernos haviam perdido a conexão com o corpo humano" (SENNET,1994), uma característica analisada pelo desenvolvimento das cidades de Nova York e Londres, por exemplo. Nova York, crescida à custa de constantes demolições e readaptações pela necessidade 
econômica, sempre aparece em nosso imaginário com seus arranha-céus, e Londres, que devido à sua rápida transformação, foi caracterizada sem vida, embora pulsada pelos ritmos das transformações frenéticas. A partir das cogitações do romancista E.M. Foster, Sennett (1994) chama a atenção para a sua "estúpida monotonia". Sua análise sobre as ponderações de Foster demonstra que o que ele pretendia evocar era a "apatia dos sentidos", presente, mesmo que oculta, na conduta cotidiana tipicamente urbana. Sennett (1994) comenta a invisibilidade da cidade pela apatia dos sentidos, ou seja, a cidade, que hoje, em sua maioria, entorpece os sentidos pela supressão das sensações corporais possibilitadas pela liberdade do movimento, uma tendência que a cada dia se observa nas atuais cidades que, em crescentes verticalizações, comprometem a experiência ativa do caminhante, o flanêur, conceito que abordaremos no próximo capítulo.

Diante da afirmação de Sennet (1994), em relação à homogeneização mundial das cidades e interferências de espaços subordinados a interesses econômicos é que Brasília precisa ser conhecida e preservada. Como a maioria das cidades, hoje ela também não escapa ao modelo de "desenvolvimento", submetida à ganância econômica e à obsessão exploratória do mercado imobiliário que mesmo com o "entrave" de sua inscrição como patrimônio mundial, tem pouco a pouco sofrido interferências na sua estrutura viária, na interação das escalas urbanas. O princípio das associações entre as unidades materiais e existenciais que caracterizam os espaços e o ser humano em (con)vivência merecem atenção e estudo.

Conhecer Brasília pela experiência da caminhada em seus espaços é considerála como possibilidade de visibilidade dos sentidos, em uma proposta que é muito próxima aos conceitos do Turismo enquanto deslocamento e viagem, no sentido de romper espaços (subjetivos também). É a viagem na cidade pela experiência do caminhar: o Erfabrung, palavra que vem do alemão antigo irfaran: 'viajar', 'sair', 'atravesar' ou 'vagar' e que curiosamente é uma das palavras alemãs que significam 'experiência' ${ }^{58}$. É a possibilidade de ampliar a percepção de quem trabalha e habita, como um turista na sua própria cidade, e que essa experiência possa ser proporcionada aos demais visitantes, para entendimento e proteção de Brasília, para defesa da não

\footnotetext{
${ }^{58}$ In Walkscapes, o caminhar como prática estética, 2013.
} 
negociação de suas áreas verdes, dos seus gabaritos, dos seus espaços vazios e da presença do céu, bem como para reforçar sua representatividade histórica e mérito urbanístico. Enquanto mérito urbanístico, evidenciar sua vocação às inter-relações humanas e meio possível de percepções do sensível tão necessários mas constantemente esquecidos pela concepção contemporânea de "habitar, viver, ocupar". É permitir o posicionar-se no meio em que se vive, meio este o qual todos pertencemos e simbioticamente existimos, e principalmente, para que o homem possa refletir sua real existência e sua própria significância, para uma possível relação de princípios de vivências sustentáveis ${ }^{59}$, na melhor expressão que a palavra sustentável pode significar.

59 Podemos conceituar Sustentabilidade, pela visão de Leonardo Boff, como "toda ação destinada a manter as condições energéticas, informacionais, físico-químicas que sustentam todos os seres, especialmente a Terra viva, a comunidade de vida e a vida humana, visando a sua continuidade e ainda a atender as necessidades da geração presente e das futuras de tal forma que o capital natural seja mantido e enriquecido em sua capacidade de regeneração, reprodução, e coevolução." Disponível no site: https://leonardoboff.wordpress.com/2012/01/15/sustentabilidade-tentativa-de-definicao/ 


\section{III - ESPAÇO PERCORRIDO}

\section{CAMINHAR, UMA OCUPAÇÃO EM MOVIMENTO}

A paisagem é um sache de sabores, cores, cheiros, onde o corpo fica infuso

Frédéric Gros

De uma cidade, não aproveitamos as suas sete ou setenta e sete maravilhas, mas a resposta que dá ás nossas perguntas

Italo Calvino

Figura 73: Caminhando na cidade

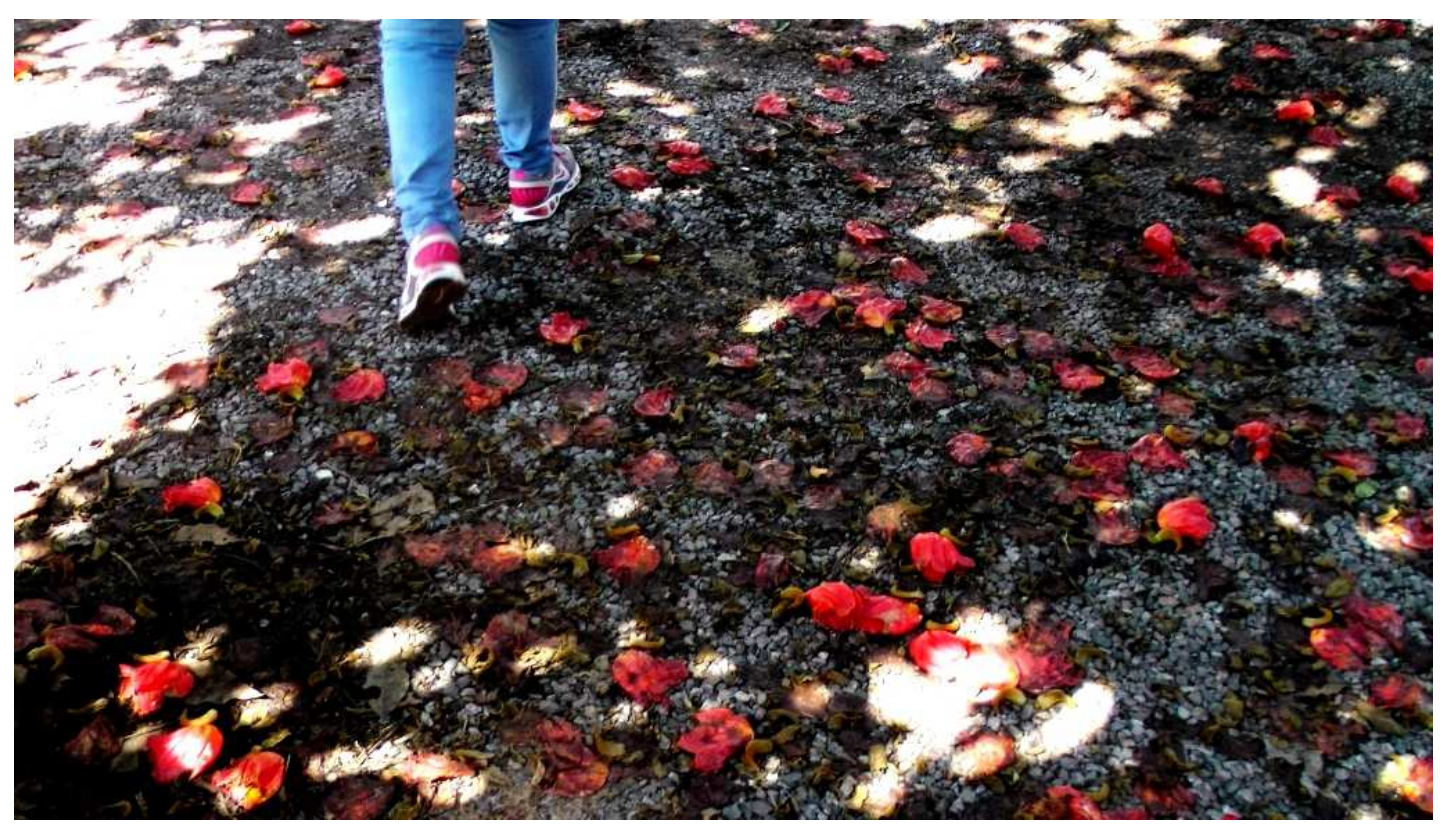

Fotografia: Tatiana Terra (2014)

Como é realmente a cidade sob esse carregado invólucro de símbolos, o que contém e o que esconde? (CALVINO,1990). O que tem e o que abriga a cidade de 
Brasília? Como conhecê-la para além dos cartões postais? Sugestão: amplie o mapa, crie uma rota inusitada, faça um passeio pelas suas Entrequadras, de preferência, a pé.

Para trazer o caminhante à cidade de Brasília / Plano Piloto, definiremos primeiramente quem ele é e o que ele faz. Podemos subitamente relacionar um caminhante àquele que caminha pela prática esportiva, por cuidado à saúde ou mesmo àquele que simplesmente passeia como o flâneur ${ }^{60}$, que por Baudelaire, foi evidenciado quando se pensa em um caminhante na cidade. Gros (2010) em seu livro Caminhar, uma filosofia, intitula já em seu primeiro capítulo, a primeira afirmação que auxilia na definição desta ação: “caminhar não é um esporte”. Quando o autor diferencia o esportista do caminhante, ele alude o primeiro a um caminhar que é motivado pela competitividade, em um mundo de números, técnicas, regras, estudos, esforço e disciplina, para um bom desenvolvimento de uma prática. Uma ação onde há sempre um vencedor e um vencido e que, vinculado ao esporte, se associa ao consumo de marcas e imagens, controlado pelo dinheiro, movido pela artificialidade. Mas quando ele pensa no caminhar como o ato de colocar um pé na frente do outro, ele prescreve um encontro: do caminhante com a paisagem. Então o caminhante ultrapassa resultados e números, dispensa artefatos esportivos e aproxima seu movimento a uma brincadeira de criança, "não se faz nada ao caminhar, só se caminha", tão simples que para sua execução são necessárias apenas duas pernas, e tudo mais se apresenta supérfluo. Gros (2010) relaciona a ação com a infância, diz que nos sentidos da eternidade infantil, há uma alegria em existir, um maravilhar-se com o tempo, com o sol, com o céu em brilhos e cores e com as árvores majestáticas, "quando se percebe as maçãs do rosto ao vento", sensações que são resgatadas na caminhada - um ato que dispensa qualquer requisito de experiências ou competências anteriores. Mas o autor alerta que é preciso desacelerar, promover o encontro com as sensações, estimular a percepção do tempo e do espaço: deve-se andar devagar, para que se possa observar "a imensidade do céu, o viço das paisagens", para que seja possível alongar os dias ${ }^{61}$ ou mesmo descobrir "a força imensa

\footnotetext{
${ }^{60}$ Expressão que surge na França, no século XIX e reporta a "alguém que perambula sem compromisso por uma cidade, alguém que percorre as ruas sem objetivo aparente, mas secretamente atento à história dos lugares por onde passa e à possibilidade de aventuras estéticas" in O FLÂNEUR - Um passeio pelos paradoxos de Paris de Edmund White (2001).

${ }^{61}$ Gros comenta que "A ilusão da velocidade é acreditar que ela faz ganhar tempo (...) fazer as coisas em duas horas ao invés de três acreditando que se ganha uma hora é um cálculo abstrato (...) pois a precipitação e a velocidade aceleram o tempo, que passa mais ligeiro e as duas horas apressadas encurtam o dia".
} 
das noites estreladas". Receber a liberdade suspensiva que a caminhada oferece, imergir nesta “desconexão” provisória" ou seja, naquela onde fardos e compromissos são esquecidos por um tempo. É o caminhar relacionado com o vagar, o passear, que ao seu término, volta-se às inércias, estas "da pressa, do autoesquecimento, da desatenção pelos outros, da excitação e do cansaço". É caminhando que o caminhante é posicionado "na vertical do eixo da vida: arrastados pela torrente que jorra abaixo de nós". Esse caminhante não quer ser alguém, nem quer ter um nome, nem quer a obrigação social de uma imagem. Quem caminha, renuncia, em defesa da mais alta liberdade. Renuncia ao que se tem para em seguida ganhar o novo.

Quando o filósofo analisa o caminhar, associa o ato a demais conceitos, um deles, o habitar - esta condição essencialmente humana. Diz que, se caminhar é "estar do lado de fora", inverte-se a noção generalizada de habitar a casa, o espaço fechado. É caminhando que o sujeito avalia as dimensões da moradia, quando se caminha, lentamente vai se tomando posse do espaço e se mora na paisagem. Vivenciar a cidade e seus espaços pela percepção possibilita um maior conhecimento e compreensão da cidade como espaço de habitar. Shelle (2001) afirma que para se bem habitar, é preciso antes de tudo "habitar de outro modo o pensamento" o que

\begin{abstract}
implica seguir as linhas que fogem por todos os lados e que afirmam a invenção de existências singulares para além dos espaços dados ou dos dados sobre o espaço. Existências que se explicam, desdobram por meio de uma ética e uma estética e que, confrontando as condições da experiência possível, afirma a vida em sua heterogeneidade como condição da experiência real (GODOY apud DELEUZE, 2013).
\end{abstract}

"Caminhar através da paisagem (...) deriva um primeiro mapeamento do espaço, bem como a atribuição de valores simbólicos e estéticos do território que levará ao nascimento da arquitetura da paisagem" (CARERI,2013), ou seja, a arquitetura entendida como percepção e construção simbólica do espaço. A arquitetura dos monumentos é a construção física do espaço. 
Figuras 74 e 75 Caminhantes na cidade e caminhos do desejo
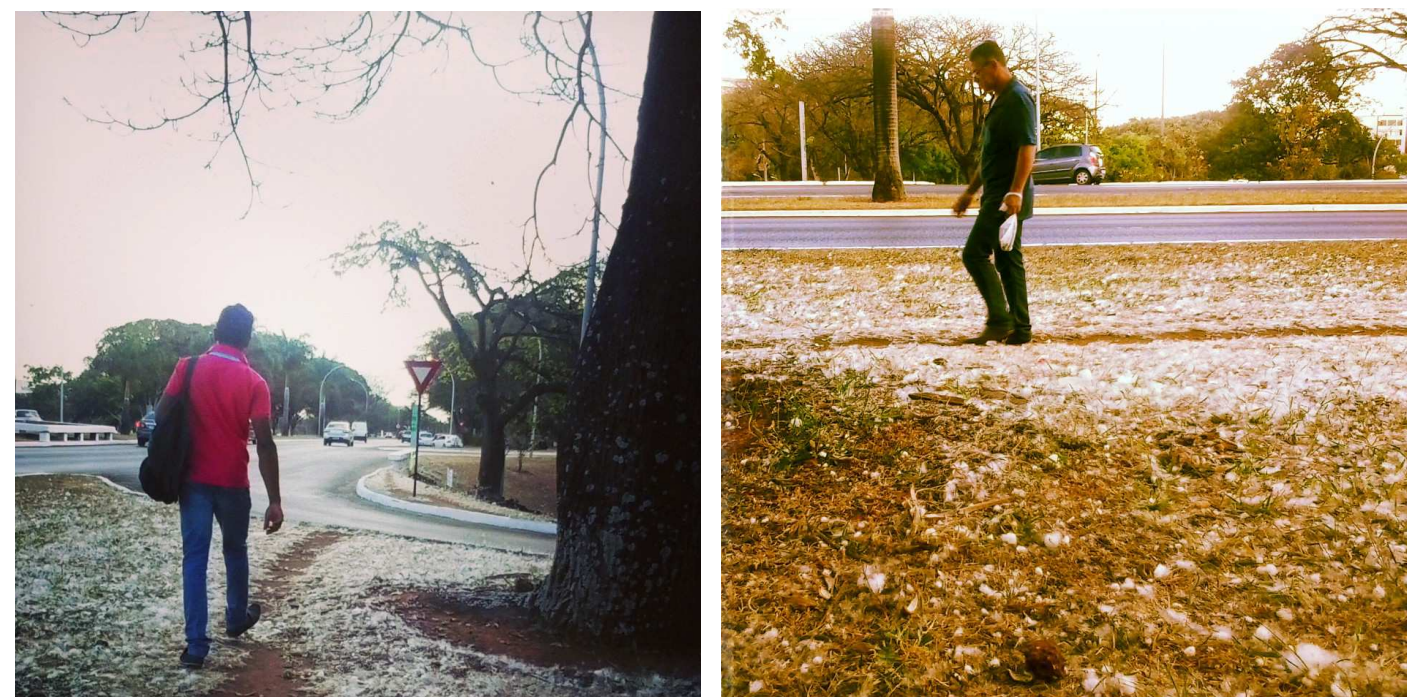

Fonte: Tatiana Terra (2013)

Habitando a cidade e permeando seus espaços, com um pé na frente do outro (Gros, 2010), pode-se pensar sobre a solidão e o silêncio. A cidade de Brasília, que apresenta amplos espaços e frequentemente é entendida como uma cidade vazia, onde não há multidões, nem intenso trânsito de pedestres, tem em todo seu eixo rodoviárioresidencial, um espaço à descoberta. De uma quadra a outra, na companhia das árvores. Os espaços públicos das Entrequadras de Brasília não apresentam as confusões de uma grande cidade, tudo é muito calmo, parece que tudo descansa.

Caminhar nas Entrequadras pode ser como caminhar na natureza, onde "caminha-se de mansinho em meio às altas árvores sombrias (...) (e) tudo cochicha baixinho"(GROS, 2010). Espaços "vazios não são tão vazios, mas cheios de rastros invisíveis" (CARERI,2013), no pensamento de Saint-Exupéry (2009), o que torna belo o deserto, é que ele esconde um poço em algum lugar, como nas lendas dos tesouros escondidos por alguém jamais descobertos, os lugares onde há algo a se descobrir, tornam-se belos pelo invisível. 
Figuras 76 e 77: Caminhante na cidade

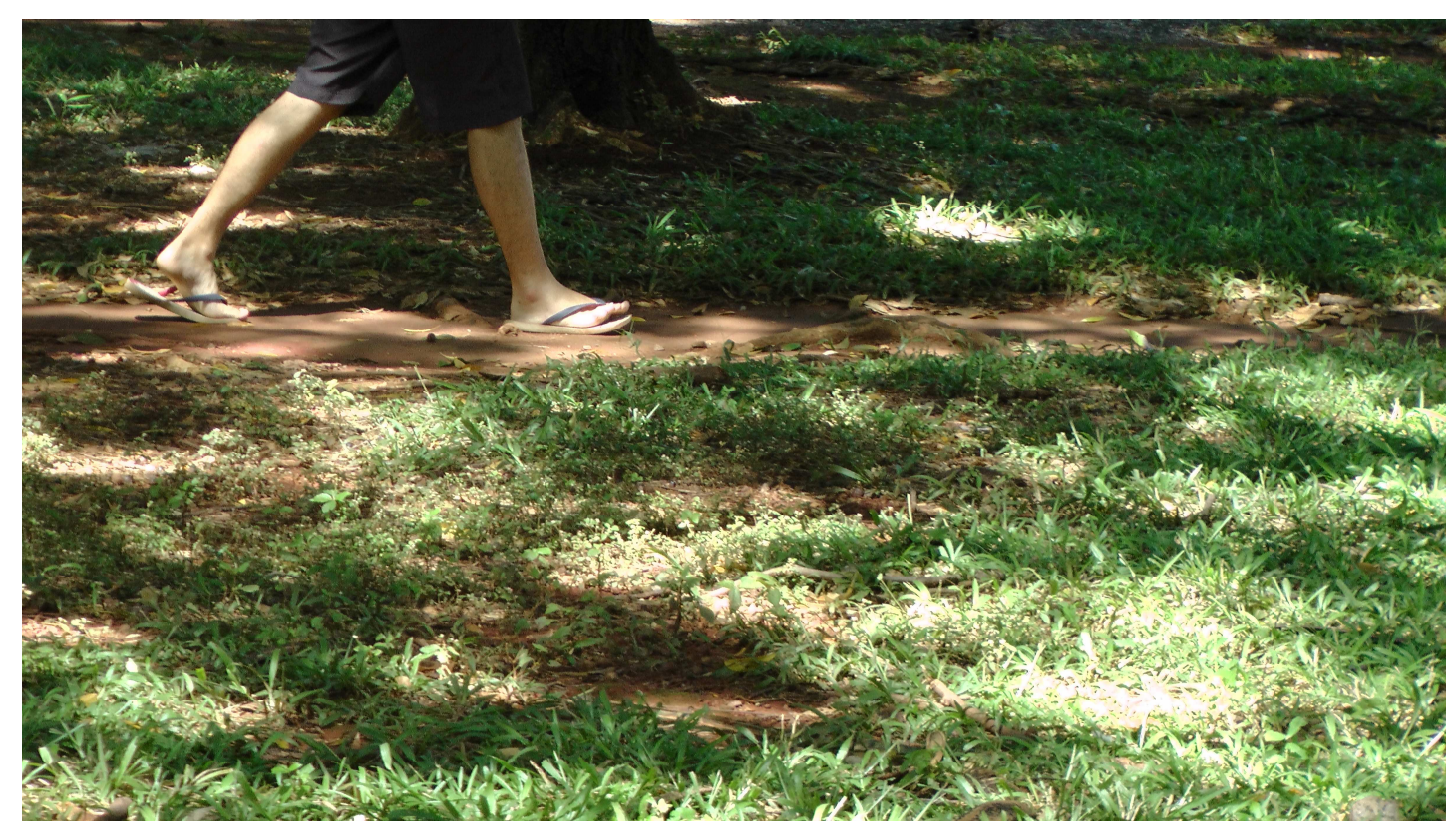

Fonte: Tatiana Terra (2014)

É assim que na paisagem vasta e "vazia” de Brasília, ao contrário da solidão, a natureza fala, no entanto é preciso estar disponível a esta comunicação.

Tudo fala conosco, nos cumprimenta, chama nossa atenção: as árvores, as flores, a cor dos caminhos. O sopro do vento, o zumbindo dos insetos, o curso do riacho, o impacto das pisadas sobre a terra (...). Até mesmo a chuva. Uma chuva leve e suave é acompanhamento permanente, um murmúrio que se escuta (GROS, 2010).

Para Gros (2010) ao caminhar se visita os espaços, conquistando sua simpatia, a simpatia de tudo que está vivo: flores e árvores e então é impossível se sentir só, porque caminhando estabelecemos um diálogo entre o corpo e a alma. A gente está sempre "conversando" com a gente mesmo. "É impossível estar só quando caminhamos, de tanto que dispomos de coisas ao alcance dos olhos, que nos são dadas, que nos são tomadas de posse inalienável da contemplação (...) tudo isso que vejo, se estende ao meu olhar, me pertence (...) o mundo pertence a mim, existe para mim, está comigo". E tudo está então relacionado aos modos de ver a paisagem no espaço. 


\section{ESPAÇO, PAISAGEM E OLHAR}

Caminhar é de toda forma transpor espaços e assim, ao cruzá-los o caminhante dilata suas sensações e agrega significados únicos e pessoais ao espaço percorrido, em um diálogo ímpar entre o olhar e o observado, já que cada indivíduo é pleno de referências pessoais prévias. O espaço observado torna-se criação própria, a ele são atribuídas novas significações em uma reconstrução simbólica por recortes e seleções do olhar, em busca da paisagem.

No sistema interpretativo da Geografia, Espaço é um "conjunto indissociável de sistemas de objetos e de sistemas de ações (...) reúne a materialidade e a vida que a anima (SANTOS, 2002)". Diferencia-se então de configuração territorial, não têm o mesmo significado. Assim como o espaço não é a configuração do território, o espaço do corpo ultrapassa os limites dos contornos visíveis, o espaço "não se reduz para nós a relações geométricas" (MINKWSKI apud BETTANINI, 1982), e a experiência corporal não se limita ao contorno do corpo, pois "a experiência do mundo nos aparece na medida em que nós estamos no mundo pelo nosso corpo e retomando contato com o corpo e com o mundo reencontraremos a nós mesmo (MERLEAU-PONTY apud BETTANINI, 1982). O lugar habitado, pode ir além do corpo situado no espaço ocupado - espaço físico (BOURDIEU, 1999).

Paisagem e espaço também não são sinônimos. A paisagem para Milton Santos (2002) é um conjunto de formas que num dado momento, exprimem as heranças que representam as sucessivas relações localizadas entre homem e natureza (....) é apenas a porção da configuração territorial que é possível abarcar com a visão (...) e se enquadra nas categorias analíticas internas do espaço - e o que está externo a ele são as técnicas, a ação, os objetos, a norma e os eventos, a universalidade e a particularidade, a totalidade e a totalização, a temporalização e a temporalidade, a idealização e a objetivação, os símbolos e as ideologias. "A paisagem não é apenas um conceito de unidade espacial, mas de sistemas de referências qualitativos, onde a inter-relação e a transposição de 
vários planos (físico, vital, espiritual) criam a sua identidade, a sua imagem própria" (SEIBERT,1978 apud GUIMARÃES,2012).

O espaço e a paisagem são teorias de muitas pesquisas que transitam entre diversas disciplinas. A artista plástica e orientadora desta dissertação, Karina Dias, em seu livro "Entre a Visão e a Invisão - por uma experiência da paisagem no cotidiano", analisa as questões do olhar e o vivenciar, e conceitua a paisagem como um como-verse. A paisagem para Dias (2010) é uma experiência sensível do espaço. É também uma passagem. E para Lucio Costa, é na passagem que se percebe a poesia da escala bucólica, a passagem se faz "sem transição, do ocupado para o não-ocupado", não há muros que delimitam o espaço, suas áreas livres arborizadas sutilmente delimitam os espaços, para que a vivência seja "natural e instintiva".

De acordo com Dias,

Experimentar a paisagem no cotidiano seria ativar um movimento do olhar onde ver e não ver se articulariam, onde os pontos de não-visão, de um certo estado de cegueira se transformariam em invisão, em uma visão interna. Não se trata de ver tudo, de ver em panorama, mas sim de se aproximar para habitar, de detalhar para se situar, para olhar no mesmo, no espaço de sempre, a diferença. Assim, a experiência da paisagem no cotidiano se forja na junção de uma certa maneira de olhar e dos caminhos percorridos. Ela tomaria forma a partir de detalhes corriqueiros que, por serem vistos e (re)vistos continuamente, se tornariam in-visíveis aos nossos olhos. Como então interromper, mesmo que momentaneamente, nossa percepção visual rotineira para que se instale uma percepção inusitada, uma experiência sensível do nosso espaço de todos os dias?

Para melhor se aproximar destas questões é necessário permitir-se outro olhar sobre a cidade, um olhar como o de Marcovaldo ${ }^{62}$, curiosamente "pouco adequado para a vida da cidade" (CALVINO, 1994), aquele olhar que não se atrai por avisos, semáforos, vitrines, letreiros luminosos, cartazes, mas que não deixa escapar os detalhes, que deseja

usar as ruas como ruas, isto é, caminhar no meio delas (...) pelo prazer de ver tudo de outro modo: as ruas como fundos de vale ou leitos de rios secos, as casas como blocos de montanhas íngremes, ou parede de

\footnotetext{
${ }^{62}$ Personagem do livro de Ítalo Calvino, Marcovaldo ou as Estações na Cidade (1994), que em seu percurso diário percebe que havia nascido cogumelos no canteiro da avenida onde ele pegava o bonde.
} 
escolhos (...) uma cidade de cascas, escamas, brotos e nervuras sob a cidade de verniz, asfalto, vidro e reboco (CALVINO, 1994)

que constrói o itinerário de seu passeio pela fileira de formigas, o vôo de um escaravelho perdido e o movimento sinuoso de uma minhoca, surpreendendo-se com as camadas de mofo formadas nas bancas de jornais (Calvino,1994).

Figura 78 : Detalhes na Paisagem

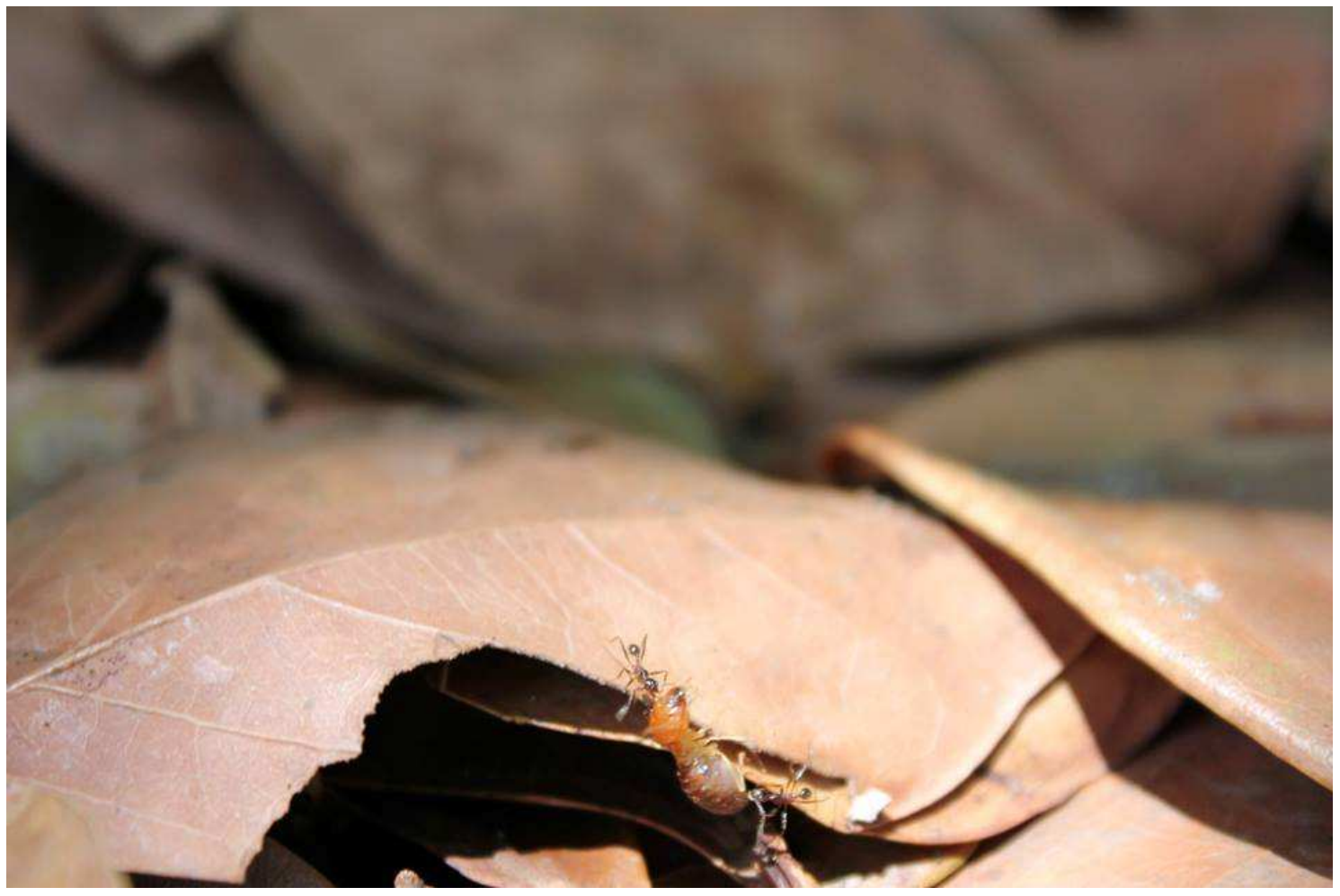

Fonte : Keisuke Yoshimura ( $1^{\circ}$ Lugar Concurso Brasília Bucólica - A experiência do Caminhar)

Um olhar cuja atenção corresponde à atividade de caminhar, do andar sem pretensão, para que o turista e o habitante da cidade se convertam no flâneur, que dispondo da vantagem deste olhar alerta, desenvolve ao caminhar pela cidade novas experiências urbanas. Dias (2010) cita em seu livro ${ }^{63}$ o pensamento de Merleau-Ponty, que se aproxima das afirmações acima:

o mundo está lá e parece nos dar a certeza de sua existência (....) mundo lá, exterior e disponível à apreensão de nossos sentidos, onde reina a "fé perceptiva" (crença tácita e espontânea da sua existência).

\footnotetext{
${ }^{63}$ Entre a Visão e a Invisão - por uma experiência da paisagem no cotidiano (2010)
} 
Esta certeza aprisiona o olhar pois a evidência é repleta de incertezas e imprevistos (Dias, 2010).

Se um modo de propiciar o olhar na paisagem pode se dar com o caminhar, aquele que caminha pela cidade, que encontra multidões, que percorre passagens, é como o poeta que transita por palavras e termos na construção de um texto. Esta comparação se encontra no artigo de Martha D’Angelo (2006) em sua análise sobre a leitura de Walter Benjamin pelas produções de Baudelaire. Ela aponta o flâneur como aquele que alcança o inusitado pelo olhar diferenciado que desvela o que antes passava despercebido. Comenta que "no lugar de passagem, entre a rua e a residência, ele se sentirá em casa"64, e em casa, ele se reconhece, pois "se nos sentirmos donos da paisagem, sentiremos-nos donos de nós mesmos". 65

Um possível desenvolvimento de um olhar mais apurado sobre o espaço pode se dar quando, o flâneur ou o caminhante, turista ou habitante, que olha e não apenas vê, desloca-se fisicamente na cidade, pelo prazer da experimentação e exploração dos pontos sensíveis da vida. E esse olhar resultado da percepção, modificado pela experiência afetiva do homem com o ambiente, resulta em uma nova visão de mundo, a compreensão do meio da experiência (TUAN, 2012).

Nietzsche (2005), um caminhante que usufruía dos espaços ao ar livre para, inclusive, inspirar sua produção escrita, relata a percepção de quem vê o mundo sem a experimentação do espaço: “....com o enorme aceleramento da vida, o espírito e o olhar se acostumam a ver e a julgar parcial ou erradamente, e cada qual se assemelha o viajante que conhece terras e povos pela janela do trem"66.

Uma comparação semelhante é feita por Gros (2010) sobre a aproximação ou mesmo a imersão do que se vê enquanto caminhante em oposição àquele que se desloca com velocidade. Ele diz que em um trem ou um carro, "vemos" uma imagem vir em nossa direção, é uma percepção do olhar ligeiro que acredita captar a imagem,

\footnotetext{
${ }^{64} \mathrm{Ibdem}$

${ }^{65}$ Citação de Lewis Mumford em Landscape and Townscape, artigo publicado na revista Landscape em 1960 e reeditado no conjunto de trabalhos publicados sob o título The Highway and city, Londres, Secker \&Warburg, 1964. In O Urbanismo, de Françoise Choay, 2005.

${ }^{66}$ Nietzsche. Humano demasiado humano.
} 
compreendendo-a. Já na caminhada "nada se desloca de fato: mas parece que a presença se instala lentamente no corpo". Tem-se então a necessidade de apurar o olhar, que em ritmo desacelerado promove maior contato com o espaço. Ou seja, um desenvolvimento apurado do olhar é possível quanto maior for o contato do sensível no espaço (GODOY, 2012). Em Nietzsche, encontramos algumas percepções que ele teve da paisagem, enquanto caminhante, e que chamou de recompensas:

\begin{abstract}
Mas depois virão, como recompensa, as venturosas manhãs de outras paragens e outros dias, quando já no alvorecer verá, na neblina dos montes, os bandos de musas passarem dançando ao seu lado, quando mais tarde, no equilíbrio de sua alma matutina, em quieto passeio entre as árvores, das copas e das folhagens lhe cairão somente coisas boas e claras, presentes daqueles espíritos livres que estão em casa, na montanha, na floresta, na solidão, e que, como ele, em sua maneira ora feliz ora meditativa, são andarilhos e filósofos. Nascidos dos mistérios da alvorada, eles ponderam como é possível que o dia, entre o décimo e o décimo segundo toque do sino, tenha um semblante assim puro, assim luminoso, tão sereno-transfigurado: - eles buscam a filosofia da manha.$^{67}$
\end{abstract}

A percepção do vivido se concretiza através da articulação de dois universos: o do espaço exterior e o do espaço corporal (VILLASCHI, 2011). Moradores da cidade, em conversas informais, relatam essa percepção articulada, um diz que a paisagem de Brasília não é beleza dada, é beleza conquistada e que caminhar por Brasília é se entregar a riqueza de formas, cores e texturas das árvores de cerrado encontradas no caminho, algo tão libertador quanto livrar-se de preconceitos e padrões herdados de pensamentos e comportamentos ${ }^{68}$. Nesse caso é clara a identificação do sujeito com o lugar e o seu desvelar, segundo Alves (2011) por sua atuação e apropriação e nesse sentido, o espaço torna-se lugar, pela identificação do sujeito com o que está ao redor pois adquire valores, exprime afetos e "sentimentos de pertencimento, num incessante tempo de construir e desconstruir do ser humano". Outra moradora estabelece também as articulações citadas por Villaschi (2011) e Alves (2011), entre o espaço exterior e o espaço corporal, quando diz que

Em Brasília, se você não está bem, dói. São muitos espaços abertos, me dá solidão, enquanto uma cidade grande me entorpece os sentidos

\footnotetext{
${ }^{67}$ Nietzsche. Humano demasiado humano. Parágrafo 638.

${ }^{68}$ Ramon de Córdova, brasiliense, livreiro. Morador da cidade.
} 
e me deixam mais segura, esses espaços amplos me trazem muita solidão, acredito que me obrigam a olhar pra mim mesma ${ }^{69}$

Sim, às vezes "um jardim desorienta muito mais do que acolhe"70, é a necessidade de olhar para si mesmo, "a experiência do lugar passa por uma antropologia do corpo" (MONGIN, 2009). Um processo de consciência do ser humano em relação ao espaço, em relação a si próprio, noção esta que é percebida pela vivência dos seus espaços, dialeticamente,

o espaço homogêneo, euclidiano, não está desvinculado do espaço orientado, corpóreo: a tal ponto que exprime o sentido do espaço orientado somente porque o recebeu deste: 'o espaço corpóreo pode tornar-se na verdade um fragmento do espaço objetivo somente se, em sua singularidade de espaço corpóreo, contiver o fermento dialético que o transformará em espaço universal (....) não somente o meu corpo não é para mim um simples fragmento do espaço como também para mim não haveria espaço se eu não tivesse um corpo ${ }^{71}$

Observar as relações afetivas entre os homens e o meio é buscar investigar a própria conscientização do homem nas possíveis inter-relações." O conjunto das relações existentes na experiência do 'vivido' inscreve-se e imprime-se em uma mesma paisagem, permitindo a construção de lugares de natureza subjetiva, não material, não tangível, porém, percebidos como uma parte da realidade ambiental vivenciada cotidianamente a partir dos processos simultâneos de interpenetração e interação (Guimarães 2002;2007 apud GUIMARÃES 2012).

A intencionalidade deste projeto, conforme apontado anteriormente, é não separar o caminhante morador da cidade do caminhante turista, visitante da cidade. Até mesmo, converter o habitante em turista. Para Urry (2012), o turista observa aquilo que o separa da experiência cotidiana, aquilo que está fora do que nos é habitual. Mas a ideia é aproximar o cidadão deste olhar para a cidade, que como "habitante desenvolve um relacionamento diferenciado com o local onde mora" (GASTAL \& MOESCH apud

\footnotetext{
${ }^{69}$ Marisa Góes, moradora e funcionária pública.

${ }^{70}$ Sophie Lê Ménahèze. Hospitalidade ao ar livre -. O livro da Hospitalidade- acolhida do estrangeiro na História e nas culturas. Alain Montandon, 2011.

${ }^{71}$ Tonino Bettanini em Espaço e Ciências Humanas.
} 
NÓBREGA \& DIAS, 2007), se torna um turista, e também promover a percepção do mundo para além da "janela" (Nietzsche, 2005), no intuito de descondicionar os padrões de olhares objetivados. Um convite a caminhada, a flâneurie, para que esse turista/flâneur possa ser qualquer sujeito que desvela a cidade enquanto caminha, um sujeito aberto à experimentações e possibilidades de descobertas:

O passeio a pé é a forma mais natural de flanar, porque depende inteiramente de nós e nos deixa totalmente entregues a nós próprios. Passeando a pé, encontramo-nos inteiramente livres para observar as coisas como bem nos aprouver, com total tranqüilidade de alma, podemos conciliar o movimento do corpo com as exigências do espírito e, quando quisermos que a observação aumente em um instante para que a visão de conjunto, basta um ligeiro deslocamento do corpo para abarcar todo o horizonte. Sem perturbar um mínimo sequer a atenção dirigida a um objeto preciso, podemos parar ou continuar a caminhar segundo as exigências do espírito. ${ }^{72}$

Seria possível em Brasília constituir essas relações? A relação da singularidade da paisagem de Brasília é descrita por Lucio Costa na arte de urbanizar, diz ele que "normalmente, urbanizar consiste em criar condições para que a cidade aconteça, com o tempo e o elemento surpresa intervindo" (COSTA, 2001) e que ao contrário das cidades que "se conformam e se ajustam à paisagem" (COSTA, 2001), Brasília no cerrado deserto encontra-se com um céu imenso e como em pleno mar, cria a paisagem (COSTA, 2001). Tuan (2012) em seus estudos sobre a percepção, atitudes e valores do meio ambiente nos lembra que os "laços emocionais e a capacidade de empatia estão condicionados à escala, ou relação do homem com o objeto", relação esta cuidadosamente pensada por Lucio Costa e que hoje é vivenciada pelos habitantes nos espaços residenciais.

\footnotetext{
${ }^{72}$ Schelle in "A arte de passear" (2001).
} 
Figuras 79 e 80: Caminhantes na cidade e caminhos do desejo

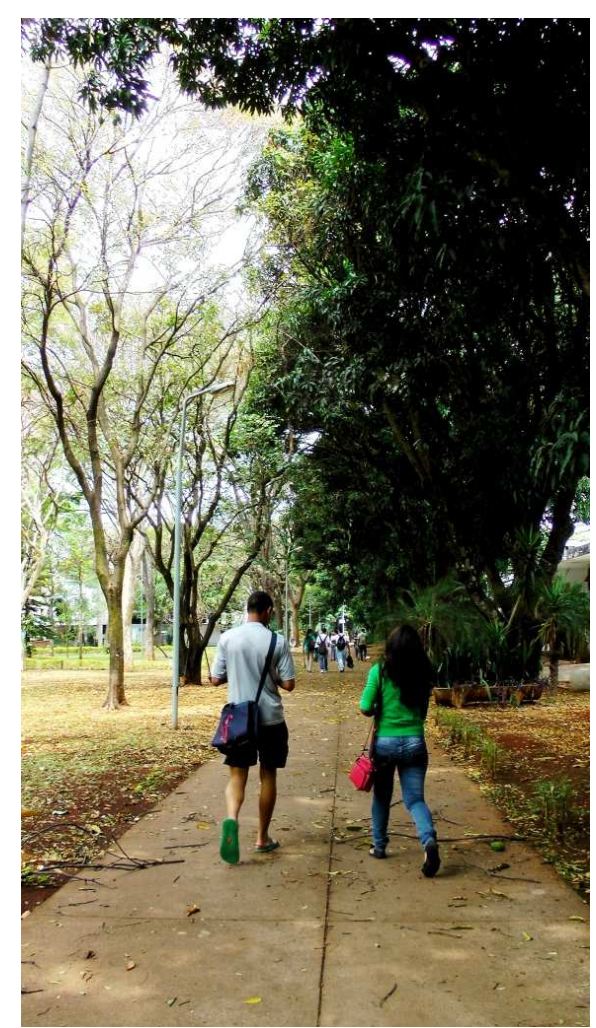

Fonte: Tatiana Terra (2014)

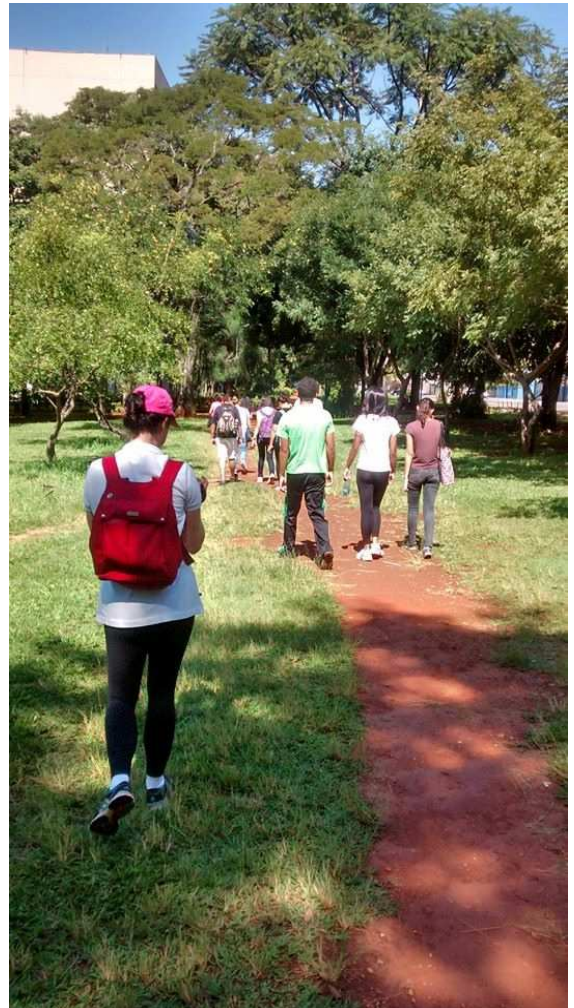

Fonte: Henrique Araújo (2014)

Ghione comenta que "a cidade é a criação mais apaixonante, complexa e contraditória do homem vivendo em sociedade.", portanto ver, perceber e sentir a cidade é não só considerar as relações de escala do homem no espaço (GHIONE, 2012) como também compreendê-la como um conjunto de representações simbólicas e refletíla como essência, onde se "articula o social e o mental, o teórico e o prático, o ideal e o mental" (LEFEVRE, 2008)

Em Brasília, quando moradores e visitantes se utilizam dos seus espaços bucólicos, criando seus roteiros de caminhada, seja passeando, seja se exercitando, seja simplesmente passando de um lugar a outro, por calçadas ou gramas, debaixo das árvores que dão à cidade uma característica de cidade-parque, podem entrar em contato com as teorias simbólicas sobre o espaço, aprimoradas pelo exercício da participação sensível denominado por Merleau-Ponty, "registros que ser realizam a partir do próprio corpo, no âmbito da experiência cotidiano” (MERLEAU-PONTY apud VILLASCHI, 
2012). Muitos que se utilizam deste espaço e vivenciam experiências pessoais de interação com a cidade refletem e verbalizam essas impressões.

São freqüentes as manifestações de afeto de quem vive em Brasília, em conversas informais ou em registros de imagens depositadas em sítios virtuais de interação social, são mensagens ou declarações que consideram percepções sobre a paisagem, são reflexos e reflexões dessa interação homem/cidade, vivências e experimentações que traduzem o espaço como possibilidade de experiências pessoais de afeto com o ambiente, o que na geografia humanista é conhecido como Topofilia ${ }^{73}$. Impressões da cidade que carrega o mito da "cidade que não foi feita pra caminhar" muitas vezes decorrem de um passeio feito a pé. Paradoxos existem. Mongin (2009) por exemplo, em A condição urbana: a cidade na era da globalização faz sua crítica à cidade: "Na criação de uma cidade nova, cuja tipificação é Brasília, o que acontece? Proezas arquitetônicas evidentes num tabuleiro urbano não menos evidente? Em Brasília, onde quer que estejamos, estamos em um lugar nenhum. Sem corpo.” Compara a cidade de Brasília aos lugares invisíveis, onde "se é possível caminhar, é impossível viver, por falta de tempo e de vida coletiva (...) fica-se "enclausurado." Em 2013, um artigo do Correio Braziliense publica uma entrevista com Ralf Gehre, artista renomado na cidade, e registra sua relação com ela

\begin{abstract}
Um dos mais consagrados artistas plásticos de Brasília, mora numa casinha de frente para a W3 Sul. É uma das primeiras unidades construídas na capital (...) Ele passa dias sem tirar o carro da garagem. Quase toda a rotina diária está ao alcance dos pés (...) "Se eu quero ir ao banco eu vou a pé. Quero fazer curso de inglês? De francês? De alemão? Dá pra ir a pé. Quero ir ao supermercado, à lavanderia? A pé. Quero pegar o metrô, quero ir a um bar, a um restaurante, encontrar amigos num café? Vou a pé. Quero ir a uma igreja, de qualquer religião, rezar? Vou a pé." Para o artista noção de cidade é "a riqueza de você ter uma cidade que alcança a pé." ${ }^{74}$
\end{abstract}

Jan Gehl, urbanista dinamarquês em declaração à revista Veja, comenta que “...foi projetada na escala errada, é monumental demais, desagradável para caminhar",75

\footnotetext{
${ }^{73}$ Conceito apresentado no livro Topofilia, de Yi-Fu Tuan (2012) que significa a "geografia voltada para o ser humano, em sua condição própria, que busca compreender as experiências geográficas em relação à sua dimensão existencial, psicológica, cultural e geográfica ao mesmo tempo".

${ }^{74}$ Artigo Sobre Ralph Gehre Entre Cobogós e Utopias, do Correio Braziliense 02/06/2013

${ }^{75}$ Veja, 29 de agosto de 2012
} 
Uma cidade vista de formas opostas? Sem dúvida "Uma pessoa que simplesmente vê é um espectador, um observador, alguém que não está envolvido com a cena." (TUAN, 2012). Quando um objeto é somente visto, ele parece distante, não causa emoção, ainda que muito próximos a nós, ${ }^{76}$. Para tanto a proposta da caminhada vem ao encontro de justamente propor a percepção da cidade e do espaço já que "o caminhar condiciona a vista e a vista condiciona o caminhar a tal ponto que parece que apenas os pés podem ver" (SMITHSON apud CARERI,2013), aplicada ao entendimento de que as "cidades são paisagens que cruzam diferentes espaços e tempos (...) traços de memória e imaginário, feitas de fluxos e (que) estão em trânsito permanente (PEIXOTO, 2004), ou seja, uma cidade "pode ser estável por algum tempo, por outro lado está sempre se modificando nos detalhes (...) não há resultado final" (LYNCH,2011).

Haveria então uma distância entre os pesquisadores, os distantes que vêem a cidade como objeto de pesquisa ou interesse econômico e seus freqüentadores? Aqueles que a olham e a experimentam? "Você sabe melhor do que ninguém, sábio Kublai, que jamais se deve confundir uma cidade com o discurso que a descreve" (CALVINO, 1997)

As mais diversas e divergentes opiniões estão entre aqueles que registram suas impressões. Um vídeo postado no Youtube 77 intitulado de "Traços da Cidade", mostra um morador da cidade, estrangeiro, que relata sua experiência em Brasília, ele menciona que o passeio que faz de sua casa até o trabalho é muito revelador:

\footnotetext{
"Eu tenho carro, mas eu só uso quando eu sou obrigado, mas é uma questão que evitamos. Porque se pode caminhar. Geograficamente é uma cidade pequena, então é uma cidade que convida a caminhar e eu aceito esse convite. A Asa Norte, basicamente, se tivesse que definir com algo seria com natureza, pássaros, insetos, plantas, folhas, cogumelos, isso de verdade me encanta, isso é um luxo em uma cidade, e gente de todo tipo. Tem um preconceito muito generalizado que não, que em Brasília não se pode caminhar, que em Brasília ninguém caminha, e eu tenho constatado que muitos brasilienses caminham em Brasília, mas bastante, não são poucos, sim? Alguns praticando esportes, outros se deslocando simplesmente. Vai caminhando por uma calçada e essa calçada surpreendentemente dá um giro de 90 graus que te tira do seu caminho, há alguns lugares
}

\footnotetext{
76 ibdem

${ }^{77}$ Disponível em: http://www.youtube.com/watch?v=zzY45OCRQag. Acessado em 05/05/2013
} 
bastante transitados onde não tem calçada, mas o cidadão brasiliense já tem construído, já tem falado: não, aqui é para caminhar e se o urbanismo não me oferece essa oportunidade eu a construo, então é normal que você veja este pequenos caminhos que as próprias pessoas constroem (...) Eu acho Brasília muito interessante e uma cidade também bastante complexa, tão particular, o processo de entendê-la não pode ser de um dia para outro, ela precisa de um tempo de digestão." (registro no clipe traços da cidade - youtube - tradução da autora)

O tempo de digestão é o tempo de maturação, proporcionada pela experimentação. É como dizer que Brasília “não é para principiantes (...) é o tubo de ensaio da utopia, você está na utopia e ela não é o normal, não e a normose"

A possibilidade de experimentar a cidade pela caminhada marca inclusive a reconfiguração do desenho da cidade pelo pedestre e foi previsto por Lucio Costa. Comenta ele que

os gramados não contribuem unicamente para a serenidade ambiente, são os tapetes da cidade e como tais devem ser pisados, sempre o entendi assim, quando certas áreas se apresentarem gastas, bastará isolá-las algum tempo e as trilhas eventuais deverão ser mantidas pois indicam a necessidade de um caminho ali (COSTA, 1991).

Essa reconfiguração não está simplesmente relacionada à marca física deixada no espaço, mas na constante reinterpretação do espaço como lugar de inúmeros significados simbólicos. Para um melhor entendimento trazemos a descrição de Careri (2013) sobre a transformação do lugar pela caminhada. Ele explica que essa transformação não é uma "construção física do espaço", ela se qualifica como uma "transformação do lugar e dos seus significados". Se o espaço não mapeado conta com a presença física do homem e suas variadas percepções recebidas ao atravessá-lo, implica na "forma de transformação da paisagem que, embora não deixe sinais tangíveis, modifica culturalmente o significado do espaço e, consequentemente, o espaço em si, transformando-o em lugar. Sendo assim, “o caminhar produz lugares (...), ( e é) uma ação que, simultaneamente, é ato perceptivo e ato criativo, que ao mesmo tempo é leitura e escrita do território".

\footnotetext{
${ }^{78}$ Declaração de Bené Fonteles in "Sob o signo da Poesia” de Neto Borges (2011)
} 
Se esta pesquisa traz a proposta da caminhada para uma maior conscientização do meio e das inter-relações é porque se apóia nas teorias de que no espaço de convivência do homem com o meio, que ele toma consciência de sua real existência e “estudar o espaço vivido significa superar a dimensão do espaço-extensão, ou espaço suporte das atividades, para acolher a noção de representação do espaço, como espaço construído através do olhar das pessoas que o vivem-habitam” (BETTANINI, 1982). O que se tem reforçado até aqui é a necessidade da vivência e da experimentação do homem, para maior compreensão do espaço, "em nome da natureza, em nome da liberdade absoluta, em nome da amplidão, que contrastam com a liberdade e a cultura das cidades - no sentido de considerar o homem como habitante da natureza, ou parte dela, e não um elemento da sociedade" (THOREAU, 2003). Experiências que necessitam da predisposição do olhar - elemento da percepção -, da disponibilidade da contemplação e da crença na possível interação entre homem e natureza que se intensifica com a caminhada. 


\title{
PROJETO BRASÍLIA BUCÓLICA - A EXPERIÊNCIA DO CAMINHAR
}

\author{
Na primavera até o homem parece reviver com a \\ natureza. Da mesma forma como as árvores \\ ostentam seu verdor mais claro, mais vivo e mais \\ fresco que possa existir, o homem também toma \\ consciência de todo o caráter sensível de seu ser (...) \\ nesses dias radiosos em que o ar está totalmente \\ puro e sem o menor vapor, o verde das árvores é \\ mais verde, mais vivo do que de hábito. Parece \\ então resplandecer num elemento mais etéreo. \\ Karl Gottlob Schelle
}

O projeto Brasília Bucólica - a experiência do caminhar ${ }^{79}$ foi uma ação de pesquisa, desenvolvida concomitante a esta investigação. Trata-se de um projeto aprovado pelo Departamento de Extensão da Universidade de Brasília (DEX/UnB) que consiste na proposta de exploração para um novo olhar sobre a cidade de Brasília em suas Escalas Bucólica e Residencial (pertencentes ao Plano Piloto). Dentre as atividades, foi criado um concurso aberto aos alunos da universidade e toda a comunidade, onde foram registradas expressões fotográficas sobre a cidade percebida ao caminhar. Para viabilizar o projeto, contamos com a participação de 15 estudantes de graduação em Turismo da UnB.

Figura 81: Projeto Brasília Bucólica

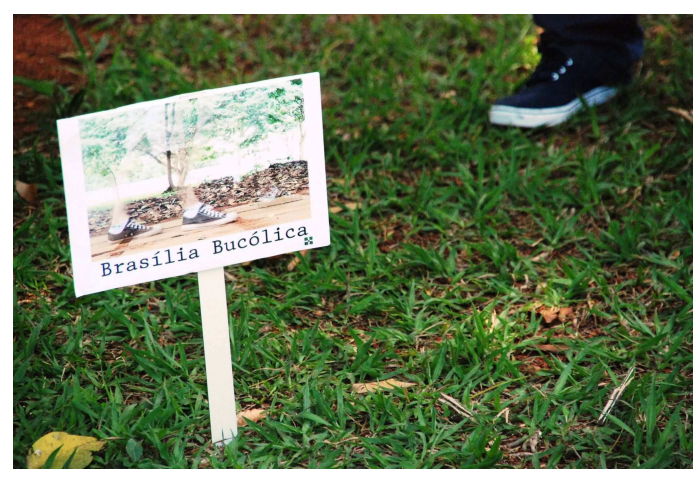

Fonte: Marcelo Moreno

\footnotetext{
${ }^{79}$ Projeto coordenado pela Prof. ${ }^{\text {a }}$ Dr. ${ }^{\text {a }}$ Karina e Silva Dias (CET/UnB) e pela Prof. ${ }^{\text {a }}$ Esp. Tatiana Vieira Terra (SENAC/DF, Mestranda do CET/UnB)
} 


\section{APRESENTAÇÃO DO PROJETO:}

Brasília nasce impregnada de pensamento utópico próprio do movimento moderno em relação à arquitetura e urbanismo. O processo de pensamento e construção da cidade prescinde deste conceito, uma utopia construída, uma cidade habitada. Desde sempre existe uma divisão entre o pensamento abstrato da cidade, advindo das escolas de pensamento internacionais e brasileiras da época, mas também separada da experiência "vulgar" do habitante, conhecedor das escalas mais íntimas e menos monumentais. Uma cidade moderna, dividida e atravessada pela visão simbólica da arquitetura. Aqui, o espaço natural converte-se em natureza construída, uma expansão bucólica no espaço residencial. Os espaços das Entrequadras são a representação mais concreta disto.

A cidade apresenta o espaço bucólico, a princípio relacionado à condição silenciosa da solidão, a quietude da natureza inviolada e os espaços das Entrequadras, como exemplos de lugares de representação de uma nova natureza intrinsecamente ligada à arquitetura, ambas unidas por uma condição abstrata e similar, que permitem a experiência sensível do espaço pelo habitante, pelo planejamento e pensamento do criador.

As áreas verdes das Entrequadras são os lugares mais próximos das próprias residências, dentro do Plano Piloto: são áreas de extensão do lar. Um espaço orgânico e rico, pensado para não ter limites e determinado pela construção de uma arquitetura racional, a utopia construída, nossa capital.

Orgânico, racional e monumental... Qual é a visão das pessoas que habitam Brasília? Os espaços livres de conexão podem ser atravessados normalmente? Quais seus caminhos? É uma cidade viva? Mutante?

Os caminhos criados pelo percurso dos habitantes da cidade subvertem o seu traçado original? Seria uma leitura (e uso) espontânea do espaço planejado, um prolongamento da arquitetura construída? 
Como proporcionar a leitura dos espaços residenciais e suas diferentes escalas? Existe um reconhecimento destes locais de conexão e pertencimento?

Procurar e encontrar os espaços de expansão da escala bucólica de Brasília pode ser determinado pela vivência dos mesmos. Um objeto perdido, um objeto reencontrado. Aqui se estabelece novas relações humanas, e o entendimento do espaço por meio da percepção. Uma geografia humanista traduzida através da experimentação pessoal que conecta afeto e ambiente. Um lugar percorrido a pé.

Para a criação de experiências proporcionadas por percursos a pé o projeto compreendeu propostas de desvelamento do espaço para além do cartão postal: roteiros a pé produzidos por estudantes da UnB. O projeto, que teve a duração de 6 meses, está vinculado às teorias contemporâneas do Turismo e concepções do Turista cidadão.

Como objetivos previstos e alcançados, o projeto promoveu uma nova experiência nas Escalas Bucólica e Residencial de Brasília pelo caminhar do habitante. Promoveu virtualmente a interação entre a universidade e a comunidade por plataforma digital, viabilizando um concurso para aos cidadãos e visitantes da cidade de Brasília, que puderam expor reflexões sobre os espaços da escala bucólica/residencial pela utilização de imagens fotográficas. Realizou uma oficina para estudantes e comunidade durante a Semana Universitária da UnB / 2014, onde também ocorreu a premiação dos vencedores do concurso.

Como metodologia para a execução do Projeto, traçou-se: pesquisa de campo no espaço com estudantes do CET/UnB; criação de imagens e verbetes relacionados à cidade, bem como discussões semanais do tema com os estudantes do curso de Turismo do CET/UnB; criação de um concurso vinculado ao Centro de Excelência em Turismo da Universidade de Brasília e ao decanato de Extensão da mesma Instituição; criação de uma plataforma digital de divulgação das etapas do projeto e inscrição do concurso; divulgação de edital de concurso por meio digital e gráfico, nos espaços de interesse e aberto para a comunidade; recepção dos trabalhos inscritos e catalogação segundo linguagem artística utilizada; escolha da banca examinadora e determinação das regras e modalidade de escolha dos trabalhos; análise e classificação dos trabalhos; busca de apoio para a premiação dos vencedores; piquenique de premiação e divulgação dos 
resultados via plataforma digital e realização de oficina sobre o projeto e seus desdobramentos, com ênfase às novas abordagens do Turismo.

Foi um projeto que envolveu estudantes da graduação do Turismo e outros estudantes universitários que participaram da Semana Universitária bem como a participação da comunidade em diálogo com a produção científica realizada pelo Centro de Turismo da Universidade de Brasília - CET/UnB. O concurso foi focado em vários acontecimentos que misturam criatividade, vivência e percepção do espaço, e sua inovadora compreensão.

\section{REGISTROS DO PROJETO}

1. Foram elaborados pelos alunos pertencentes ao projeto, verbetes sobre o vocabulário da cidade de forma irônica e divertida, intitulada de "Mitos e Verdades" que posteriormente foram transformados em destacáveis para serem disponibilizados no Campus da Universidade. Alguns exemplos:

Figuras 82, 83 e 84: Verbetes - Projeto Brasília Bucólica
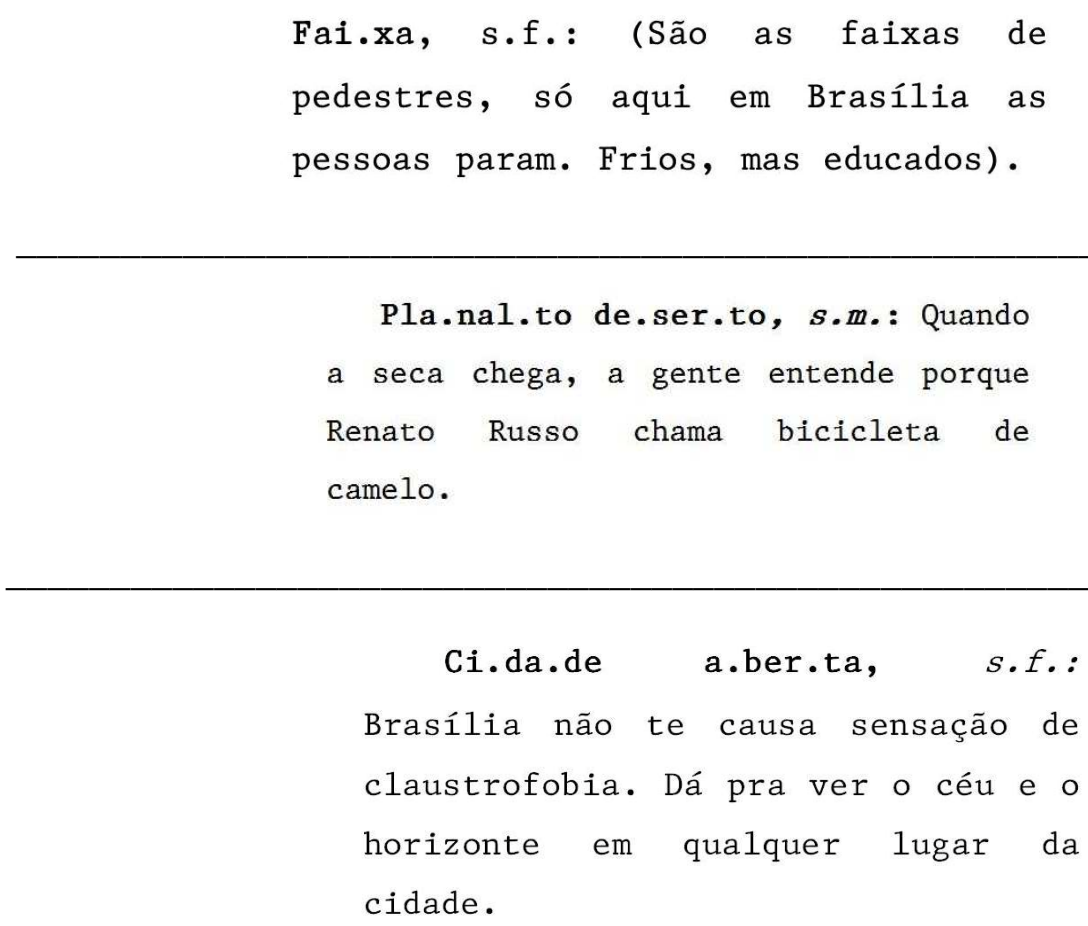

Fonte: https://www.facebook.com/brasiliabucolica (2014) 
Figuras 85, 86, 87, 88 e 89: Verbetes - Projeto Brasília Bucólica

Par.dal, s.m.: Fiscalização eletrônica onipresente. Até hoje não se sabe se o apelido foi dado pela quantidade de pardais (pássaros) presentes na capital ou pela possível habilidade aparente de aparecer em todos os lugares e de procurar abrigo entre as árvores.

Ci.da.de sem es.qui.nas, s.f.: Não mande alguém ver se você esta lá na esquina, porque você pode nunca mais ver essa pessoa.

Ci.da.de da cor.rup.ção, s.f.: Adjetivo referente à presença dos políticos de todo o país que trabalham na capital. Você diz que nossa cidade é de gente corrupta, mas os políticos corruptos vem das suas cidades, meu amor!

Ci.da.de Mo.der.na, s.f.: É uma cinquentona enxuta, toda mal falada.

Bras. (i.1ha), s.f.: 0 pequeno quadrilátero candango pode-se comparar com uma ilha graças ao pequenino tamanho. 
Figura 90: Verbetes - Projeto Brasília Bucólica

\section{BRASÍLIA BUCÓLICA}

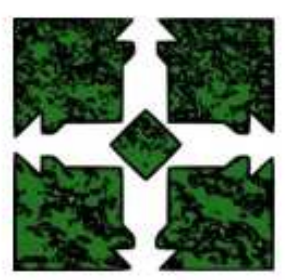

Maís informações:

F/brasiliabucolica

$0^{9} @$ brasiliabucolica www.brasiliabucolica.com.br
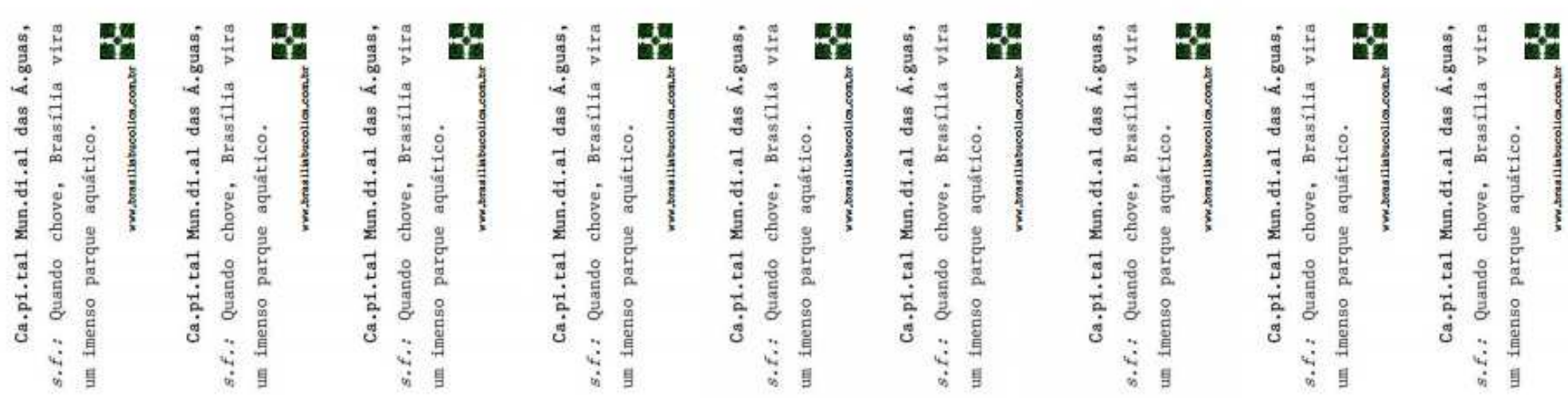

Fonte: https://www.facebook.com/brasiliabucolica (2014) 


\section{BRASÍLIA BUCÓLICA}

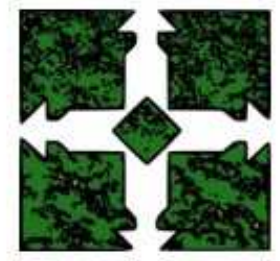

Maís informações:

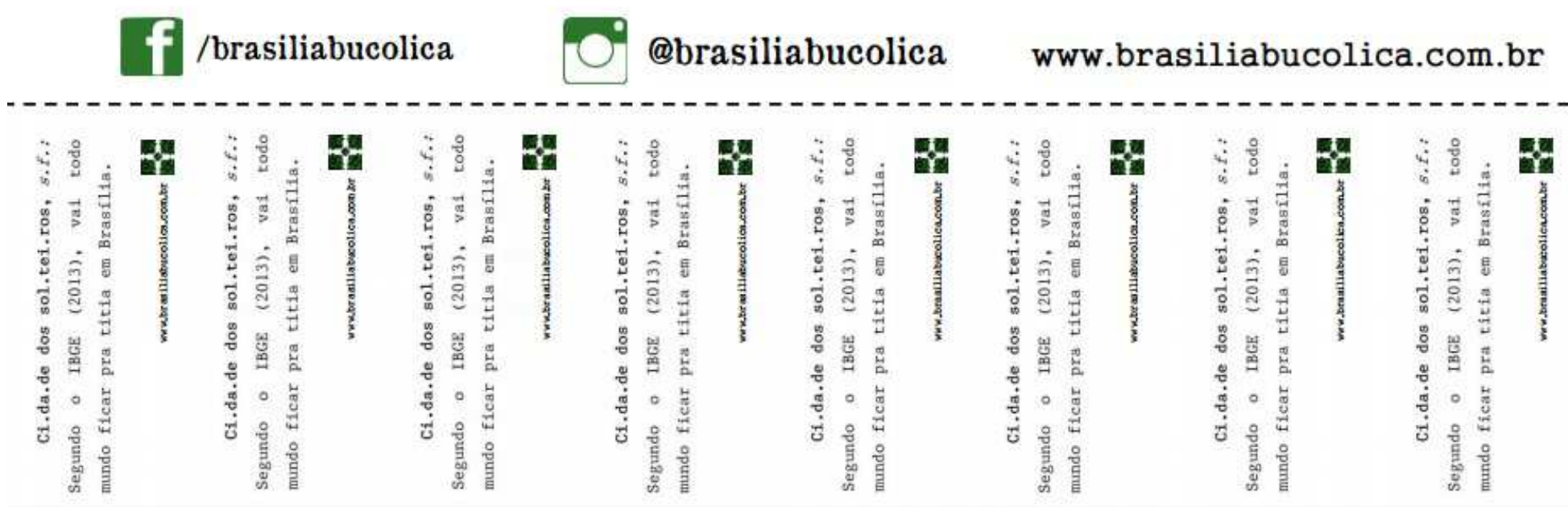

Fonte: https://www.facebook.com/brasiliabucolica (2014) 
2. Todos os integrantes do projeto, alunos do CET, participaram explorando os espaços das Superquadras, deixando seus registros. Abaixo dois exemplos.

A. Registro fotográfico e descrição em escrita poética - Trabalho realizado pela aluna Nayara R. Marques, que após experiência de caminhada em uma Superquadra da Asa Norte, registrou sua impressão de forma estética inspirada em sua experiência prática.

Figura 92 - Registro fotográfico pela experiência do caminhar

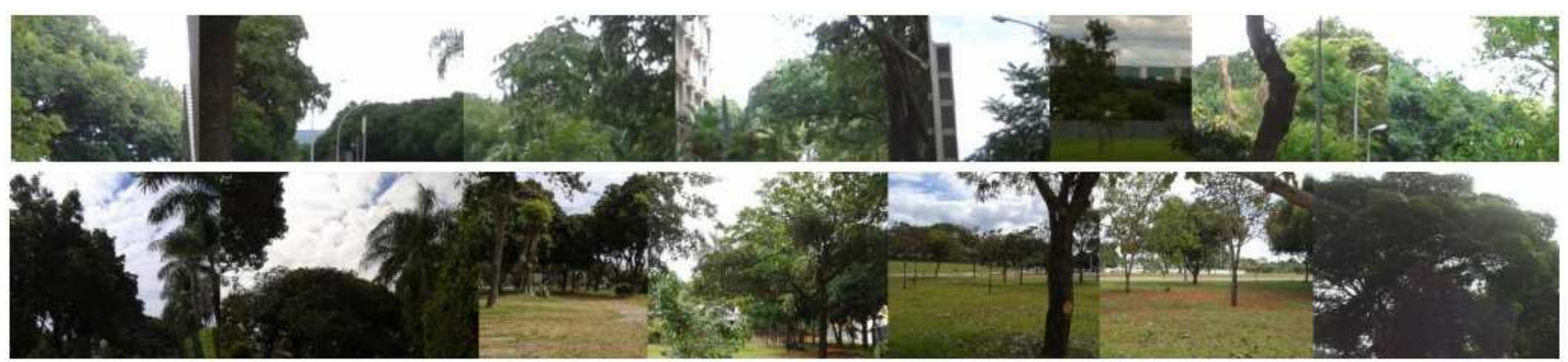

Fonte: Nayara Marques (2014) 
o caminhar, o passear, o contemplar. o caminhar pela cidade, pela calçada, pela rua, por cada passo a passo na medida em que o olhar percorre a e o andar a pé, o olhar... entre quadra, pelas entrelinhas, pela trilha ou pelo asfalto paisagem, o cerrado dentro da cidade.

o céu de Brasilia, que se integra à paisagem, que é colorida com concreto, com os sonhos, com os monumentos da cidade repleta de traços de tantos se entrega ao olhar, que se entrega ao pensamento sons e o silêncio. silêncio verde em contraste com arquitetos em detalhes ao ar livre. sons dos pássaros ou um mundo interior que não se cala nem com chấo: terra-seca. silêncio disputado com os que, esses sim, habitam cada lugar.

a seca, nem com o sol, nem com o calor, nem com automóveis passando na rua que está ali logo atrás

o calo criado de tanto andar por sobre esse châo daquelas árvores... rua ignorada. rua ignorante,

de calçada quebrada misturado com gramineas. espaço feito para as máquinas, não para as escolhas.

oque interrompe, pessoas.

movimento-monotonia

motivo

um anùncio sobre o algo perdido, isso é motivo

a cidade, a quadra, o bloco residencial: isso é lugar para um registro? ou para parar

pra uma enxada? por que a surpresa?

horizont

ou uma experiência

o dominio da natureza

viva.

parte da cidade reconhecida:

corte no espaço

modificado especialmente para o conforto do ser que tem poder

humano

escala

subjetiva

de solidăo

de registro

direito

esquerdo relativizaçāo

Fonte: Nayara Marques (2014) 
B. Registro textual e fotográfico realizado após experiência de caminhada em uma Superquadra pela aluna Evellin Lima, que mora em Ceilândia (RA IX):

Figuras 94 e 95 - Registro fotográfico pela experiência do caminhar
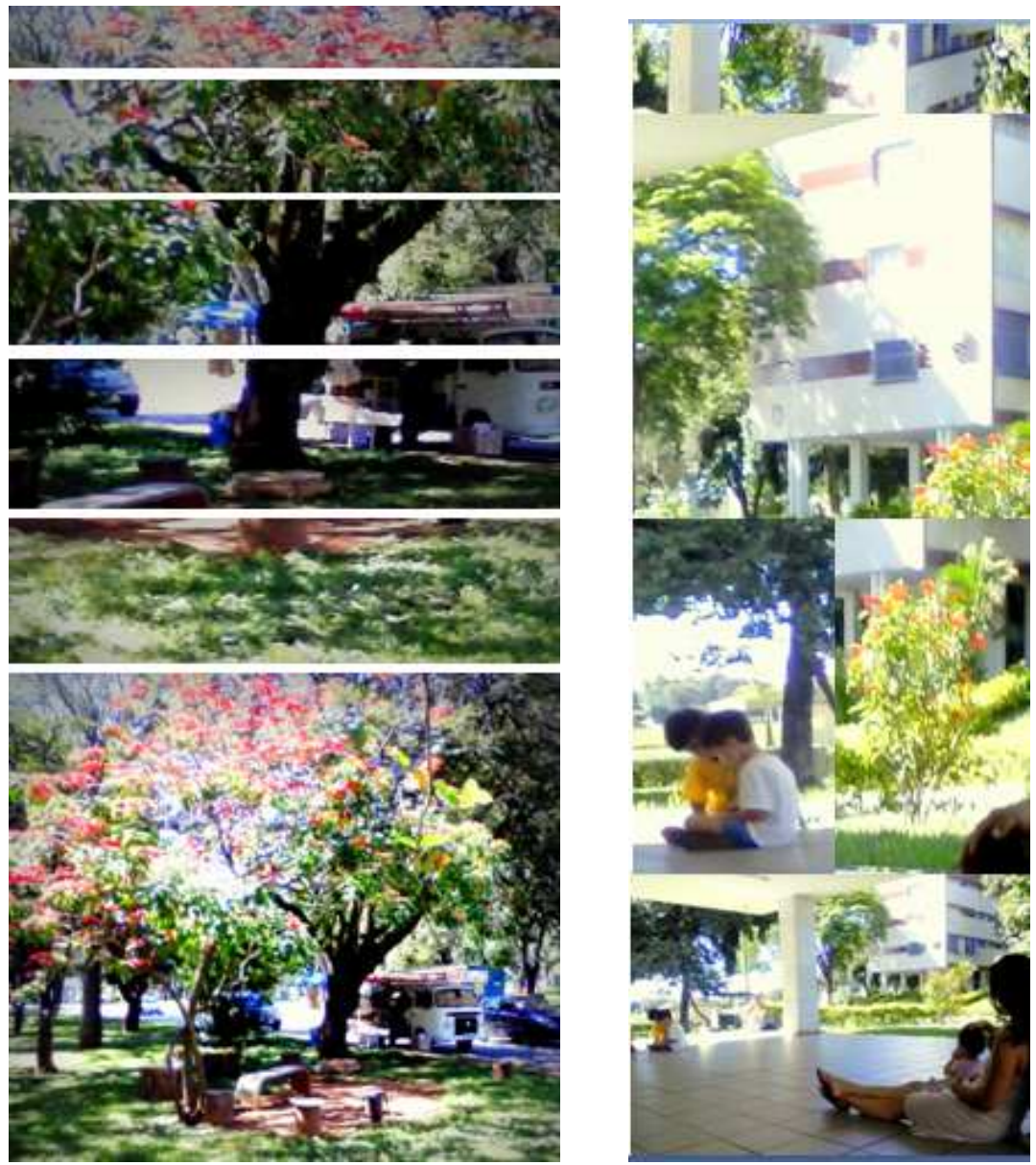

Fonte: Evellin Lima (2014)

“... Tem-se a prática do caminhar, do "andar por andar” que além de ser uma prática estética - pois reordena tudo o que passa pelo nosso olhar - tornou-se uma prática subversiva indo contra o tempo do trabalho e instituindo uma relação individual entre o caminhante e a paisagem. Assim, desconhecendo os espaços da cidade que - apesar de não ser a minha - pertenço, caminhei por quadras que nunca havia caminhado, deparei-me com cenas que não mais se repetirão e cheia de dúvidas, tenho uma única certeza: a de que a pessoa que começa a caminhada, não é a mesma que termina (...) À medida que caminhava, sentia mais ainda a sensação que talvez. Petrarca outrora tivesse sentido, a necessidade de ver o mundo com os próprios olhos. Ainda pisava em lugares que já havia pisado antes, entretanto, me dei certo tipo de liberdade suspensiva, deixando de lado as preocupações do cotidiano e esquecendo todos os demais compromissos, mesmo que por aquele instante (...) Saí de onde meus pés já haviam pisado para dar início a um caminho que me levaria a algum lugar desconhecido (...) Desliguei-me apesar de não estar só e já no início da caminhada notei o quanto a natureza está incorporada no cotidiano, na vida da cidade. Cenas comuns se tornam especiais aos olhos de quem presencia realidades tão destorcidas de suas idealizações (...) Inúmeras sensações me invadiram. Primeiro, a surpresa de ver que crianças ainda brincam, de modo inocente, sem aparelhos eletrônicos, sem próteses. Só brincam . E depois, a felicidade de captar, de presenciar algo tão belo, em que se misturam o humano, o concreto e o verde de maneira tão suave, tão leve .... A medida da experiência é a medida dos pés (...). Sorte daqueles que têm esse imenso jardim como quintal (....) Percebi que nesse momento eu começava a possuir a paisagem e a medi-la pelos meus sentidos. As cores que absorvia, o som dos pássaros se mesclando ao som dos carros passando, o cheiro das plantas ... Quanto a minha companhia? 
Compartilhamos docilmente os passos (...) Já quase no fim do percurso me deparei com a cena que certamente jamais presenciarei de novo, ou não com tamanha profundidade. $O$ encontro entre infância e velhice, a beleza entre essas fases da vida. Este momento me trouxe reflexões. A criança ainda não descobriu seus pés, onde eles podem levá-lo e o idoso, talvez o tenha feito. Talvez tenha experimentado o mundo, ou o esteja descobrindo pelos pés daquele que o conduz. Consegui estabelecer uma relação com o espaço. $O$ absorvi e fui por ele absorvida. A sensação de imensidão invade, preenche. Pude perceber que o homem necessita deste mundo do lado de fora para descobrir o seu mundo interior. 'Ao andar, escapa-se à própria ideia de identidade, à tentação de ser alguém, ter um nome, uma história' (GROS, 2010), esquece-se tudo, mesmo que por poucos passos, pequenos instantes (...) e como quem quer descansar o olhar, inclinei-me para o alto. O céu fez com que eu perdesse a sensação de desconhecido, pois o reconheço. Nele me reconheço. Uma nova sensação tomou conta de mim, a de ter a certeza de ter feito o certo mesmo sem saber. Na caminhada a gente não se engana, pois nossos pés nunca mentem."

Figuras 96, 97 e 98 - Registro fotográfico pela experiência do caminhar
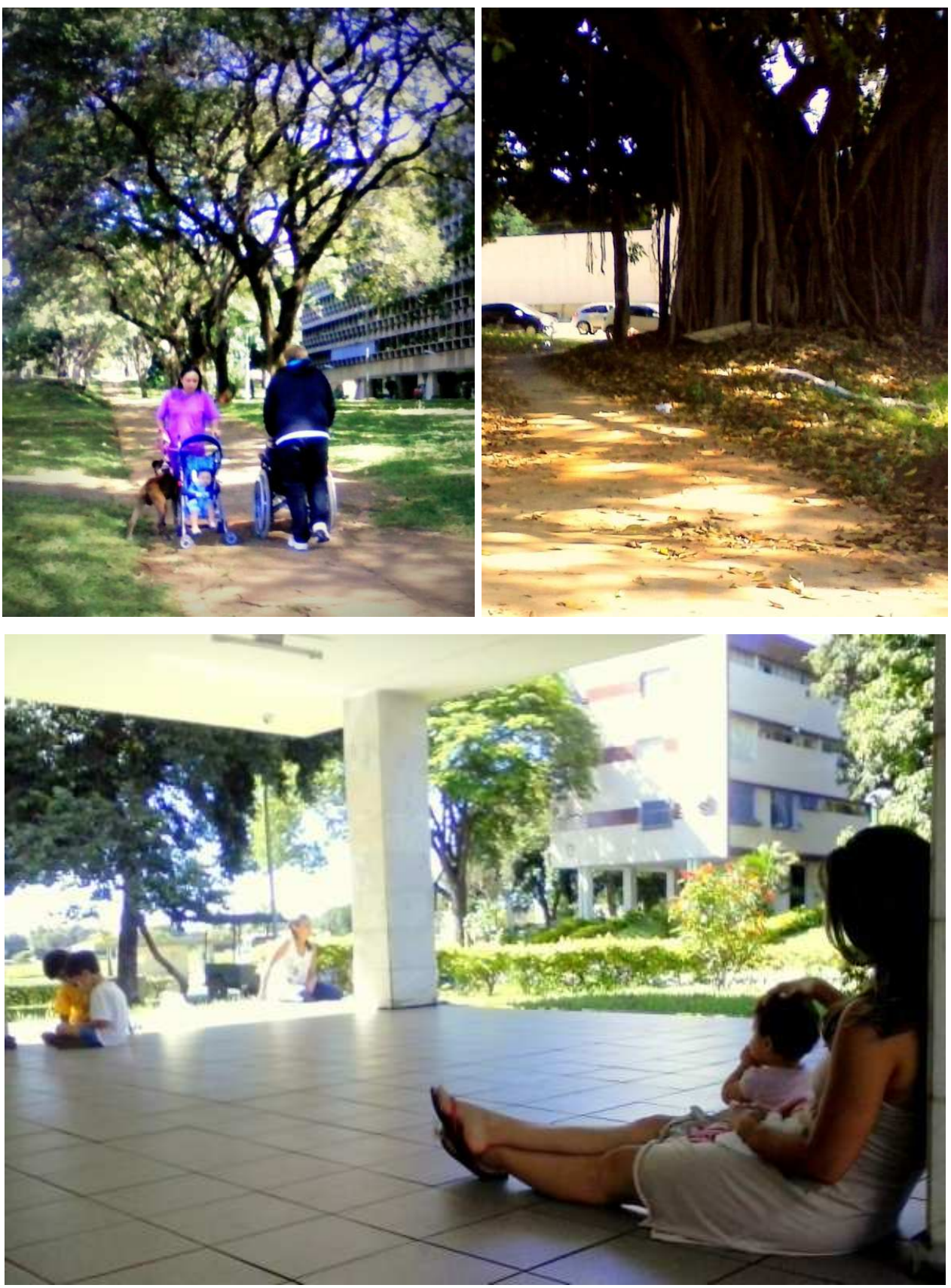

Fonte: Evellin Lima (2014) 
3. Plataforma de interação social:

Com a criação de um perfil do Projeto no Facebook, participantes e seguidores deixavam registros e percepções dos espaços visitados. Foram seis meses de Projeto e ao final contamos com mais de 500 seguidores.

Figura 99 - Projeto na internet

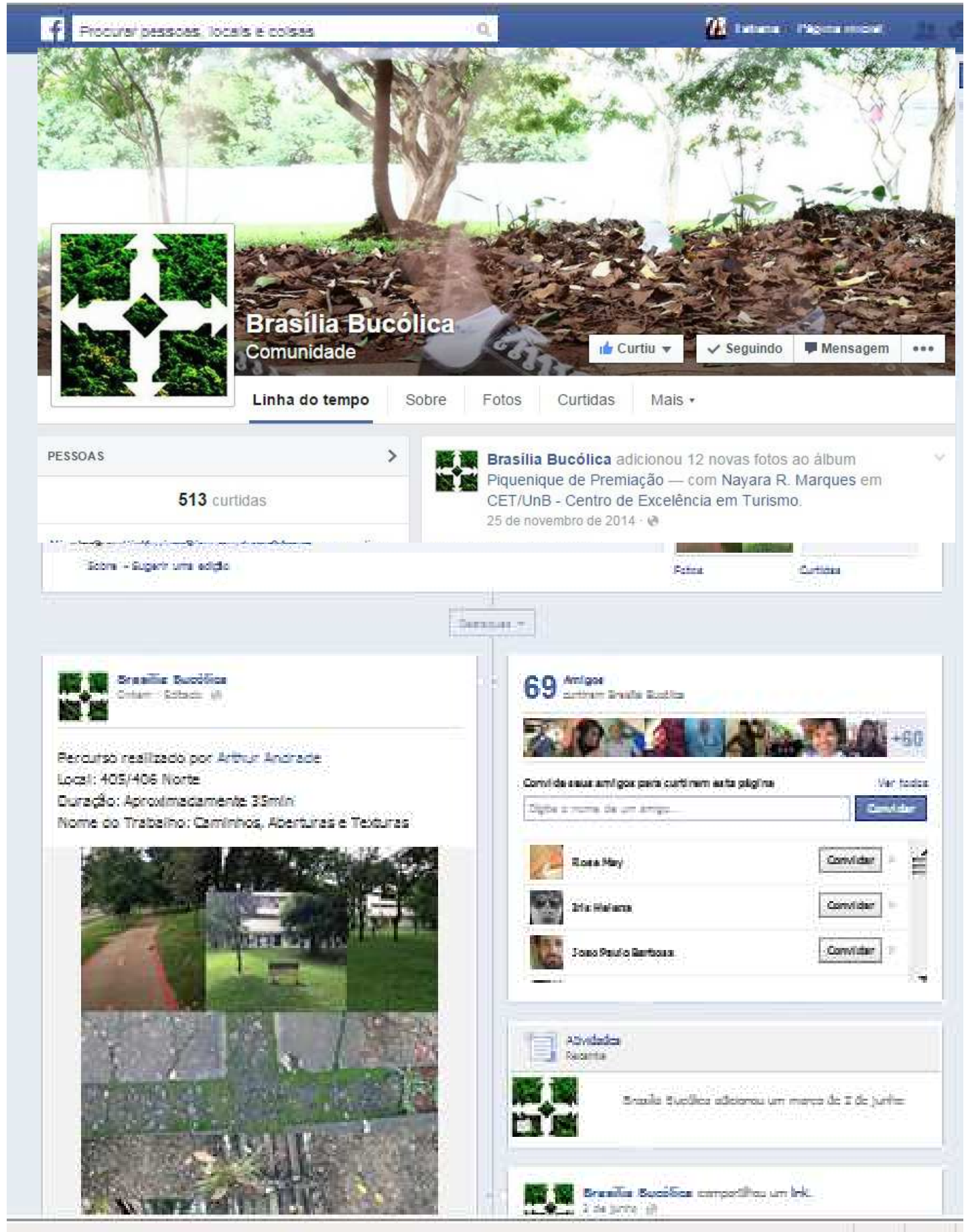

1. Fonte: https://www.facebook.com/brasiliabucolica (2014) 
2. Cartaz de divulgação do Concurso

Figura 100 - Cartaz de Divulgação do Concurso Brasília Bucólica

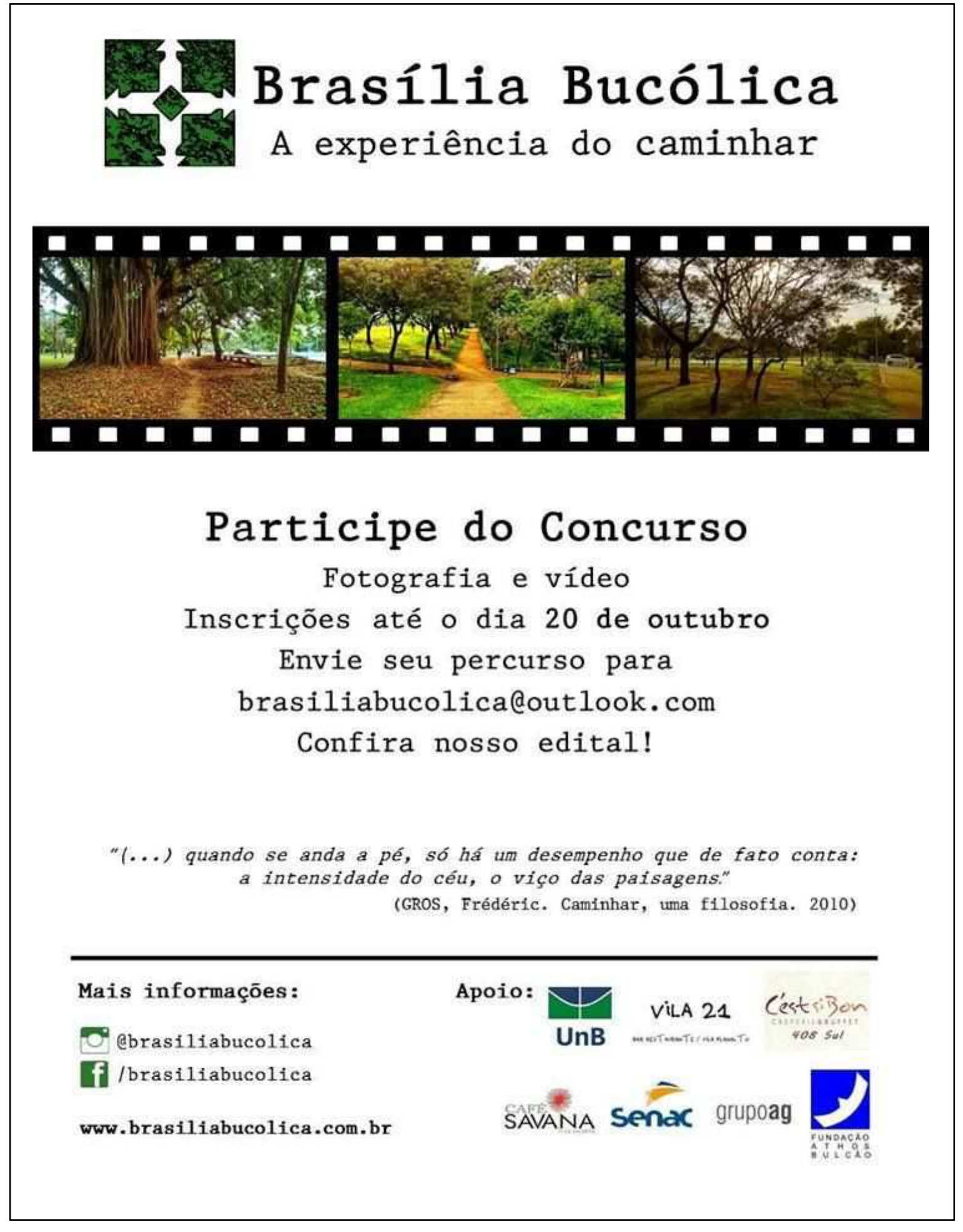

Fonte: Tatiana Terra (2014) 
4. Imagens premiadas do concurso:

$1^{\circ}$ Lugar - Keisuke Yoshimura:

Figura 101 - Imagens ganhadoras do primeiro lugar - Concurso Brasília Bucólica

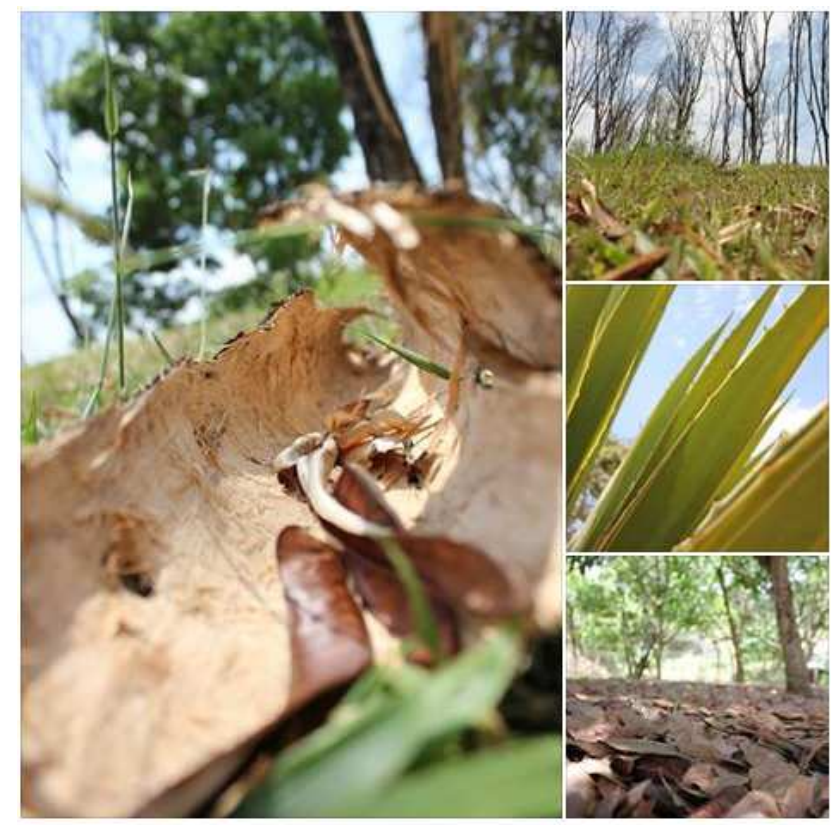

Fonte: https://www.facebook.com/brasiliabucolica (2014)

$2^{\circ}$ Lugar - Pedro Victor Sousa:

Figura 102 - Imagens ganhadoras do segundo lugar - Concurso Brasília Bucólica

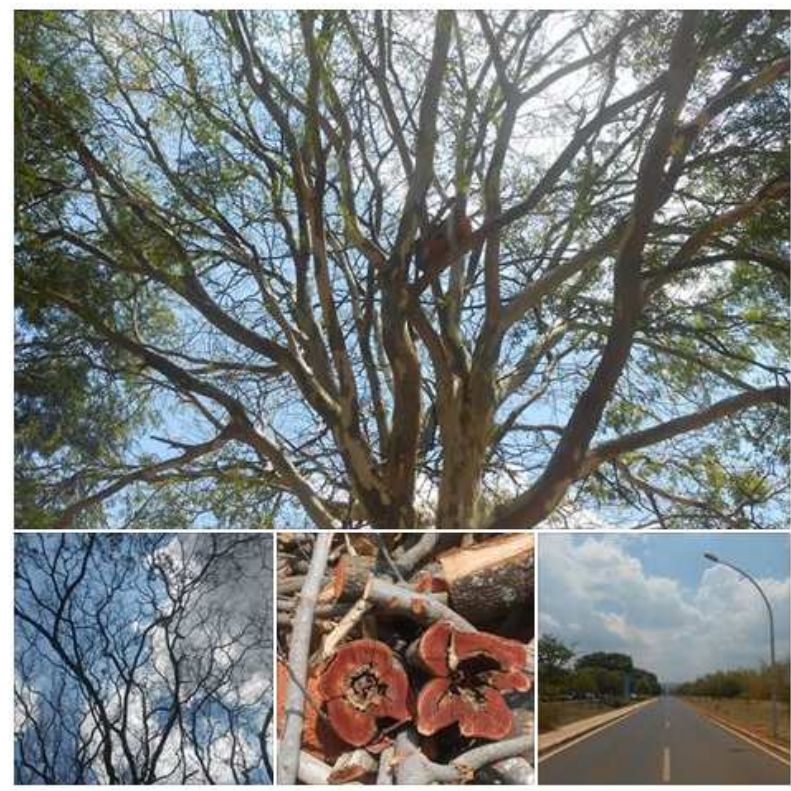

Fonte: https://www.facebook.com/brasiliabucolica (2014) 
$3^{\circ}$ Lugar - Suely Rodrigues:

Figura 103 - Imagens ganhadoras do terceiro lugar - Concurso Brasília Bucólica

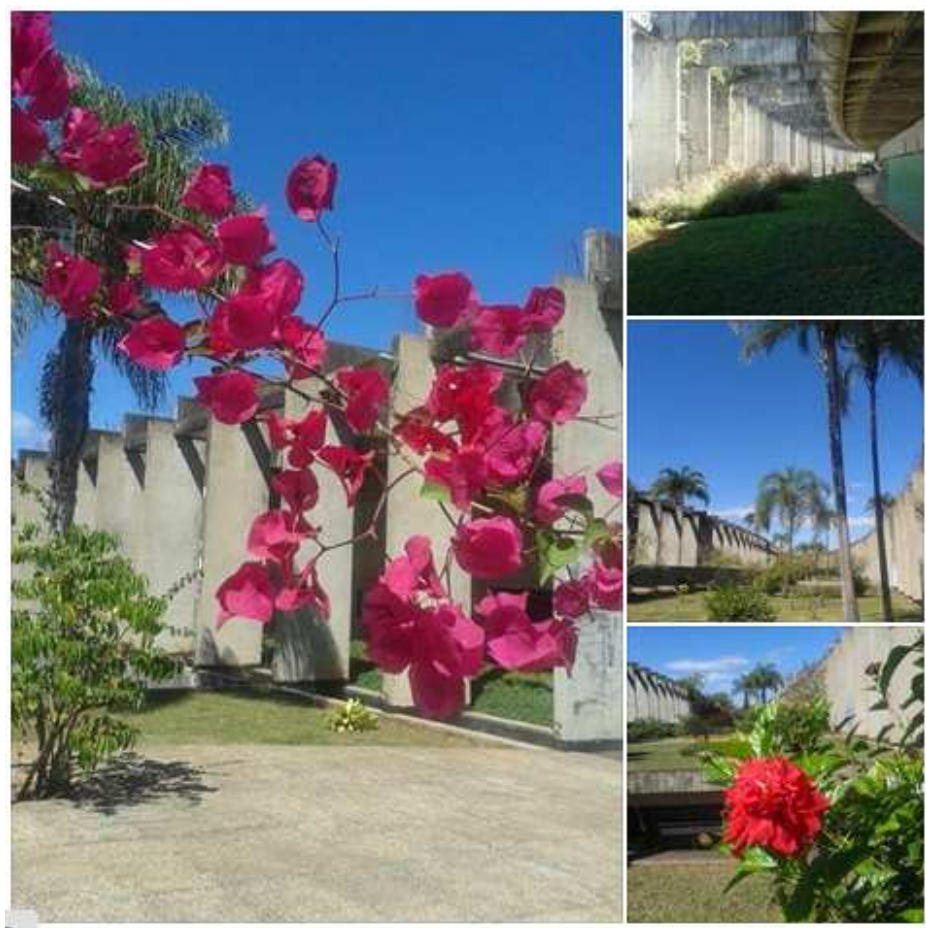

Fonte: https://www.facebook.com/brasiliabucolica (2014)

Prêmio de Menção Honrosa - Cássio Rodrigues:

Figura 104 - Imagens ganhadoras de menção honrosa - Concurso Brasília Bucólica
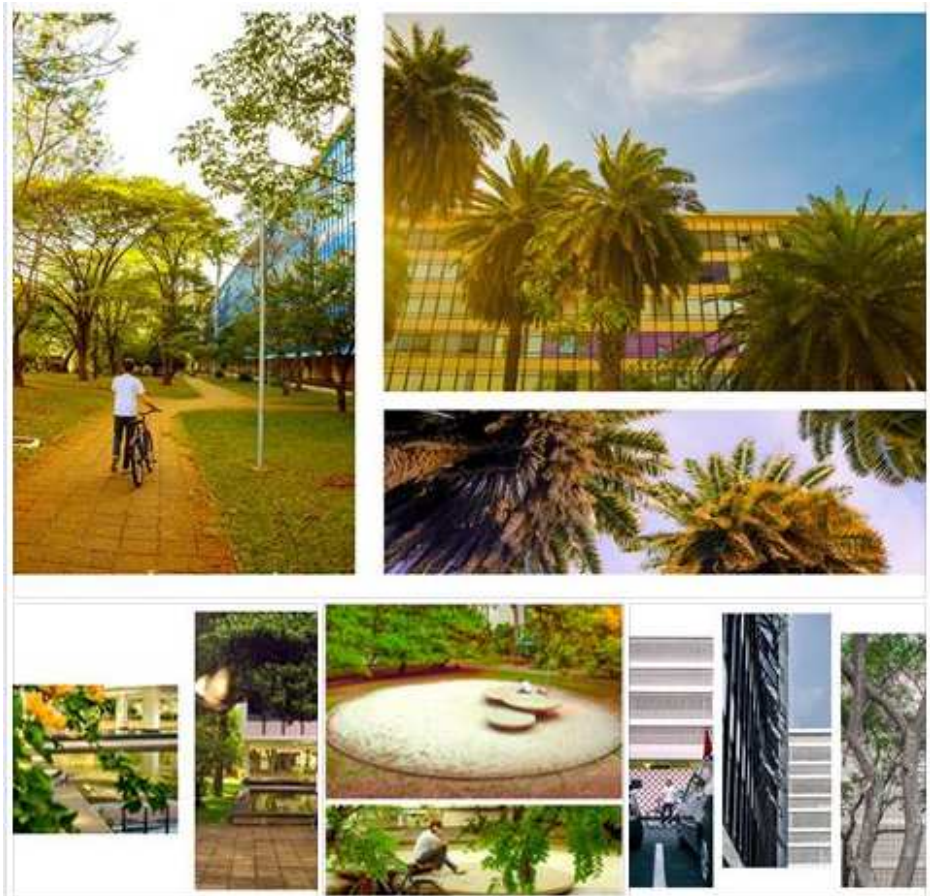

Fonte: https://www.facebook.com/brasiliabucolica (2014) 
5. Premiação:

Realizada no dia 07 de novembro de 2014 no Centro de Excelência em Turismo $-\mathrm{CET} / \mathrm{UnB}$

Figura 105 - Convite para a premiação - Concurso Brasília Bucólica

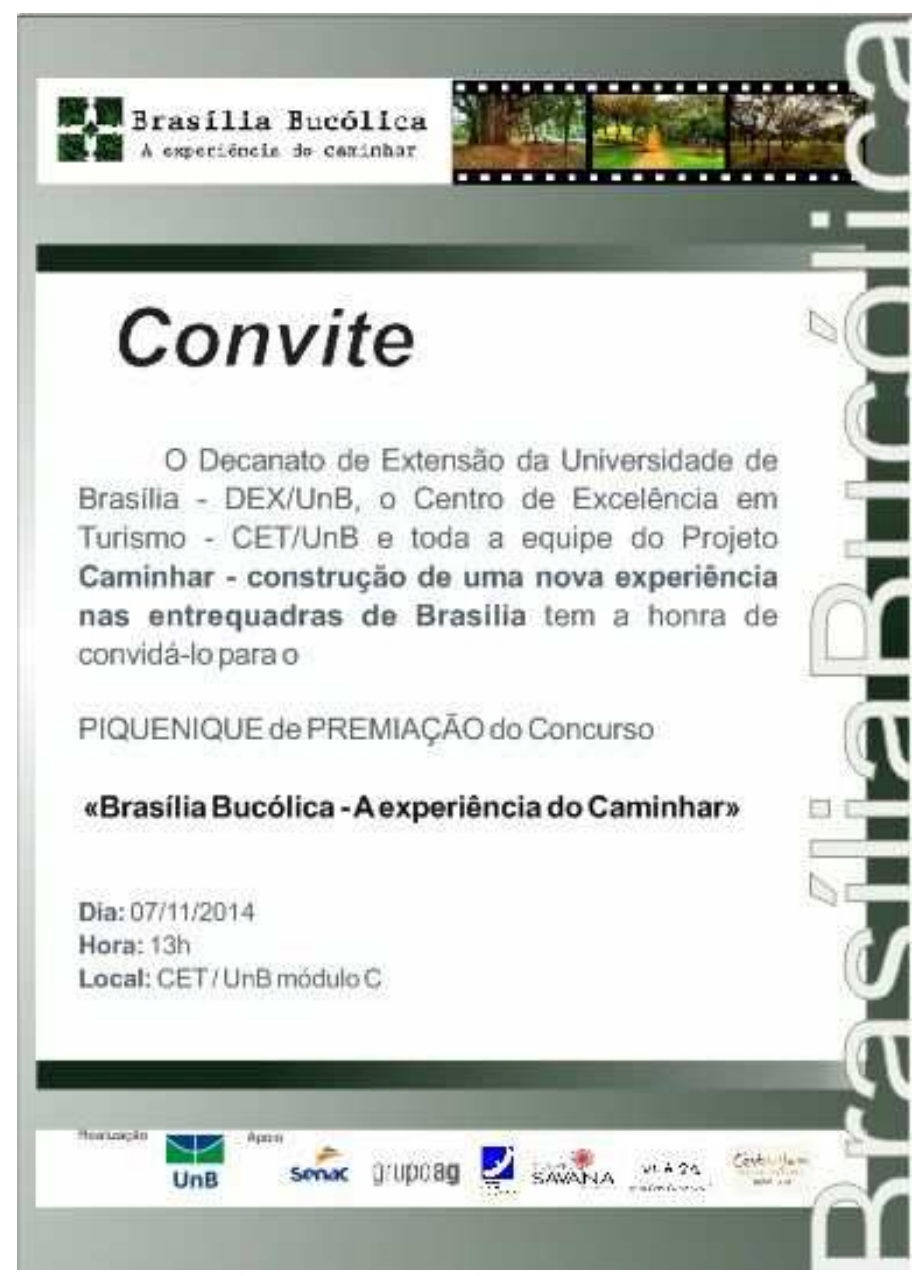

Fonte: Tatiana Terra (2014)

Figuras 106 e 107 - Premiação do Concurso no Centro de Excelência em Turismo - UnB
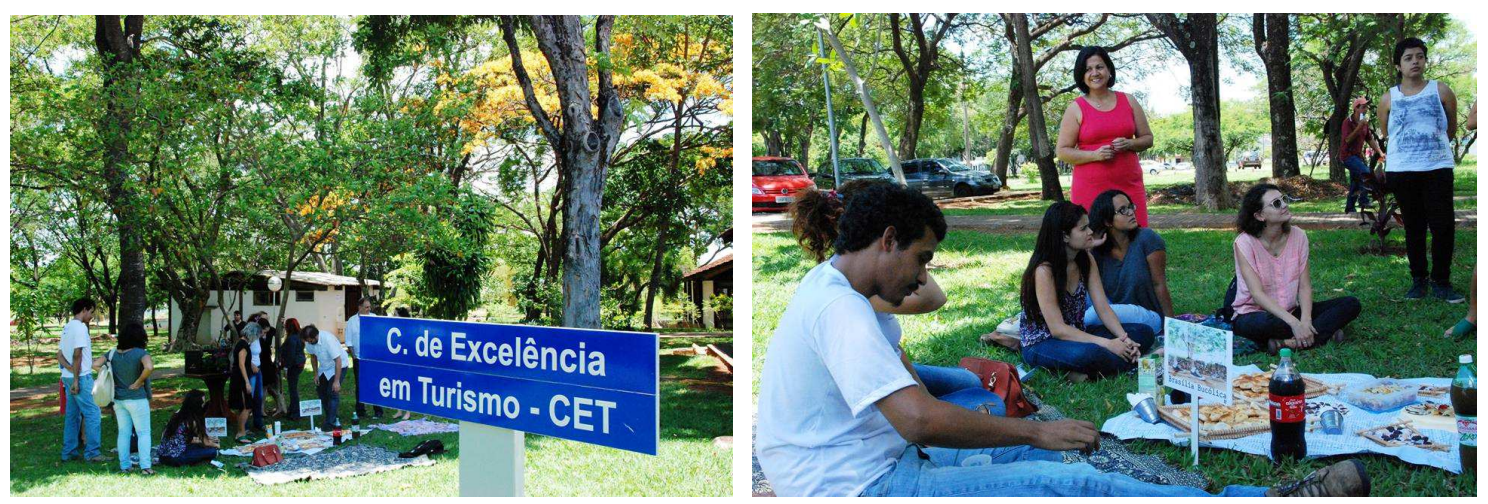

Fonte: Marcelo Moreno (2014) 
Figuras 108 e 109 - Pedro Victor Sousa com Tatiana Terra e Prof ${ }^{\mathrm{a}}$ Dr $^{\mathrm{a}}$ Karina Dias e premiados
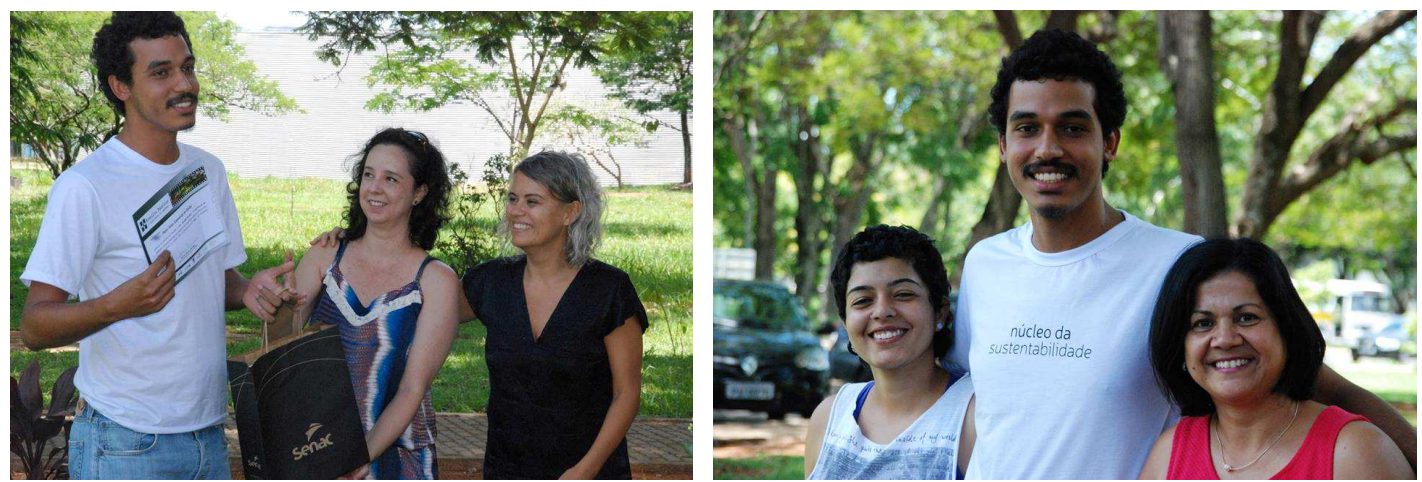

Fonte: Marcelo Moreno (2014)

Figuras 110 e 111 - Prof $^{a}$ Dr $^{a}$ Marutschka Martini Moesch e Prof ${ }^{a}$ Dr $^{a}$ Maria Elenita Menezes Nascimento / Prof. Dr. Luis Carlos Spiller Pena e Prof. Dr. Mozart Fazito
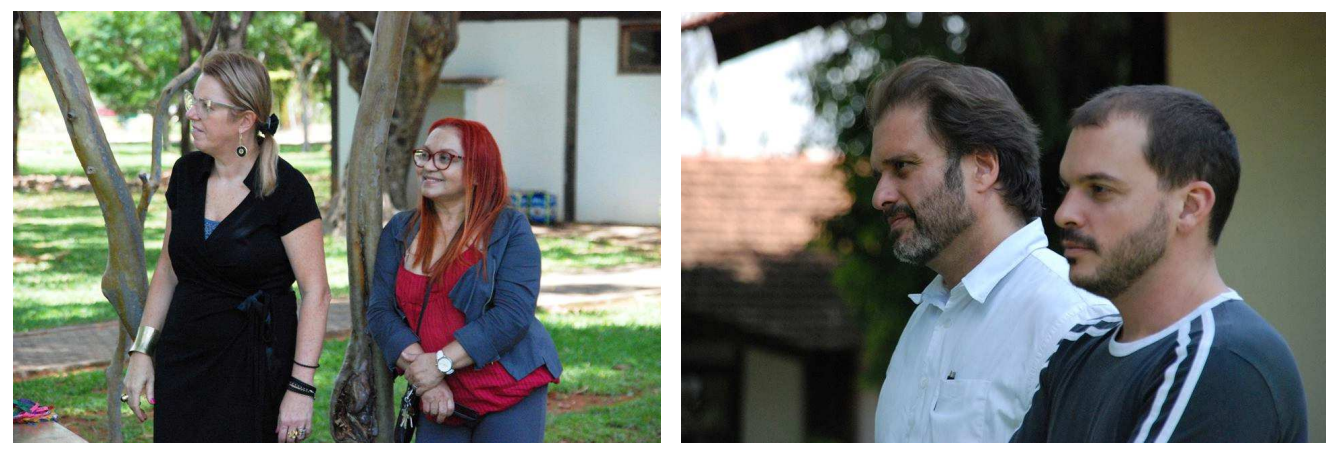

Fonte: Marcelo Moreno (2014)

Figuras 112 e 103- Prof $^{a}$ Dr $^{\mathrm{a}}$ Karina Dias e Tatiana Terra e alunos e professores do CET/ UnB
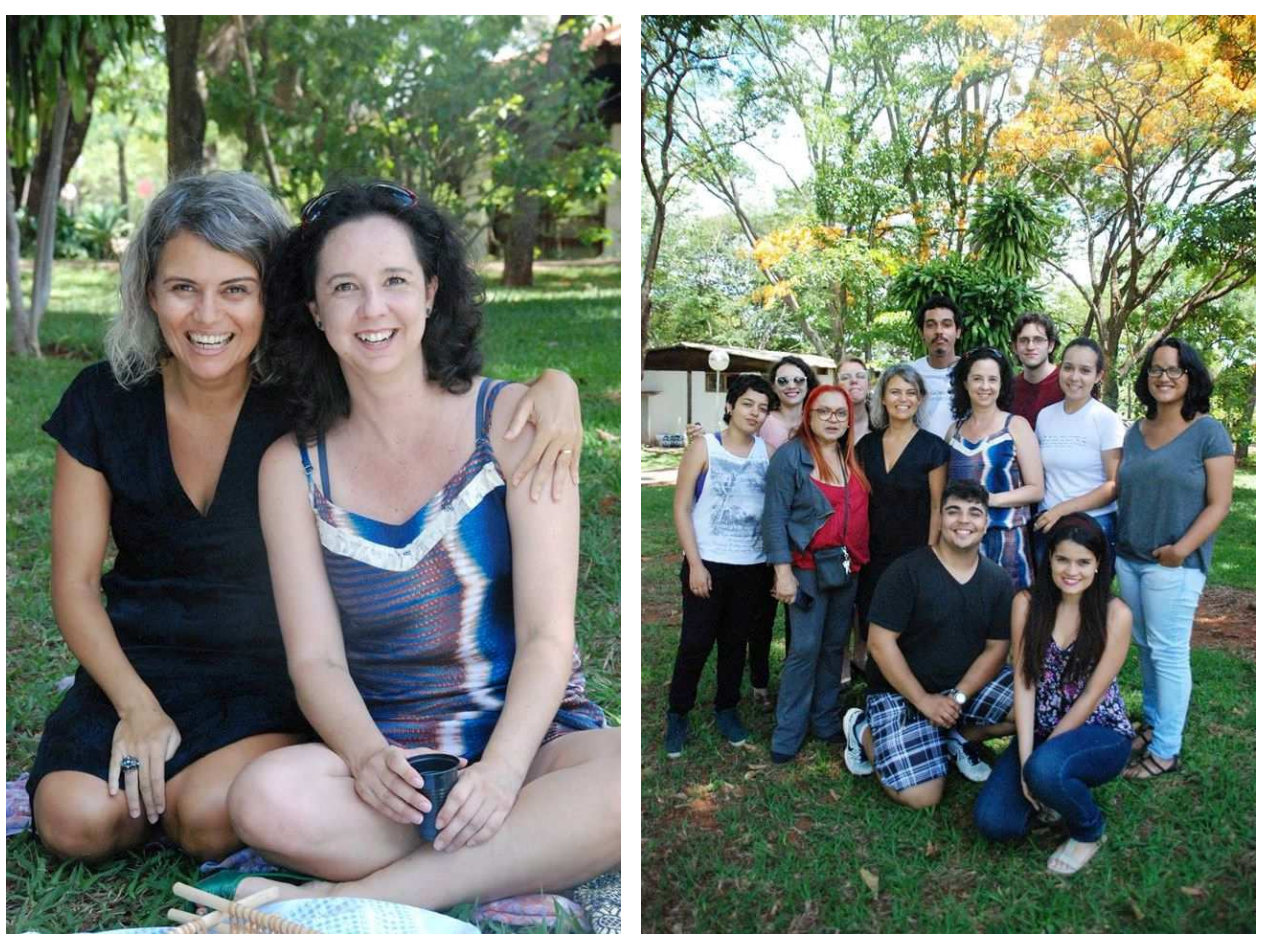

Fonte: Marcelo Moreno (2014) 
O Projeto Brasília Bucólica é resposta prática à teoria investigada. Os participantes apresentaram outras percepções da cidade relacionada à própria experiência de investigação do espaço quando a cidade é explorada para além da arquitetura física, "na arquitetura simbólica", pois é

\begin{abstract}
na ausência de pontos de referência estáveis, cria-se a capacidade de construir um mapa próprio, a cada instante, onde 'a geografia está em constante mutação, deforma-se no tempo com base no deslocar-se do observador e no perpétuo transformar do território'. (...) o percurso é um espaço anterior ao espaço arquitetônico, um espaço imaterial, com significados simbólicos (CARERI,2013).
\end{abstract}

O projeto como aplicação da pesquisa, trouxe-nos a oportunidade de trabalhar as teorias relacionadas ao espaço da cidade de Brasília, a percepção e aprimoramento do olhar nas Escalas Residencial e Bucólica com os alunos de graduação do CET/ UnB durante os encontros para realização das atividades.

Os verbetes produzidos sobre a cidade são reflexo da cidade além do planejado, quando esta se torna realidade que supera o sonho, como na fala de Lucio Costa. É a expressão escrita que designa, renomeia e qualifica a cidade para além do determinado - pela vivencia espacial. A cidade ganha novos conceitos quando observada e vivenciada, como novas características presentes no dicionário da cidade.

Figura 114 - Verbete Pardal

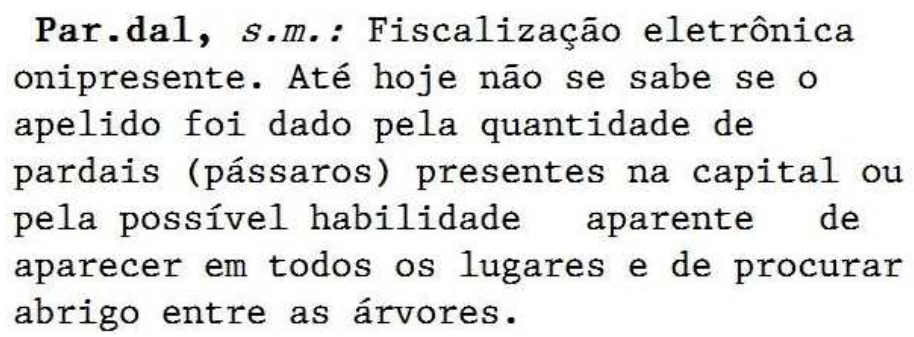

Fonte: https://www.facebook.com/brasiliabucolica

O espaço aberto, os vazios, a arquitetura diluída estão presentes nas formas dos trabalhos apresentados, como é o caso das imagens da aluna Nayara Marques. Em suas imagens observamos o enquadramento do olhar, os recortes da paisagem, as visões distanciadas. Leituras possíveis de um espaço amplo e vasto que disponibiliza o 
horizonte e a vista do céu, uma interpretação possível pelo tempo do olhar presente, que é característica do caminhar.

Figura 115 - Interpretação da cidade
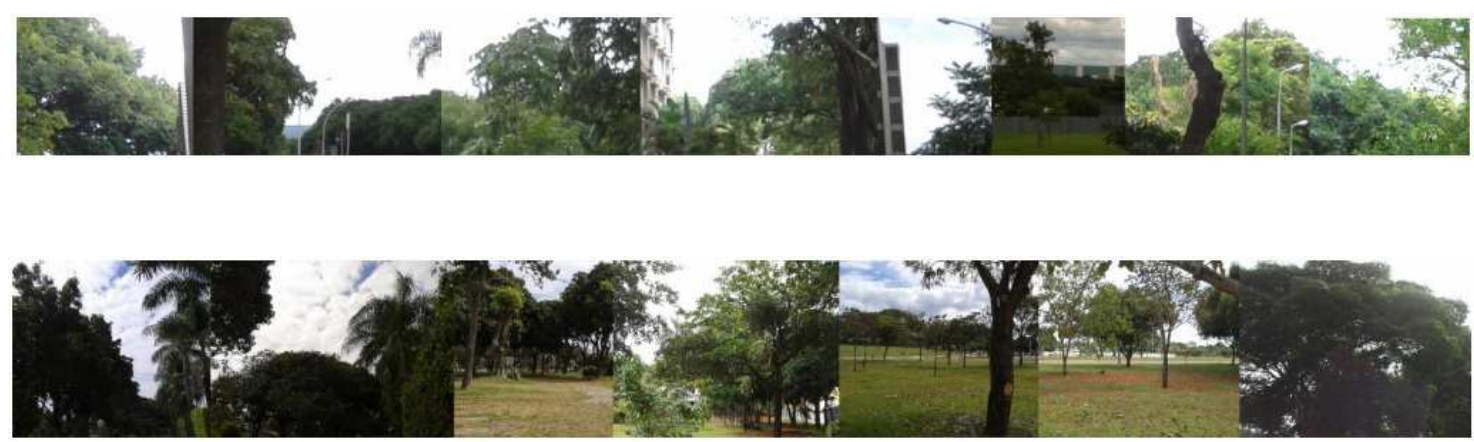

Fonte: Nayara Marques (2014)

As imagens e a construção textual referem-se à própria cidade quando este é exemplo de construção poética que formata em palavras adquire um desenho arquitetado, de espaços e vazios que são pausas e reflexão. Os espaços da cidade, livres, amplos e passíveis de preenchimento, físicos e mentais, foram transpostos na construção da escrita sobre a cidade.

Figura 116 - Interpretação da cidade

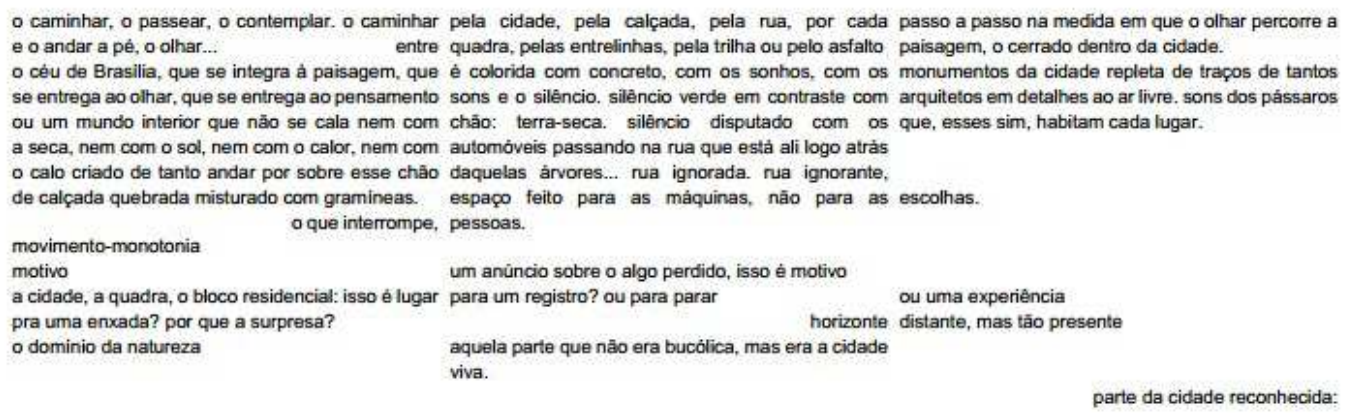

parte da cidade reconhecida:

corte no espaço

modificado especialmente para o conforto do ser que tem poder humano

escala

subjetiva

de registro 
Perceber a cidade nos detalhes só é possível quando se dá a apropriação do espaço pelo corpo, pelo olhar atento, pelo tempo desacelerado proporcionado pela caminhada quando se acalma a mente e se abre a inúmeras sensações. No relato da aluna Évellin, podemos pincelar trechos que falam da liberdade suspensiva ("deixando de lado as preocupações do cotidiano e esquecendo todos os demais compromissos, mesmo que por aquele instante"), das ressignificações do que é aberto, mutável e vivo, características próprias da cidade ("um caminho que me levaria a algum lugar desconhecido"), da descoberta da paisagem pelas sensações adquiridas pelo tempo desacelerado da caminhada ("Cenas comuns se tornam especiais (...) As cores que absorvia, o som dos pássaros se mesclando ao som dos carros passando, o cheiro das plantas ... as sensações” ), do espanto, da surpresa e do maravilhar-se quando o corpo se mescla ao espaço e a paisagem invade ("Inúmeras sensações me invadiram (...) surpresa (...) tão suave, tão leve.... possuir a paisagem e a medi-la pelos meus sentidos (...) sensação de imensidão (...) Momento de reflexões....mundo interior"). Da experiência do percurso produzido pelo tempo do caminhante quando o espaço traz sensações de pertencimento ("o céu... nele me reconheço).

Figura 117 - Interpretação da cidade

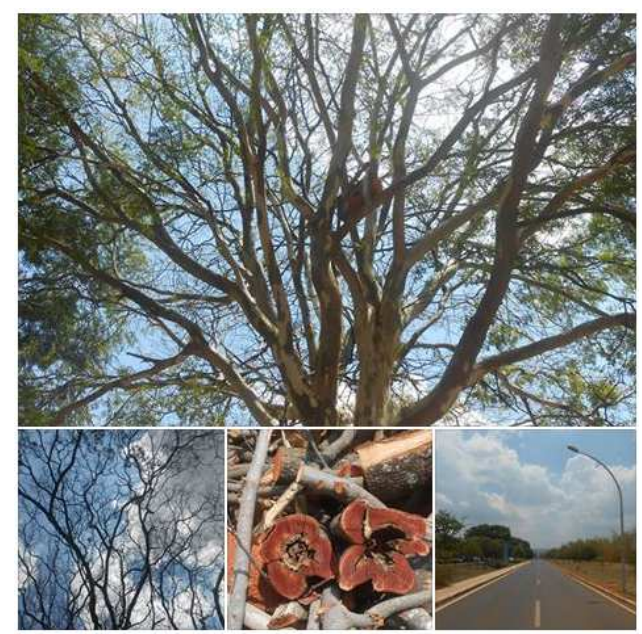

Fonte: https://www.facebook.com/brasiliabucolica (2014)

A amplitude dos espaços da cidade também esteve presente nas imagens premiadas do concurso, que revelam também, o olhar apurado pelos detalhes apresentados, o reconhecimento da unidade da cidade transposta nos espaços da Universidade, com seus concretos, sua linearidade, seus jardins . 
Figura 118 - Interpretação da cidade

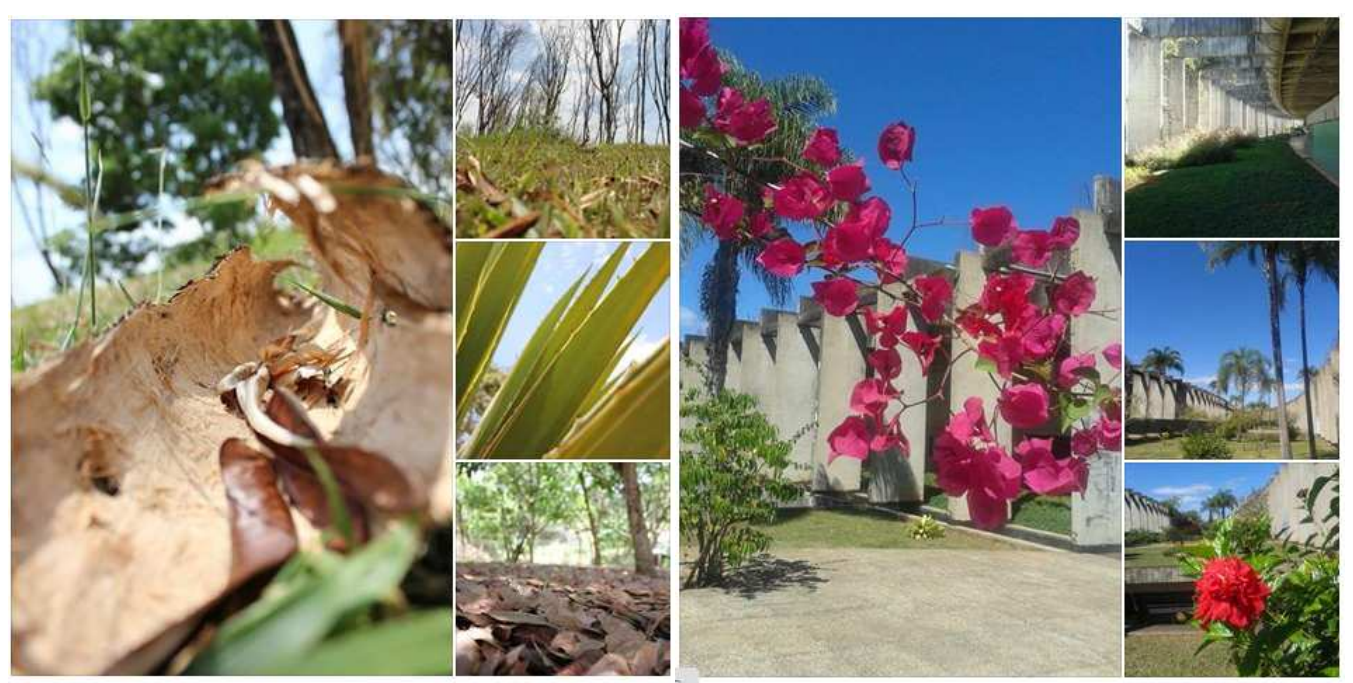

Fonte: https://www.facebook.com/brasiliabucolica (2014)

Aspectos relacionados à própria arquitetura de Brasília que permeada pela natureza, integra o campo na cidade pelos aspectos bucólicos presentes em áreas de residencias.

Figura 119 - Interpretação da cidade
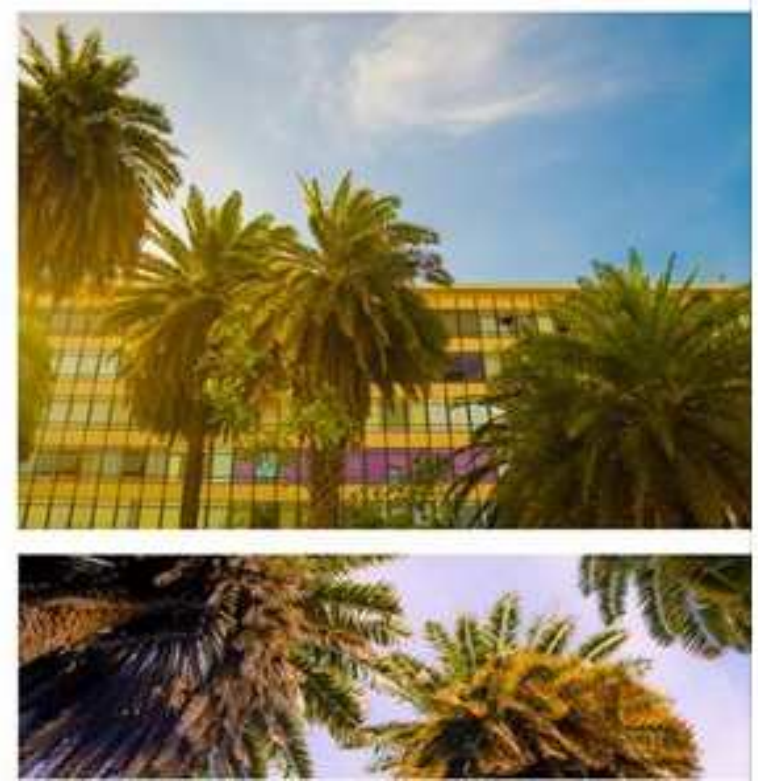

https://www.facebook.com/brasiliabucolica

Assim, o projeto explorou a interpretação da cidade pelo viés de quem a percorre com o olhar atento e com o corpo presente. Características próprias de quem se disponibiliza a percorrer a cidade, começando com « um pé na frente do outro ». 


\section{IV - EM TRÂNSITO}

Esta investigação teve inspiração inicial nos caminhantes Rousseau, Rimbaud, Nietzsche e Schelle, este último pelos seus relatos sobre suas percepções quando caminhava em contato com a natureza - interação por ele definida como um dos prazeres mais nobres que um homem pode ter. A prática da caminhada, registrada na literatura, está associada a uma aguda percepção do espaço percorrido, e quando transpomos para o turismo, traz a oportunidade de uma nova possibilidade de visita e uma nova forma e perspectiva de conhecimento de uma localidade: explorar com olhar atento, ver a localidade em sua essência. Isso porque, diante da aceleração de tudo e dos modos de ver, absorver, apresentar e vivenciar um ambiente, o homem se encontra condicionado a um tempo veloz e pré-determinado. Assim, tem-se a permanência cronometrada nos lugares de visitas turísticas onde muitas vezes, nem ao menos se desce de um ônibus, pacotes turísticos que oferecem cinco países em 20 dias e roteiros prontos e enquadrados com ofertas de visitas em pontos turísticos que são "conhecidos" imageticamente pelo visitante. Uma forma de apresentação do espaço que direciona o olhar, sem a possibilidade de interação.

Em "Morte e Vida das Grandes Cidades" de Jane Jacobs (2011), logo em suas primeiras páginas a autora adverte: Todas as cenas que ilustram este livro nos dizem respeito. Para ilustrações, por favor observe atentamente as cidades reais. Ao fazer isso, escute, concentre-se e reflita sobre o que está vendo. Atravessar um local sem ouvi-lo, sem saborear suas cores, seus cheiros, suas formas, seus detalhes, pode ser como vê-lo pelas páginas de um livro, seu corpo está lá, mas isso não necessariamente significa que você também esteja. Quando uma visita é direcionada - por um guia, por um roteiro determinado, por um mapa - onde o visitante é levado a cumprir a rota estabelecida, é como afirmar que o contador de uma história é o dono dela, quando na verdade, ela é realidade diversa de quem a escuta. "Quem comanda a narração não é a voz: é o ouvido" (CALVINO, 1990). Assim, uma localidade apresenta inúmeras leituras e não pode ser identificada somente por imagens fixas, pelo olhar do outro, sem que o sujeito da experiência interaja com o ambiente/cidade. Uma cidade não é imutável, mas torna-se refém de um caráter restritivo onde “o econômico prevalece sobre o político, o 
vivencial e sobre o simbólico" (LIMEIRA,2006). Ela enquanto localidade é fluxo e passível de encontro das qualidades humanas necessárias para a descoberta do espaço e suas características. Desacelerar para possibilitar este encontro é a sugestão da caminhada, começando com um pé na frente do outro, simplesmente. O caminhar é o movimento de desaceleração do observador, um convite à desconexão momentânea que proporciona o contato com os espaços pelas sensações. Entendida como um estímulo à percepção, a caminhada se apresenta como mergulho em possibilidades infinitas, como em um jogo lúdico que desvela novas formas de habitar pensamentos e ações, na construção de uma outra arquitetura, a arquitetura simbólica da paisagem. A paisagem por sua vez, redesenhada pelo diálogo estabelecido pelo caminhante é entendida por suas referências qualitativas. Um outro modo de olhar a paisagem implica um outro olhar sobre o mundo. A paisagem de Brasília modificada pela caminhada em seus espaços propícios contribui inclusive para um novo olhar sobre a cidade, "capaz de captar não apenas suas dimensões objetivas - estrutural, funcional, histórica -, mas também subjetivas (...) para interrogarmos o presente e projetarmos o futuro" (LIMEIRA, 2006). A consciência do homem no espaço pela interação e integração, reordena não só as configurações do terreno, mas também, modos de se posicionar e reposicionamentos dos modos de vida.

A paisagem da cidade de Brasília, exemplificada em suas Escalas Bucólica e Residencial, desde os primeiros anos de sua existência, solicita a interação do homem com o espaço. Espaços vazios, são "espaços do possível” (CARERI,2013). Interações coletivas são caracterizadas pelas intervenções que, da política à poesia, reivindicam reconhecimento de existência no espaço da cidade. São manifestações que requalificam a urbe e reafirmam sua vocação para os encontros comunitários, pelo seu desenho urbano. Ações catalisadas por formas urbanas e formas urbanas que incitam ações. Uma cidade imponente pelo seu desenho, o que "implica seguir as linhas que fogem por todos os lados e que afirmam a invenção de existências singulares para além dos espaços dados ou dos dados sobre o espaço" (DELEUZE apud GODOY, 2013), ou seja, uma cidade flúida, reinventada constantemente, em "existências que se explicam, desdobram por meio de uma ética e uma estética e que, confrontando as condições da experiência possível, afirma a vida em sua heterogeneidade como condição da experiência real" (DELEUZE apud GODOY, 2013). Se os espaços da cidade 
demonstram vocação para os encontros comunitários, demonstram também a mesma vocação para os encontros solitários, quando a solidão nada mais é que o encontro com si mesmo.

Experimentar a cidade incita o descongelamento das imagens reconhecíveis imperantes. Mais que um monumento arquitetônico, um ipê amarelo, um cobogó ou um piquinique em seus jardins caracterizam melhor a cidade e é por isso que quase como um movimento subversivo, aparecem a cada dia, novos retratos que circulam nos meios alternativos de cultura e mostram uma Brasília mais real, mais reconhecível, que desperta novas iconografias, mais próxima de quem a vivencia e não apenas a observa. São imagens do cotidiano, dos detalhes e das particularidades da cidade, como seu projeto urbano:

Figura 120: Novas iconografias de Brasília

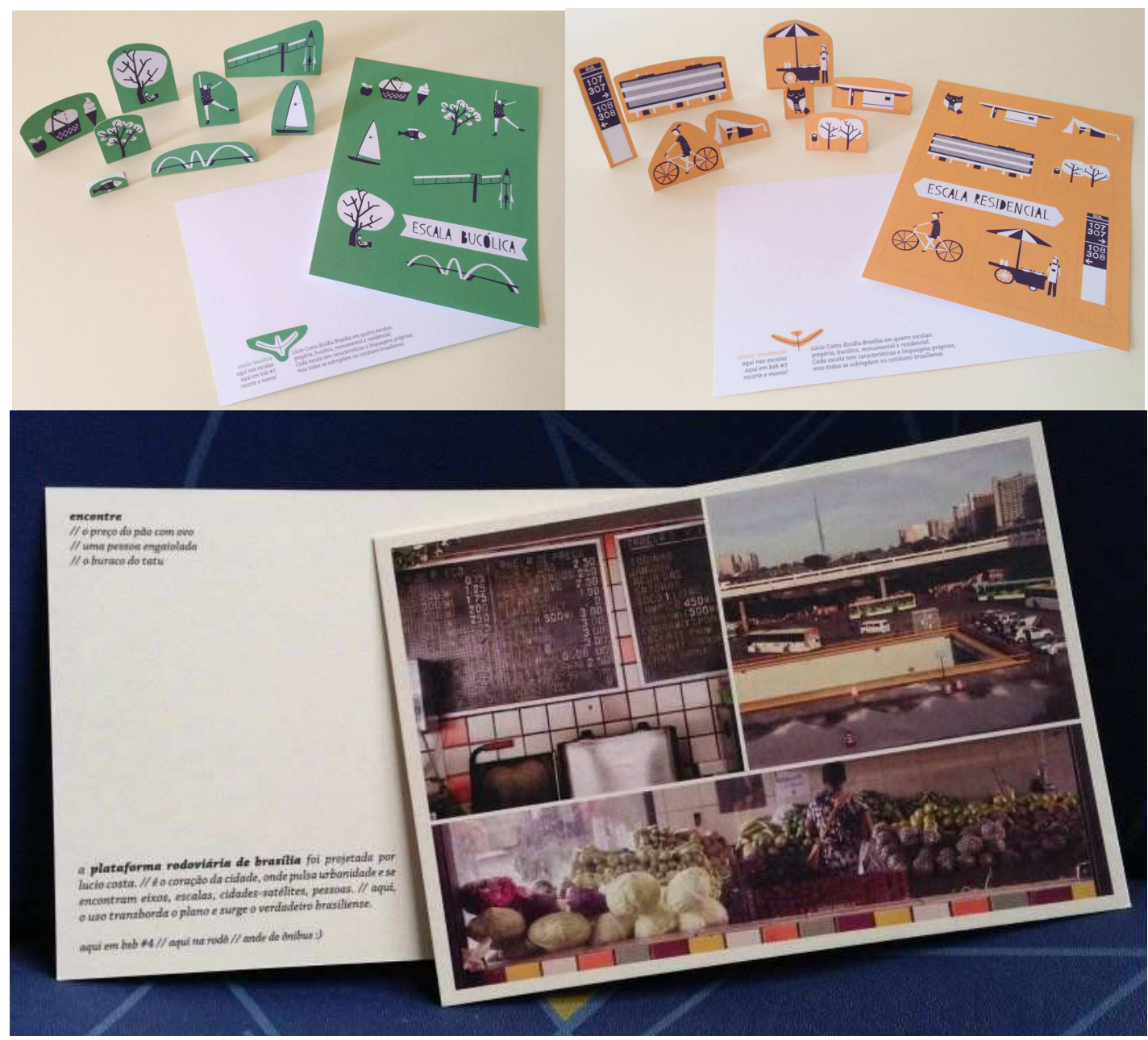

Fonte: https://www.facebook.com/aquiembsb/photos_stream (2014) 
Realidades elaboradas pela vivência. E esta vivência experimentada pelos habitantes da cidade quando assumem um olhar de turista, um olhar mais atento, olhar que estendido aos visitantes proporciona uma maior aproximação do que vem a ser a cidade não só enquanto realidade, mas possibilidades.

Estas possibilidades foram trabalhadas pelo projeto "Brasília Bucólica: A experiência do caminhar" quando a prática da caminhada apresentou perspectivas de compreensão do espaço e possíveis interpretações. O projeto trouxe relatos estéticos expostos por imagens e textos de quem realizou essa experiência. As percepções adquiridas por percursos a pé, traduzem a teoria da caminhada que pelo tempo desacelerado, pelo olhar atento, pela liberdade suspensiva, pela entrega do corpo no espaço transforma simultaneamente os significados da própria existência do caminhante quanto da cidade, demonstram que na experiência do olhar pela caminhada o mundo se desenha, o espaço surge e a paisagem se desvela. É trabalhado um novo olhar sobre a cidade, no entendimento de que esta, por sua paisagem, é reconstrução constante do olhar, quando este é atento, cuidadoso e advindo da experiência de percepção do espaço pela sua vivência.

Assim, esta dissertação buscou transcender a superficialidade das definições impostas, das imagens estratificadas, das teorias determinantes de quem conhece as leis e ordens das construções urbanas como um pesquisador que, de costas para a janela não cogita o abandono da sua escrivaninha e que não percebe que seu objeto de estudo é flexível, mutante, mutável, transformado e transformante, que precisa ser olhado com os olhos da experiência prática, da vivência das inter-relações. Olhos que nos conduzem às sensações e que, portanto, estão localizados senão em nossos pés. 


\section{X- REFERENCIAIS BIBLIOGRÁFICOS}

ALTMAN, Fábio. Era um rabisco e pulsava. Veja. Especial Brasília, 50 anos. 2010. Disponível em: http://veja.abril.com.br/especiais/brasilia/era-rabisco-pulsava-p-072.html

ALVES, Kerkey Santos. Notas sobre a relação espaço-identidade no turismo. In COSTA, Everaldo Batista da Costa, BRUSADIN,Leandro Benedini, PIRES, Maria do Carmo (org) . Valor Patrimonial e turismo: limiar entre história, território e poder. São Paulo. Editora Outras Expressões, 2012.

BACHELARD, Gaston. A poética do Espaço. São Paulo. Martins Fontes, 1989

BARBIEIRI, Renato. Cidades Inventadas. Documentário: The History Channel, 2010.

BENEVOLO, Leonardo. História da Cidade. São Paulo: Perspectiva, 2012

BETTANINI, Tonino. Espaço e Ciências Humanas. Rio de Janeiro.Paz e Terra, 1982

BÍLÁ, Gabriela. O Novo Guia de Brasília. Brasília: Ed.do Autor, 2014.

BOFF, Leonardo. Sustentabilidade: tentativa de definição. Leonardoboff.com. Disponível em https://leonardoboff.wordpress.com/2012/01/15/sustentabilidade-tentativa-de-definicao/

BONOMI, Andréa. Fenomenologia e Estruturalismo. São Paulo. Editora Perspectiva S.A., 1974

BORGES, Neto. Sob o signo da poesia. Documentário. Olho Filmes. Brasil. 2011.

BOURDIEU, Pierre. O poder simbólico. Rio de Janeiro, Bertrand, 2011.

O capital social - notas provisórias. CATANI, A. \& NOGUEIRA, M. A. (Orgs.) Escritos de Educação. Petrópolis: Vozes, 1998.

BRAGA, Milton. O concurso de Brasília: sete projetos para uma capital. S.P.:Cosac\&Naify, 2010.

BRAZILIENSE, Correio. Entre Cobogós e Utopias. Matéria de jornal impresso do dia 02/06/2013

CALDEIRA, Junia. A praça brasileira: trajetória de um espaço urbano: origem e modernidade. 2007. 423 f. Tese (Doutorado)-Departamento de História, IFCH, Universidade Estadual de Campinas, Campinas, 2007. 
CALVINO, Ítalo. As cidades invisíveis. São Paulo: Companhia das Letras, 1990.

Marcovaldo ou As estações na cidade. São Paulo: Companhia das Letras, 1994.

CANEZ, Anna Paula. SEGAWA, Hugo. Brasília: utopia que Lucio Costa inventou. Arquitextos. 125 ano 11, out 2010. Disponível em http://www.vitruvius.com.br/revistas/read/arquitextos/11.125/3629. Acesso em: 25/07/2013

CARDOSO, Janaina Maquiavel. Cidades em Movimento. Artigo do Correio Braziliense (cadero Pensar e Agir) de 27 de dezembro de 2014.

CARERI, Fracesco. Walkscapes: o caminhar como prática estética. I.ed. São Paulo: Editora G. Gili,2013.

CAVAlCAnti, Lauro. Além da Arquitetura: o Pensamento de Lucio Costas. In Catálogo da Exposição Lucio Costa/ Projeto Casa de Lucio Costa. 2010.

CHOAY, Françoise. O urbanismo: utopias e realidades, uma antologia. São Paulo: Perspectiva, 2005.

COSTA, Casa de Lucio. Lucio Costa - Arquiteto - Catálogo de exposição. Rio de Janeiro: Editora Casa de Lucio Costa, 2010.

COSTA, Lucio. Plano Piloto. IPHAN. http://www.guiadebrasilia.com.br/historico/revisitada-d.htm. Acessado em 20/02/2013.

Brasília, a cidade que inventei: Relatório do Plano Piloto de Brasília. GDF, 1991.

Brasília Revisitada. http://portal.iphan.gov.br/portal/baixaFcdAnexo.do?id=280. 1985/1987. Acessado em 22/02/2013

COSTA, Maria Elisa. Com a palavra, Lucio Costa. Rio de Janeiro: Aeroplano, 2001.

COSTA, Graciete Guerra da. Regiões Administrativas do Distrito Federal de 1960 a 2011. Brasília: $\mathrm{UnB}, 2011$.

D'ANGELO, Martha. A modernidade pelo olhar de Walter Benjamin.Estud. av. [online]. 2006, vol.20, n.56, pp. 237-250. ISSN 0103-4014

DELSON, Roberta Marx. Novas Vilas para o Brasil-Colônia. Planejamento Espacial e Social no Século XVI I. Brasìlia: Ed. ALVA-CIORD, 1979. 
DIAS, Karina. Entre a visão e Invisão: Paisagem: por uma experiência da paisagem no cotidiano Brasília: Programa de Pós-Graduação em Arte, Universidade de Brasília, 2010.

Notas sobre paisagem, visão e invisão.

http://www.revistas.ufg.br/index.php/VISUAL/article/view/18075

DIDI-HUBERMAN, Georges. O que vemos o que nos olha. São Paulo: Ed.34, 1998.

GASTAL, Susana. Turista Cidadão: Uma contribuição ao estudo da cidadania no Brasil. Congresso Brasileiro de Ciências da Comunicação - UnB, 2006.

GHIONE, Roberto. Que cidade estamos construindo? Metrópole e sociedade contemporâneas, Vitruvius Revista. 143.01 Cidades do Mundo. Ano 12, junho 2012.

GODOY, Ana. Ecologia e Anarquia. 2008. Disponível em www.nu-sol.org/agora/pdf/anagodoy.pdf . Ultimo acesso em 21/07/2013

GRINSPUM, Ester. Do Desenho. Em Disegno. Desenho. Desígnio/ org. Edith Derdyk. São Paulo: Editora Senac São Paulo, 2007.

GROS, Frédéric. Caminhar, uma filosofia. São Paulo. É Realizações Editora, Livraria e Distribuidora, 2010.

GEHL, JAN. Tamanho e Beleza não são tudo. Entrevista de Gabriela Jimenez à Revista Veja. 29 de Agosto de 2012.

GUIMARÃES, Solange T.L. Valoração de Paisagens: Campos de Visibilidades e de Significâncias. In COSTA, Everaldo Batista da, BRUSADIN, Leandro Benedini, PIRES, Maria do Carmo (org) em Valor Patrimonial e turismo: limiar entre história, território e poder. São Paulo. Editora Outras Expressões, 2012.

HOFFMANN, Bruno. A Capital do sonho. http://www.almanaquebrasil.com.br/curiosidadeshistoria/9312-a-capital-do-sonho.html 19/07/2013 acessado em 21/07/2003

HOLANDA, Sérgio Buarque de. Raízes do Brasil. - 26. ed.- São Paulo: Companhia das Letras, 1995.

JACOBS, Jane. Morte e vida de grandes cidades - $3^{\mathrm{a}}$ ed. - São Paulo: Editora WMF Martins Fontes, 2011 - (Coleção cidades) 
LE CORBUSIER. Precisões sobre um estado presente da arquitetura e do urbanismo. Ferreira Martins. São Paulo: Cosac \& Naify, 2004.

LADRIÈRE, J. A cidade, indutor existencial. In: Vida social e destinação. São Paulo: Convívio, 1979.

LÊ MÉNAHÈZE, Sophie. Hospitalidade ao ar livre . In O livro da Hospitalidade : acolhida do estrangeiro na história e nas culturas. Alain Montandon - São Paulo: Editora Senac São Paulo, 2011.

LEFEBVRE, Henri. Espaço e Política. Editora UFMG. Belo Horizonte, 2008.

LIMEIRA, Maria Margarida Cavalcanti. Cidades Complexas no Século XXI. In Metodologias multidimensionais em ciências humanas / Maria Lucia Rodrigues, Maria Margarida Cavalcanti Limeira (organizadoras). Brasília: Líber Livro Editora, 2006.

LYNCH, Kevin. A Imagem da Cidade - 3ªed. - São Paulo: Editora WMF Martins Fontes, 2011 (Coleção cidades)

MACIEL, Fabiano. A vida é um sopro. Documentário. Estúdio Santa Clara Comunicação. Brasil, 2007.

MASINI, E. F. S. Enfoque fenomenológico de pesquisa em educação. In: FAZENDA, I. (Ed.) Metodologia da pesquisa educacional. São Paulo: Cortez, 1989.

MOESCH, Marutschka Martini. Epistemologia social do Turismo. Tese de doutorado, USP.São Paulo, 2004.

A origem do conhecimento, o lugar da experiência e da razão na gênese do conhecimento do turismo. Artigo extraído da Tese de Doutorado em comunicação, Título Epistemologia Social do Turismo. ECA/USP/SP, 2004.

MONGIN, O. A condição urbana: a cidade na era da globalização. São Paulo: Estação Liberdade, 2009.

MUMFORD, Lewis. La cultura de las ciudades. Emecé Editores. Buenos Aires. 1945

NETTO, Alexandre Panosso. Filosofia doTurismo: teoria e epistemologia. São Paulo: Aleph, 2011.

NIETZSCHE, Friedrich Wilhelm. Humano demasiado humano: um livro para os espíritos livres. São Paulo: Companhia das Letras, 2005.

NÓBREGA, Lara Santina Santos e DIAS, Karina. O Turista Flâneur e o desvelamento do Centro Histórico de João Pessoa: Breves Considerações sobre a prática do turismo. 
http://www.cet.unb.br/portal/images/stories/divulgacao/anptur\%202.pdf

OLIVEIRA, Guilherme Saramago de. Breves Considerações a respeito da fenomenologia e do método fenomenológico, 2008. Campinas.

Artigo disponível em http:// www.funcamp.edu.br/editora/index.php/cadernos/article/view/103

PENNA, José Oswaldo de Meira. Quando mudam as capitais. - Brasília: Senado Federal, Conselho Editorial, 2002.

PONTUAL, Virgínia \& LEITE, Julieta. Da cidade real à cidade digital: a flânerie como uma experiência espacial na metrópole do século XIX e no ciberespaço do século XXI. In: Revista Famecos, n.30, Ago. 2006.

SAINT-EXUPÉRY, Antoine de. O pequeno príncipe. -48.ed. - Rio de Janeiro: Agir,2009.

SANTOS, Milton. A natureza do espaço: técnica e tempo, razão e emoção. São Paulo: Editora da Universidade de São Paulo, 2002.

Metamorfoses do Espaço Habitado: Fundamentos Teóricos e Metodológicos da Geografia. - 6ªed. 2 reimp. - São Paulo: Editora da Universidade de São Paulo, 2014.

. Técnica, Espaço, Tempo: Globalização e Meio Técnico-científico-informacional. - 5. ed., 1 reimp. - São Paulo: Editora da Universidade de São Paulo, 2013.

SCHELLE, Karl Gottlob. A arte de passear. São Paulo: Martins Fontes, 2001.

SENNET, Richard. Carne e Pedra. Rio de Janeiro, BestBolso, 2008.

TAMANINI, L. Fernando. Brasília, memória da construção. Ed. Brasília, 2003

TIBURI, Márcia. Diálogo/ Desenho / Márcia Tiburi, Fernando Chuí. - São Paulo: editora Senac São Paulo, 2010.

THOREAU, Henry David. Andar a pé. 2003 PDF disponível em eBook http://www.ebooksbrasil.org/adobeebook/andarape.pdf. Acesso em 25/07/2013

TUAN, Yi-Fu. Topofilia: um estudo da percepção, atitude e valores do meio ambiente / Yi-Fu Tuan; tradução: Lívia de Oliveira. Londrina: Eduel, 2012.

URRY, John. O olhar do Turista - lazer e viagens nas sociedades contemporâneas. São Paulo: Papirus, 1993. 
VIAJANTE, Tarsila. São Paulo: [s.n], 2008. 160 p. Catálogo de exposição, 19 janeiro - 16 março 2008, Pinacoteca do Estado de São Paulo ; 27 março - 02 junho 2008, MALBA Buenos Aires, Arg.

VIANNA, Bento. Do céu, Brasília. Bendito Brasil, 2014.

VILLASCHI, Juca. Requalificação da cidadania pela interpretação sensorial: direito ao patrimônio. In COSTA Everaldo Batista da, BRUSADIN, Leandro Benedini, PIRES, Maria do Carmo (org) em Valor Patrimonial e turismo: limiar entre história, território e poder. São Paulo. Editora Outras Expressões, 2012.

WESELY, Michael. Arquivo Brasília: Lina Kim e Michael Wesely. São Paulo. Cosac Naify, 2010.

WHITE, Edmund. O flâneur: um passeio pelos paradoxos de Paris. São Paulo: Companhia das Letras, 2001, p. 48.

WRIGHT, Susan. Georgia O'Keeffe - An Eternal Spirit. Todtri Productions Limited, 1996. 
ANEXOS

135 


\section{GOVERNO DO DISTRITO FEDERAL DECRETO N 10.829, DE 14 DE OUTUBRO DE 1987}

Regulamenta o art. 38 da Lei $\mathrm{n}^{\circ} 3.751$ de 13 de abril de 1960, no que se refere à preservação da concepção urbanística de Brasília.

O GOVERNADOR DO DISTRITO FEDERAL, no uso das atribuições que lhe confere o art. 20, II, da Lei $\mathrm{n}^{\circ}-3.751$, de 13 de abril de 1960; considerando que o Art. 38 da Lei $\mathrm{n}^{\circ}$ 3.751, de 13 de abril de 1960, preserva o Plano Piloto de Brasília, tal como apresentado por Lúcio Costa; considerando que, para a exata aplicação do art. 38, da Lei $\mathrm{n}^{\circ} 3.751$, de 13 de abril de 1960, faz-se oportuna à edição de norma regulamentar que explicite o conceito do bem cultural por ela protegido, DECRETA:

\section{CAPÍTULO I}

\section{DO PLANO PILOTO E SUA CONCEPÇAO URBANÍSTICA}

Art. $1^{\circ}$-Para efeito de aplicação da Lei n ${ }^{\circ} 3.751$, de 13 de abril de 1960, entende-se por Plano Piloto de Brasília a concepção urbana da cidade, conforme definida na planta em escala 1/20.000 e no Memorial Descritivo e respectivas ilustrações que constituem o projeto de autoria do Arquiteto Lúcio Costa, escolhido como vencedor pelo júri internacional do concurso para a construção da nova Capital do Brasil.

$\S 1^{\circ}$-A realidade físico-territorial corresponde ao Plano Piloto referido no caput deste Artigo, deve ser entendido como o conjunto urbano construído em decorrência daquele projeto e cujas complementações, preservação e eventual expansão devem obedecer às recomendações expressas no texto intitulado Brasília Revisitada e respectiva planta em escala 1/25.000, e que constituem os anexos I e II deste Decreto.

$\S 2^{\circ}$-A área a que se refere o caput deste Artigo é delimitada a Leste pela orla do Lago Paranoá, a Oeste pela Estrada Parque Industrial e Abastecimento -EPIA; ao Sul pelo Córrego Vicente Pires e ao Norte pelo Córrego Bananal, considerada entorno direito dos dois eixos que estruturam o Plano Piloto.

\section{CAPÍTULO II}

\section{DA ESCALA MONUMENTAL}

Art. $3^{\circ}$-A escala monumental, concebida para conferir à cidade a marca de efetiva capital do País, está configurado no Eixo Monumental, desde a Praça dos Três Poderes até a Praça do Buriti e, para a sua preservação, obedecerão às seguintes disposições:

I -A Praça dos Três Poderes fica preservada tal como se encontra nesta data, no que diz respeito aos Palácios do Planalto e do Supremo Tribunal Federal, ao Congresso Nacional, bem como aos elementos escultórios que a complementam, inclusive o Panteão, a Pira e Monumento ao Fogo Simbólico, construídos fora da Praça, mas que se constituem parte integrante dela; 
II -Também ficam incluídas para preservação as sedes vizinhas dos Palácios do Itamaraty e da Justiça, referências integradas da Arquitetura de Oscar Niemeyer na Praça dos Três Poderes;

III -Os terrenos do canteiro central verde são considerados non-aedificandi nos trechos compreendidos entre o Congresso Nacional e a Plataforma Rodoviária e, entre esta e a Torre de Televisão e, no Trecho não ocupado entre a Torre de Televisão e a Praça do Buriti;

IV -A Esplanada dos Ministérios, ao Sul e ao Norte do canteiro central, à exceção da Catedral de Brasília, será de uso exclusivo dos Ministérios Federais, sendo, entretanto, admitida tal como consta do Plano Piloto, edificação de acréscimos com um pavimento em nível de mezanino e sobre pilotis, para instalação de pequeno comércio e serviços de apoio aos servidores, no espaço compreendido entre o meio dos blocos e a escada externa posterior;

V -As áreas compreendidas entre a Esplanada dos Ministérios e a Plataforma Rodoviária, ao Sul e ao Norte do canteiro central, e que constituem os Setores Culturais Sul e Norte, destinam-se a construções públicas de caráter cultural. Parágrafo único Quaisquer modificações físicas nas áreas preservadas nos incisos I e II deste artigo serão submetidas à aprovação do CAUMA.

\section{CAPÍTULO III}

\section{DA ESCALA RESIDENCIAL}

Art. $4^{\circ}$-A escala residencial, proporcionando uma nova maneira de viver, própria de Brasília, está configurada ao longo das alas Sul e Norte do Eixo Rodoviário Residencial e, para a sua preservação, obedecerão às seguintes disposições:

I -Cada Superquadra, nas alas Sul e Norte, contará com um único acesso para transporte de automóvel e será cercada, em todo o seu perímetro, por faixa de 20,00m (vinte metros) de largura com densa arborização;

II -Nas duas alas, Sul e Norte, nas sequências de Superquadras numeradas de 102 a 116, de 202 a 216 e de 302 a 316, as unidades de habitações conjuntas terão seis (seis) pavimentos, sendo edificadas sobre piso térreo em pilotis, livre de quaisquer construções que não se destinem a acessos e portarias;

III -Nas duas alas, Sul e Norte, nas sequências de Superquadras duplas numeradas de 402 a 416, as unidades de habitações conjuntas terão três pavimentos, edificados sobre pisos térreos em pilotis livres de quaisquer construções que não se destinem a acessos e portarias;

IV -Em todas as Superquadras, nas alas Sul e Norte, a taxa máxima de ocupação para a totalidade das unidades de habitação conjunta é de $15 \%$ (quinze por cento) da área do terreno compreendido pelo perímetro externo da faixa verde;

V -Em todas as Superquadras só será permitida a venda das projeções dos edifícios, permanecendo de domínio público a área remanescente; 
VI -Além das unidades de habitações conjuntas, serão previstas e permitidas pequenas edificações de uso comunitário;

VII -Na ala Sul, os comércios locais correspondentes a cada Superquadra deverão sempre ser edificados na situação em que se encontram na data da edição do presente Decreto;

VIII -As áreas entre as Superquadras, nas alas Sul e Norte, denominadas Entrequadras, destinam-se a edificações para atividades de uso comum e de âmbito adequado às áreas de vizinhança próximas, como: ensino, esporte, recreação e atividades culturais e religiosas.

Art. $5^{\circ}$-O sistema viário; que serve às Superquadras, ,manterá os acessos existentes e as interrupções nas vias L-1 e W-1, conforme se verifica na ala Sul, devendo-se ao mesmo obedecer na ala Norte.

Art. $6^{\circ}$-Nos setores de Habitação Individual Sul e Norte, só serão admitidas edificações para uso residencial unifamiliar, bem como comércio local e equipamentos de uso comunitário, nos termos em que se configura a escala residencial neste capítulo.

\section{CAPÍTULO IV}

\section{DA ESCALA GREGÁRIA}

Art. $7^{\circ}$-A escala gregária com que foi concebido o centro de Brasília, em torno da intersecção dos eixos monumental e rodoviário, fica configurada na Plataforma Rodoviária e nos setores de Diversões, Comerciais, Bancários, Hoteleiros, Médicohospitalares, de Autarquia e de Rádio e Televisão Sul e Norte.

Art. $8^{\circ}$-Para a preservação da escala gregária referida no Artigo anterior, obedecerão às seguintes disposiçõos;

I -A Plataforma Rodoviária será preservada em sua integridade estrutural e arquitetônica original, incluindo-se, nessa proteção, suas praças atualmente implantadas defronte aos setores de Diversões Sul e Norte;

II -Os setores de Diversões Sul e Norte serão mantidos com a atual cota máxima de coroamento, servindo as respectivas fachadas voltadas para a Plataforma Rodoviária, em toda a altura de campo livre, para instalação de painéis luminosos de reclame, permitindo-se o uso misto de cinemas, teatros e casas de espetáculos, bem como restaurantes, cafés, bares, comércio de varejo e outros que propiciem o convívio público;

III -Nos demais setores referidos no artigo anterior o gabarito não será uniforme, sendo que nenhuma edificação poderá ultrapassar a cota máxima de $65,00 \mathrm{~m}$ (sessenta e cinco metros), sendo permitidos os usos indicados pela denominação dos setores de forma diversificada, ainda que se mantenham as atividades predominantes Preconizadas pelo Memorial do Plano Piloto. 


\section{CAPÍTULO V}

\section{DA ESCALA BUCÓLICA}

Art. $9^{\circ}$-A escala bucólica, que confere à Brasília o caráter de cidade-parque, configurada em todas as áreas livres, contíguas a terrenos atualmente edificados ou institucionalmente previstos para edificação e destinadas à preservação paisagística e ao lazer, será preservada. Observando-se as disposições dos Artigos subsequentes.

Art. 10 -São consideradas áreas non-aedificandi todos os terrenos contidos no perímetro descrito nos parágrafos $1^{\circ}$ e $2^{\circ}$ do artigo $1^{\circ}$ deste Decreto que não estejam edificados ou institucionalmente destinados à edificação, nos termos da legislação vigente, à exceção daqueles onde é prevista expansão predominante residencial em Brasília Revisitada.

$\S 1^{\circ}$-Nas áreas referidas no caput deste Artigo onde prevalece à cobertura vegetal do cerrado nativo, esta será preservada e as demais serão arborizadas na forma de bosques, com particular ênfase ao plantio de massas de araucária, no entorno direto da Praça dos Três Poderes.

$\S 2^{\circ}$-Nas áreas non-aedificandi poderão ser permitidas instalações públicas de pequeno porte que venham a ser consideradas necessárias, desde que aprovadas pelo CAUMA.

Art. 11 -Será mantido o acesso público à orla do Lago em todo o seu perímetro, à exceção dos terrenos, inscritos em Cartório de Registro de Imóveis, com acesso privativo à água.

\section{CAPÍTULO VI}

\section{DAS ÁREAS JÁ OCUPADAS NO ENTORNO DIRETO DOS DOIS EIXOS}

Art. 12 -Com o objetivo de assegurar a permanência, no tempo, da presença urbana conjunta, das quatro escalas referidas nos Capítulos II, III, IV e V deste Decreto, em todas as áreas já ocupadas no entorno dos dois eixos e contidas no perímetro delimitado nos Parágrafos $1^{\circ}$ e $2^{\circ}$ do art. $1^{\circ}$ deste Decreto, ficam mantidos os critérios de ocupação aplicados pela administração nessa data, sendo que, nos terrenos destinados à recreação e esporte, nenhuma edificação poderá ultrapassar a cota máxima do coroamento de 7,00m (sete metros), à exceção dos ginásios cobertos, e nos terrenos destinados a hotéis de turismo, onde nenhuma edificação poderá ultrapassar a Cota máxima de coroamento de $12,00 \mathrm{~m}$ (doze metros).

$\S 1^{\circ}$-Nos terrenos contíguos à Esplanada dos Ministérios só serão admitidas as edificações necessárias à expansão dos serviços diretamente vinculados aos Ministérios do Governo Federal, não podendo ser ultrapassada a cota máxima do coroamento dos anexos existentes.

$\S 2^{\circ}$-Só serão admitidos os remanejamentos decorrentes das recomendações contidas em Brasília Revisitada. 


\section{CAPÍTULO VII}

\section{DAS DISPOSIÇÕES GERAIS}

Art. 13 -Para efeito de aplicação do disposto neste Decreto são considerados setores institucionalizados todas as partes da cidade de Brasília referidas no Memorial do Plano Piloto ou criadas pela administração durante a implantação da capital e consagrada pelo uso popular.

Art. 14 -O Governador do Distrito Federal proporá a edição de leis que venham a dispor sobre o uso e ocupação do solo em todo o território do Distrito Federal.

Art. 15 -As proposições contidas em Brasília Revisitada deverão ser objeto de lei especial, em particular no que diz respeito à implantação de Quadras Econômicas, ao longo das vias de ligação entre Brasília e as cidades satélites.

Art. 16 -Este Decreto entra em vigor na data de sua publicação, revogadas as disposições em contrário. 


\section{L- Brasília revisitada - Lúcio Costa}

$1985 / 87$

Complementação, Preservação, Adensamento e Expansão urbana

Agradeço ao Governador José Aparecido de Oliveira bem como ao seu Secretário de Viação e Obras Carlos Magalhães por esta oportunidade de ainda fazer algumas ponderações.

Brasília vive hoje um momento decisivo. Nos trinta anos decorridos desde a apresentação do plano-piloto ao juri internacional que escolheria a proposta a ser implantada (IO/III/57) a cidade consolidou-se, de fato, como capital definitiva do país.

Vendo Brasília atualmente, o que surpreende, mais que as alterações, é exatamente a semelhança entre o que existe e a concepção original.

É evidente que uma cidade inaugurada há pouco mais de 25 anos está no começo de sua existência, passada a fase de consolidação a vitalidade urbana é manifesta e crescente, sobretudo agora, com o restabelecimento do poder civil que a gerou - Brasília preenche suas áreas ainda desocupadas e quer se expandir.

Não menos evidente é o fato de que - por todas as razões - a capital é histórica de nascença, o que não apenas justifica mas exije que se preserve, para as gerações futuras, as características fundamentais que a singularizam.

É exatamente na concomitância destas duas contingências que reside a peculiaridade do momento crucial que Brasília hoje atravessa: de um lado, como crescer assegurando a permanência do testemunho da proposta original, de outro, como preservá-la sem cortar o impulso vital inerente a uma cidade tão jovem.

"A liberação do acesso ao concurso reduziu de certo modo a consulta àquilo que de fato importa, ou seja, a concepção urbanística da cidade propriamente dita, porque esta não será, no caso, uma decorrência do planejamento regional, mas a causa dele, a sua fundação é que dará ensejo ao ulterior desenvolvimento planejado da região. Trata-se de um ato deliberado de posse, de um gesto de sentido ainda desbravador nos moldes da tradição colonial. E o que se indaga é como, no entender de cada concorrente, uma tal cidade deve ser concebida."(introdução à memória descritiva do plano-piloto)

Assim, o plano-piloto (como de resto as outras propostas apresentadas) foi, na realidade, uma concepção já traduzida em termos de projeto urbano, e não apenas uma definição preliminar de partido e diretrizes gerais relativas a uso e ocupação do solo, e isto porque o objetivo era a transferência da capital - e não a elaboracão de projeto - em 3 anos.

"Se a sugestão é válida, estes dados, conquanto sumários na sua aparência, já serão suficientes, pois revelarão que apesar da espontaneidade original, ela foi, depois, intensamente pensada e resolvida."(memória descritiva do plano piloto. 


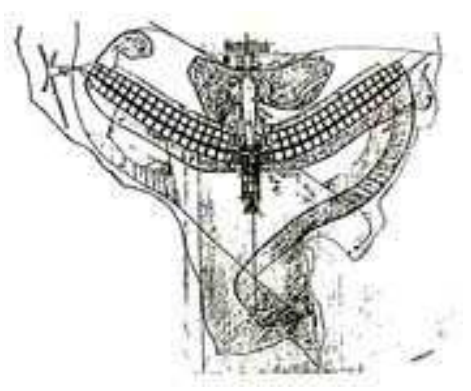

\section{CARACTERÍSTICAS FUNDAMENTAIS DO PLANO-PILOTO}

\section{1 - A interação de quatro escalas urbanas}

A concepção urbana de Brasília se traduz em quatro escalas distintas: a monumental, a residencial, a gregária e a bucólica.

A presença da escala monumental - "não no sentido da ostentação, mas no sentido da expressão palpável, por assim dizer, consciente daquilo que vale e significa" - conferiu à cidade nascente, desde seus primórdios, a marca inelutável de efetiva capital do país.

A escala residencial, com a proposta inovadora da Superquadra, a serenidade urbana assegurada pelo gabarito uniforme de seis pavimentos, o chão livre e accessível a todos através do uso generalizado dos pilotis e o franco predomínio do verde, trouxe consigo o embrião de uma nova maneira de viver, própria de Brasília e inteiramente diversa da das demais cidades brasileiras.

A escala gregária, prevista para o centro da cidade - até hoje ainda em grande parte desocupado - teve a intenção de criar um espaço urbano mais densamente utilizado e propício ao encontro.

As extensas áreas livres, a serem densamente arborizadas ou guardando a cobertura vegetal nativa, diretamente contígua a áreas edificadas, marcam a presença da escala bocólica.

A escala monumental comanda o eixo retilíneo - Eixo Monumental - e foi introduzida através da aplicação da "técnica milenar dos terraplenos "(Praça dos Três Poderes, Esplanada dos Ministérios), da disposição disciplinada porém rica das massas edificadas, das referências verticais do Congresso Nacional e da Torre de Televisão e do canteiro central gramado e livre da ocupação que atravessa a cidade do nascente ao poente.

As Superquadras residenciais, intercaladas pelas Entrequadras (comércio local, recreio, equipamentos de uso comum) se sucedem, regular e linearmente dispostas ao longo dos $6 \mathrm{~km}$ de cada ramo do eixo arqueado - Eixo Rodoviário-Residencial. A escala definida por esta sequência entrosa-se com a escala monumental não apenas pelo gabarito das edificações como pela definição geométrica do território de cada quadra através da arborização densa da faixa verde que a delimita e lhe confere cunho de "pátio interno"urbano.

A escala gregária surge, logicamente, em torno da interseção dos dois eixos, a Plataforma Rodoviária, elemento de vital importância na concepção da cidade e que se tornou, além do mais, o ponto de ligação de Brasília com as cidades satélites. No centro urbano, a densidade de ocupação se previu maior e os gabaritos mais altos, à excessão dos dois Setores de Diversões.

E a intervenção da escala bucólica no rítmo e na harmonia dos espaços urbanos se faz sentir na passagem, sem transição, do ocupado para o não-ocupado - em lugar de muralhas, a cidade se propôs delimitada por áreas livres arborizadas. 


\section{2 - A estrutura viária}

O plano de Brasília teve a expressa intenção de trazer até o centro urbano a fluência de tráfego própria, até então, das rodovias; quem conheceu o que era a situação do trânsito no Rio de Janeiro, por exemplo, na época, entenderá talvez melhor a vontade de desafogo viário, a idéia de se poder atravessar a cidade de ponta a ponta livre de engarrafamentos.

O que permanece incompreensível é até hoje não existir - pelo menos na área urbana - um serviço de ônibus municipal impecável, que se beneficie das facilidades existentes (apenas a título de exemplo: as pistas laterais do Eixo Rodoviário -Residencial - destinadas prioritariamente ao transporte coletivo - tem mão nos dois sentidos; no entanto sua utilização pelos ônibus só se faz numa direção em cada uma delas). Bem como não se ter ainda introduzido o sistema de "transferência" que se impõe para que o passageiro não seja onerado indevidamente.

A estrutura viária da cidade funciona como arcabouço integrador das várias escalas urbanas.

\section{3 - A questão residencial}

O plano-piloto optou por concentrar a população próximo ao centro (Eixo RodoviárioResidencial), através da criação de áreas de vizinhança que só admitem habitação multifamiliar; mas habitação multifamiliar não na forma de apartamentos contruídos em terrenos inadequados e constrangendo os moradores das residências vizinhas, como geralmente ocorre.

A proposta de Brasília mudou a imagem de "morar em apartamento", e isto porque morar em apartamento na Superquadra significa dispor de chão livre e gramados generosos contíguos à "casa" numa escala que um lote individual normal não tem possibilidade de oferecer.

E prevaleceu a idéia de distribuir a ocupação residencial em áreas definidas "a priori" para apartamentos (Superquadras) e para casas isoladas — estas, mais afastadas do centro.

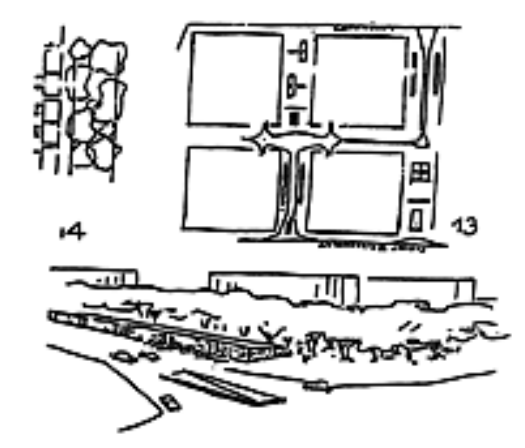

\section{4 - Orla do lago}

O Plano-piloto refuga a imagem tradicional no Brasil da barreira edificada ao longo da água; a orla do lago se pretendeu de livre acesso a todos, apenas privatizada no caso dos clubes. É onde prevalece a escala bucólica.

\section{5 - A importância do paisagismo}

"De uma parte, técnica rodoviária; de outra técnica paisagística de parques e jardins. "(memória descritiva do plano-piloto)

A memória descritiva do plano deixou clara a importância da volumetria paisagística na interação das quatro escalas urbanas da cidade; o canteiro central da Esplanada gramado, as 
cercaduras verdes das Superquadras, a massa densamente arborizada prevista para os Setores Culturais (ainda até hoje desprovidos de vegetação).

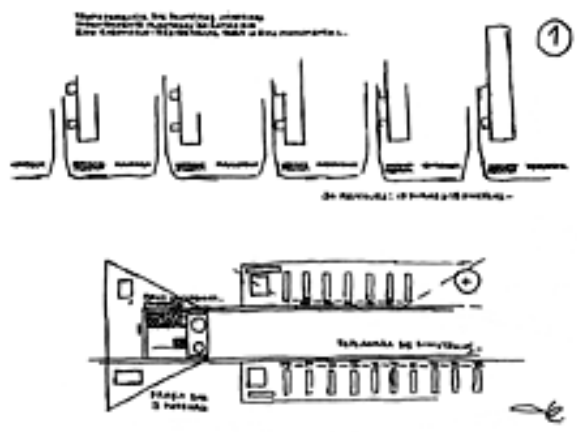

Daí a importância da remoção - enquanto é tempo — das palmeiras imperiais indevidamente plantadas ao longo do Eixo Rodoviário-Residencial para o Eixo Monumental; as razões desta impugnação foram claramente explicadas em dois pareceres anexados a este relato.

São de recomendar, ainda, providências imediatas para a criação de massas compactas de araucária na área abaixo do terrapleno da Praça dos Três Poderes, para que seu verde escuro sirva de fundo e valorize o branco dos palácios, bem como o plantio de renques de pau-rei no entorno direto do edifício do Tribunal de Contas da União - imperdoável aberração no local onde se encontra - a fim de atenuar sua lamentável interferência visual no conjunto da Praça.

\section{6 - A presença do céu.}

Da proposta do plano-piloto resultou a incorporação à cidade do imenso céu do planalto, como parte integrante e omnipresente da própria concepção urbana - os "vazios" são por ele preenchidos; a cidade é deliberadamente aberta aos 360 graus do horizonte que a circunda.

\section{7 - 0 não alastramento suburbano}

A implantação de Brasília, partiu do pressuposto que sua expansão se faria através de cidades satélites, e não da ocupação urbana gradativa das áreas contíguas ao núcleo original. Previase a alternância definida de áreas urbanas e áreas rurais - proposição contrária à idéia do alastramento suburbano extenso e rasteiro.

Assim, a partir do surgimento precoce e improvisado das cidades satélites, prevaleceu até agora a intenção de manter entre estes núcleos e a capital uma larga faixa verde, destinada a uso rural.

Tal abordagem teve como conseqüência positiva a manutenção, ao longo de todos esses anos, da feição original de Brasília. Mas, em contrapartida, a longa distância entre as satélites e o "Plano Piloto "isolou demais a matriz dos dois terços de sua população metropolitana que reside nos núcleos periféricos, além de gerar problemas de custo para o transporte coletivo.

Daí a proposta apresentada no início do atual governo da implantação de Quadras Econômicas - ou Comunitárias - ao longo das vias de ligação entre Brasília e as cidades satélites, sendo mantida a destinação das áreas aos fundos desta orla urbanizada à cultura hortogranjeira.

\section{COMPLEMENTAÇÃO E PRESERVAÇÃO}

Complementar e preservar estas características significa, por conseguinte: 
1 - Proceder ao tombamento do conjunto urbanístico-arquitetônico da Praça dos Três Poderes, incluindo-se os palácios do Itamarati e da Justiça, de vez que constituem sua vinculação arquitetônica com a Esplanada dos Ministérios, cuja perspectiva ficará valorizada com a transferência das palmeiras imperiais.

2 - Manter os gabaritos vigentes nos dois eixos e em seu entorno direto (até os Setores de Grandes Áreas, inclusive), permanecendo não edificáveis as áreas livres diretamente contíguas, e baixa a densidades, com gabaritos igualmente baixos, nas áreas onde já é prevista ocupação entre a cidade e a orla do lago. Isto é fundamental.

Brasília, a capital, deverá manter-se "diferente" de todas as demais cidades do país: não terá apartamentos de moradia em edifícios altos; o gabarito residencial não deverá ultrapassar os seis pavimentos iniciais, sempre soltos do chão. Este será o traço diferenciador - gabarito alto no centro comercial, mas deliberadamente contido nas áreas residenciais, a fim de restabelecer, em ambiente moderno, escala humana mais próxima da nossa vida doméstica e familiar tradicional.

3 - Garantir a estrutura das unidades de vizinhança do Eixo Rodoviário - Residencial, mantendo a entrada única nas Superquadras, a interrupção das vias que Ihes dão acesso - para evitar tráfego de passagem - bem como ocupando devidamente as Entrequadras não comerciais com instalações para esporte e recreio e demais equipamentos de interesse comunitário, sobretudo escolas públicas destinadas ao ensino médio. Proibir a vedação das áreas cobertas de acesso aos prédios (pilotis) e dos parqueamentos - cobertos ou não.

4 - Reexaminar os projetos dos setores centrais, sobretudo os ainda pouco edificados, no sentido de propiciar a efetiva existência da escala gregária - além da Rodoviária e dos dois Setores de Diversões - prevendo percursos contínuos e animados para pedestres e circulação de veículos dentro dos vários quarteirões, cuja ocupação deve, em princípio, voltarse mais para as vias internas do que para as periféricas.

Neste mesmo sentido, não insistir na excessiva setorização de usos no centro urbano - aliás, de um modo geral, nas áreas não residenciais da cidade, excetuando o centro cívico. O que o plano propôs foi apenas a predominância de certos usos, como ocorre naturalmente nas cidades espontâneas.

5 - Providenciar as articulações viárias necessárias para fazer prevalecer na cidade de hoje a mesma clareza e fluência viárias contidas no risco original e, paralelamente, "arrematar" a cidade como um todo (recomendo neste sentido consulta ao trabalho "Brasília 57-85")

6 - Proceder urgentemente às obras de recuperação da Plataforma Rodoviária, que devem ser coordenadas por arquiteto identificado com o projeto original, a ser mantido com rigorosa fidelidade.

7 - Acabar devidamente e manter sempre limpos os logradouros de estar. A começar pelas duas pracinhas da Plataforma Rodoviária - cuidar das plantas, dos bancos e do permanente funcionamento das fontes.

\section{ADENSAMENTO E EXPANSÃO URBANA DO "PLANO PILOTO"}

Uma vez assegurada a proteção do que se pretende preservar, trata-se agora de verificar onde pode convir ocupação - predominantemente residencial - em áreas próximas do "Plano Piloto", ou seja, na bacia do Paranoá, e de que forma tal ocupação deve ser conduzida para integrar-se ao que já existe, na forma e no espírito, ratificando a caracterização de cidade parque - "derramada e concisa" - sugerida como traço urbano diferenciador da capital.

Como já foi mencionado, a primeira proposição neste sentido foi a implantação intermitente de seqüências de Quadras Econômicas ao longo das vias de ligação entre Brasília e as cidades satélites. A proposta visou aproximar de Brasília as populações de menor renda, hoje 
praticamente expulsas da cidade - apesar da intenção do plano original ter sido a oposta - e, ao mesmo tempo, dar também a elas acesso à maneira de viver própria da cidade e introduzida pela superquadra.

Na Quadra Econômica - espécie de "pré-moldado" urbano - a disposição escalonada dos blocos (pilotis e três pavimentos) ao longo da trama viária losangular abre, no interior de cada quadra espaço livre para instalação dos complementos da moradia: lugar para jogos ao ar livre, "áreas de encontro" cobertas para os moços e para os velhos, creche, jardim de infância. A existência deste "quintal comum", com a quase totalidade de chão aberta ao uso de todos, e desses complementos ou "extensões da habitação", ensejando desafogo de tensões, possibilitam convívio doméstico em clima de descontração, mesmo em apartamentos mínimos, além de assegurar boa densidade populacional (cerca de 500 hab/ha). Ao mesmo tempo, essa implantação compacta reduz sensivelmente o custo da infraestrutura urbana uma vez que não compromete grandes superfícies.

Quando, ao longo das vias de ligação, for fisicamente inviável a implantação de Quadras Econômicas, podem ser admitidos núcleos residenciais multifamiliares de outro tipo, desde que com gabarito máximo de pilotis e quatro pavimentos e taxa de ocupação do terreno análogas às das quadras. Em qualquer caso, deve ser reservada faixa contígua à estrada para densa arborização.

Chegando a Brasília propriamente dita, seis áreas comportam ocupação residencial multifamiliar; sendo diretamente vinculadas ao "Plano Piloto" passam, por conseguinte, a interferir no jogo das escalas urbanas.

As duas primeiras ( $\mathrm{A}$ e $\mathrm{B}$ ), na parte oeste da cidade, resultam da distância excessiva entre a Praça Municipal e a Estrada Parque Indústria e Abastecimento decorrente do deslocamento do conjunto urbano em direção ao lago recomendado por Sir William Holford no julgamento do concurso.

A terceira (C), já proposta em 1984, está ligada à intenção de se fixar a Vila Planalto.

A quarta (D), é sugerida pela existência de centros comerciais consolidados na área fronteira.

$\mathrm{E}$ as duas últimas ( $\mathrm{E}$ e $\mathrm{F}$ ) visam abrir perspectiva futura de maior oferta habitacional multifamiliar em áreas que, embora afastadas, vinculam-se ao núcleo original tanto através da presença do lago como pelas duas pontes que se pretende construir (a primeira pessoa a me alertar para tal possibilidade foi o economista Eduardo Sobral, mais de 10 anos atrás). Poderiam ser chamadas "Asas Novas" - Asa Nova Sul e Asa Nova Norte.

$\mathrm{Na}$ implantação dos dois novos bairros a oeste - Oeste Sul e Oeste Norte - foram previstas Quadras Econômicas (pilotis e três pavimentos) para responder à demanda habitacional popular e Superquadras (pilotis e seis pavimentos) para classe média, articuladas entre si por pequenos centros de bairro, com ocupação mais densa, gabaritos mais baixos(dois pavimentos sem pilotis) e uso misto.

A idéia de se implantar um renque de pequenas Quadras $(240 \times 240 \mathrm{~m})$ com gabarito de quatro pavimentos sobre pilotis ao longo da via localizada entre a Vila Planalto e o Palácio da Alvorada (área C) surgiu como única forma realista de, uma vez admitida a fixação da Vila, barrar de fato a gradual expansão de parcelamento em lotes individuais naquela direção, o que interferiria de forma não apenas inadequada mas desastrosa com a escala monumental tão próxima; à primeira vista, a presença destas quadras - Quadras Planalto - pode parecer contraditória com a recomendação de se manterem baixos a densidade e os gabaritos nas áreas onde é admitida ocupação entre o "Plano Piloto" e a orla do lago; na realidade, entretanto, o gabarito uniforme de quatro pavimentos ao longo de cerca de 1.000 metros cria uma dominante horizontal serena que, aliada à presença - indispensável - dos enquadramentos arborizados das Quadras assegura a harmonia do conjunto com seu entorno. 
A ocupação residencial da quarta área (D) só é admissível na forma de renque singelo de pequenas quadras (como as Quadras Planalto, com pilotis e quatro pavimentos) ou de Quadras Econômicas (pilotis e três pavimentos). Em razão da localização desta área, a fim de evitar interferência negativa com o Eixo Rodoviário sul, além do gabarito ser mais baixo, toda a extensão de terreno compreendida entre as novas quadras e o Eixo deve permanecer não edificada ou destinada a usos que impliquem em baixa densidade de ocupação, e sempre cobertas de verde para diluir no arvoredo as construções.

A área $E$ - Asa Nova Sul - sugere ocupação linear, também na forma de pequenas quadras como as Quadras Planalto, com gabarito uniforme de 4 pavimentos sobre pilotis e cercadura arborizada.

Já na área F, muito mais extensa e com topografia peculiar, a ocupação deve prever Quadras Econômicas ou conjuntos geminados para atender à população de menor renda, e considerar a eventual possibilidade de fixacão, em termos adequados, da atual Vila Paranoá, Os demais núcleos de edifícios residenciais devem ser soltos do chão, tendo, no máximo, 4 pavimentos e com gabarito de preferência uniforme para que se mantenha, apesar da ocupação, a serenidade da linha do horizonte, sendo cada conjunto, - desta vez de fato e de saída emoldurado por farta arborização. Os centros de bairro, mais densamente ocupados, devem sempre ter gabaritos mais baixos.

Nessas "Asas Novas", mesmo quando de configuração diversificada, deve também prevalecer a mesma conotação de cidade parque, vale dizer, pilotis livres, predomínio de verde, gabaritos baixos.

Convém ainda destinar parte da Asa Nova Norte a parcelamento em lotes individuais, aproveitando os caprichos da topografia, respeitada a proteção arborizada dos córregos e nascentes. Assim, esta expansão futura atenderá às três faixas de renda.

No intuito de tornar a área das "Mansões" criadas por Israel Pinheiro economicamente mais adequadas, propõe-se admitir nelas uso condominial, onde metade da área original, ou seja, $10.000 \mathrm{~m} 2$, seriam preservados para a casa matriz, podendo a outra metade comportar até 5 novas unidades, todas com entrada comum - independentemente ou não da entrada principal - e constituindo um só conjunto embora sendo, eventualmente, delimitadas por cercas vivas; seria também admissível nessas áreas a instalação de clubes de recreio.

E convém insistir no atendimento à necessidade de habitação popular através da implantação, em grande escala, de Quadras Econômicas, apelando inclusive para as possibilidades da fabricação em série, dentro da tecnologia desenvolvida pelo arquiteto João Filgueiras Lima, e que já conta com fábrica montada em Brasília.

Tudo depende, em última análise, de decisão convicta neste sentido - os meios de fazer acabam aparecendo. Como capital, cabe a Brasília inovar na matéria, mostrando ao país que existe esta alternativa aos tristes aglomerados monótonos de casinholas pseudo-isoladas que proliferam, e se tornaram a imagem melancólica do $\mathrm{BNH}$.

Se computado o custo verdadeiro de cada unidade residencial - incluindo terreno, infraestrutura urbana e construção dos blocos de apartamentos e dos "complementos da moradia", cai por terra a idéia da casa isolada ser a solução economicamente mais viável para o problema da habitação popular. Tanto assim que em países com Cuba e China, onde o caixa é único e o dinheiro pouco, não se cogita de assentamentos residenciais rasteiros, até mesmo em áreas rurais. Além do que, o lote mínimo, com janelas confrontando e seu quintal inexistente porque em geral ocupado por outra família, nada tem a ver com a imagem romântica que se propaga da "casa própria".

Em todo o caso, para atendimento à demanda popular nos moldes tradicionais - lotes individuais - existe o projeto Samambaia, elaborado por técnicos do GDF na administração passada, inclusive com esta intenção. 


\section{CONCLUSÃO}

O "quantum" populacional atingido pela abertura à ocupação dessa novas áreas, pelos adensamentos previstos, pela ocupação residencial multifamiliar nas margens das vias de ligação entre Brasília e as satélites, pelo adensamento controlado destes núcleos e pela implantação da Samambaia, deve ser considerado a população limite para a capital federal, a fim de não desvirtuar a função primeira - político-administrativa - que lhe deu origem. A Brasília não interessa ser grande metrópole.

Como nossa estrutura econômico-social induz à migração de populações carentes para os grandes centros urbanos, é essencial pensar-se desde já no desenvolvimento, em áreas próximas à capital de núcleos industriais capazes de absorver, na medida do possível, essas migrações com efetiva oferta de trabalho. Brasília não é, no caso, uma simples miragem. Cidade fundamentalmente político-administrativa e de prestação de serviços, a demanda de mão de obra, sobretudo não qualificada, é necessariamente menor embora a proximidade do poder central crie a ilusão de facilidades que, de fato, não existem.

Quanto ao escalonamento, no tempo, das implantações aqui sugeridas cabe ao Departamento de Urbanismo da Secretaria de Viação e Obras coordenar os estudos a serem feitos conjuntamente com as demais Secretarias e concessionárias de serviços públicos a fim de definir com segurança o melhor procedimento, bem como as tecnologias a serem utilizadas, tendo em vista o abastecimento de água e energia, o transporte, o saneamento e a preservação do meio ambiente, o controle da poluição do Lago Paranoá e a proteção da área a ser ocupada pela futura represa do São Bartolomeu - integrando, enfim, como um todo, as novas proposições e o planejamento do território do Distrito Federal.

Finalmente, o importante ao se pensar na complementação, na preservação, no adensamento ou na expansão de Brasília é não perder de vista a postura original, é estar-se imbuído de lucidez e sensibilidade no trato dos problemas urbanos; é perceber que coisas maiores e coisas menores têm importância análoga, consideradas cada uma em sua escala; é enfrentar os inúmeros problemas do dia a dia com disposição, firmeza e flexibilidade; é tanto saber dizer não como dizer sim na busca contínua da resposta adequada, - tarefa tantas vezes ingrata e inglória para os técnicos que participam dedicadamente de sucessivas administrações ; é fazer prevalecer o senso comum, fugindo das teorizações acadêmicas e protelatórias, e da improvisação irresponsável. É lembra-se que a cidade foi pensada "para o trabalho ordenado e eficiente, mas ao mesmo tempo cidade viva e aprazível, própria ao devaneio e à especulação intelectual, capaz de tornar-se, com o tempo, além de centro de governo e administração, num foco de cultura dos mais lúcidos e sensíveis do país."

O plano-piloto de Brasília não se propôs visões prospectivas de esperanto tecnológico, nem tampouco resultou de promiscuidade urbanística, ou de elaborada e falsa "espontaneidade".

Brasília é a expressão de um determinado conceito urbanístico, tem filiação certa, não é uma cidade bastarda. O seu "facies" urbano é o de uma cidade inventada que se assumiu na sua singularidade e adquiriu personalidade própria graças à arquitetura de Oscar Niemeyer e à sua gente.

(Extraído do COE - Código de Obras e Edificações - Brasília, DF) 